\title{
Adenovirus-mediated gene transfer of FK506-binding proteins FKBP12.6 and FKBP12 in failing and non-failing rabbit ventricular myocytes
}

\author{
Dissertation \\ zur Erlangung des Doktorgrades \\ der Mathematisch-Naturwissenschaftlichen Fakultäten \\ der Georg-August-Universität zu Göttingen
}

\author{
vorgelegt von \\ Darya Zibrova \\ aus Kremenchug/Ukraine
}

Göttingen 2004 
D7

Referent:

Prof. Dr. Kurt von Figura

Korreferent:

Prof. Dr. Dieter Heineke

Tag der mündlichen Prüfung: $\quad$ 25.06.2004 
LIST OF FIGURES .VI

LIST OF TABLES VII

ABBREVIATIONS VIII

SUMMARY 1

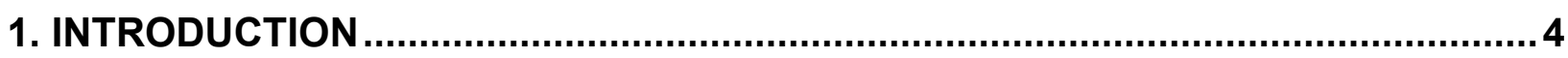

1.1 Key pathways involved in calcium transport in cardiomyocytes. . .4

1.2 $\mathrm{Ca}^{2+}$-release through $\mathrm{SR}$ calcium release channel (ryanodine receptor) as the key event of cardiac E-C coupling 5

1.2.1 Molecular structure of ryanodine receptors 5

1.2.2 The cardiac RyR channel is a regulable macromolecular signalling complex.

1.3 Regulation of RyR channel by FK506-binding proteins (FKBPs) ................... 8

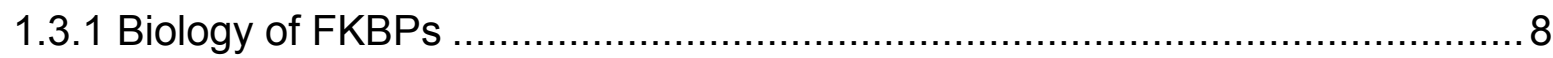

1.3.2 RyRs-FKBPs interaction and its putative physiological functions ..................9

Current concept: RyR1-FKBP12/RyR2-FKBP12.6 association........................ 9

Putative physiological functions of FKBPs with respect to interaction with

RyRs

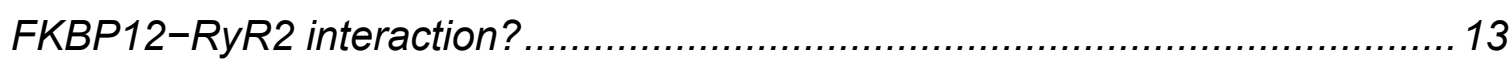

1.3.3 Clinical relevance of FKBPs-RyR2 association/regulation ......................... 15

Alteration of FKBP12.6-RyR2 association in heart failure and PKA-dependent hyperphosphorylation of RyR2 as a putative mechanism of this alteration......... 15 $P K A$ in regulation of FKBP12.6-RyR2 interaction: alternative point of view.......17 Stabilization of cardiac ryanodine receptor via retrieval of its association with FKBP12.6 as a novel therapeutical approach to treatment of heart failure......... 18

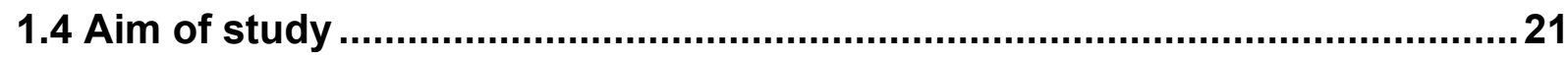

2. MATERIALS

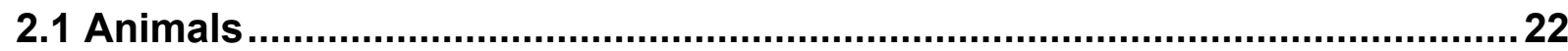

2.2 Bacterial strains, plasmid and adenovirus constructs .................................22

2.3 Oligonucleotides for polymerase chain reaction ..........................................23

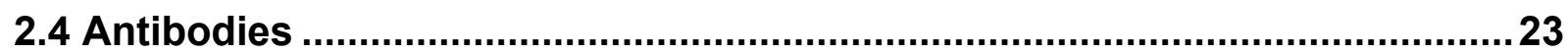

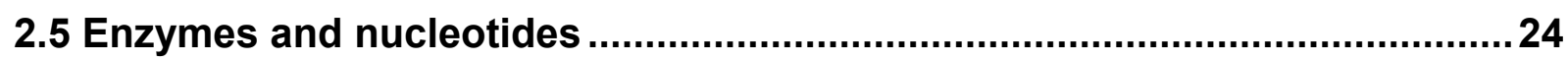

2.6 Detection, purification and synthesis systems (kits) ...................................25

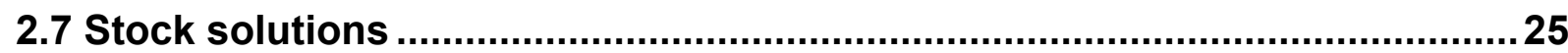




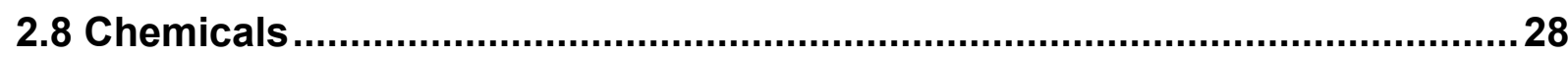

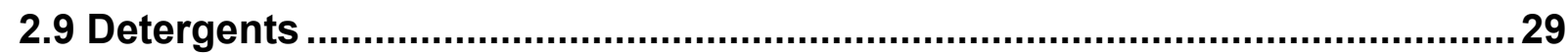

2.10 Proteins, protease inhibitors and protein standards .................................29

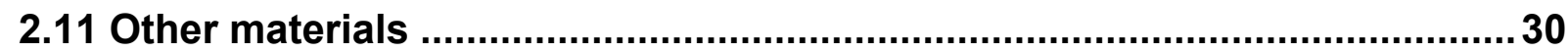

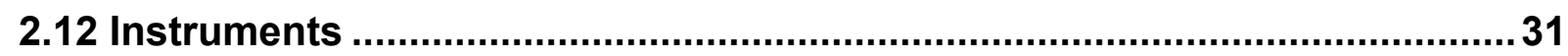

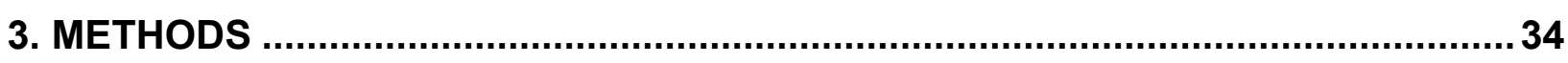

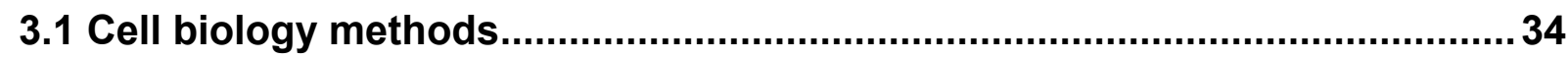

3.1.1 Isolation of rabbit ventricular myocytes ........................................ 34

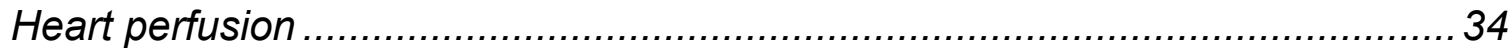

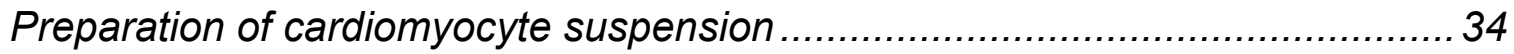

3.1.2 Primary culture of adult rabbit ventricular cardiomyocytes ....................... 37

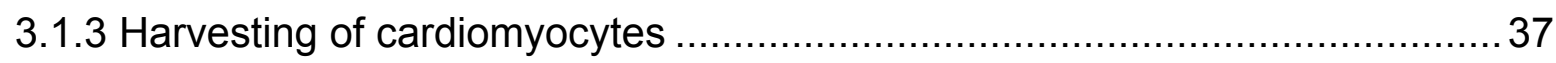

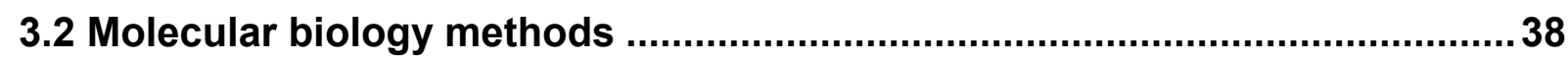

3.2.1 RNA isolation from rabbit cardiomyocytes........................................ 38

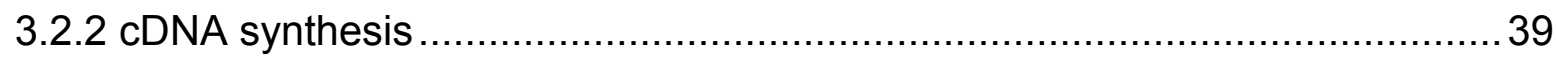

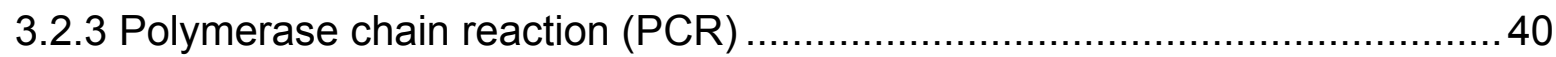

Electrophoresis conditions........................................................... 42

UV detection of DNA, intercalating ethidium bromide ................................ 42

3.2.4 Adenoviral transfection of isolated rabbit ventricular cardiomyocytes ..........43

Calculation of virus quantity taken for transfection ................................... 44

Transfection for verification of transgene expression at $m R N A$ and protein

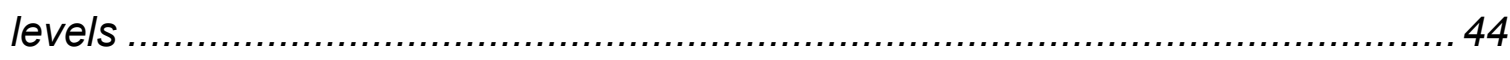

Transfection for cell shortening measurements .......................................... 44

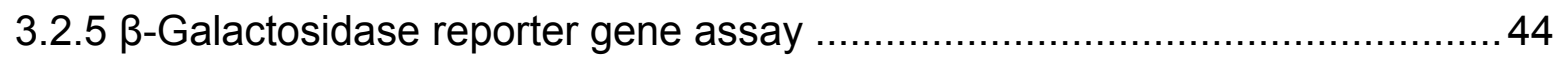

3.3 Single cell shortening measurements by video-edge detection ...................46

3.4. Protein chemistry and immunochemistry methods.................................. 47

3.4.1 Total protein homogenate preparation ............................................ 47

Protein lysate preparation from rabbit ventricular cardiomyocytes ...................47

3.4.2 Preparation of CHAPS-solubilized cardiac membrane fraction (CSMF) ........50

3.4.3 Isolation of ryanodine receptor from rabbit skeletal muscle and human

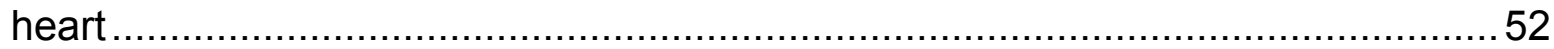

Isolation of heavy SR membranes from rabbit skeletal muscle/human heart .....52

Solubilization of ryanodine receptor and preparation of RyR-enriched

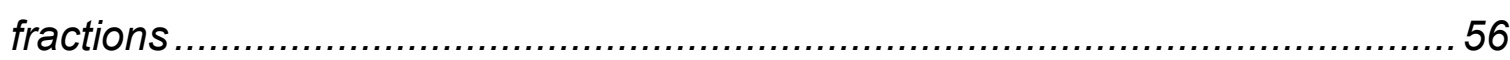

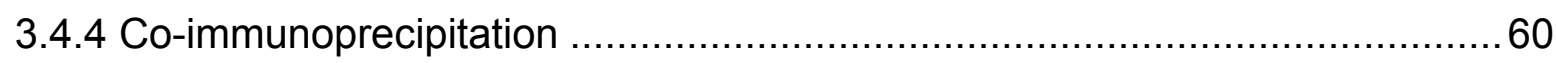


Preparation of cardiac homogenates ................................................. 60

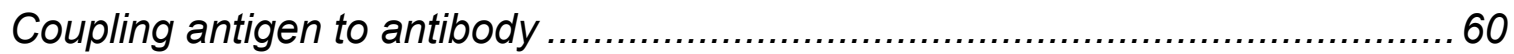

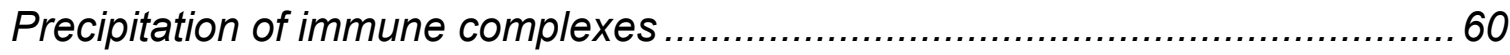

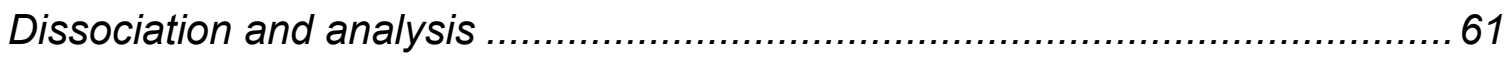

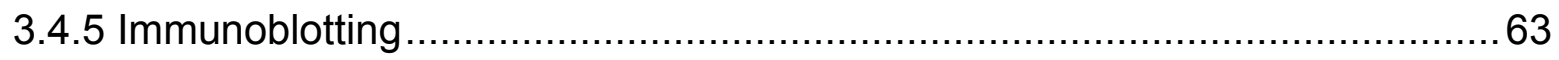

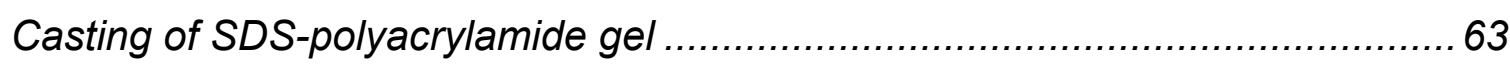

SDS-polyacrylamide gel electrophoresis (SDS-PAGE) and electrophoretic

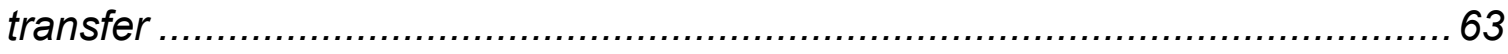

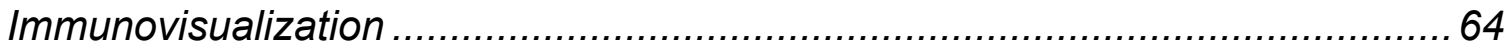

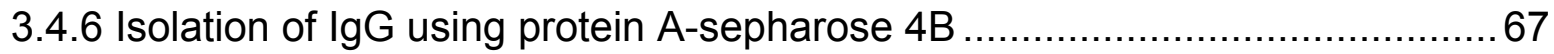

Preparing the medium, packing protein A-sepharose and equilibration.............67

Binding IgG to protein A-sepharose Fast Flow ....................................... 68

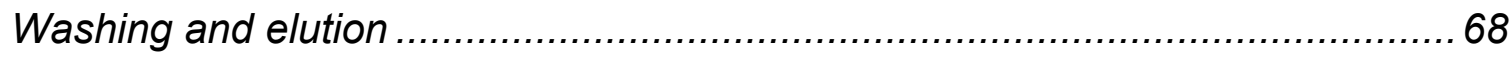

3.4.7 Visualization of proteins with silver staining and Coomassie Blue staining ... 69

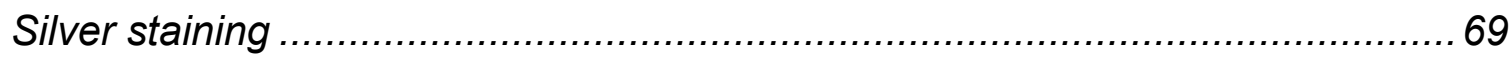

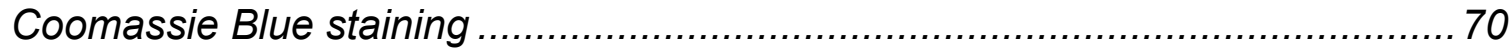

3.4.8 Preparation of proteins for MALDI-TOF mass spectrometry ..................... 71

3.4.8.1 In-gel digest of proteins stained with Coomassie ............................... 71

3.4.8.2 Extraction of peptides from the gel after trypsin digestion ................... 73

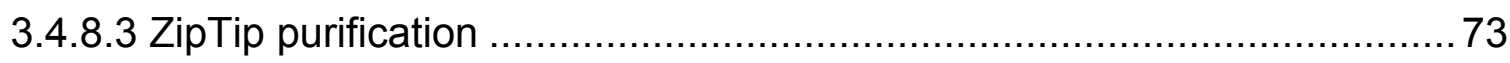

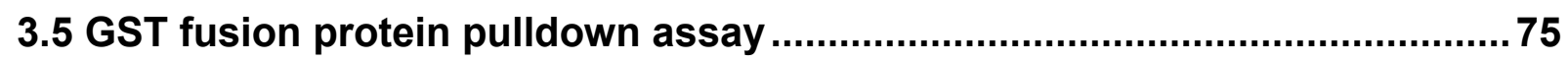

3.5.1 Transformation of bacteria, growth and induction .............................. 75

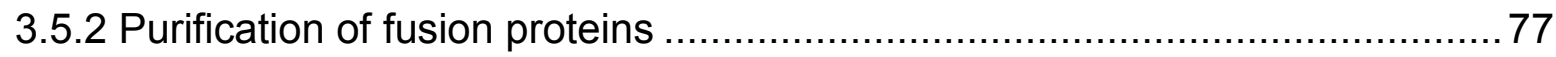

Preparation of cell extract ................................................................... 77

Purification of GST-tagged fusion proteins using Glutathione Sepharose Fast

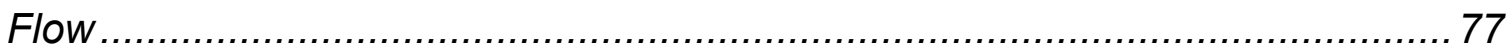

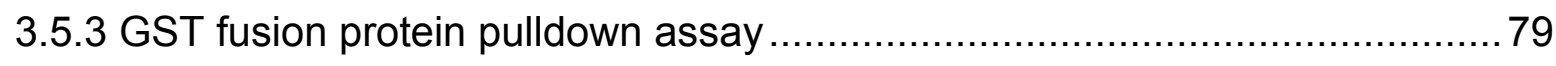

Preparation of cell lysates and cardiac homogenates ................................ 80

Probing of samples containing the target protein and detection of the interacting

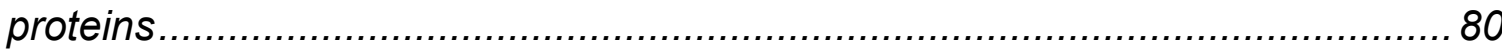

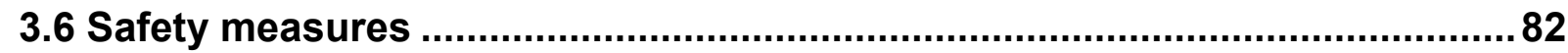

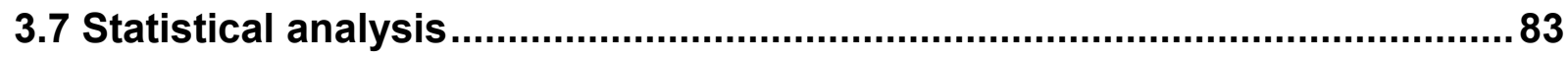

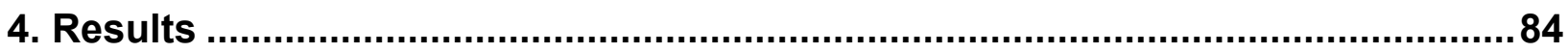

4.1 Verification of virus transfection efficiency and transgene expression levels. 
4.1.1 Verification of virus transfection efficiency in $\beta$-galactosidase reporter gene assay.

4.1.2 Validation of transgene expression at mRNA and protein levels 85

4.2 Contractility measurements of rabbit cardiomyocytes transfected with Ad-FKBP12

4.3 Interaction studies

4.3.1 FKB12.6 but not FKBP12 co-immunoprecipitates with rabbit cardiac ryanodine receptor 88

4.3.2 GST fusion protein pulldown assay .............................................. 90

4.3.2.1 Isolation and identification of RyR1 and RyR2. 91

4.3.2.2 Expression and purification of GST-FKBP12 and GST-FKBP12.6 fusion proteins 94

4.3.2.3 Probing of isolated human cardiac RyR2 and rabbit skeletal muscle RyR1 and detection of FKBP-RyR interaction ....

4.3.2.4 Probing of samples containing rabbit cardiac RyR, detection of interacting proteins and identification of RyR 97

4.3.2.5 Canine RyR2 interacts with FKBP12.6 isoform exclusively 104

\subsection{Overexpression of FKBP12.6 and FKBP12 in cardiomyocytes isolated from} rabbit failing hearts

4.4.1 Characterization of rabbit model of heart failure with respect to RyR2-FKBP12.6 association

4.4.2 Overexpression of FKBP12 and FKBP12.6 in cardiomyocytes isolated from rabbit failing hearts

4.4.3 Contractility measurements of Ad-FKBP12 and Ad-FKBP12.6 transfected cardiomyocytes isolated from rabbit failing hearts and hearts of sham-operated rabbits

4.4.4 Retrieval of FKBP12.6-RyR2 association upon overexpression

4.5 Phosphorylation status of RyR2 in rabbit failing heart 114

5. DISCUSSION. 116

5.1 FKBP12 is relevant to the regulation of cardiac E-C coupling: physiological evidence

5.2 FKBP12 is relevant to the regulation of cardiac E-C coupling: molecular biology evidence.

5.3 Levels of FKBP12.6 associated with RyR2 in rabbit model of heart failure. 
5.4 Restoration of contractile function of failing cardiomyocytes by overexpression of FKBP12 and FKBP12.6 124

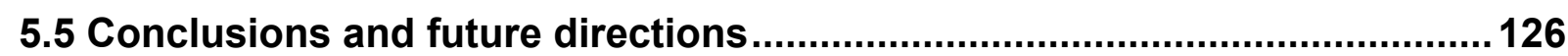

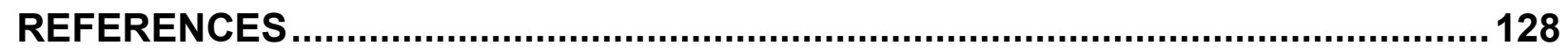




\section{LIST OF FIGURES}

Page

Fig. 1 Schematic representation of key pathways involved in $\mathrm{Ca}^{2+}$ transport in the cardiomyocyte

Fig. 2 Model of SR Ca ${ }^{2+}$-release channel (RyR2) associated with its accessory proteins

Fig. 3 Altered interaction of FKBP12.6 with RyR2 in heart failure

Fig. 4 Major molecular alterations contributing to decrease of $\mathrm{SR} \mathrm{Ca}^{2+}$ content in failing heart

Fig. 5 Schematic representation of the PCR

Fig. 6 Setup for video-edge detection

Fig. 7 Scheme of isolation of RyR channel

Fig. 8 Scheme of GST pulldown assay designed for precipitation of ryanodine receptor based on its specific association with GSTFKBPs

Fig. $9 \quad \beta$-Galactosidase reporter gene assay performed 48 hours post transfection

Fig. 10 Verification of transgene (FKBP12) expression at mRNA and protein levels

Fig. 11 (A) Image of an isolated rabbit ventricular cardiomyocyte. (B) Representative tracing of shortening experiments with transfected cardiomyocytes

Fig. 12 Statistical analysis of cell shortening in Ad-LacZ and Ad-FKBP12 infected myocytes measured 48 hours post transfection

Fig. 13 Association of FKBP12.6 with RyR2 in rabbit CHAPS-solubilized cardiac membrane fraction and rabbit cardiomyocytes

Fig. 14 Fractionation of skeletal muscle SR on a $15-45 \%$ linear sucrose gradient

Fig. 15 Fractionation of cardiac (A) and skeletal muscle (B) CHAPS-solubilized heavy $S R$ on a $10-28 \%$ linear sucrose gradient

Fig. 16 Extract from Mascot Search Results

Fig. 17 Extract from Mascot Search Results

Fig. 18 Coomassie Blue-stained 7.5\% gels depicting different stages of GST fusion proteins expression and purification

Fig. 19 Coomassie Blue-stained gel (A) and Western blot (B) showing different electrophoretic mobilities of GST-FKBP12 and GSTFKBP12.6 recombinant proteins

Fig. 20 Affinity precipitation of RyR2 (A) and RyR1 (B) based on their specific associations with FKBP12.6 and FKBP12, respectively

Fig. 21 Affinity precipitation of RyR2 (A) and RyR1 (B) based on their specific associations with FKBP12 and FKBP12.6, respectively 
Fig. 22 Affinity purification of RyR2 from rabbit cardiomyocyte homogenate using GST-FKBP12 and GST-FKBP12.6

Fig. 23 Affinity purification of RyR2 from human cardiac homogenate using GST-FKBP12 and GST-FKBP12.6

Fig. 24 Protein identification by MALDI-TOF mass spectrometry

Fig. 25 Protein identification by MALDI-TOF mass spectrometry

Fig. 26 Protein identification by MALDI-TOF mass spectrometry

Fig. 27 Protein identification by MALDI-TOF mass spectrometry

Fig. 28 Affinity purification of RyR2 from canine cardiac homogenate based upon its specific association with FKBP12.6

Fig. 29 (A) Protein levels of RyR2 in rabbit failing myocardium and in myocardium from sham-operated rabbits. (B) Statistical comparison of RyR2 levels in myocardium from sham-operated and failing-heart rabbits

Fig. 30 (A) Representative co-immunoprecipitation of RyR2 and FKBP12.6 from cardiac homogenates prepared from hearts of sham-operated and failing-heart rabbits. (B) Quantification of FKBP12.6 associated with RyR2 in sham and failing hearts

Fig. 31 Western blot analysis of Ad-FKBP12.6 (A) and Ad-FKBP12 (B) infected myocytes isolated from rabbit failing heart

Fig. 32 Statistical analysis of fractional shortening of cardiomyocytes isolated from rabbit failing hearts and hearts of sham-operated rabbits

Fig. 33 Statistical analysis of fractional shortening of rabbit failing cardiomyocytes overexpressing FKBP12 and FKBP12.6

Fig. 34 Statistical analysis of fractional shortening of cardiomyocytes, isolated from hearts of sham-operated rabbits, overexpressing FKBP12 and FKBP12.6

Fig. 35 (A) Representative co-immunoprecipitation of RyR2 and FKBP12.6.

(B) Co-immunoprecipitation of RyR2 and FKBP12.6 demonstrating retention of FKBP12.6 on RyR2 in failing cardiomyocytes after transfection with Ad-FKBP12.6

\section{LIST OF TABLES}

Tab. 1 Procedure of silver staining

Tab. 2 Procedure of in-gel digest of proteins stained with Coomassie Blue

Tab. 3 Numerical expression of results obtained in $\beta$-gal reporter gene assay 


\section{ABBREVIATIONS}

$\mathrm{Ab}$

$\mathrm{AcN}$

Ad

AMP

APS

$\beta-A R$

ATP

BCA

BDM

bp

CaMKII

cAMP

CaN

CHAPS

CICR

CMV

CS

CSMF

Dd $\mathrm{H}_{2} \mathrm{O}$

DEPC

DHPR

dNTP

DTT

E. coli

E-C coupling

EDTA

EGTA

FKBP

FS

g

$\beta$-gal

GAPDH
Antibody

Acetonitrile

Adenovirus

Adenosine monophosphate

Ammonium persulfate

$\beta$-Adrenergic receptors

Adenosine triphosphate

Bicinchoninic acid

Butanedione monoxime

Base pair

Calmodulin-dependent protein kinase II

Cyclic adenosine-3',5'-monophosphate

Calcineurin

3-[(3-cholamidopropyl)dimethylammonio]-1-propane

sulphonate

$\mathrm{Ca}^{2+}$-induced $\mathrm{Ca}^{2+}$ release

Cytomegalovirus

Calsequestrin

CHAPS-solubilized cardiac membrane fraction

Double distilled water

Diethylpyrocarbonate

Dihydropyridine receptors

Deoxyribonucleoside triphosphate

Dithiothreitol

Escherichia coli

Excitation-contraction coupling

Ethylendinitrilo-N, N, N', N'-tetra-acetate

Ethylenglycol-bis-(2-aminoethylether)-N, N'-tetra-acetate

FK506-binding protein

Fractional shortening

Gravity

$\beta$-Galactosidase

Glyceraldehyde-3-phosphate dehydrogenase 
GST

HEPES

HPLC

HRP

IDCMP

IgG

$\operatorname{lns} P_{3} R$

IP

IPTG

$\mathrm{kb}$

$\mathrm{kDa}$

LB

MAKAP

MALDI-TOF MS

$\mathrm{MOI}$

MWCO

NF-AT

OD

PBS

PCR

pfu

PKA

PKC

PLB

$\mathrm{P}$ 。

PP

PPlase

rpm

RT

RT-PCR

RyR

SDS

SDS-PAAG

SDS-PAGE
Glutathione S-transferase

2-(4-2-hydroxyethyl)-piperazinyl-1-ethansulfonate

High performance liquid chromatography

Horseradish peroxidase

Idiopathic dilated cardiomyopathy

Immunoglobulin $\mathrm{G}$

Inositol 1,4,5-trisphosphate receptor

Immunoprecipitation

Isopropyl- $\beta$-D-thiogalactoside

Kilobase

Kilodalton

Luria Bertani

Muscle A kinase anchoring protein

Matrix-assisted laser desorption/ionization time-of-flight

mass spectrometry

Multiplicity of infection

Molecular weight cut-off

Nuclear factor of activated T-lymphocytes

Optical density

Phosphate buffered saline

Polymerase chain reaction

Plaque-forming unit

cAMP-dependent protein kinase

$\mathrm{Ca}^{2+}$-dependent protein kinase

Phospholamban

Open probability

Protein phosphatase

Peptidyl-prolyl isomerase

Revolutions per minute

Room temperature

Reverse transcriptase-PCR

Ryanodine receptor

Sodium dodecylsulfate

SDS-polyacrylamide gel

SDS-polyacrylamide gel electrophoresis 
sem

SERCA

SR

SRCRC

TBE

TEMED

TFA

TGF- $\beta$

Tris

UV

WB

X-Gal
Standard error of the mean

Sarcoendoplasmic reticulum $\mathrm{Ca}^{2+}$-ATPase

Sarcoplasmic reticulum

Sarcoplasmic reticulum $\mathrm{Ca}^{2+}$-release channel

Tris borate EDTA buffer

$\mathrm{N}, \mathrm{N}, \mathrm{N}^{\prime}, \mathrm{N}^{\prime}$-tetramethylethylenediamine

Trifluoracetic acid

Transforming growth factor- $\beta$

Tris-(hydroxymethyl)-aminomethane

Ultraviolet

Western blot

(5-Bromo-4-chloro-3-indolyl-[beta]-D-

galactopyranosidecrystal) 


\section{SUMMARY}

Intracellular $\mathrm{Ca}^{2+}$ is a central regulator of cardiac contractility. The key event of excitation-contraction coupling (E-C coupling) in the heart is calcium-induced calcium release $(\mathrm{CICR})$ from the sarcoplasmic reticulum $(\mathrm{SR})$ via $\mathrm{SR} \mathrm{Ca}^{2+}$-release channel known as ryanodine receptor (RyR2).

$\mathrm{Ca}^{2+}$-release from the $\mathrm{SR}$ is a finely regulated process that involves not only the RyR itself, but also a number of accessory proteins interacting with RyR and modulating its activity. Among these proteins are FK506-binding proteins (FKBPs): FKBP12 and its orthologous isoform FKBP12.6.

According to the current concept, FKBP12.6 is tightly and selectively bound to cardiac RyR, whereas FKBP12 is associated with skeletal muscle RyR isoform (RyR1) solely and, consequently, plays a role in RyR regulation only in skeletal muscle. However, several studies provide the evidence that FKBP12 can also regulate cardiac RyR. First, the expression levels of FKBP12 in the heart are considerably higher compared to FKBP12.6. Second, the FKBP12-knockout mouse model showed that FKBP12 modulates both RyR1 and RyR2. Third, the experiments which demonstrated selective association of FKBP12.6 but not FKBP12 with RyR2 were limited to the canine heart and it was not known whether this selectivity of interaction holds true for other species. Thus, the question whether FKBP12 is also involved in the regulation of cardiac RyR is still open.

Therefore, considering the controversy surrounding the given issue, the purpose of the present study was to investigate whether FKBP12 contributes to the regulation of cardiac E-C coupling and to examine a potential interaction of FKBP12 with RyR2.

In heart failure, $\mathrm{Ca}^{2+}$-release from the $\mathrm{SR}$ is disturbed. Defective regulation of RyR2 by FKBP12.6 is thought to be involved in the pathogenesis of heart failure. With this in mind, the second intention behind the present study was to characterize heart failure in a rabbit model with respect to FKBP12.6-RyR2 interaction and to investigate whether FKBP12.6 and/or FKBP12 may represent new molecular target(s) to improve contractile function of failing cardiomyocytes.

To investigate the effect of FKBP12 on cardiac contractility, FKBP12 was overexpressed in isolated rabbit ventricular cardiomyocytes using adenoviral gene transfer. Overexpression of the transgene was verified at mRNA and protein levels using RT-PCR and immunoblotting, respectively. Contractility of isolated rabbit cardiomyocytes was measured by video-edge detection 48 hours after transfection. 
Cardiomyocytes overexpressing FKBP12 showed a significant increase in fractional shortening (by 14\%) compared to LacZ-transfected myocytes which served as a control. It was hypothesized that a modulation of RyR2 activity by FKBP12 via physical association may underlie the effect of FKBP12 overexpression on the contractility of rabbit cardiomyocytes. Direct interaction of FKBP12 with cardiac RyR2 isoform was revealed by GST fusion protein pulldown assay. Human recombinant GST-FKBP12 demonstrated specific interaction with rabbit and human RyR2 with a high affinity and in a FK506-displaceable manner similar to those observed with GST-FKBP12.6. This suggests that RyR2 of these two species is capable of binding to FKBP12 in a functionally relevant manner, since FKBP12 overexpression increases contractility.

To investigate whether FKBP12.6 and/or FKBP12 represent(s) new molecular target(s) to improve contractile function, both FKBP isoforms were overexpressed by adenovirusmediated gene transfer in myocytes isolated from failing hearts of rabbits with tachycardia-induced heart failure. To assess the molecular interaction of FKBP12.6 with RyR2 in the rabbit model, co-immunoprecipitation was performed. The amount of FKBP12.6 associated with RyR2 was decreased by $40 \%$ in failing hearts compared to sham controls. The protein levels of RyR2 were significantly downregulated in failing rabbit hearts compared to sham controls as was assessed by immunoblotting. Phosphorylation status of RyR2 was unchanged in the failing-heart group in comparison to sham controls, as determined by anti-phosphoserine immunoblots. Contractility of isolated rabbit cardiomyocytes was measured by video-edge detection 24 hours after transfection with a multiplicity of viral infection of 100 . Overexpression of the transgene was verified by immunoblotting. Fractional shortening of cardiomyocytes isolated from failing hearts was significantly reduced (by $25 \%$ ) when compared to sham controls. In the failing-heart group, cardiomyocytes overexpressing FKBP12.6 showed a statistically significant increase in fractional shortening in comparison with LacZ transfected cells, indicating partial restoration (by $44 \%$ ) of the contractility of failing cardiomyocytes. The improvement of contractility in failing cells overexpressing FKBP12.6 correlated with retention of exogenous FKBP12.6 on RyR2 as assessed by co-immunoprecipitation. In failing cells overexpressing FKBP12, the trend towards improved contractility did not reach statistical significance. However, in the sham control group, overexpression of both FKBP isoforms significantly increased contractility, similar to the observations reported for the overexpression of FKBP12 and FKBP12.6 in non-failing cardiomyocytes. 
These results demonstrate, on one hand, that in rabbit heart, FKBP12.6 is not the only isoform which is capable of interaction with RyR2 and modulation of its function. Secondly, that FKBP12.6 overexpression in rabbit failing cardiomyocytes restores contractile function most probably due to retention of FKBP12.6 on RyR2. 


\section{INTRODUCTION}

\subsection{Key pathways involved in calcium transport in cardiomyocytes}

The process ensuring contraction and relaxation of the heart is called excitationcontraction coupling (E-C coupling) and involves a series of events from electrical excitation of the myocyte to contraction of the heart (Bers, 2002). Calcium is the central regulator of cardiac E-C coupling and plays a crucial role in all stages of this process, beginning from the contribution to action potential (the initiating event in cardiac E-C coupling) and ending with the activation of the myofilaments (which are the end effectors of E-C coupling). Calcium homeostasis during $\mathrm{E}-\mathrm{C}$ coupling is altered in the failing heart; therefore, it is important to have a clear comprehension of how cellular calcium levels are regulated during the normal contraction-relaxation cycle.

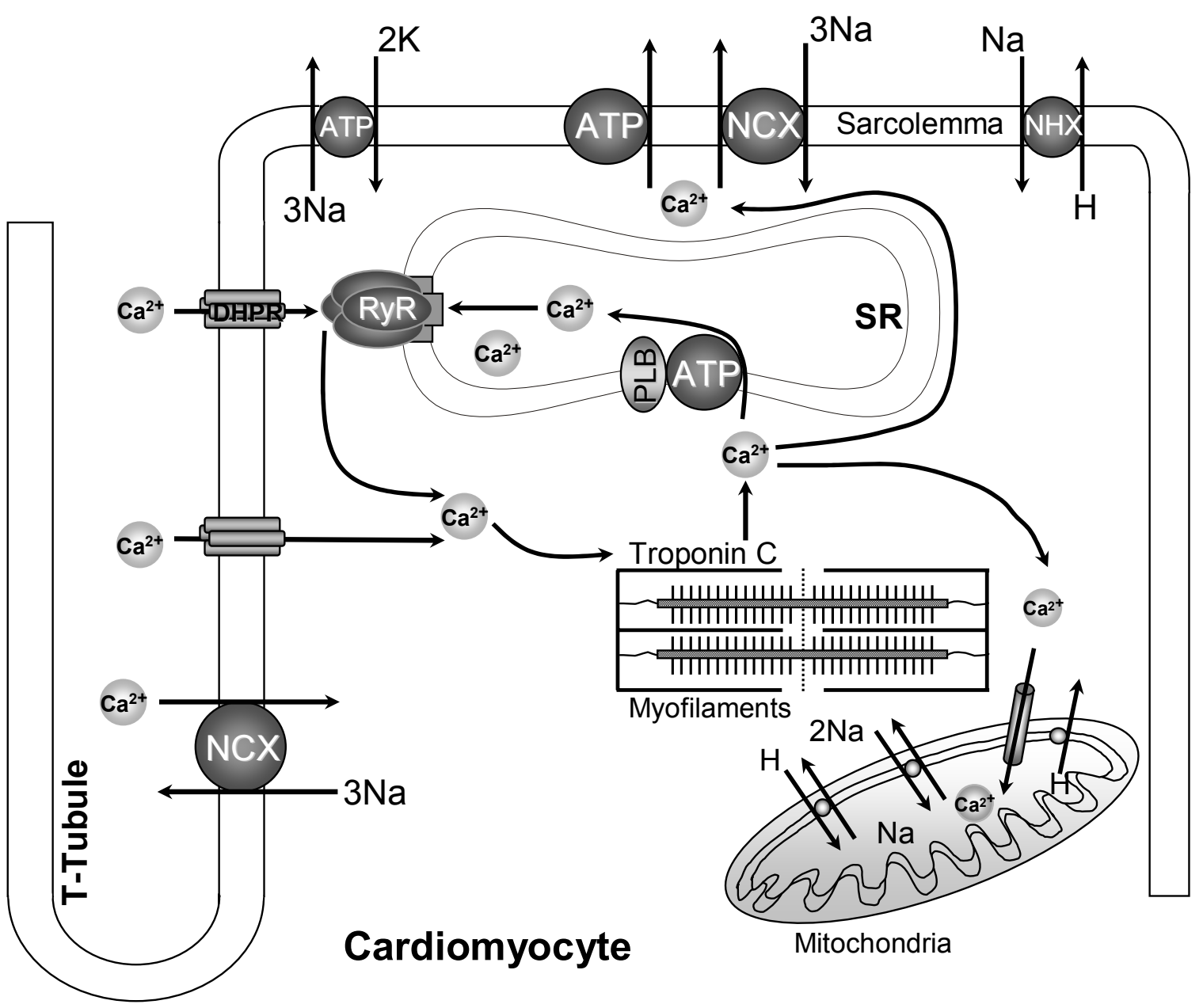

Figure 1. Schematic representation of key pathways involved in $\mathrm{Ca}^{2+}$ transport in the cardiomyocyte. During the cardiac action potential, $\mathrm{Ca}^{2+}$ enters the cardiomyocyte via $\mathrm{Ca}^{2+}$ channels (DHPR) and triggers $\mathrm{Ca}^{2+}$ release from the sarcoplasmic reticulum (SR) via the SR $\mathrm{Ca}^{2+}$ release channel (RyR). At the same time, a much smaller amount of $\mathrm{Ca}^{2+}$ enters the cell via $\mathrm{Na}^{+}-\mathrm{Ca}^{2+}$ exchanger (NCX). $\mathrm{Ca}^{2+}$ is removed from the thin-filament protein troponin $\mathrm{C}$ and cytosol by the SR $\mathrm{Ca}^{2+}$-ATPase pump (modulated by phospholamban, PLB), sarcolemmal $\mathrm{Ca}^{2+}$-ATPase pump, $\mathrm{Na}^{+}-\mathrm{Ca}^{2+}$ exchanger and mitochondrial $\mathrm{Ca}^{2+}$ uniporter. 
Figure 1 shows the key pathways involved in myocyte $\mathrm{Ca}^{2+}$ transport. During the cardiac action potential, voltage-operated $\mathrm{Ca}^{2+}$ channels known as dihydropyridine receptors (DHPR) are opened and $\mathrm{Ca}^{2+}$ enters the cell via $\mathrm{Ca}^{2+}$ current. This event, in turn, triggers the release of a larger amount of $\mathrm{Ca}^{2+}$ from the sarcoplasmic reticulum $(\mathrm{SR})$, the intracellular $\mathrm{Ca}^{2+}$ store, via $\mathrm{SR} \mathrm{Ca}^{2+}$-release channel $(\mathrm{SRCRC})$. As a combined result of $\mathrm{Ca}^{2+}$ influx and release, the free intracellular $\mathrm{Ca}^{2+}$ concentration raises, causing $\mathrm{Ca}^{2+}$ binding to myofilament troponin $\mathrm{C}$, which then switches on the contractile machinery. For relaxation to occur, intracellular $\mathrm{Ca}^{2+}$ must decline, requiring $\mathrm{Ca}^{2+}$ transport out of the cytosol. This occurs via four pathways (Bassani et al., 1992) involving SR $\mathrm{Ca}^{2+}$-ATPase, sarcolemmal $\mathrm{Na}^{+} / \mathrm{Ca}^{2+}$ exchanger, sarcolemmal $\mathrm{Ca}^{2+}-$ ATPase and mitochondrial $\mathrm{Ca}^{2+}$ uniporter.

Well-coordinated functioning and interaction of these systems are required for the maintenance of calcium homeostasis - the dynamic and, at the same time, delicate balance, which allows the heart to function effectively.

\section{$1.2 \mathrm{Ca}^{2+}$-release through $\mathrm{SR}$ calcium release channel (ryanodine receptor) as the} key event of cardiac E-C coupling

The crucial event in cardiac E-C coupling is $\mathrm{Ca}^{2+}$ release from the SR via SRCRC also known as type 2 ryanodine receptor (RyR2), since the plant alkaloid ryanodine, originally used to identify the channel protein, is a selective and specific ligand for the channel (Meissner, 1986). The process of $\mathrm{Ca}^{2+}$ release from the SR is called $\mathrm{Ca}^{2+}$ induced $\mathrm{Ca}^{2+}$ release $(\mathrm{CICR})$, since it is triggered by $\mathrm{Ca}^{2+}$, which serves as a physiological ligand for the ligand-activated RyR2 channel. $\mathrm{Ca}^{2+}$ activation of the SRCRC begins at low cytosolic $\mathrm{Ca}^{2+}$ (submicromolar), reaches a maximum, which is characterized by a very high open probability $\left(P_{0}\right)$ of the channel, near $100 \mu \mathrm{M} \mathrm{Ca}^{2+}$, and decreases at very high $(5-10 \mathrm{mM}) \mathrm{Ca}^{2+}($ Bers, 2001).

\subsubsection{Molecular structure of ryanodine receptors}

Besides the cardiac-specific RyR2 isoform, two other isoforms of RyR exist - RyR1 and RyR3. RyR1 is expressed predominantly in skeletal muscle, where it was originally described (Sorrentino and Volpe, 1993), whereas RyR3 is expressed mainly in the brain, where it was first revealed (Sorrentino and Volpe, 1993), and, therefore, they are also known as skeletal and brain RyR isoforms, respectively. These three RyR isoforms are products of 3 separate genes sharing $\sim 66 \%$ homology in amino acid sequence; they are the largest ion channel structures identified to date. RyR2 is a homotetramer with 
$\sim 565$ kDa molecular weight per protomer (Nakai et al., 1990; Otsu et al., 1990) and $\sim 2.3$ million daltons for the whole molecule.

Electron microscopy of purified and reconstituted RyR1 (Inui et al., 1987b; Lai et al., 1988) and RyR2 (Inui et al., 1987a) revealed the four-leaf clover structure, which previously had been described for the junctional "feet" - SR structural elements that span the gap between the $S R$ and transverse invaginations (T-tubules) of the plasmalemma at their junctions. On the basis of this quatrefoil appearance and comparable size, RyR was identified as the "feet" structures. This location of RyRs is undoubtedly important in the process of triggering $\mathrm{SR} \mathrm{Ca}{ }^{2+}$ release during $\mathrm{E}-\mathrm{C}$ coupling, since SRCRCs are located closely to the voltage sensors, DHPRs, and such proximity permits in the heart tight functional coupling between plasmalemmal DHPR and RyRs in the SR, although the mechanistic basis of this interaction is still unknown (Mackrill, 1999).

Three-dimensional reconstructions of the RyR based on electron microscopic images revealed the structural properties of the channel (Wagenknecht et al., 1989; Samso and Wagenknecht, 1998). Binding sites of some proteins interacting with RyR were localized on the three-dimensional reconstruction of the RyR (Wagenknecht et al., 1994; Wagenknecht et al., 1996; Wagenknecht et al., 1997; Zhang et al., 2003). Based on the analysis of the predicted secondary structure, the topology of RyR was proposed. Approximately $20 \%$ of the channel structure form transmembrane domains, spanning the SR membrane. The number of transmembrane domains is disputed and thought to range from 4 to 12 (Takeshima et al., 1989; Otsu et al., 1990), however existence of M1-M4 is consistent with most data (Bers, 2001). Site-directed mutagenesis studies in a RyR motif (located in M3-M4 region and highly conserved for all RyR isoforms) has identified it as a pore-forming segment of RyRs (Zhao et al., 1999). The remaining $\sim 80 \%$ of the RyR structure constitute an N-terminal cytoplasmic domain, which, as was demonstrated by Marx and colleagues (Marx et al., 2000), represents a major site of interaction with accessory proteins of the RyR. These proteins modulate and regulate channel function and thereby play an important role in maintenance of calcium homeostasis.

\subsubsection{The cardiac RyR channel is a regulable macromolecular signalling complex}

On the basis of co-purification and co-immunoprecipitation experiments, Marx et al. have shown that RyR2 is a macromolecular signalling complex, within which regulatory proteins (including kinases and phosphatases with their adaptor/anchoring proteins) are 
bound to specific binding sites on the cytoplasmic portion of the channel (Marx et al., 2000). In addition to RyR-associated regulatory proteins reported by Marx and colleagues, there are a number of other proteins which are known to interact with RyR2 and play a role in regulation of its function (Fig. 2).

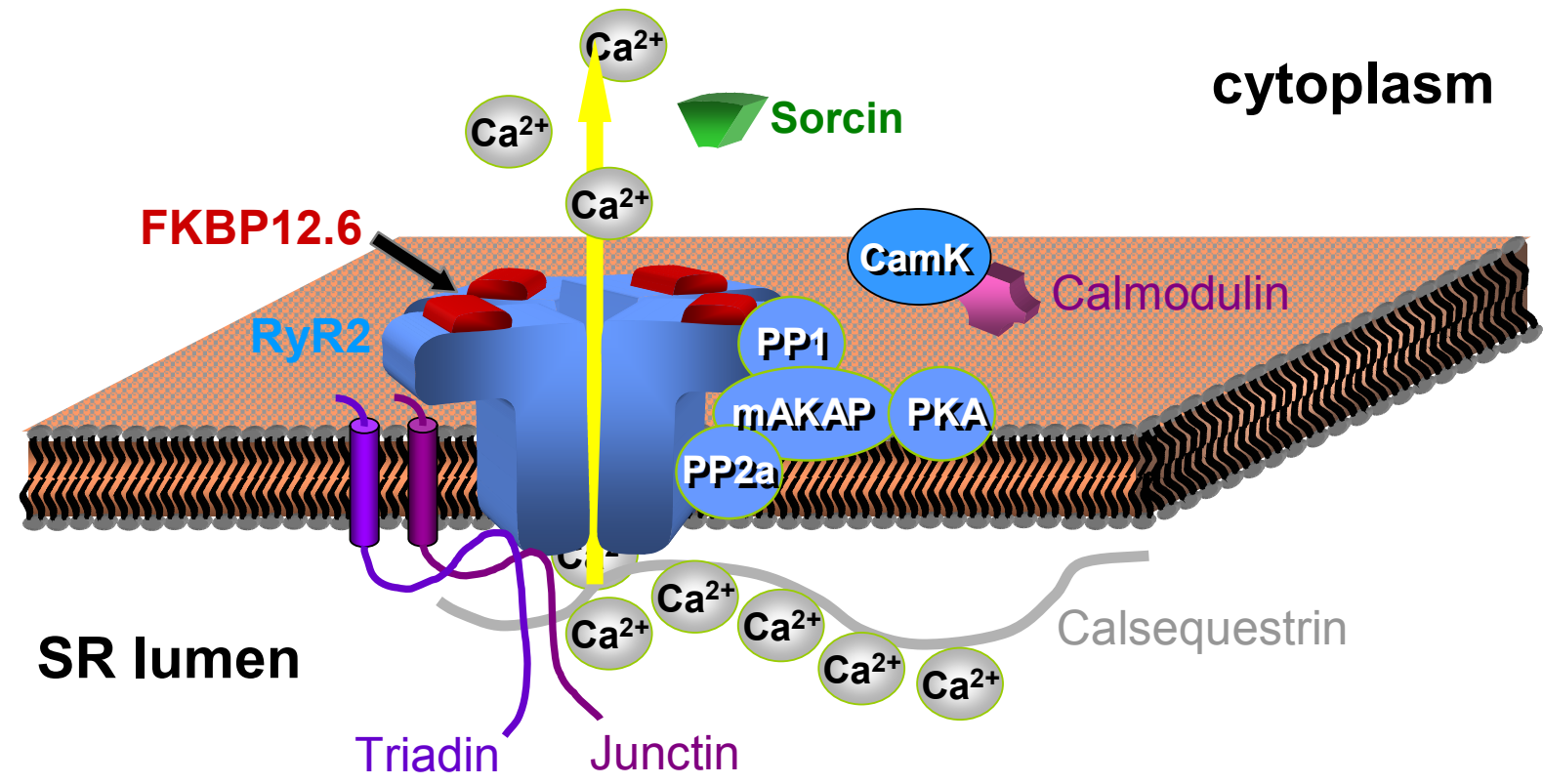

Figure 2. Model of SR $\mathrm{Ca}^{2+}$-release channel (RyR2) associated with its accessory proteins.

In the classification offered by Mackrill (Mackrill, 1999), accessory proteins of the RyR2 are categorized according to their subcellular localization into (i) SR intralumenal modulatory proteins, (ii) SR integral membrane proteins and (iii) cytosolic modulatory proteins. Some accessory proteins are worth to be briefly described here to illustrate their functions in the fine-tuning of RyR2:

- Intralumenal $\mathrm{Ca}^{2+}$ storage protein calsequestrin (CS), which is a determinant of $\mathrm{Ca}^{2+}$ loading of the SR and hence of the rate of $\mathrm{Ca}^{2+}$ release from there.

- SR integral membrane proteins triadin and junctin, both of which interact with CS, RyR2 and with each other (Zhang et al., 1997), forming a quaternary complex, which is involved in the accumulation and release of $\mathrm{Ca}^{2+}$ from the $\mathrm{SR}$.

- Multiple cytosolic modulatory proteins, such as cAMP-dependent protein kinase (PKA), $\mathrm{Ca}^{2+}$-dependent protein kinase (PKC) and calmodulin-dependent protein kinase II (CaMKII). Marx et al. have shown that PKA as well as protein phosphatase 2A (PP2A) and protein phosphatase 1 (PP1) are co-purified and coimmunoprecipitated with RyR2, and on the basis of this observation suggested that phosphorylation of the channel is locally controlled (Marx et al., 2000). The 
role of this control in the modulation of $\mathrm{SR} \mathrm{Ca}^{2+}$ release will be further discussed below. To the same group of cytosolic modulatory proteins belong the FK506binding proteins (FKBPs). FKBPs and their role in the regulation of RyR2 will be discussed in detail in the next chapters. Sorcin and calmodulin are two $\mathrm{Ca}^{2+}$ binding proteins directly associated with RyR2. Sorcin is known to inhibit RyR2 activity (Lokuta et al., 1997), so does calmodulin. (Bers, 2001). It is still unclear whether calmodulin exerts direct functional effects on cardiac RyR or whether it modifies channel activity via CaMKII pathway (Bers, 2001).

Thus, $\mathrm{Ca}^{2+}$ channels are integral regulable systems subjected to many regulatory influences by means of protein-protein interactions. The purpose of such regulation is to provide adaptive variations in the functioning of SRCRCs.

\subsection{Regulation of RyR channel by FK506-binding proteins (FKBPs)}

\subsubsection{Biology of FKBPs}

Among the proteins regulating RyRs activity are proteins of the immunophillin family FKBP12 and its orthologous isoform FKBP12.6. The immunophillin family includes proteins of different molecular weights ranging from 12 to $56 \mathrm{kDa}$ (Abraham and Wiederrecht, 1996), upon which their numbering is based. All of them are soluble receptors for immunosuppressant drugs FK506 (hence their name FK506-binding proteins - in short FKBPs) and rapamycin. They possess cis-trans peptidyl-prolyl isomerase activity (PPlase activity), which is essential for protein folding during protein synthesis. Of all FKBPs only FKBP12 and FKBP12.6 have relevance to immunosuppressive effect of FK506 (Bram et al., 1993; Sewell et al., 1994). FK506 (tacrolimus) is an immunosuppressive macrolide antibiotic used for prevention of organ graft rejection (Jain et al., 2000). FK506-FKBP binary complex binds to and inhibits calcineurin ( $\mathrm{CaN}$ ), a $\mathrm{Ca}^{2+}$-calmodulin-dependent serine-threonine phosphatase (Liu et al., 1991). Inhibition of $\mathrm{CaN}$, in turn, blocks nuclear translocation of the nuclear factor of activated T-lymphocytes (NF-AT), controlling the expression of the interleukin-2 gene, and subsequent T-cell activation (Flanagan et al., 1991). Although FK506 inhibits PPlase activity, this peptidyl-prolyl isomerase inhibition is unrelated to immunosuppression (Sewell et al., 1994). FKBP12 is the predominant and ubiquitously expressed isoform; its sequence is highly conserved throughout the phylogeny of eukaryotes (Siekierka et al., 1990; Schreiber, 1991). FKBP12.6 was initially described by Timerman and colleagues in 1994 (Timerman et al., 1994) and human FKBP12.6 
was cloned and characterized by different groups (Sewell et al., 1994; Arakawa et al., 1994; Lam et al., 1995). These two FKBP isoforms are coded by distinct genes. FKBP12.6 is closely related to FKBP12, has the same number of amino acids and differs from the latter in only 18 out of 108 amino acid residues (Sewell et al., 1994). FKBP12.6 is expressed in a range of tissues (Arakawa et al., 1994), but is less abundant than FKBP12 (Sewell et al., 1994; Lam et al., 1995). In pharmacological aspect, both FKBP isoforms are similar: they have equal affinities for FK506 and are equipotent mediators of CaN inhibition by FK506 (Lam et al., 1995).

Besides binding FK506, physiological functions of FKBPs have been defined. One of them is the regulation of RyRs (see 1.3.2). In addition, other cellular functions were described for FKBP12, such as modulation of inositol 1,4,5-trisphosphate receptor ( $\operatorname{ns} P_{3} R$ ), which is closely related to RyR, both belong to the same superfamily of intracellular $\mathrm{Ca}^{2+}$ release channels (Cameron et al., 1997). Furthermore, FKBP12 is known to inhibit type I receptor of transforming growth factor- $\beta$ (TGF- $\beta$ ) superfamily (Wang et al., 1996). There is evidence that FKBP12.6 is involved in regulation of insulin biosynthesis and its secretion from pancreatic islets by modulating intracellular $\mathrm{Ca}^{2+}$ levels via cADP-ribose and RyR (Noguchi et al., 1997).

\subsubsection{RyRs-FKBPs interaction and its putative physiological functions}

\section{Current concept: RyR1-FKBP12/RyR2-FKBP12.6 association}

The first indication of RyR interaction with FKBP12 was documented in the experiment of Collins, who, by analyzing the sequence of purified rabbit skeletal muscle RyR, found a 15-residue peptide (named KC7), which was identified as the N-terminus of FKBP12 (Collins, 1991). Next, Jayaraman et al., utilizing co-purification and coimmunopreciptation techniques, found that FKBP12 and RyR are tightly associated in rabbit skeletal muscle SR (Jayaraman et al., 1992). Timerman et al. reported tight association of canine cardiac RyR2 with a novel FK506-binding protein (Timerman et al., 1994). Blotting the fractions containing canine heart SR and purified canine RyR2 with an antibody raised against the N-terminus of FKBP12 and not reacting with other FKBP isoforms revealed the presence in these fractions of an immunoreactive single band readily distinguished from human recombinant FKBP12 due to a slight difference in their electrophoretic mobilities, whereas cardiac cytosolic fraction contained only the FKBP12 isoform (Timerman et al., 1994). Shortly after this report, Sewell and coworkers, while screening brain and kidney tissues for the presence and abundance of 
known FKBP and calcineurin isoforms, identified a novel 12.6-kDa FKBP, named FKBP12.6 (Sewell et al., 1994). FKBP12.6, purified and characterized by Sewell, was shown to be identical to the protein reported by Timerman (Lam et al., 1995).

In canine heart, interaction between RyR2 and FKBP12.6 appears to be highly specific. Using ${ }^{35}$ S-labeled recombinants of FKBP12 and FKBP12.6, Timerman et al. performed exchange studies (assays for exchange of bound FKBPs for soluble ${ }^{35}$ S-labeled FKBP recombinants), demonstrating that only labeled FKBP12.6 exchanged with endogenous FKBP12.6 bound to canine cardiac microsomes. By contrast, both FKBP isoforms exchanged with endogenously bound FKBP12 of skeletal muscle SR of the same species (Timerman et al., 1996). In addition, to confirm the specificity of FKBP12.6-RyR2 interaction, the same group used the approach of RyR2 affinity purification, based on the tight association between RyR2 and FKBP12.6, and showed that recombinant GST-FKBP12.6 is able to pull down RyR2 from canine SR, in contrast to GST-FKBP12 which fails to do so (Timerman et al., 1996). On the basis of these experiments, it was concluded that binding of FKBP12.6 by cardiac RyR is selective. To assess the amino acid residues of FKBP12.6 that confer its selective association, Xin and colleagues applied site-directed mutagenesis to the residues of human FKBP12.6 that differ from FKBP12 and used canine cardiac SR prelabeled with [ ${ }^{35}$ S]FKBP12.6 as assay system for binding/exchange with the mutants (Xin et al., 1999). These studies revealed that three amino acid residues $\left(\mathrm{Gln}^{31}, \mathrm{Asn}^{32}\right.$ and $\left.\mathrm{Phe}^{59}\right)$ of FKBP12.6 determine its selective binding to RyR2. Binding specificity may also arise from variations in sequence and structure of different RyR isoforms, therefore, a number of studies have focused on the structural basis of FKBP-RyR interaction (Cameron et al., 1997; Marx et al., 2000; Gaburjakova et al., 2001; Bultynck et al., 2001a; Bultynck et al., 2001b; Fulton et al., 2003; Masumiya et al., 2003).

Thus, upon co-purification, co-immunoprecipitation and exchange/binding experiments is based the current concept that FKBP12.6 is bound to cardiac RyR, whereas FKBP12 is associated with skeletal muscle RyR isoform solely and, consequently, plays a role in RyR regulation only in skeletal muscle.

Putative physiological functions of FKBPs with respect to interaction with RyRs

Each FKBP isoform interacts with its corresponding RyR isoform in a stoichiometry of 4 to 1, i.e. four FKBP molecules per RyR tetramer (Timerman et al., 1993; Timerman et al., 1995; Timerman et al., 1996). FK506 and rapamycin cause dissociation of FKBPs from RyRs and modify RyR1 and RyR2 gating in bilayer studies. 
Brillantes et al. showed that recombinant RyR1 expressed in insect cells (Sf9), which do not express detectable amounts of either RyR1 or FKBP12, exhibited subconductance states - or partial openings - of different levels. When human recombinant FKBP12 was co-expressed with RyR in Sf9 or added to RyR incorporated into bilayers, stable channels with openings to full conductance state were formed; addition of FK506 or rapamycin to either native RyR or RyR co-expressed with FKBP12 induced reappearance of subconductance state (Brillantes et al., 1994). This observation indicated, for the first time, that FKBP12 may stabilize RyR1. Kaftan et al. reported analogous results with regard to RyR2: when rapamycin was added to cardiac SR channels comprising RyR2 and FKBP12.6, profound changes were induced in channel gating manifested by activation of the channel (increased open probability) and appearance of subconductance states (Kaftan et al., 1996).

Using a dissociation/reconstitution approach, Timerman et al. showed that skeletal muscle RyR from SR treated with FK590 (a structural analogue of FK506) had a greater sensitivity to activation by $\mathrm{Ca}^{2+}$ than channels from untreated SR (Timerman et al., 1995), which provoked the appearance of subconductance states and increased open probability (not full closure), as reported Brillantes and Kaftan. Altered channel properties were restored by rebinding FKBP12 to RyR from stripped skeletal SR (Timerman et al., 1995). In the same study, Timerman and colleagues showed that PPlase-deficient FKBP-mutants did not alter the $\mathrm{Ca}^{2+}$ flux of SR vesicles when they substituted for wild-type FKBP12 on RyR. When these mutants were added to drugstripped SR, they restored properties of the channel in a similar manner as wild-type FKBP12, providing evidence that modulation of RyR channels by FKBPs is independent of PPlase activity.

Using the same dissociation/reconstitution approach, Timerman et al. demonstrated that neither removal nor addition of FKBP12.6 to RyR2 of stripped canine cardiac SR had any effect on channel activity (Timerman et al., 1996) and concluded that the mechanism of RyR modulation by FKBP might be different in heart and in skeletal muscle. Applying the same dissociation/reconstitution approach to lipid bilayers, Barg et al. found no effect of FK506 on RyR2 (Barg et al., 1997). In contrast, FK506 treatment increased the duration of spontaneous or depolarization-evoked $\mathrm{Ca}^{2+}$ transients in intact cardiomyocytes and induced long-lasting subconductance states in cardiac RyRs incorporated in planar lipid bilayers (Xiao et al., 1997). The discrepancy between the results obtained by different groups, utilizing similar in vitro techniques, 
may originate from the composite character of $\mathrm{SR} \mathrm{Ca}^{2+}$ release - a process that is difficult to reconstruct in vitro.

To investigate the role of FKBP12.6 in cardiac E-C coupling, Prestle et al. used adenovirus-mediated gene transfer to overexpress FKBP12.6 in isolated rabbit ventricular myocytes, followed by contractility measurements and SR $\mathrm{Ca}^{2+}$-uptake measurements in cardiomyocytes overexpressing FKBP12.6. These studies showed that overexpression of FKBP12.6 in rabbit cardiomyocytes had three significant effects, such as, reduction of RyR2 mediated $\mathrm{Ca}^{2+}$ efflux from SR, higher SR $\mathrm{Ca}^{2+}$ load and, as a result, increased amplitude of contractility in single myocytes (Prestle et al., 2001).

Thus, the working hypothesis regarding the role of FKBPs in RyR modulation is that FKBP physically stabilizes the coordinated gating of the 4 RyR subunits within the homotetramer so that openings go from the fully closed to the fully open state (Bers, 2001). Moreover, as demonstrated by Marx et al., FKBP may also be involved in a process known as coupled gating - simultaneous opening and closure of two or more physically connected RyR channels (Marx et al., 1998). Both cardiac and skeletal RyRs are arranged on the SR membrane in closely packed arrays, such that their large cytoplasmic domains are physically in contact to one another (Protasi et al., 1998). Due to this arrangement, individual channels are capable of coordinated opening-closure (coupled gating), providing a mechanism for regulating the $\mathrm{Ca}^{2+}$ signal required for E-C-coupling (Marx et al., 1998; Marx et al., 2001a). Marx et al. showed that addition of FKBP12/12.6 induced simultaneous gating of 2 or more entire RyR1/RyR2 channels, and this effect could be reversed by removal of FKBP with rapamycin, but nevertheless physical association between RyRs was preserved (Marx et al., 1998; Marx et al., 2001a). From this was concluded that FKBP is involved in the functional coupling between RyRs but does not influence physical coupling of RyR oligomers. Indeed, Yin and Lai showed that lattice formation is an intrinsic property of RyR channels and that cytoskeletal elements, cytosolic proteins or membrane insertion are not necessary for this phenomenon (Yin and Lai, 2000).

Cryoelectron microscopy revealed binding of FKBP12 to the cytoplasmic assembly of RyR1 channels at sites that are $12 \mathrm{~nm}$ from the putative entrance to the transmembrane pore. FKBP12 binds along the edge of the square-shaped cytoplasmic assembly near the face that interacts in vivo with the transverse tubule of the sarcolemma (Wagenknecht et al., 1996; Wagenknecht et al., 1997). FKBP12.6 binding sites have also been mapped to a similar region on the three-dimensional structure of RyR2 
(Zhang et al., 2003). Such location of FKBPs seems to be relevant to observations regarding the functional role of FK506-binding proteins in regulation of RyR channels.

\section{FKBP12-RyR2 interaction?}

Most aforesaid in vitro studies support the hypothesis that RyR2 is associated with FKBP12.6 rather than FKBP12 and, hence, FKBP12.6 modulates the activity of RyR2 in the heart, whereas FKBP12 is not important for the regulation of cardiac E-C coupling. However, considerably higher expression levels of FKBP12 than FKBP12.6 in the heart of several species (Lam et al., 1995; Shou et al., 1998; Prestle et al., 2001) raise doubts as to an exclusive role of FKBP12.6 isoform in the regulation of RyR2. Indeed, some studies challenge the current concept, raising questions as to the isoform specificity of FKBP interaction with RyR2.

Data reported by Shou et al. are perhaps the most perplexing and call for a revision of the current point of view regarding the RyR2-FKBPs interaction/regulation. This group showed that FKBP12-knockout mice had gross developmental abnormalities in the heart, such as severe dilated cardiomyopathy and ventricular septal defects, but at the same time, there were no gross, histological or electron microscopic abnormalities in their skeletal muscle. However, both RyR1 and RyR2 from these mice were reported to have altered single channel behavior, such as increased probability of channel openings and subconductance states of the channels (Shou et al., 1998). These physiological studies using FKBP12-knockout model demonstrate that FKBP12 modulates both skeletal and cardiac muscle RyR and that FKBP12.6 can not functionally substitute for FKBP12. The absence of skeletal muscle dysfunction reported in this study was attributed to different E-C coupling mechanisms in skeletal vs. cardiac muscles.

Since FKBP12 is phylogenically well conserved, the implication of FKBP12 in regulation of cardiac RyR2 and/or E-C coupling might be extrapolated to other vertebrates. As already mentioned, the concept that FKBP12.6, but not FKBP12, is tightly associated with cardiac SR and RyR2 is based on co-purification, co-immunoprecipitation and exchange/binding experiments using canine cardiac material. Indeed, until recently, canine cardiac RyR served as prototype for studying the association of RyR2 with FKBP (Timerman et al., 1994; Lam et al., 1995; Timerman et al., 1996; Xin et al., 1999), but it was not known which of the FKBP isoforms was associated with cardiac SR and RyR in other species.

The first systematic studies of FKBP association with RyR2 from heart microsomes enriched in SR from different mammals (human, rabbit, rat, mouse and dog) and other 
vertebrate classes (chicken, frog, and fish) were carried out by Jeyakumar et al. (Jeyakumar et al., 2001). In their study, cardiac microsomes enriched in SR were isolated from diverse vertebrates and characterized with respect to their RyR2 content and association with FKBP isoforms. The results revealed that SR of seven out of eight tested species contained both FKBP12.6 and FKBP12, dog being the exception where cardiac SR bound only FKBP12.6. From [ ${ }^{35}$ S]FKBP12 and $\left[{ }^{35}\right.$ S]FKBP12.6 exchange isotherms, a stoichiometry of binding sites for both FKBP12 and FKBP12.6 to ryanodine receptor was calculated to be approximately 4 per RyR tetramer for different mammals, except dog. The affinity of FKBP12 for RyR2 from SR of mammals was on average only 7-fold weaker (higher $\mathrm{K}_{\mathrm{d}}$ ) than that of FKBP12.6, unlike to dog, where FKBP12 binding/exchange with RyR2 was negligible due to an approximately 500-fold weaker affinity compared to FKBP12.6 (Timerman et al., 1996). Thus, from these extensive studies, Jeyakumar et al. concluded that the association of FKBPs with RyR2 in diverse vertebrates is conserved in heart, albeit the affinity for FKBP12.6 is greater than for FKBP12.

Previously, Qi and colleagues reported similar results with regard to RyR1. They characterized RyR1 from skeletal muscle microsomes of each of the five classes of vertebrates, i.e. mammals (rabbit), birds (chicken), reptiles (turtle), amphibians (frog), and fish (salmon and rainbow trout), with respect to its association with FKBP12 isoform and its capability of exchange with soluble FKBP12 and FKBP12.6. Exchange isotherms of $\left[{ }^{35} \mathrm{~S}\right] \mathrm{FKBP} 12$ and $\left[{ }^{35} \mathrm{~S}\right] \mathrm{FKBP} 12.6$ with RyR1 from terminal cisternae of different animals revealed that both FKBP isoforms bound comparably to RyR1 and the stoichiometry of FKBP12 or FKBP12.6 binding sites/RyR tetramer was calculated to be approximately 4 . These four binding sites could be occupied by either isoform or a combination of FKBP isoforms (Qi et al., 1998).

In order to assess the role of FKBP12.6 in cardiac function, FKBP12.6-knockout mouse model was developed by several groups. Xin and colleagues reported that in their model, FKBP12.6-knockout mice appeared normal in most respects, but exhibited cardiac hypertrophy in males but not in females (Xin et al., 2002). Wehrens and Lehnart et al. reported that FKBP12.6-deficient mice showed no structural cardiac abnormalities, no echocardiographic abnormalities or arrhythmias at rest, but cardiac ventricular arrhythmias followed by sudden cardiac death was provoked by exercising FKBP12.6deficient mice (Wehrens et al., 2003). In both FKBP12.6-knockout models, the cardiac phenotype was undoubtedly less severe compared to FKBP12-deficient mice, what once more underscores the importance of FKBP12 for heart development and function. 
Thus, in spite of a great number of evidences accumulated, the precise mode of interaction and modulation of cardiac RyR by FKBP12.6/FKBP12 remains to be fully defined.

\subsubsection{Clinical relevance of FKBPs-RyR2 association/regulation}

Alteration of FKBP12.6-RyR2 association in heart failure and PKA-dependent hyperphosphorylation of RyR2 as a putative mechanism of this alteration

One more reason why such high emphasis is placed on FKBPs-RyR2 interaction is that FKBP effects may be clinically relevant and FK506 treatment can be associated with cardiomyopathy (Atkison et al., 1995).

Marx et al. showed that PKA phosphorylation of immunoprecipitated RyR2 (at no phosphorylation of FKBP12.6) resulted in a decrease ( 90\%) in the amount of FKBP12.6 co-immunoprecipitating with RyR2. In the same study they showed that RyRs in failing heart of dog and human were hyperphosphorylated specifically by PKA and, furthermore, less FKBP12.6 co-immunoprecipitated with RyR2 from failing hearts of both species compared to normal hearts $(65 \%$ and $50 \%$ of reduction in humans and dogs, respectively) (Marx et al., 2000). Furthermore, single channel recordings of RyR2 channels from failing human and canine hearts exhibited the same alterations in gating properties as in PKA-phosphorylated channels from normal hearts, namely increased $\mathrm{P}_{\mathrm{o}}$ at low cytosolic $\left[\mathrm{Ca}^{2+}\right]$ and appearance of subconductance states (Marx et al., 2000). This group attempted to explain PKA-mediated hyperphosphorylation of RyR2 under the assumption that during heart failure, catecholamine levels were markedly increased. This would via $\beta$-adrenergic signalling pathway generate increased cAMP levels and activate PKA. But it was shown previously that in failing heart, $\beta$-adrenergic receptors $(\beta-A R)$ are, first, downregulated and, second, uncoupled from their downstream signalling molecules, G proteins (Bristow et al., 1992). cAMP levels in failing human hearts were reported by different groups to be either unchanged (Regitz-Zagrosek et al., 1994; Kirchhefer et al., 1999) or reduced (Bohm et al., 1994), while PKA activity in these reports was unchanged. To overcome this dilemma and explain PKA hyperphosphorylation of RyR2, Marx et al. assessed the amounts of PKA and phosphatases (PP1 and PP2A) physically associated with RyR2 in failing hearts. Indeed, at unchanged levels of associated PKA, significantly less PP1 and PP2A were bound to RyR2. However, it was previously reported that cellular PP1 levels are increased in failing hearts (Neumann et al., 1997). Based on these observations, the 
authors hypothesized that (i) phosphorylation of RyR channel is locally controlled, (ii) downregulation of phosphatases targeted to RyR2 results in its hyperphosphorylation by PKA, and (iii) phosphorylation of RyR2 by cAMP-dependent protein kinase is a physiological pathway regulating FKBP12.6 binding to RyR channel (Marx et al., 2000). Marks has proposed that this pathway is involved in E-C coupling regulation aimed at specific increase of E-C coupling gain by enhancing the amount of $\mathrm{Ca}^{2+}$ released for a given trigger (Marks, 2000; Marks, 2001; Marx and Marks, 2002). But in failing heart this pathway becomes maladaptive, leading to pathological consequences like depletion of $\mathrm{SR} \mathrm{Ca}{ }^{2+}$ stores and aberrant release of $\mathrm{Ca}^{2+}$ during diastole (ibidem).

Studies of George et al. support the notion that $\beta$-AR-induced RyR2 hyperphosphorylation is associated with disruption of the FKBP12.6-RyR2 complex. Using in situ localization measurements and direct measurements of FKBP12.6-RyR2 protein-protein interaction they found that in a system overexpressing human RyR2, FKBP12.6-RyR2 interaction was dramatically disrupted by isoproterenol or forskolin, an activator of adenylate cyclase (George et al., 2003).

In another study by Yano et al., it has been shown that there is abnormal $\mathrm{Ca}^{2+}$ leak from the SR of canine failing heart similar to that observed in FK506-treated SR from normal hearts (Yano et al., 2000). This abnormal $\mathrm{Ca}^{2+}$ leak correlated with altered stoichiometry of FKBP12.6 interaction with RyR2. Using $\left[{ }^{3} \mathrm{H}\right]$ dihydro-FK506 and $\left[{ }^{3} \mathrm{H}\right] \mathrm{Ryanodine}$ binding assays they estimated that the molar ratio of FKBP12.6-RyR2 in SR from normal heart was approximately 4 (4 FKBP12.6 for RyR2 tetramer), whereas it was only 1.6 in failing SR. Parallel assessment of FKBP12.6 expression levels in SR by immunoblotting, revealed a significant decrease of FKBP12.6 associated with cardiac SR. Subjecting cardiac SR from failing hearts to fluorescence assay, Yano et al. concluded that a conformational change in RyR2 occurred as a consequence of FKBP12.6 dissociation from the RyR channel.

This significantly decreased stoichiometry of FKBP12.6-RyR interaction and consequent defective regulation of RyR2 leading to abnormal $\mathrm{Ca}^{2+}$ leak from the SR (Fig. 3) were suggested to contribute to the pathogenesis of heart failure. 


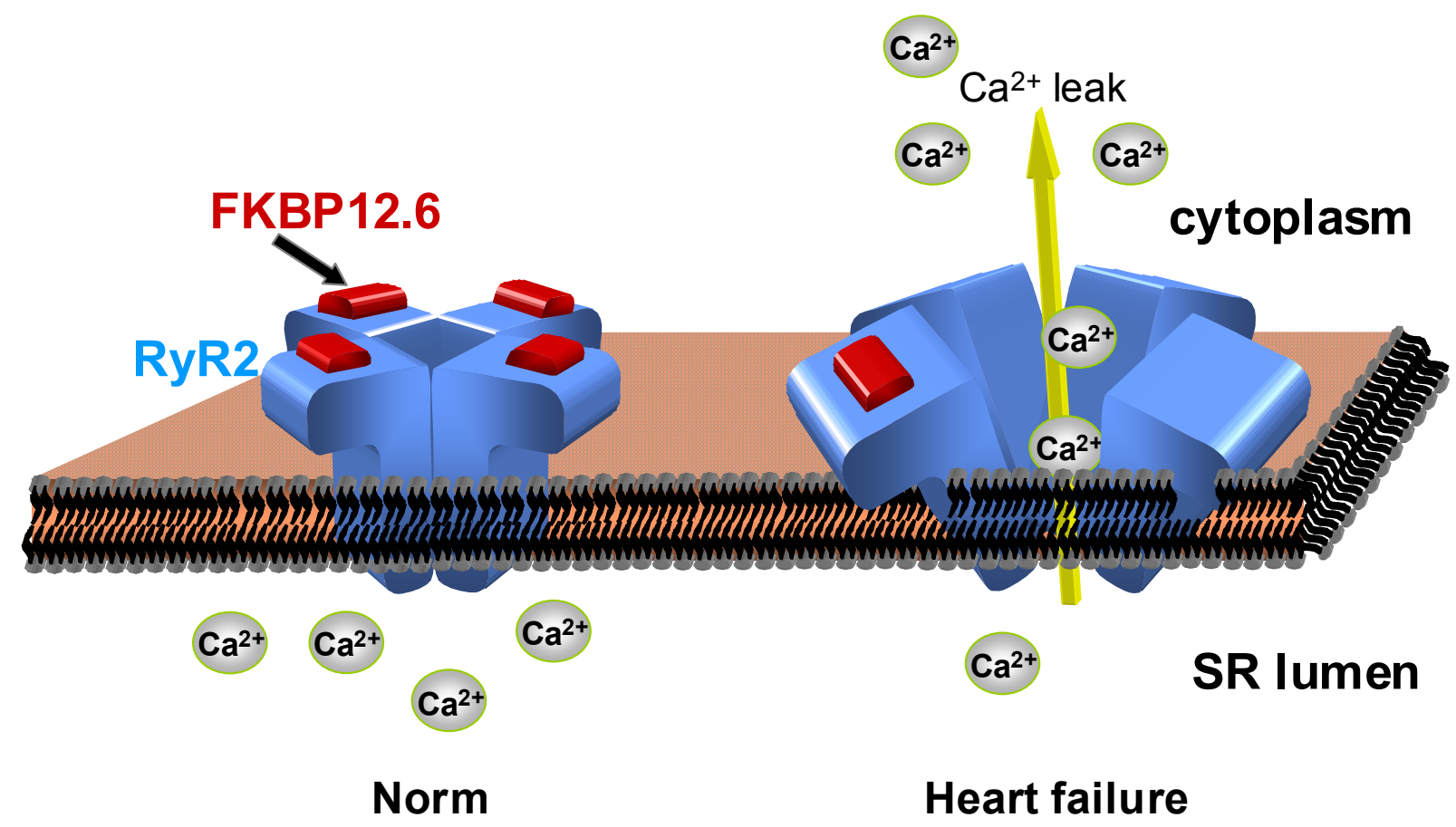

Figure 3. Altered interaction of FKBP12.6 with RyR2 in heart failure. In normal heart, immunophillin protein FKBP12.6 is tightly associated with RyR2 in a stoichiometry of $4: 1$ and physically stabilizes 4 RyR subunits in one homotetramer so that during diastole the RyR channel is fully closed. In heart failure, a partial loss of RyR-bound FKBP12.6 and consequent conformational change in RyR2 cause abnormal $\mathrm{Ca}^{2+}$ leak from the SR through RyR channel. This increased $\mathrm{Ca}^{2+}$ leak is thought to be relevant to the pathophysiology and progression of heart failure.

PKA in regulation of FKBP12.6-RyR2 interaction: alternative point of view In the hypothesis proposed by Marks and collegues, hyperphosphorylation of RyR2 by PKA in failing heart is a causative factor of FKBP12.6 dissociation from RyR2. However, the issue of whether PKA phosphorylation of RyR2 can dissociate FKBP12.6 from RyR2 is controversial.

The phosphorylation of RyR2 by PKA occurs at serine-2809 (Marx et al., 2000), which was originally identified as a unique phosphorylation site for CaMKII (Witcher et al., 1991). In several studies, Marx and colleagues showed that FKBP12.6 cannot bind to PKA-phosphorylated RyR2 (Marx et al., 2000; Marx et al., 2001b). However, they also reported that phosphorylation of RyR2 at serine-2809 by CaMKII did not influence FKBP12.6 association with RyR2 (Marx et al., 2000). The same group showed that a single mutation of serine-2809 to aspartate (S2809D), which mimics constitutively PKAphosphorylated RyR2, abolished FKBP12.6 binding to RyR2 (Wehrens et al., 2003). In the opinion of other authors, the idea of PKA-dependent dissociation of FKBP12.6 from RyR is apparently inconsistent with the observation that only PKA phosphorylation, but not phosphorylation by CaMKII, is able to dissociate FKBP12.6 from RyR, despite 
the fact that both PKA and CaMKII are able to fully phosphorylate serine-2809 (Rodriguez et al., 2003). Due to such inconsistence, Jiang et al. were the first to raise doubts as to whether phosphorylation at serine-2809 is really responsible for FKBP12.6 dissociation from RyR2. In their experiments, PKA phosphorylation of RyR2 did not dissociate FKBP12.6 from canine SR microsomes (Jiang et al., 2002). Furthermore, they also failed to reproduce another key observation underlying the scheme proposed by Marks et al. In the study of Jiang and colleagues, the phosphorylation level of RyR2 from canine failing hearts was unchanged compared to normal hearts, and the basal activity of RyR channels from failing hearts was not different from that of RyR2 from normal hearts (Jiang et al., 2002).

$\mathrm{Li}$ et al. showed that PKA-dependent RyR2 phosphorylation had no effect on $\mathrm{Ca}^{2+}$ sparks in cardiomyocytes from phospholamban (PLB)-knockout mice as well as from mice expressing only double-mutant PLB lacking in PKA phosphorylation sites. In wild type myocytes, on the other hand, cAMP dramatically increased $\mathrm{Ca}^{2+}$ spark frequency and amplitude. This group concluded that PKA-dependent effects on SR $\mathrm{Ca}^{2+}$ release are attributable to PLB phosphorylation and consequent enhancement of SR $\mathrm{Ca}^{2+}$ load (Li et al., 2002).

Furthermore, studies of Terentyev et al. provide evidence that dephosphorylation rather than phosphorylation enhances channel activity of RyR2 (Terentyev et al., 2003). Recently, Xiao et al. assessed the effect of PKA phosphorylation on FKBP12.6-RyR2 interaction (Xiao et al., 2004). They showed that, first, FKBP12.6 was able to bind to both serine-2809-phosphorylated and nonphosphorylated RyR2, second, FKBP12.6 could bind to S2809D mutant thought to mimic constitutive phosphorylation of RyR2, and third, complete phosphorylation at serine-2809 by exogenous PKA did not dissociate FKBP12.6 from either recombinant or native RyR2.

Thus, the questions of whether PKA-dependent hyperphosphorylation of RyR2 occurs in heart failure, and what, if not the phosphorylation of RyR2 by PKA, is the mechanism underlying the physiological regulation of FKBP12.6-RyR2 interaction remain unresolved.

Stabilization of cardiac ryanodine receptor via retrieval of its association with FKBP12.6 as a novel therapeutical approach to treatment of heart failure In spite of the controversy regarding the concept of RyR2 hyperphosphorylation in heart failure, there is a general agreement that disturbed SR function is the dominant factor that causes altered E-C coupling in human heart failure (Hasenfuss and Seidler, 2003). 
The major characteristic of altered SR function is a decrease of $\mathrm{SR} \mathrm{Ca}^{2+}$ content in failing heart. This reduction of $\mathrm{SR} \mathrm{Ca}^{2+}$ content is attributed to several factors, such as altered SR $\mathrm{Ca}^{2+}$ uptake due to diminished expression and activity of SR $\mathrm{Ca}^{2+}$-ATPase, unbalanced $\mathrm{Ca}^{2+}$ extrusion due to increased activity and expression of the plasmalemmal $\mathrm{Na}^{+}-\mathrm{Ca}^{2+}$ exchanger, and increased $\mathrm{Ca}^{2+}$ leak due to abnormal RyR2 function (Fig. 4).

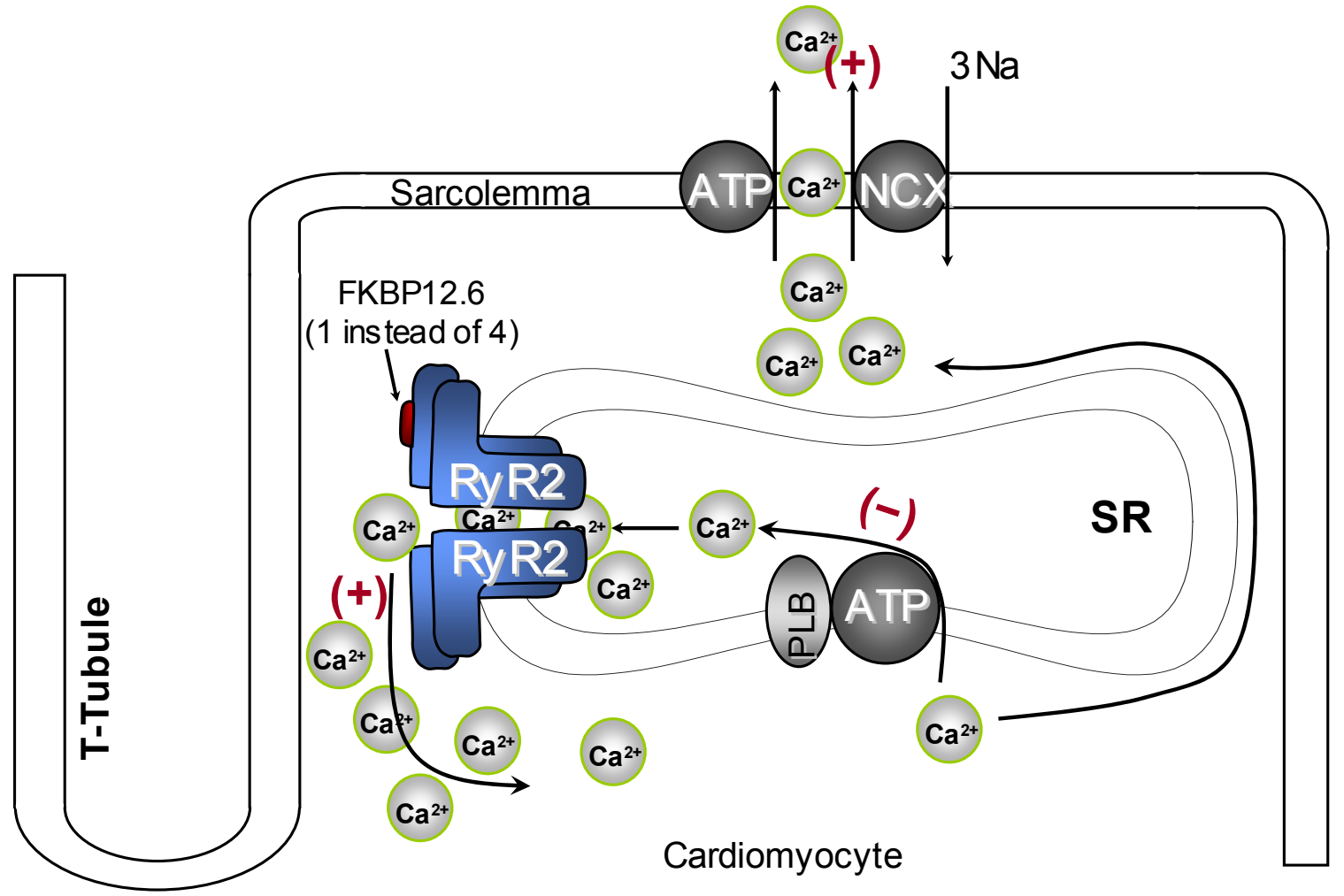

Figure 4. Major molecular alterations contributing to decrease of $\mathrm{SR} \mathrm{Ca}^{2+}$ content in failing heart. Together with such factors as abnormal density/function of $\mathrm{SR} \mathrm{Ca}^{2+}$ uptake (realized by SR $\mathrm{Ca}^{2+}-\mathrm{ATPase}$ pump) and $\mathrm{Ca}^{2+}$ extrusion (reailzed by $\mathrm{Na}^{+}-\mathrm{Ca}^{2+}$ exchanger, $\mathrm{NCX}$ ), abnormal $\mathrm{Ca}^{2+}$ leak through RyR2 due to partial loss of FKBP12.6 contributes greatly to reduction of $\mathrm{SR} \mathrm{Ca}^{2+}$ content. + and - indicate increase and decrease, respectively, in $\mathrm{Ca}^{2+}$ fluxes.

Quantitatively, the contribution of $\mathrm{Ca}^{2+}$ leak through RyRs to reduction in $\mathrm{SR} \mathrm{Ca}^{2+}$ content is not known, but its relevance to the pathophysiology and progression of heart failure is obvious. According to Hasenfuss and Seidler (Hasenfuss and Seidler, 2003), the unfavorable consequences of abnormal $\mathrm{Ca}^{2+}$ leak are the following:

1) decreased availability of $\mathrm{Ca}^{2+}$ to be released as a consequence of depletion of $\mathrm{SR} \mathrm{Ca}{ }^{2+}$ store;

2) diastolic dysfunction due to activation of contractile proteins during diastole;

3) triggering of arrhythmias;

4) altered gene expression and myocardial remodeling; 
5) increased ATP consumption.

Considering these, interventions that reduce the leak seem to be an appropriative means to rescue, at least in part, the failing phenotype. Recently, Yano et al. reported that a new agent, JTV519, reversed the stoichiometry of FKBP12.6-RyR2 interaction to the normal level and hence reduced the abnormal $\mathrm{Ca}^{2+}$ leak through the RyR, thereby preventing LV remodeling in a canine model of heart failure (Yano et al., 2003).

Considering the importance of FKBPs in the regulation of $\mathrm{SR} \mathrm{Ca}^{2+}$ handling and the relevance of this regulatory subunit of RyR macromolecular complex to the abnormal RyR2 function in heart failure, stabilization of cardiac RyR channel via retrieval of FKBP-RyR association might be a new therapeutical approach to the treatment of heart failure. 


\subsection{Aim of study}

Many studies have provided unambiguous evidence that FKBP12.6 plays an essential role in cardiac E-C coupling by modulation of the RyR2 activity. FKBP12.6 was shown to be tightly and selectively associated with cardiac RyR, however this notion was limited mainly to the canine heart. Considerably higher expression levels of FKBP12 than FKBP12.6 in the heart raise doubts as to an exclusive role of FKBP12.6 in the regulation of RyR2. Several groups raise the question of isoform specificity of FKBPsRyR2 interaction. Thus, the issue whether FKBP12 also contributes to the regulation of cardiac RyR or whether only FKBP12.6 plays a role in the regulation of cardiac E-C coupling is still open. In addition, defective regulation of RyR2 by FKBP12.6 during heart failure is another unresolved question. Considering these uncertainties, the aim of this study was:

1. to investigate whether FKBP12 contributes to the regulation of cardiac RyR/SR using adenovirus-mediated gene transfer to overexpress FKBP12 in isolated rabbit ventricular cardiomyocytes;

2. to investigate the interaction of FKBP12 with cardiac RyR and compare it with FKBP12.6-RyR2 interaction utilizing co-immunoprecipitation and GST fusion protein pulldown techniques;

3. to assess the functional interaction of FKBP12.6 with RyR2 in a rabbit model of heart failure by co-immunoprecipitation;

4. to investigate, using adenovirus-mediated gene transfer, whether FKBP12.6 and/or FKBP12 may represent new molecular target(s) to improve contractile function of failing cardiomyocytes. 


\section{MATERIALS}

\subsection{Animals}

Ventricular cardiomyocytes were isolated from female Chinchilla bastard rabbits (1.5-2 kg body weight) obtained from Charles River Laboratories (Sulzfeld). Rabbits were kept on a 12 hour day-night rhythm with free access to water and food at room temperature. The preparation of cardiomyocytes was performed during the first 3 hours of the light phase. Rabbits were anesthetized by injection of sodium-thiopental (50 $\mathrm{mg} / \mathrm{kg}$ of body weight) into an ear vein. Outlines of this study were designed and carried out in accordance with institutional guidelines regarding the care and use of animals.

\subsection{Bacterial strains, plasmid and adenovirus constructs}

\section{Bacterial strain}

E. coli BL-21 strain (genotype: $\mathrm{F}^{-}$, ompT, hsdS $\left(\mathrm{r}_{\mathrm{B}}^{-}, \mathrm{m}_{\mathrm{B}}{ }^{-}\right.$), gal) (Stratagene/Heidelberg) was used for overexpression of recombinant GST fusion proteins. BL-21 cells are deficient for proteases, which makes this strain suitable for preparation of recombinant proteins.

\section{Plasmid constructs}

FKBP12-pGEX-6P-3 or FKBP12.6-pGEX-6P-3 constructs were used for overexpression and purification of recombinant human FKBP12 and FKBP12.6 GST fusion proteins. The pGEX-6P-3 vector, on the basis of which the constructs were created, contains gene region for glutathione S-transferase tag providing means for simple one step purification and easy detection of the fusion protein.

The plasmid constructs were generously provided by Dr. W. Chen (University of Calgary, Alberta, Canada).

\section{Adenovirus constructs}

For the overexpression experiments the following adenovirus constructs were used:

- adenoviruses coding for full size human FKBP12 and FKBP12.6 (Ad-FKBP12, AdFKBP12.6);

- adenovirus coding for $\beta$-galactosidase (Ad-LacZ).

Adenoviruses carrying mentioned above genes were generated in our laboratory. 


\subsection{Oligonucleotides for polymerase chain reaction}

Oligonucleotides of HPLC grade purity for polymerase chain reaction were obtained from MWG-Biotech (München):

\begin{tabular}{|c|c|c|}
\hline PCR-primer & Gene & $\begin{array}{l}\text { DNA-fragment } \\
\text { size, bp }\end{array}$ \\
\hline Forward: 5'-CCAGGTCGCTGTGGATCCACGCCGCCCGTC-3' & \multirow{2}{*}{ Human FKBP12 } & \multirow{2}{*}{459} \\
\hline Reverse: 5'-CACATGTCTGGAGGCACCGGATCCCTCCATGGCAGA-3' & & \\
\hline Forward: 5'-CCGAGGCTGGGAAGAAGG-3' & \multirow{2}{*}{ Rabbit FKBP12 } & \multirow{2}{*}{431} \\
\hline Reverse: 5'-TCACCCCAAAACGAGAACAGA-3' & & \\
\hline Forward: 5'-AGCCCACTCCCATCCCCAACA-3' & \multirow{2}{*}{$\begin{array}{c}\text { Rabbit } \\
\text { calsequestrin }\end{array}$} & \multirow{2}{*}{353} \\
\hline Reverse: 5'-GTCAGCGTCCGTCACATTCACCA-3' & & \\
\hline Forward: 5'-GGCCGCCCAGAACATCATCC-3' & \multirow{2}{*}{ Rabbit GAPDH } & \multirow{2}{*}{436} \\
\hline Reverse: 5'-СTCTCGCTGGGCCGGTGGTTTG-3' & & \\
\hline
\end{tabular}

\subsection{Antibodies}

\section{Anti-phospho-RyR Ab (RyR2-P2809)}

For the detection of phosphorylated cardiac RyR, rabbit polyclonal antibody raised against phosphopeptide sequence of the RyR and affinity purified with this peptide was used. This antibody recognizes phosphorylated serine-2809 in RyR2 exclusively and does not react with dephosphorylated RyR2. Species reactivity: canine, human, mouse, rabbit.

The antibody was generously provided by Dr. A. Marks (Center for Molecular Cardiology, Columbia University, New York, U.S.A.).

\section{Anti-RyR Ab (RyR2-5029)}

For the detection of cardiac RyR, rabbit polyclonal anti-serum was used. Species reactivity: canine, human, mouse, rabbit, and rat.

The antibody was generously provided by Dr. A. Marks (Center for Molecular Cardiology, Columbia University, New York, U.S.A.).

\section{Anti-RyR Ab (MA3-916)}

For the detection of cardiac RyR, mouse monoclonal antibody (C3-33 clone) raised against canine cardiac ryanodine receptor was used (Affinity Bioreagents). Species reactivity: MA3-916 detects RyR2 in canine, chicken, rabbit, and rat. 
Anti-RyR Ab (MA3-925)

For immunoprecipitation of cardiac RyR, mouse monoclonal antibody (34C clone) raised against partially purified chicken pectoral muscle ryanodine receptor was used (Affinity Bioreagents). Species reactivity: MA3-925 detects RyR1 and RyR2 isoforms in bovine, canine, mouse, rabbit, rat, and sheep.

\section{Anti-FKBP12 Ab (C-19)}

For the detection of FKBP12 and FKBP12.6 isoforms, affinity purified goat polyclonal antibody raised against peptide derived from the C-terminus of human FKBP12 was used (Santa Cruz Biotechnology). Species reactivity: C-19 detects FKBP12 and, to a lesser extent, FKBP12.6 of human, mouse, rabbit, and rat origin.

\section{Anti-FKBP12 Ab (SA-169)}

For the detection of rabbit FKBP12.6 in co-immunoprecipitation experiments, IgG purified from rabbit polyclonal anti-serum was used. Immunization and bleeding were performed by Eurogentec (Hestal/Belgium) on demand of our laboratory. Species reactivity: SA-169 detects FKBP12.6 and FKBP12 of rabbit and human origin.

\section{Anti-Calsequestrin Ab (PA1-913)}

For the detection of calsequestrin, affinity purified rabbit polyclonal antibody raised against purified canine cardiac calsequestrin was used (Affinity Bioreagents). Species reactivity: PA1-913 detects cardiac and skeletal muscle calsequestrin from canine, human, mouse, rabbit, rat, and sheep tissues.

\section{$\underline{\text { Anti-GST Ab }}$}

For the detection of GST-tagged fusion proteins, affinity purified goat polyclonal antibody was used (Amersham/Freiburg).

\section{Secondary Ab (horse radish peroxidase conjugated):}

sheep anti-mouse whole Ig, Amersham/Freiburg;

donkey anti-rabbit whole Ig, Amersham/Freiburg;

rabbit anti-goat affinity-purified IgG, Dako/Copenhagen, Denmark;

donkey anti-mouse affinity-purified lgG, Affinity Bioreagents.

\subsection{Enzymes and nucleotides}

AmpliTaqGold ${ }^{\mathrm{TM}}$ Taq polymerase

Roche/Mannheim 
Collagenase type CLSII

Protease XIV

Trypsin, Sequencing Grade, Modified

dNTP master mix
Biochrom/Berlin

Sigma/München

Promega/Mannheim

Bioline/Luckenwalde

\subsection{Detection, purification and synthesis systems (kits)}

RNeasy Mini Kit, Qiagen/Hilden

SuperScript ${ }^{\mathrm{TM}}$ First-Strand Synthesis System for RT-PCR, Gibco/Karlsruhe

BCA Protein Assay, Pierce/Bonn

SuperSignal ${ }^{\circledR}$ West Pico Chemiluminescent Substrate, Pierce/Bonn

Silver Staining Kit, Protein, Amersham/Freiburg

\subsection{Stock solutions}

The stock solutions were prepared using $\mathrm{ddH}_{2} \mathrm{O}$; the $\mathrm{pH}$ values were adjusted at room temperature.

\section{APS $10 \%$}

For $10 \mathrm{ml} \quad$ Final concentration
APS
$1 \mathrm{~g}$
$10 \%$

The solution was dispensed into $100 \mu \mathrm{l}$ aliquots and stored at $-20^{\circ} \mathrm{C}$.

EDTA $100 \mathrm{mM}$

$\begin{array}{lll} & \text { For } 100 \mathrm{ml} & \text { Final concentration } \\ \text { EDTA (disodium salt) } & 3.723 \mathrm{~g} & 100 \mathrm{mM}\end{array}$

$\mathrm{pH}$ was adjusted with $\mathrm{NaOH}$ to 8.0 . The solution was sterile filtered and stored at $4^{\circ} \mathrm{C}$.

EGTA $100 \mathrm{mM}$

For $100 \mathrm{ml} \quad$ Final concentration

$\begin{array}{lll}\text { EGTA } & 3.804 \mathrm{~g} & 100 \mathrm{mM}\end{array}$

$\mathrm{pH}$ was adjusted with $\mathrm{NaOH}$ to 8.0 . The solution was sterile filtered and stored at $4^{\circ} \mathrm{C}$. 
Glucose $2 \mathrm{M}$

For $100 \mathrm{ml}$

Final concentration

Glucose

$36.4 \mathrm{~g}$

$2 \mathrm{M}$

The solution was sterile filtered, dispensed into aliquots and stored at $-20^{\circ} \mathrm{C}$.

$\underline{\text { Na-HEPES } 500 \mathrm{mM}}$

For $11 \quad$ Final concentration

Na-HEPES

$130.15 \mathrm{~g}$

$500 \mathrm{mM}$

$\mathrm{pH}$ was adjusted with $\mathrm{HCl}$ to 7.5 . The solution was sterile filtered and stored at $4^{\circ} \mathrm{C}$.

$\underline{\text { Imidazole } 500 \mathrm{mM}}$

For 1I Final concentration

Imidazole $\quad 34.4 \mathrm{~g} \quad 500 \mathrm{mM}$

$\mathrm{pH}$ was adjusted with $\mathrm{HCl}$ to 6.9. The solution was sterile filtered and stored at $4^{\circ} \mathrm{C}$.

Magnesium chloride $1 \mathrm{M}$

$\begin{array}{lll} & \text { For } 100 \mathrm{ml} & \text { Final concentration } \\ \mathrm{MgCl}_{2} \times 6 \mathrm{H}_{2} \mathrm{O} & 20.33 \mathrm{~g} & 1 \mathrm{M}\end{array}$

The solution was sterile filtered, dispensed into aliquots and stored at $-20^{\circ} \mathrm{C}$.

$\underline{\text { PBS 10X }}$

$\begin{array}{lll} & \text { For 1 I } & \text { Final concentration } \\ \mathrm{NaCl} & 81.82 \mathrm{~g} & 1.4 \mathrm{M} \\ \mathrm{KCl} & 2 \mathrm{~g} & 27 \mathrm{mM} \\ \mathrm{Na}_{2} \mathrm{HPO}_{4} & 14.2 \mathrm{~g} & 100 \mathrm{mM} \\ \mathrm{KH}_{2} \mathrm{PO}_{4} & 2.45 \mathrm{~g} & 18 \mathrm{mM} \\ \mathrm{pH} \text { was adjusted with } \mathrm{HCl} \text { to } 7.3 . \text { The solution was sterile filtered and stored at room } \\ \text { temperature. }\end{array}$

Na-PIPES $500 \mathrm{mM}$

For 1I Final concentration

Na-PIPES

$162.15 \mathrm{~g}$

$500 \mathrm{mM}$

$\mathrm{pH}$ values of different solutions were adjusted with $\mathrm{HCl}$ to 7.0 and 7.3. The solutions were sterile filtered and stored at $4^{\circ} \mathrm{C}$. 
$\underline{\mathrm{K}_{2}}$-PIPES $500 \mathrm{mM}$

$\begin{array}{lll} & \text { For 1 I } & \text { Final concentration } \\ \mathrm{K}_{2} \text {-PIPES } & 189.25 \mathrm{~g} & 500 \mathrm{mM}\end{array}$

$\mathrm{pH}$ values of different solutions were adjusted with $\mathrm{HCl}$ to $6.8,6.9$, and 7.0. The solutions were sterile filtered and stored at $4^{\circ} \mathrm{C}$.

Potassium chloride $2 \mathrm{M}$

$\begin{array}{lll} & \text { For 1 I } & \text { Final concentration } \\ \mathrm{KCl} & 149.12 \mathrm{~g} & 2 \mathrm{M}\end{array}$

The solution was sterile filtered and stored at room temperature.

SDS $10 \%$

$\begin{array}{lll} & \text { For } 100 \mathrm{ml} & \text { Final concentration } \\ \text { SDS } & 10 \mathrm{~g} & 10 \%\end{array}$

In the case of precipitation of SDS, the solution was warmed until clear.

Sodium chloride $4 \mathrm{M}$

$\begin{array}{lll} & \text { For } 1 \mathrm{I} & \text { Final concentration } \\ \mathrm{NaCl} & 233.76 \mathrm{~g} & 4 \mathrm{M}\end{array}$

The solution was sterile filtered and stored at room temperature.

Sodium fluoride $200 \mathrm{mM}$

$\begin{array}{lll} & \text { For } 100 \mathrm{ml} & \text { Final concentration } \\ \mathrm{NaF} & 0.84 \mathrm{~g} & 200 \mathrm{mM}\end{array}$

The solution was stored in the dark at $4^{\circ} \mathrm{C}$.

Sodium orthovanadate $100 \mathrm{mM}$

$\begin{array}{lll} & \text { For } 100 \mathrm{ml} & \text { Final concentration } \\ \mathrm{Na}_{3} \mathrm{VO}_{4} & 1.84 \mathrm{~g} & 100 \mathrm{mM}\end{array}$

Titration of the solution with $\mathrm{HCl}$ and sequential heating were repeated several times to adjust $\mathrm{pH}$ to 10.0 . The solution was stored in the dark at $4^{\circ} \mathrm{C}$.

Sucrose $2 \mathrm{M}$

Sucrose
For 11

$684.6 \mathrm{~g}$

Final concentration

$2 \mathrm{M}$ 
The solution was dispensed into $20 \mathrm{ml}$ aliquots and stored at $-20^{\circ} \mathrm{C}$.

$\underline{\text { Tris base } 500 \mathrm{mM}}$

For $1 \mathrm{I} \quad$ Final concentration

$\begin{array}{lll}\text { Tris base } & 60.57 \mathrm{~g} & 500 \mathrm{mM}\end{array}$

$\mathrm{pH}$ was adjusted with $\mathrm{HCl}$ to 7.4 . The solution was sterile filtered and stored at $4^{\circ} \mathrm{C}$.

$\underline{\text { Tris- } \mathrm{HCl} 2 \mathrm{M}}$

For $11 \quad$ Final concentration

Tris- $\mathrm{HCl} \quad 315.2 \mathrm{~g} \quad 2 \mathrm{M}$

$\mathrm{pH}$ values of different solutions were adjusted to $\mathrm{pH} 7.4$ and 8.0. The solutions were sterile filtered and stored at $4^{\circ} \mathrm{C}$.

\subsection{Chemicals}

All chemicals used were p. a. quality.

Amersham/Freiburg

Isopropyl- $\beta$-D-thiogalactoside (IPTG)

Biomol/Hamburg

FK506

BioRad/München

Coomassie $^{\circledR}$ Brilliant Blue G-250

BMA/Rockland, USA

SeaKem HE agarose

Invitrogen/Karlsruhe

PBS Dulbecco's, ready-load 100 bp DNA standards, 100X L-glutamine

ISN/Eschwege

Sucrose

Kodak/Paris, France

Developer

Merck/Darmstadt

All usual laboratory chemicals, acetic acid glacial, acetonitrile, glucose, ethanol, methanol, HPLC grade water, $\beta$-propanol, TEMED, trifluoracetic acid 
Roche/Mannheim

5-bromo-4-chloro-3-indolyl-[beta]-D-galactopyranosidecrystal $\quad$ (X-Gal), magnesium chloride solution, 10X PCR buffer

Roth/Karlsruhe

Rotiphorese Gel 30 (30\% acrylamide stock solution with $0.8 \%$ bisacrylamide in proportion $37.5: 1)$, glycine

Sigma/München

All usual laboratory chemicals, adenosine monophosphate (monosodium salt), ammonium hydrocarbonate, butanedione monoxime (BDM), DTT, calcium carbonate, calcium chloride solution, L-carnitine, creatine, ethidium bromide, formalin (37\% solution in $\mathrm{H}_{2} \mathrm{O}$ ), glutaraldehyde, glycerol, $\beta$-glycerophosphate, HEPES and HEPES sodium salt, medium M199, $\beta$-mercaptoethanol, penicillin-streptomycin solution (100X), L- $\alpha-$ phosphatidylcholine from egg yolk, PIPES (monosodium and dipotassium salts), Ponceau S (ready to use solution), silver nitrate, sodium fluoride, sodium orthovanadate, sodium thiosulphate, taurine

Tetanal photowerk/Germany

Fixer solution

\subsection{Detergents}

CHAPS

NP-40

SDS

Triton X-100

Tween 20
Roche/Mannheim

Sigma/München

BioRad/München

Sigma/ München

BioRad München

\subsection{Proteins, protease inhibitors and protein standards}

Aprotinin

Albumin fraction $\mathrm{V}$, bovine

Benzamidine

Bromphenol blue, precision plus protein ${ }^{\mathrm{TM}}$ standards

Calpain inhibitor I

Calpain inhibitor II

FK506-binding protein, human

Glutathione Sepharose 4B
Biomol/Hamburg

Sigma/München

Sigma/München

Biomol/Hamburg

Biomol/Hamburg

Sigma/München

Amersham/Freiburg 
Glutathione S-transferase

Laminin

Leupeptin

Pefabloc SC

Pepstatin A

Protein A-sepharose FF

Protein G-sepharose FF
Sigma/München

Sigma/München

Biomol/Hamburg

Biomol/Hamburg

Biomol/Hamburg

Amersham/Freiburg

Amersham/Freiburg

\subsection{Other materials}

Culture dishes (35 and $100 \mathrm{~mm}$ ), serological pipettes $(2,5,10,25 \mathrm{ml})$, transfer pipettes, Sarstedt/Germany

Nitrocellulose Transfer Membrane, $0.45 \mu \mathrm{m}$, PROTRAN $^{\circledR}$, Whatman 3MM paper, Schleicher and Schuell/Dassel

GSTrap $^{\mathrm{TM}} \mathrm{FF}$ prepacked with $1 \mathrm{ml}$ glutathione-sepharose HiTrap ${ }^{\mathrm{TM}}$ columns, Amersham/Freiburg

Pipette tips, Brand/Wertheim

Polyallomer thin-walled centrifuge tubes $(14 \times 89$ and $25 \times 89 \mathrm{~mm})$, polycarbonate centrifuge tubes $(0.5 \mathrm{ml})$ Beckman/München

Screw lid polycarbonate centrifuge tubes $(16 \times 76 \mathrm{~mm}$ and $38 \times 102 \mathrm{~mm})$, Kontron/Neufahrn

Sorvall ${ }^{\circledR}$ polycarbonate centrifuge bottles $(50 \mathrm{ml})$, Sorvall ${ }^{\circledR}$ centrifuge bottles $(250 \mathrm{ml})$ Kendro Laboratory Products/Hanau

Sterile filter pipette tips, Biozym/Oldendorf

Sterile filter, $0.2 \mu \mathrm{m}$, Centricon ${ }^{\circledR}$ concentrators (MWCO 30000 and $100000 \mathrm{Da}$ ), Millipore/Eschborn

Spectra/Por DispoDialyser dialysis bags (MWCO 1000 and 100000 Da), Spectrum/Lohmar

Safe-Lock tubes (0.2, 0.5, 1.5 and $2 \mathrm{ml})$, Eppendorf/Hamburg 
Vivaspin 20 concentrators (MWCO 100000 Da), Sartorius/Göttingen

X-ray films, Fuji/Düsseldorf

\subsection{Instruments}

Automatic pipettes, type Reference ${ }^{\circledR}$, Eppendorf/Hamburg

Automatic pipettes, type PreCision, Biozym/Oldendorf

Automatic pipettes, type Pipetman, Gilson/Bad Camberg

Centrifuges and rotors:

\begin{tabular}{|c|c|}
\hline \multicolumn{2}{|c|}{ Bench-top, high speed and ultracentrifuges } \\
\hline $\begin{array}{l}\text { Eppendorf bench-top centrifuge, type MiniSpin } \\
5415 \mathrm{C} \\
\text { Eppendorf centrifuge } 5810 \mathrm{R}\end{array}$ & Eppendorf/Hamburg \\
\hline Laborcentrifuge $3 \mathrm{~K} 12$ & Sigma/München \\
\hline Megafuge $2.0 \mathrm{R}$ & Heraeus Instruments/Hanau \\
\hline Sorvall $^{\circledR}$ high speed centrifuge, Evolution ${ }_{R C}$ & Kendro/Hanau \\
\hline $\begin{array}{l}\text { Ultracentrifuge L-70 } \\
\text { Ultracentrifuge TL-100, bench-top model }\end{array}$ & Beckman/München \\
\hline Rotors for high speed and ult & acentrifuges \\
\hline $\begin{array}{l}\text { Sorvall }^{\circledR} \mathrm{SS} 34, \mathrm{~g}_{\max }=50228 \\
\text { Sorvall }^{\circledR} \mathrm{SLA} 1500, \mathrm{~g}_{\max }=35793\end{array}$ & Kendro/Hanau \\
\hline $\begin{array}{l}\text { Centricon }{ }^{\circledR} \mathrm{TFT} 45.94, \mathrm{~g}_{\max }=234800 \\
\text { Centricon }{ }^{\circledR} \mathrm{TFT} 75, \mathrm{~g}_{\max }=515000 \\
\text { (both are compatible with Beckman L-70) }\end{array}$ & Kontron Instruments/Neufahrn \\
\hline $\begin{array}{l}\text { Ti } 94, g_{\max }=694000 \\
\text { TLA-120.1 } g_{\max }=627000 \\
\text { SW27, } g_{\max }=141000 \\
\text { SW41, } g_{\max }=288000\end{array}$ & Beckman/München \\
\hline
\end{tabular}

Easy-Cast ${ }^{\mathrm{TM}}$ Electrophoresis system for DNA electrophoresis, model \#B1, peqlab/Erlangen

Electrophoresis apparatus, type Mini-Protean ${ }^{\circledR}$ II, BioRad/München

Electroblotting apparatus, type Mini Trans-Blot ${ }^{\circledR}$, BioRad/München 
Electroporator, model EasyjecT, EquiBio/Needham Heights, USA

End-over-end rotator, Heto Lab Equipment/Denmark

Eppendorf BioPhotometer, Eppendorf/Hamburg

Fraction collector, FRAC-100, Amersham/Freiburg

Gas controlled incubators "Function Line", Heraeus/Hanau

Gradient former, model J50, Jule, Inc/Milford, USA

Ice machine, Ziegra/Isernhagen

Incubator with shaking for cell culture, model $\mathrm{CH}-4103$, Infors AG/Bottmingen

Magnetic mixer with warming, type M21/1 Framo-Gerätetechnik/Germany

Microcomputer electrophoresis power supply, Consort E425

Microscope Olympus, CK-40, Olympus Optical Co., LTD/Japan

Microwave oven, Siemens/Germany

Multilmage Light Cabinet with built-in ultraviolet emitter and video camera, Alpha Innotech Corporation. The instrument is used for documentation of $\mathrm{X}$-ray films and gels

Peristaltic pump P-1, Amersham/Freiburg

pH-Meter 761 Calimatic, Knick/Berlin

Plate reader $\mathrm{KC} 4, \mathrm{BIO}-\mathrm{TEK}^{\circledast}$ Instruments, inc./USA

Rocking platform, KMA, Edmund Bühler/Tübingen

Savant Speed Vac ${ }^{\circledR}$ concentrator, ThermoLife Sciences/Egelsbach

Shaker for cell culture, model 3015, GFL/Burgwedel

Sonopuls homogenizer HD2070, Bandelin/Berlin

Sterile bench, class II, Clean Air/Hilden

Sterile bench, 2F 120-II GS, Integra Biosciences/Fernwald

Thermocycler, type Mastercycler ${ }^{\circledR}$ gradient, Eppendorf/Hamburg

Thermomixer 5436, Eppendorf/Hamburg

Thermostat, Heraeus/Hanau

UV/Visible spectrophotometer, Ultrospec 3000, Amersham Biosciences/Freiburg 
Ultraviolet emitter, 312 nm, Bachofer/Reutlingen

Vortex, Genie $2^{\mathrm{TM}}$, Bender and Hobein AG/Zurich

Video-edge detection system/Crescent Electronics

Waring Commercial ${ }^{\circledR}$ laboratory blender with built-in timer and 1 I glass beaker equipped with blades, neoLab/Heidelberg

Water bath 1083, GFL/Burgwedel

X-ray film cassettes $10 \times 18$, Siemens/Germany 


\section{METHODS}

\subsection{Cell biology methods}

\subsubsection{Isolation of rabbit ventricular myocytes}

The isolation of primary rabbit ventricular cardiomyocytes was performed using retrograde Langendorff perfusion followed by enzymatic digestion.

\section{Heart perfusion}

Retrograde perfusion of the heart: after excision of the heart, a canula was inserted into the aorta and perfusion started with $500 \mathrm{ml}$ oxygen-gassed Tyrode-calcium solution at a flow rate of $30 \mathrm{ml} / \mathrm{min}$ until the heart beating stabilized. To disrupt calcium-dependent adhesion, $400 \mathrm{ml}$ of Tyrode $\mathrm{Ca}^{2+}$-free solution was run until full stop of the heart. To break down components of extracellular matrix, the heart was digested with enzyme solution until it started to feel soft (about 15 minutes, depending on the size of the heart). Subsequently, stop solution was added to stop collagenase action.

Before and during perfusion, all solutions used (except for the stop solution) were pregassed with $\mathrm{O}_{2}$ in a perfusor syringe, from which they were directed into the aorta.

\section{Preparation of cardiomyocyte suspension}

After perfusion of the heart, atria and connective tissue were removed and ventricles were transferred into a glass beaker filled with flowthrough of the stop solution. Further disruption of the tissue was performed mechanically. To obtain a cell suspension, the tissue was cut until the solution became cloudy. The suspension was then poured through a nylon mesh.

Non-myocytes and dead myocytes were removed by numerous steps of selective sedimentation under gravity (for about 10 minutes) in pre-gassed washing solution. Each portion of washing solution used for every subsequent sedimentationresuspension cycle contained calcium at a gradually rising concentration, reaching in the final washing solution molarity $(1 \mathrm{mM})$ which is close to that in the medium (1.8 $\mathrm{mM})$ used for further cell culture. After the last sedimentation step, cardiomyocytes were suspended in M199 supplemented with albumin. Typically, the cell suspension had a density of about $0.5 \times 10^{6} \mathrm{cells} / \mathrm{ml}$. 
Media and solutions used for cardiomyocyte isolation and culture

All media and solutions used for cell preparation and culture were prepared in double distilled water, further purified by sterile filtration and stored at $4^{\circ} \mathrm{C}$.

10X Tyrode stock solution

\begin{tabular}{lll}
\hline & For $1 \mathrm{I}$ & Final concentration \\
$\mathrm{NaCl}$ & $80.06 \mathrm{~g}$ & $1.37 \mathrm{M}$ \\
$\mathrm{KCl}$ & $4.03 \mathrm{~g}$ & $54 \mathrm{mM}$ \\
$\mathrm{MgSO}_{4} \times 7 \mathrm{H}_{2} \mathrm{O}$ & $2.96 \mathrm{~g}$ & $12 \mathrm{mM}$ \\
$\mathrm{Na}_{2} \mathrm{HPO}_{4} \times 12 \mathrm{H}_{2} \mathrm{O}$ & $4.3 \mathrm{~g}$ & $12 \mathrm{mM}$ \\
$\mathrm{HEPES}$ & $47.66 \mathrm{~g}$ & $200 \mathrm{mM}$ \\
$\mathrm{ddH}_{2} \mathrm{O}$ & to $1 \mathrm{I}$ & \\
pH was adjusted with $\mathrm{NaOH}$ to 7.54. & &
\end{tabular}

1X Tyrode solution with calcium

$\begin{array}{lll} & \text { For } 1 \mathrm{I} & \text { Final concentration } \\ 10 \times \mathrm{Tyrode} \text { solution } & 100 \mathrm{ml} & 1 \mathrm{X} \\ 1 \mathrm{M} \mathrm{CaCl}_{2} \text { (Sigma) } & 1 \mathrm{ml} & 1 \mathrm{mM} \\ \text { Glucose } & 2.74 \mathrm{~g} & 14.98 \mathrm{mM} \\ \mathrm{ddH}_{2} \mathrm{O} & \text { to } 1 \mathrm{I} & \end{array}$

$\underline{1 X \text { Tyrode solution without calcium }}$

\begin{tabular}{llll}
\hline & & For $2 \mathrm{I}$ & Final concentration \\
10X Tyrode stock solution & $200 \mathrm{ml}$ & $1 \mathrm{X}$ \\
Glucose & $5.4 \mathrm{~g}$ & $14.98 \mathrm{mM}$ \\
100X pen/strep solution & $20 \mathrm{ml}$ & $1 \mathrm{X}$ \\
$\mathrm{ddH}_{2} \mathrm{O}$ & to $2 \mathrm{I}$ & \\
$\mathrm{pH}$ was adjusted with $\mathrm{NaOH}$ to 7.54. & &
\end{tabular}

Enzyme solution (prepared directly prior to isolation)

Final concentration

$\begin{array}{lll}\text { 1X Tyrode solution without } \mathrm{Ca}^{2+} & 80 \mathrm{ml} & \\ \text { Taurine } & 600 \mathrm{mg} & 60 \mathrm{mM} \\ \text { DL-Glutamic acid } & 94 \mathrm{mg} & 8 \mathrm{mM} \\ \text { DL-Carnitine } & 31 \mathrm{mg} & 2 \mathrm{mM}\end{array}$


Collagenase 2 (357 U/mg)

Protease XIV

$1 \mathrm{M} \mathrm{CaCl}_{2}$

$\mathrm{pH}$ was adjusted with $\mathrm{NaOH}$ to 7.54 .

Stop solution (with $2 \%$ albumin)
$2.1 \mathrm{mg}$

$2 \mu \mathrm{l}$
Final concentration

1X Tyrode solution without calcium

$1 \mathrm{M} \mathrm{CaCl}_{2}$

Albumin fraction $\mathrm{V}$

BDM
$300 \mathrm{ml}$

$15 \mu \mathrm{l}$

$0.05 \mathrm{mM}$

$6 \mathrm{~g}$

$607 \mathrm{mg}$
$20 \mathrm{mM}$

$\mathrm{pH}$ was adjusted with $\mathrm{NaOH}$ to 7.54 ; the solution was dispensed into $50 \mathrm{ml}$ aliquots and stored at $-20^{\circ} \mathrm{C}$.

\begin{tabular}{|c|c|c|c|c|c|}
\hline Washing solution & $\# 1^{*}, 2,3$ & $\# 4$ & $\# 5$ & $\# 6$ & $\# 7$ \\
\hline 1X Tyrode solution & $40 \mathrm{ml}$ & $25 \mathrm{ml}$ & $25 \mathrm{ml}$ & $25 \mathrm{ml}$ & $25 \mathrm{ml}$ \\
\hline $1 \mathrm{M} \mathrm{CaCl}_{2}$ & $\begin{array}{c}2 \mu \mathrm{l} \\
(0.05 \mathrm{mM})\end{array}$ & $\begin{array}{c}3.12 \mu \mathrm{l} \\
(0.125 \mathrm{mM})\end{array}$ & $\begin{array}{c}6.25 \mu \mathrm{l} \\
(0.25 \mathrm{mM})\end{array}$ & $\begin{array}{c}12.5 \mu \mathrm{l} \\
(0.5 \mathrm{mM})\end{array}$ & $\begin{array}{c}25 \mu \mathrm{l} \\
(1 \mathrm{mM})\end{array}$ \\
\hline
\end{tabular}

$81 \mathrm{mg}$ of BDM was added to washing solution \# 1

M199 media with additives

M199 media (Sigma, \#M7528) $500 \mathrm{ml}$

Taurine $312.5 \mathrm{mg}$

L-Carnitine $500 \mathrm{mg}$

Creatine $327.5 \mathrm{mg}$

100X pen/strep

$5 \mathrm{ml}$

100X L-glutamine

$5 \mathrm{ml}$

M199 media with $6 \%$ albumin

M199 media with all additives

$500 \mathrm{ml}$

Albumin fraction $\mathrm{V}$

$30 \mathrm{~g}$ 
Antibiotics

Penicillin-streptomycin solution (100X), containing 10000 units $/ \mathrm{ml}$ penicillin and 10 $\mathrm{mg} / \mathrm{ml}$ streptomycin in $0.9 \% \mathrm{NaCl}$, was used at a quantity of $10 \mathrm{ml} / \mathrm{l}$.

\subsubsection{Primary culture of adult rabbit ventricular cardiomyocytes}

Preparation of laminin culture dishes: prior to plating the cells, culture dishes were coated with laminin to provide better attachment of the cells to the bottom. Dishes of different sizes were used depending on the application.

$\begin{array}{lll} & \text { For } 100 \mathrm{~mm} \text { dish } & \text { For } 35 \mathrm{~mm} \text { dish } \\ \text { M199 } & 3 \mathrm{ml} & 170 \mu \mathrm{l} \\ \text { Laminin }(1 \mathrm{mg} / \mathrm{ml}) & 30 \mu \mathrm{l} & 1.7 \mu \mathrm{l}\end{array}$

The dishes were covered with M199/laminin mixture and incubated at $37^{\circ} \mathrm{C}$ for $1 \mathrm{~h}$ before use.

Immediately after isolation, cells were plated on laminin-coated culture dishes. The culture of the cardiomyocytes was performed on dishes of different size and at different cell numbers depending on the type of application:

\begin{tabular}{|c|c|c|}
\hline Application & $\begin{array}{c}\text { Cell number plated in the } \\
\text { volume of M199 medium }\end{array}$ & $\varnothing$ of the culture dish \\
\hline Cell shortening measurements & $5 \times 10^{4} / 1 \mathrm{ml}$ & $35 \mathrm{~mm}$ \\
Protein isolation & $5 \times 10^{5} / 5 \mathrm{ml}$ & $100 \mathrm{~mm}$ \\
RNA isolation & $5 \times 10^{5} / 5 \mathrm{ml}$ & $100 \mathrm{~mm}$ \\
\hline
\end{tabular}

After the attachment phase of 3 hours, the medium was replaced with fresh M199 (2 ml per 35 and $10 \mathrm{ml}$ per $100 \mathrm{~mm}$ dishes). Depending on the application, the culture time was either 24 or 48 hours. The incubation of the cardiomyocytes was performed in gas-controlled incubators in water vapor saturated air containing $5 \% \mathrm{CO}_{2}$ at $37^{\circ} \mathrm{C}$.

\subsubsection{Harvesting of cardiomyocytes}

After the desired culture time, $100 \mathrm{~mm}$ dishes with cells were taken from the incubator and medium was sucked off and $5 \mathrm{ml}$ of PBS (Invitrogen) was added. The cells were scraped with a disposable scraper and transferred to $15 \mathrm{ml}$ tubes. After sedimentation at $472 g_{\max }$ for 5 minutes, the supernatants were discarded and pellets were 
immediately frozen in liquid nitrogen and stored at $-80^{\circ} \mathrm{C}$ until RNA isolation (3.2.1) or protein homogenate preparation (3.4.1).

\subsection{Molecular biology methods}

\subsubsection{RNA isolation from rabbit cardiomyocytes}

The isolation of total RNA, used in RT-PCR, was conducted using the RNeasy Mini Kit (QIAGEN) in accordance to the RNeasy Mini protocol for isolation of total RNA from animal cells.

$5 \times 10^{5}$ cells were plated on each $100 \mathrm{~mm}$ culture dish. After harvesting and freezing the cells as described above, the pellets were suspended in $350 \mu$ of RLT buffer with freshly added $\beta$-mercaptoethanol. The cells were homogenized by vortexing. For further efficient homogenization, lysates were pipetted directly onto QIAshredder columns, sitting in $2 \mathrm{ml}$ collection tubes, and centrifuged for $2 \mathrm{~min}$ at maximum speed of an Eppendorf bench-top MiniSpin centrifuge. 1 volume $(350 \mu \mathrm{l})$ of $70 \%$ ethanol was added to each homogenized lysate. $700 \mu$ of each sample was applied to an RNeasy mini spin column, sitting in a $2 \mathrm{ml}$ collection tube, and centrifuged for 15 seconds at $8000 \mathrm{~g}$. To wash the column, $700 \mu$ l of RW1 buffer was pipetted onto RNeasy column followed by centrifugation for 15 seconds at $8000 \mathrm{~g}$. To continue washing, $500 \mu \mathrm{l}$ of RPE buffer with added ethanol was pipetted onto the RNeasy column with following centrifugation for 15 seconds at $8000 \mathrm{~g}$. To dry the RNeasy membrane, $500 \mu \mathrm{l}$ of RPE buffer was applied and the columns were centrifuged for 2 minutes at maximum speed of an Eppendorf bench-top MiniSpin centrifuge. To elute the RNA, $50 \mu$ l of RNase-free water was pipetted directly onto the RNeasy membrane and columns were centrifuged for 1 minute at $8000 \mathrm{~g}$. After elution, the RNA-containing samples were concentrated in a speed vac concentrator at room temperature until the volume of samples was reduced to $10 \mu \mathrm{l}$.

To determine the concentration and purity of the RNA obtained, the extinction at $260 \mathrm{~nm}$ and $280 \mathrm{~nm}$ was measured. The ratio of the OD at $260 \mathrm{~nm}$ and at $280 \mathrm{~nm}$ served as a measure of RNA purity. In a protein-free solution, the ratio $O D_{260} / O D_{280}$ is 2 . Due to minor protein contaminations this coefficient is usually somewhat lower. In our experiments it was typically higher than 1.8.

\section{Solutions used for RNA isolation}

All solutions used for RNA isolation were provided in the RNeasy Mini Kit (QIAGEN) and their composition is not described. 
$\underline{\text { RLT buffer }}$

RLT buffer (QIAGEN)

$1000 \mu \mathrm{l}$

$\beta$-Mercaptoethanol

$10 \mu \mathrm{l}$

$\underline{\text { RPE buffer }}$

RPE buffer (QIAGEN)

1 volume

Ethanol (absolute)

4 volumes

\subsection{2 cDNA synthesis}

For the synthesis of cDNA, a SuperScript ${ }^{T M}$ first-strand Synthesis System for RT-PCR (Life Technology) was used. The protocol for first-strand synthesis using random primers was utilized.

At first, RNA/primer mixture comprised of the following components was prepared: $0.21 \mu \mathrm{g}$ of total RNA prepared from rabbit ventricular cardiomyocytes, $2 \mu \mathrm{l}$ of random hexamers $(50 \mathrm{ng} / \mu \mathrm{l})$, and $1 \mu \mathrm{l}$ of $10 \mathrm{mM}$ dNTP mix were mixed in $10 \mu \mathrm{l}$ volume adjusted with DEPS-treated water. To denature RNA secondary structures, the mixture was incubated for 5 minutes at $65^{\circ} \mathrm{C}$ and chilled on ice for 1 minute. Then $9 \mu$ of a cDNA synthesis reaction mixture, comprised of $2 \mu \mathrm{l}$ of $10 \mathrm{X}$ RT buffer, $4 \mu \mathrm{l}$ of $25 \mathrm{mM} \mathrm{MgCl}$, $2 \mu \mathrm{l}$ of $0.1 \mathrm{M}$ DTT, and $1 \mu \mathrm{l}$ of ribonuclease inhibitor, was added. The whole reaction mixture was incubated for 2 minutes at $25^{\circ} \mathrm{C}$. Finally $1 \mu \mathrm{l}$ of SuperScript II RT was added and the mixture was incubated for 10 minutes at $25^{\circ} \mathrm{C}$ followed by incubation for 50 minutes at $42^{\circ} \mathrm{C}$. Then the mixture was incubated for 15 minutes at $70^{\circ} \mathrm{C}$ and chilled on ice. To degrade all RNA, $1 \mu$ of RNase $\mathrm{H}$ was added and the mixture was incubated for 20 minutes at $37^{\circ} \mathrm{C}$.

$\underline{\text { RNA/primer mixture }}$

$0.21 \mu \mathrm{g}$ total RNA

$2 \mu \mathrm{l}$ random $50 \mathrm{ng} / \mu \mathrm{l}$ hexamers

$1 \mu \mathrm{l} 10 \mathrm{mM}$ dNTP mix

DEPS-treated water

cDNA synthesis reaction mixture

$2 \mu l$ 10X RT buffer

$4 \mu \mathrm{l} 25 \mathrm{mM} \mathrm{MgCl}_{2}$

$2 \mu \mathrm{l} 0.1 \mathrm{M}$ DTT

$1 \mu \mathrm{l}$ RaseOUT recombinant ribonuclease inhibitor 


\subsubsection{Polymerase chain reaction (PCR)}

The polymerase chain reaction allows to amplify fragments due to repetitive cycles of DNA synthesis (Fig. 5). The reaction uses two specific synthetic oligonucleotides (primers), that hybridize to sense and antisense DNA strands of the DNA fragment to be amplified, four deoxyribonucleotide triphosphates (dNTP's) and a heat-stable DNA polymerase. Each cycle consists of three reactions that take place under different temperatures. First, the double-stranded DNA is converted into its two single strands (denaturation at $95^{\circ} \mathrm{C}$ ). They serve as templates for the synthesis of new DNA. After heating, the reaction is cooled $\left(45-60^{\circ} \mathrm{C}\right)$ to allow the annealing (hybridization) of primers to the complementary DNA strands. Starting from the primers, DNA polymerase extends both DNA strands at $72^{\circ} \mathrm{C}$ (DNA synthesis) (Figure 5A). Since the DNA molecules synthesized in each cycle can serve as a template in the next cycle, the number of target DNA copies approximately doubles every cycle. Already after the third cycle double stranded DNA molecules of the size corresponding to the distance between two primers are synthesized (Figure 5B). The repeating cycles of heating and cooling take place in a thermocycler.

The PCR reaction was performed with FKBP12-, GAPDH- and calsequestrin-specific primers. The PCR lasted for 30 cycles in the case of FKBP12 and 28 cycles in the case of GAPDH/calsequestrin duplex under the following conditions:

\section{45 seconds denaturation at $94^{\circ} \mathrm{C}$}

2. 45 seconds annealing at $54^{\circ} \mathrm{C}$ or $57^{\circ} \mathrm{C}$ for $\mathrm{FKBP} 12$ or $\mathrm{GAPDH} /$ calsequestrin, respectively

3. 60 seconds at $72^{\circ} \mathrm{C}$ DNA synthesis

The denaturation step at $95^{\circ} \mathrm{C}$ before the first cycle was extended for 2 minutes. After the last cycle, the synthesis step was prolonged for 7 minutes to finish synthesis of incompletely synthesized DNA strands.

The PCR was performed with the ampliTaqGold ${ }^{\mathrm{TM}}$ Taq DNA polymerase $(5 \mathrm{U} / \mu \mathrm{l})$ (Roche). The specific buffers and solutions were received with the polymerase. dNTP master mix from Bioline was used. 


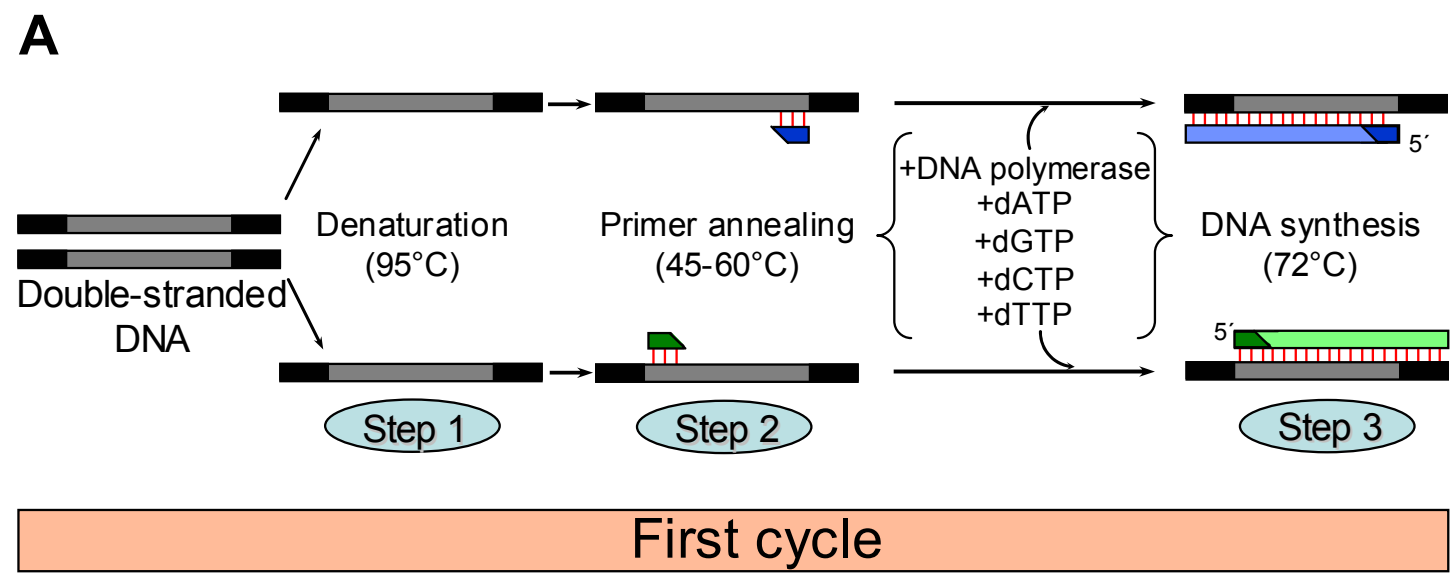

B

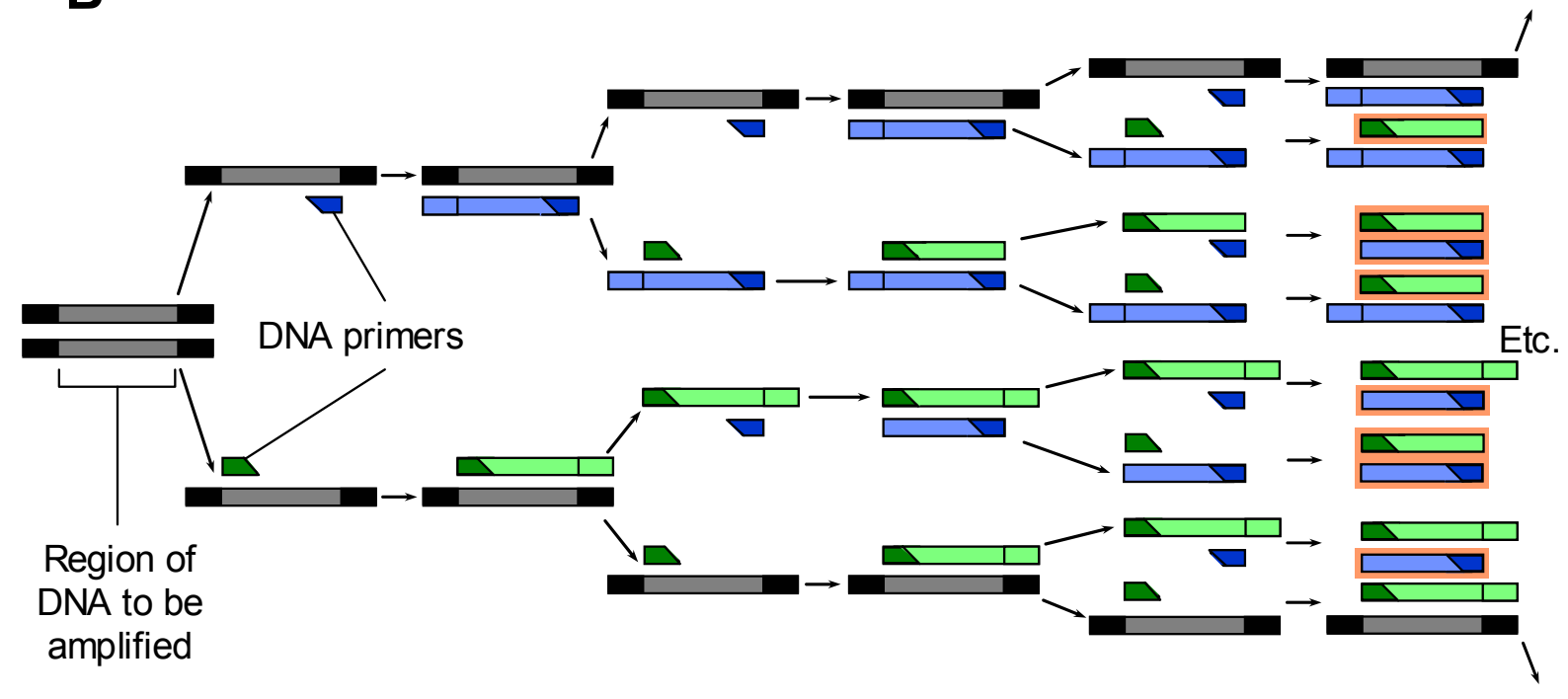

\section{First cycle $\quad$ Second cycle $\quad$ Third cycle}

Figure 5. Schematic representation of the PCR. (A) After strand separation (step 1), cooling of the DNA allows primers to hybridize to complementary sequences in the two DNA strands (step 2). In the presence of DNA polymerase and the four dNTPs, DNA is synthesized, starting from the two primers (step 3). (B) In the example illustrated, three cycles of reaction produce 16 DNA chains, 8 of each (boxed in orange) are the same length as and correspond exactly to one or the other strand of the original bracketed sequence shown at the far left; the other strands contain extra DNA downstream of the original sequence, which is replicated in the first few cycles. After several more cycles, essentially all of the DNA strands have this unique length. 


\section{PCR reaction mixture:}

$4 \mu \mathrm{l}$ 10X PCR buffer (500 mM Tris-HCl pH 9.1, $\left.140 \mathrm{mM}\left(\mathrm{NH}_{4}\right)_{2} \mathrm{SO}_{4}\right)$

$2 \mu \mathrm{l} \mathrm{MgCl}_{2}(25 \mathrm{mM})$

$1 \mu \mathrm{l} 100 \mathrm{mM}$ dNTP mix ( $25 \mathrm{mM}$ of each dATP, dCTP, dGTP, dTTP)

$2 \mu$ template (cDNA) obtained as described above

$2 \mu \mathrm{l}(8 \mathrm{pmol})$ forward primer

$2 \mu \mathrm{l}(8 \mathrm{pmol})$ reverse primer

$0.5 \mu \mathrm{l} \mathrm{Taq}$ polymerase (2.5 units)

$50 \mu \mathrm{l}$ volume was adjusted with sterile $\mathrm{ddH}_{2} \mathrm{O}$

To check the size of the PCR product, an $8 \mu \mathrm{l}$ aliquot of the PCR reaction was electrophoretically analyzed in a $1.5 \%$ agarose gel.

\section{Electrophoresis conditions}

For preparation of a $1.5 \% \mathrm{gel}, 1.2 \mathrm{~g}$ of agarose was dissolved by heating in $80 \mathrm{ml}$ of $0.5 \mathrm{X}$ TBE buffer. For visualization of the bands, $1.5 \mu \mathrm{l}$ of ethidium bromide $(10 \mathrm{mg} / \mathrm{ml})$ was added to the mixture. After mixing, the gel was poured into the prepared gel plate. In the mean time of the polymerization, the samples were prepared for loading by mixing of $8 \mu$ of DNA probe with $2 \mu$ of $5 X$ loading buffer.

After polymerization, the gel was placed into an electrophoresis chamber filled with $0.5 \mathrm{X}$ TBE buffer, the samples were loaded, and the electrophoresis was performed at $80 \mathrm{~V}$.

\section{UV detection of DNA, intercalating ethidium bromide}

Ethidium bromide is a fluorescent dye which contains a planar group that intercalates between the stacked bases of the DNA. The fixed position of this group and its close proximity to the bases cause dye, bound to DNA, to display an increased fluorescence yield compared to that of the dye in free solution. Ultraviolet radiation at $254 \mathrm{~nm}$ is absorbed by the DNA and transmitted to the dye; radiation at $302 \mathrm{~nm}$ and $366 \mathrm{~nm}$ is absorbed by the bound dye itself. In both cases, the energy is reemitted at $590 \mathrm{~nm}$ in the red orange region of the visible spectrum. Hence, DNA can be visualized under a UV transilluminator. The gel was photographed using a video camera built in the Multilmage Light Cabinet.

\section{$\underline{5 X T B E}$}

For 11

Tris base
Final concentration

$225 \mathrm{mM}$ 
Borate

EDTA

$\mathrm{ddH}_{2} \mathrm{O}$

\section{$\underline{0.5 X \mathrm{TBE}}$}

5X TBE

$\mathrm{dd}_{2} \mathrm{O}$

$\underline{5 X \text { loading buffer }}$

Bromphenol Blue

Glycerol

5X TBE

$\mathrm{ddH}_{2} \mathrm{O}$
$13.99 \mathrm{~g}$

$1.86 \mathrm{~g}$

to 1 ।

\section{For 11}

$100 \mathrm{ml}$

to 1 I

For $10 \mathrm{ml}$

Final concentration

$20 \mathrm{mg}$

$5 \mathrm{ml}$

$0.2 \%$

$1 \mathrm{ml}$

$50 \%$

to $10 \mathrm{ml}$
$225 \mathrm{mM}$

$5 \mathrm{mM}$

The buffer was stored at $4^{\circ} \mathrm{C}$.

\subsubsection{Adenoviral transfection of isolated rabbit ventricular cardiomyocytes}

For transfection of cardiomyocytes, adenovirus-mediated gene transfer was used. The replication of DNA-containing adenoviruses occurs epichromosomally, which makes them a system of choice to study gene expression in primary non-replicative cells, which the cardiomyocytes are. The recombinant adenoviruses coding for $\beta$-galactosidase, full size human FKBP12, and FKBP12.6 were generated in our laboratory.

The cells were transfected immediately after preparation directly in the suspension. In the transfection experiments, different amounts of cells were plated on the dishes of different sizes depending on further purposes:

\begin{tabular}{|c|c|c|}
\hline Application & $\begin{array}{c}\text { Number of cells plated on one } \\
\text { dish }\end{array}$ & $\varnothing$ of the culture dish \\
\hline $\begin{array}{c}\text { Cell shortening } \\
\text { measurements }\end{array}$ & $5 \times 10^{4} / 1 \mathrm{ml}$ & $35 \mathrm{~mm}$ \\
\hline $\begin{array}{c}\text { Verification of the transgene } \\
\text { expression on protein level }\end{array}$ & $5 \times 10^{5} / 5 \mathrm{ml}$ & $100 \mathrm{~mm}$ \\
\hline $\begin{array}{c}\text { Verification of transgene } \\
\text { expression on RNA level }\end{array}$ & $5 \times 10^{5} / 5 \mathrm{ml}$ & $100 \mathrm{~mm}$ \\
\hline
\end{tabular}




\section{Calculation of virus quantity taken for transfection}

The amount of virus taken for experiments is expressed as a multiplicity of infection (MOI), which is the number of active viral particles per cell. $\mathrm{MOI}$ of used viruses was calculated based on the virus concentration estimated in plaque test assays and measured in plaque forming units per $\mathrm{ml}$ (pfu/ml). A varying $\mathrm{MOl}$ was used in different experiments depending on the desired level of transgene overexpression.

For the calculation of the amount of virus corresponding to the desired $\mathrm{MOI}$, the following formula was used:

$$
V_{\text {stock }}=\frac{M O I \times a_{c t}}{C_{\text {stock }}}, \text { where }
$$

$a_{c t}-$ total amount of cells to be infected with the virus

$V_{\text {stock }}$ - volume of virus stock to be added

$C_{\text {stock }}$ - concentration of virus in $\mathrm{pfu} / \mu \mathrm{l}$

Transfection for verification of transgene expression at mRNA and protein levels Immediately after isolation, the cell suspension containing $2.5 \times 10^{6}$ cells was devided between 5 tubes $\left(5 \times 10^{5}\right.$ cells per dish in $5 \mathrm{ml}$ of M199). The amounts of virus corresponding to $\mathrm{MOI} 0,1,10,50$ and 100 were taken from the stock solution and pipetted directly into the tubes. After mixing, the cells were plated on $100 \mathrm{~mm}$ culture dishes. After 24 or 48 hours of culture time, the cells were harvested as described before (3.1.3) to proceed with RNA isolation (3.2.1) or preparation of protein lysates (3.4.1).

\section{Transfection for cell shortening measurements}

Immediately after isolation, the cell suspension, containing $3 \times 10^{5}$ cells was suspended in $6 \mathrm{ml}$ of M199 $\left(5 \times 10^{4}\right.$ cells per dish in $1 \mathrm{ml}$ of M199). The amount of virus corresponding to $\mathrm{MOI} 100$ was taken from the viral stock and pipetted directly into the tube. After mixing, the cells were plated on $35 \mathrm{~mm}$ culture dishes and cultured for 24 or 48 hours as described before.

\subsection{5 $\beta$-Galactosidase reporter gene assay}

The detection of $\beta$-galactosidase ( $\beta$-gal) activity in the cells transfected with LacZ virus was performed to estimate the transfection efficiency at different $\mathrm{MOI}$. The 
$\beta$-galactosidase reporter gene assay is based on the enzyme-catalyzed cleavage of X-gal - a specific substrate for $\beta$-gal. The X-gal solution appears originally as a yellow solution which is able to easily pass a membrane barrier due to its lipophilic properties. Once it has entered the cell, $\beta$-gal expressed there cleaves the substrate, converting it into an insoluble blue dye, which precipitates in the cytoplasm and turns the color of the cells into blue. Insolubility of the precipitate makes it unable to leave the cell, leading to a highly precise signal without background, which allows detecting the individual cells expressing a LacZ transgene.

For the verification of transfection efficiency, the cells were transfected with adenovirus coding for $\beta$-galactosidase (LacZ adenovirus) at MOI of $0,1,10,50$ and 100, and plated on $35 \mathrm{~mm}$ culture dishes.

48 hours post transfection, $\beta$-galactosidase reporter gene assay was performed: culture media was removed from the dishes and $1 \mathrm{ml}$ of fixation solution was added on each dish. After 10 minutes of incubation at $37^{\circ} \mathrm{C}$, the fixation solution was removed and cells were washed with $2 \mathrm{ml}$ of PBS. Then $1 \mathrm{ml}$ of staining solution was added per each dish. The cells were incubated at $37^{\circ} \mathrm{C}$ until blue staining had developed (about 1.5 hours). To stop the reaction, the staining solution was removed and the cells were washed with $2 \mathrm{ml}$ of PBS. Finally, dishes were analyzed under the light microscope. To estimate the transfection efficiency, the ratio between total number of cells and transfected cells per field of vision was calculated.

\section{$\underline{\text { Reagents }}$}

Concentration

PBS Dulbecco's (Invitrogen)

Glutaraldehyde

$50 \%$ aqueous solution

X-Gal (5-Bromo-4-chloro-3-indolyl-[beta]- $50 \mathrm{mg} / \mathrm{ml}$ in methanol

D-galactopyranosidecrystal)

$50 \mathrm{mM}$ potassium ferrocyanide

$21.25 \mathrm{mg} / \mathrm{ml}$ in PBS

$50 \mathrm{mM}$ potassium ferricianide

$16.5 \mathrm{mg} / \mathrm{ml}$ in PBS

$\underline{\text { Fixation solution }}$

PBS (Invitrogen) $\quad 10 \mathrm{ml}$

Glutaraldehyde $\quad 200 \mu \mathrm{l}$ 
Staining solution

PBS

$8 \mathrm{ml}$

Potassium ferrocyanide

$1 \mathrm{ml}$

Potassium ferricyanide

$1 \mathrm{ml}$

X-Gal

$200 \mu \mathrm{l}$

\subsection{Single cell shortening measurements by video-edge detection}

Single cell shortening of Ad-infected cardiomyocytes was measured 48 hours post transfection by a video-edge detection system (Crescent Electronics) using a custommade setup (Fig. 6).

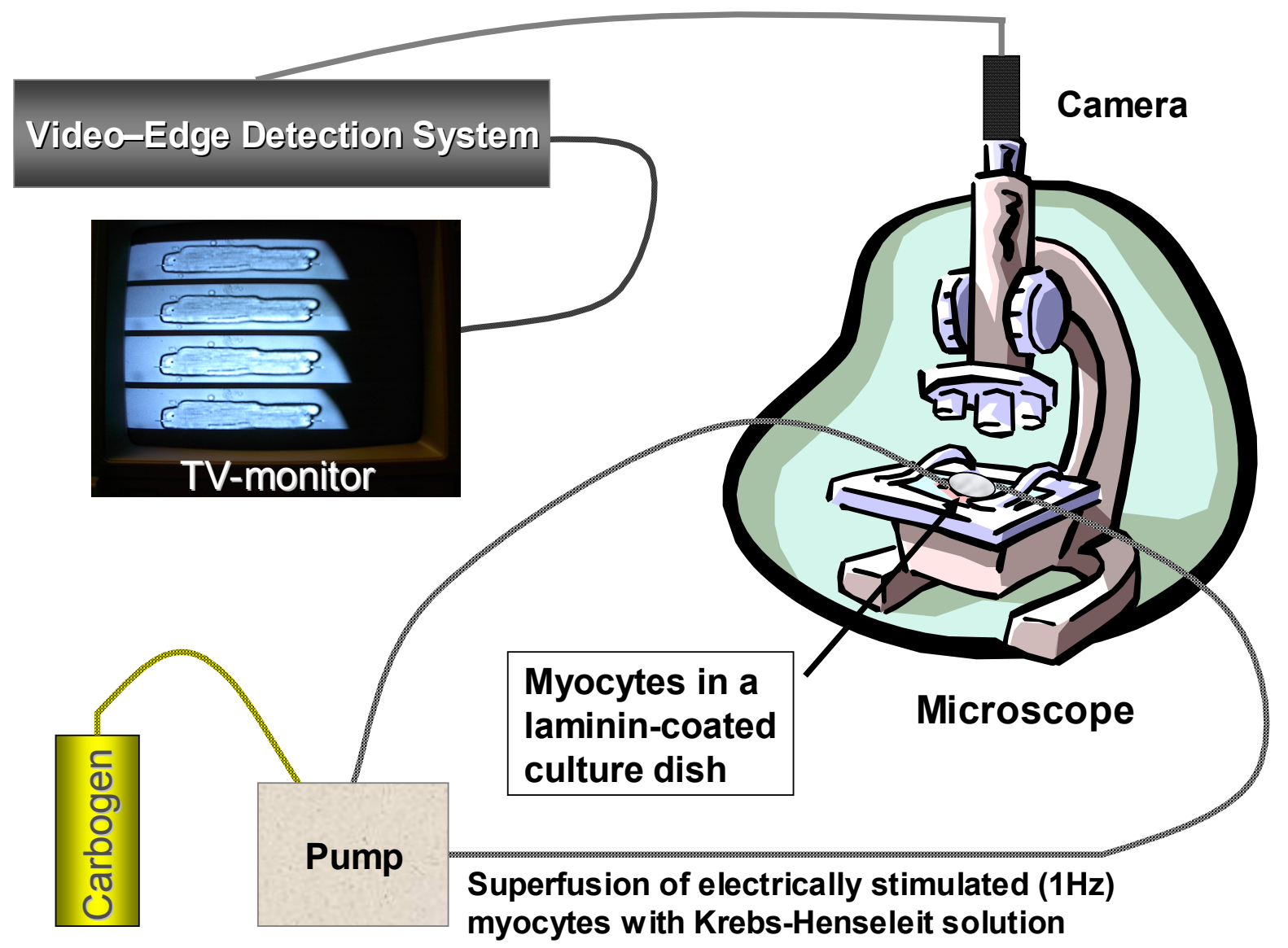

Figure 6. Setup for video-edge detection. For explanations see the text.

For measurements, cardiomyocytes plated on laminin-coated culture dishes were placed in a custom-made temperature-controlled chamber on a stage of a Nikon inverted microscope. The cells were superfused at $37^{\circ} \mathrm{C}$ at a flow rate of $2.5-3 \mathrm{ml} / \mathrm{min}$ with Krebs-Henseleit buffer solution equilibrated with carbogen gas $\left(95 \% \mathrm{O}_{2} / 5 \% \mathrm{CO}_{2}\right)$ 
and electrically stimulated at $1 \mathrm{~Hz}$ by means of platinum electrodes. The image of the myocytes was recorded using a Philips CCD camera and displayed on a TV monitor. Measured single cell shortening is expressed in percentage of diastolic cell length. Only cardiomyocytes that had maintained rod-shaped morphology, had intact cross striation, were attached to laminin on culture dish, and had clear sharp edges were examined by a video-edge detection system. A minimum of 8 cycles for each cardiomyocyte was recorded. On average, 15 cells per group in one set of experiments were examined for percentage of cell shortening (fractional shortening, FS). On- and off-line analysis was performed with custom designed Labview software (National Instruments).

10X Krebs-Henseleit stock

$\begin{array}{lll} & \text { For } 1 \mathrm{I} & \text { Final concentration } \\ \mathrm{NaCl} & 67.80 \mathrm{~g} & 116.1 \mathrm{mM} \\ \mathrm{KCl} & 3.73 \mathrm{~g} & 5 \mathrm{mM} \\ \mathrm{MgCl}_{2} \times 6 \mathrm{H}_{2} \mathrm{O} & 2.44 \mathrm{~g} & 1.2 \mathrm{mM} \\ \mathrm{Na}_{2} \mathrm{SO}_{4} & 1.7 \mathrm{~g} & 1.2 \mathrm{mM} \\ \mathrm{NaH}_{2} \mathrm{PO}_{4} \times \mathrm{H}_{2} \mathrm{O} & 2.76 \mathrm{~g} & 2 \mathrm{mM} \\ \mathrm{ddH}_{2} \mathrm{O} & \text { to } 1 \mathrm{I} & \end{array}$

1X Krebs-Henseleit solution with additives (prepared freshly)

For 11

10X stock

Glucose

$\mathrm{NaHCO}_{3}$

$1 \mathrm{M} \mathrm{CaCl}_{2}$ (Sigma)

$\mathrm{ddH}_{2} \mathrm{O}$
$100 \mathrm{ml}$

$1.8 \mathrm{~g}$

$1.7 \mathrm{~g}$

$1.75 \mu \mathrm{l}$

to $1 \mathrm{I}$
Final concentration

$1 \mathrm{X}$

$10 \mathrm{mM}$

$20 \mathrm{mM}$

$1.75 \mathrm{mM}$

\subsection{Protein chemistry and immunochemistry methods}

\subsubsection{Total protein homogenate preparation}

Protein lysate preparation from rabbit ventricular cardiomyocytes

All steps were performed at $4^{\circ} \mathrm{C}$ to prevent proteolytic degradation of the proteins. The cells, harvested and pelleted as described (3.1.3), were homogenized in $400 \mu \mathrm{l}$ of lysis buffer first by pipetting and then by freezing-thawing in liquid nitrogen. For better 
solubilization of the proteins, the samples were kept on ice for 20 minutes with occasional vortexing. Obtained primary lysates were passed 5 times through a $23 \mathrm{G}$ injection canula connected to a syringe and finally sonicated 3 times with 10 bursts on each occasion using a Sonopuls homogenizer HD2070 set at $25 \%$ of power. To pellet the nuclei and particular matter, crude homogenates were centrifuged for 5 minutes at $10000 \mathrm{~g}\left(4^{\circ} \mathrm{C}\right)$. The protein concentration of supernatants was determined by the BCA method using the kit from Pierce (Pierce Chemical Co). Aliquots of the prepared lysates were denatured in sample buffer containing $2 \% \beta$-mercaptoethanol by boiling at $95^{\circ} \mathrm{C}$ for 5 minutes and 20-60 $\mathrm{\mu g}$ of total protein was subjected to SDS-polyacrylamide gel electrophoresis (SDS-PAGE). The remaining lysates were frozen and kept at $-80^{\circ} \mathrm{C}$ until use.

\section{Lysis buffer}

$\begin{array}{lll} & \text { For } 250 \mathrm{ml} & \text { Final concentration } \\ 2 \mathrm{M} \text { Tris-HCl, pH 7.4 } & 2.5 \mathrm{ml} & 20 \mathrm{mM} \\ 100 \mathrm{mM} \text { EDTA } & 7.5 \mathrm{ml} & 3 \mathrm{mM} \\ 100 \mathrm{mM} \mathrm{EGTA} & 1.25 \mathrm{ml} & 0.5 \mathrm{mM} \\ 4 \mathrm{M} \mathrm{NaCl} & 16.625 \mathrm{ml} & 250 \mathrm{mM} \\ 500 \mathrm{mM} \beta \text {-glycerophosphate } & 10 \mathrm{ml} & 20 \mathrm{mM} \\ \mathrm{NP}-40 & 2.5 \mathrm{ml} & 1 \% \\ \mathrm{ddH}_{2} \mathrm{O} & \text { to } 250 \mathrm{ml} & \end{array}$

Prior to use the following protease inhibitors were added:

\begin{tabular}{lll} 
& For $10 \mathrm{ml}$ & Final concentration \\
$100 \mathrm{mM}$ pefabloc SC & $20 \mu \mathrm{l}$ & $0.2 \mathrm{mM}$ \\
$1 \mathrm{mM}$ aprotinin & $1 \mu \mathrm{l}$ & $100 \mathrm{nM}$ \\
$10 \mathrm{mM}$ leupeptin & $1 \mu \mathrm{l}$ & $1 \mu \mathrm{M}$ \\
$1.4 \mathrm{mM}$ pepstatin A & $7 \mu \mathrm{l}$ & $1 \mu \mathrm{M}$ \\
$1 \mathrm{M}$ benzamidine & $10 \mu \mathrm{l}$ & $1 \mathrm{mM}$ \\
$12.5 \mathrm{mM}$ calpain inhibitor I & $0.8 \mu \mathrm{l}$ & $1 \mu \mathrm{M}$ \\
$12.5 \mathrm{mM}$ calpain inhibitor II & $0.8 \mu \mathrm{l}$ & $1 \mu \mathrm{M}$ \\
& & \\
$5 X$ sample buffer & & Final concentration \\
\hline & & $250 \mathrm{mM}$
\end{tabular}


Glycerol $\quad 10 \mathrm{ml} \quad 50 \%$

The components were dissolved in $\mathrm{ddH}_{2} \mathrm{O}$ (up to $18 \mathrm{ml}$ ), $\mathrm{pH}$ was adjusted with $\mathrm{HCl}$ to 6.8 and finally the following components were added:

For $20 \mathrm{ml}$

Bromphenol Blue

$\beta$-Mercaptoethanol
$5 \mathrm{mg}$

$2 \mathrm{ml}$
Final concentration

$250 \mu \mathrm{g} / \mathrm{ml}$

$10 \%$

The solution was aliquoted and stored at $-20^{\circ} \mathrm{C}$. Protein samples were mixed with sample buffer in the proportion of $4: 1$, respectively.

\section{Protease inhibitors stocks}

$\begin{array}{lll} & & \text { Stock concentration } \\ \text { Pefabloc SC } & 48 \mathrm{mg} / 2 \mathrm{ml} \mathrm{H} \mathrm{O}_{2} & 100 \mathrm{mM} \\ \text { Aprotinin } & 3.3 \mathrm{mg} / 0.5 \mathrm{ml} \mathrm{H} \mathrm{O}_{2} & 1 \mathrm{mM} \\ \text { Leupeptin } & 2.5 \mathrm{mg} / 0.5 \mathrm{ml} \mathrm{H} \mathrm{O}^{\mathrm{O}} & 10 \mathrm{mM} \\ \text { Pepstatin A } & 2 \mathrm{mg} / 2 \mathrm{ml} \text { methanol } & 1.4 \mathrm{mM} \\ \text { Benzamidine } & 350 \mathrm{mg} / 2 \mathrm{ml} \mathrm{H} \mathrm{O}_{2} \mathrm{O} & 1 \mathrm{M} \\ \text { Calpain inhibitor I } & 2.5 \mathrm{mg} / 0.5 \mathrm{ml} \text { ethanol } & 12.5 \mathrm{mM} \\ \text { Calpain inhibitor II } & 2.5 \mathrm{mg} / 0.5 \mathrm{ml} \text { ethanol } & 12.5 \mathrm{mM}\end{array}$

Protease inhibitors stocks were dispenced into small aliquots and stored at $-20^{\circ} \mathrm{C}$.

\section{Product information}

Aprotinin: inhibits serine proteases such as kallikrein, trypsin, trypsinogen, chymotrypsin, plasmin, bacterial fibrinolysin.

Benzamidine: inhibits reversibly trypsin-like enzymes and serine proteases. Furthermore, it is a strong competitive inhibitor of trypsin, thrombin and plasmin. Benzamidine is sensitive to oxidation and for the most part interchangeable with pepstatin A.

Leupeptin: inhibits serine and thiol proteases such as trypsin, plasmin, proteinase K, kallikrein, papain, thrombin and cathepsin A and B. Not affected by leupeptin are $\alpha-, \beta-$, $\mathrm{Y}$ - and $\delta$-chymotrypsin, pepsin, cathepsin $\mathrm{D}$, elastase, rennin and thermolysin.

Pefabloc: irreversibly inhibits a broad range of serine proteases such as trypsin, chymotrypsin, thrombin and plasma kallikrein. Stability is affected both by $\mathrm{pH}$ and temperature. At alkaline $\mathrm{pH}$ a half-life is reduced. 
Pepstatin A: inhibits aspartate proteases such as pepsin, rennin, cathepsin D, bovine chemosin and many microbial acid proteases. It does not inhibit thiol proteases, neutral proteases or serine proteases.

\subsubsection{Preparation of CHAPS-solubilized cardiac membrane fraction (CSMF)}

Heart ventricles of two rabbits $(8 \mathrm{~g})$ were immersed in homogenization buffer,

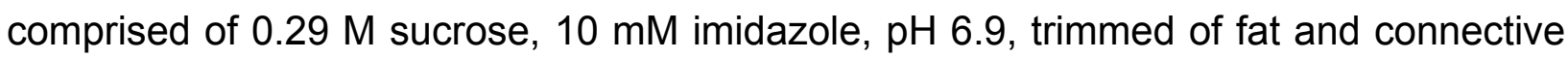
tissue and minced with scissors to pieces as small as possible. Minced tissue was homogenized in 7 volumes of homogenization buffer using sequentially a PotterElvehjem grinder with loosely and tightly fitted Teflon pestle. The Teflon pestle was driven mechanically at approximately $800 \mathrm{rpm}$ and 3-5 passes with a pestle of bigger clearance were followed by 7-10 passes with a pestle of smaller clearance. The homogenate was filtered through 4 layers of cloth and centrifuged at $4^{\circ} \mathrm{C}$ for 15 minutes at $7500 \mathrm{~g}_{\max }$ using a Sorvall ${ }^{\otimes} \mathrm{SS} 34$ rotor. The supernatant was recentrifuged at $4^{\circ} \mathrm{C}$ for 30 minutes at $45000 \mathrm{~g}_{\max }$ using a Kontron TFT 75.13 rotor. The supernatant was removed by aspiration and the pellet was resuspended in a small volume (700 $\mu$ l) of buffer for resuspension containing $1 \mathrm{M} \mathrm{NaCl}, 0.15 \mathrm{mM} \mathrm{CaCl} 2,0.1 \mathrm{mM}$ EDTA, $25 \mathrm{mM}$ Tris, $\mathrm{pH} 7.4$.

The protein concentration of the obtained membrane preparation was determined by the BCA method and the procedure was immediately continued to solubilization. The cardiac membrane fraction $(700 \mu \mathrm{l}$ with a protein concentration of $7.3 \mathrm{mg} / \mathrm{ml}$ ) was suspended in $644 \mu \mathrm{l}$ of buffer for solubilization supplemented with protease inhibitors. Solubilization was initiated by adding $336 \mu \mathrm{l}$ of CHAPS-phosphatidylcholine mixture. The final protein concentration was about $3 \mathrm{mg} / \mathrm{ml}$, which is required for efficient solubilization; the final concentrations of phospholipids and CHAPS were $5 \mathrm{mg} / \mathrm{ml}$ and $2 \%$, respectively. Membrane proteins were solubilized for $2 \mathrm{~h}$ at $4^{\circ} \mathrm{C}$ using end-over-end rotation mode. Afterwards, the non-solubilized material was sedimented at $4^{\circ} \mathrm{C}$ for 30 minutes at $83000 \mathrm{~g}_{\max }$ in a Kontron TFT 75.13 rotor. The supernatant contained the CSMF with a protein concentration of typically $3 \mathrm{mg} / \mathrm{ml}$ as determined with BCA method. This was used as a starting material for co-immunoprecipitation experiments.

\section{Buffer for homogenization}

500 mM imidazole, pH 6.9

For $60 \mathrm{ml}$

Final concentration

$2 \mathrm{M}$ sucrose

$1.2 \mathrm{ml}$

$10 \mathrm{mM}$

$8.7 \mathrm{ml}$

$0.29 \mathrm{M}$ 
$\mathrm{ddH}_{2} \mathrm{O}$

to $60 \mathrm{ml}$

$\mathrm{pH}$ of the buffer was controlled on the day of use and if necessary adjusted with $\mathrm{HCl}$ to 6.9 ; just prior to use the following protease inhibitors were added:

$\begin{array}{lll} & \text { For } 60 \mathrm{ml} & \text { Final concentration } \\ 100 \mathrm{mM} \text { pefabloc SC } & 120 \mu \mathrm{l} & 0.2 \mathrm{mM} \\ 1 \mathrm{mM} \text { aprotinin } & 6 \mu \mathrm{l} & 100 \mathrm{nM} \\ 10 \mathrm{mM} \text { leupeptin } & 6 \mu \mathrm{l} & 1 \mu \mathrm{M} \\ 1.4 \mathrm{mM} \text { pepstatin A } & 42 \mu \mathrm{l} & 1 \mu \mathrm{M} \\ 1 \mathrm{M} \text { benzamidine } & 60 \mu \mathrm{l} & 1 \mathrm{mM}\end{array}$

\section{Buffer for resuspension}

$\begin{array}{lll} & \text { For } 5 \mathrm{ml} & \text { Final concentration } \\ 500 \mathrm{mM} \text { Tris base, } \mathrm{pH} 7.4 & 250 \mu \mathrm{l} & 25 \mathrm{mM} \\ 2 \mathrm{M} \mathrm{NaCl} & 2.5 \mathrm{ml} & 1 \mathrm{M} \\ 1 \mathrm{M} \mathrm{CaCl}_{2} & 0.75 \mu \mathrm{l} & 0.15 \mathrm{mM} \\ 50 \mathrm{mM} \mathrm{EGTA}^{\mathrm{ddH}_{2} \mathrm{O}} & 10 \mu \mathrm{l} & 0.1 \mathrm{mM} \\ & \text { to } 5 \mathrm{ml} & \end{array}$

$\mathrm{pH}$ of the buffer was controlled on the day of use and if necessary adjusted with $\mathrm{HCl}$ to 7.4 ; just prior to use the following inhibitors were added:

$\begin{array}{lll} & \text { For } 5 \mathrm{ml} & \text { Final concentration } \\ 100 \mathrm{mM} \text { pefabloc SC } & 10 \mu \mathrm{l} & 0.2 \mathrm{mM} \\ 10 \mathrm{mM} \text { leupeptin } & 0.5 \mu \mathrm{l} & 1 \mu \mathrm{M}\end{array}$

Buffer for solubilization (prepared on the day of use)

Final concentration

$\begin{array}{lll}500 \mathrm{mM} \text { Tris base, } \mathrm{pH} 7.4 & 84 \mu \mathrm{l} & 65 \mathrm{mM} \\ 4 \mathrm{M} \mathrm{NaCl} & 420 \mu \mathrm{l} & 2.6 \mathrm{M} \\ 1 \mathrm{M} \mathrm{CaCl}_{2} & 0.25 \mu \mathrm{l} & 0.388 \mathrm{mM} \\ 50 \mathrm{mM} \mathrm{EGTA} & 3.36 \mu \mathrm{l} & 0.26 \mathrm{mM} \\ \mathrm{ddH}_{2} \mathrm{O} & \text { to } 644 \mu \mathrm{l} & \end{array}$

Prior to use the following inhibitors were added:
$100 \mathrm{mM}$ pefabloc SC
$3.36 \mu \mathrm{l}$
$0.522 \mathrm{mM}$
$10 \mathrm{mM}$ leupeptin
$0.17 \mu \mathrm{l}$
$2.6 \mu \mathrm{M}$ 
CHAPS stock

$\begin{array}{lll} & \text { For } 100 \mathrm{ml} & \text { Final concentration } \\ \text { CHAPS } & 10 \mathrm{~g} & 10 \% \\ \mathrm{ddH}_{2} \mathrm{O} & \text { to } 100 \mathrm{ml} & \end{array}$

The solution was stored at room temperature.

CHAPS-phosphatidylcholine mixture (prepared on the day of use)

Final concentration

$\begin{array}{lll}\text { Phosphatidylcholine } & 25 \mathrm{mg} & 25 \mathrm{mg} / \mathrm{ml} \\ 10 \% \text { CHAPS } & \text { to } 1 \mathrm{ml} & \end{array}$

Sonicate until clear.

\subsubsection{Isolation of ryanodine receptor from rabbit skeletal muscle and human heart}

Skeletal muscle and cardiac ryanodine receptors (RyR1 and RyR2, respectively) were obtained from rabbit skeletal muscle and human heart by sucrose density gradient centrifugation, which is based on a method described by Lai et al. (Lai et al., 1988; Lai et al., 1989). As depicted in Figure 7, this technique is a multi-step procedure, containing several differential and sucrose density gradient centrifugation steps, consisting of 2 major parts. In the first stage, heavy sarcoplasmic reticulum (HSR) membranes are isolated, since most RyRs are located here. In the second stage, RyR is solubilized from HSR and RyR-enriched fractions are prepared.

Isolation of heavy SR membranes from rabbit skeletal muscle/human heart

A female rabbit was sacrificed by intravenous injection of thiopental. Red and white muscles from hind legs and back were dissected from large blood vessels, nerves and fascia, frozen in liquid nitrogen and stored at $-80^{\circ} \mathrm{C}$ for several weeks until use. For experiments with human tissue, free from extensive fibrosis left ventricle of an explanted heart from a patient with idiopathic dilated cardiomyopathy (IDCMP), undergoing cardiac transplantation, was trimmed of fat, connective tissue and vessels and sliced into $10 \mathrm{~mm}$ cubes. The trimming was performed on a glass tray seatting on crushed ice. Afterwards, trimmed tissue was frozen in liquid nitrogen and stored at $-80^{\circ} \mathrm{C}$ for several months until use.

All subsequent operations of the procedure were performed at $4^{\circ} \mathrm{C}$. All centrifugation times indicated in the protocol included acceleration but not deceleration times. 


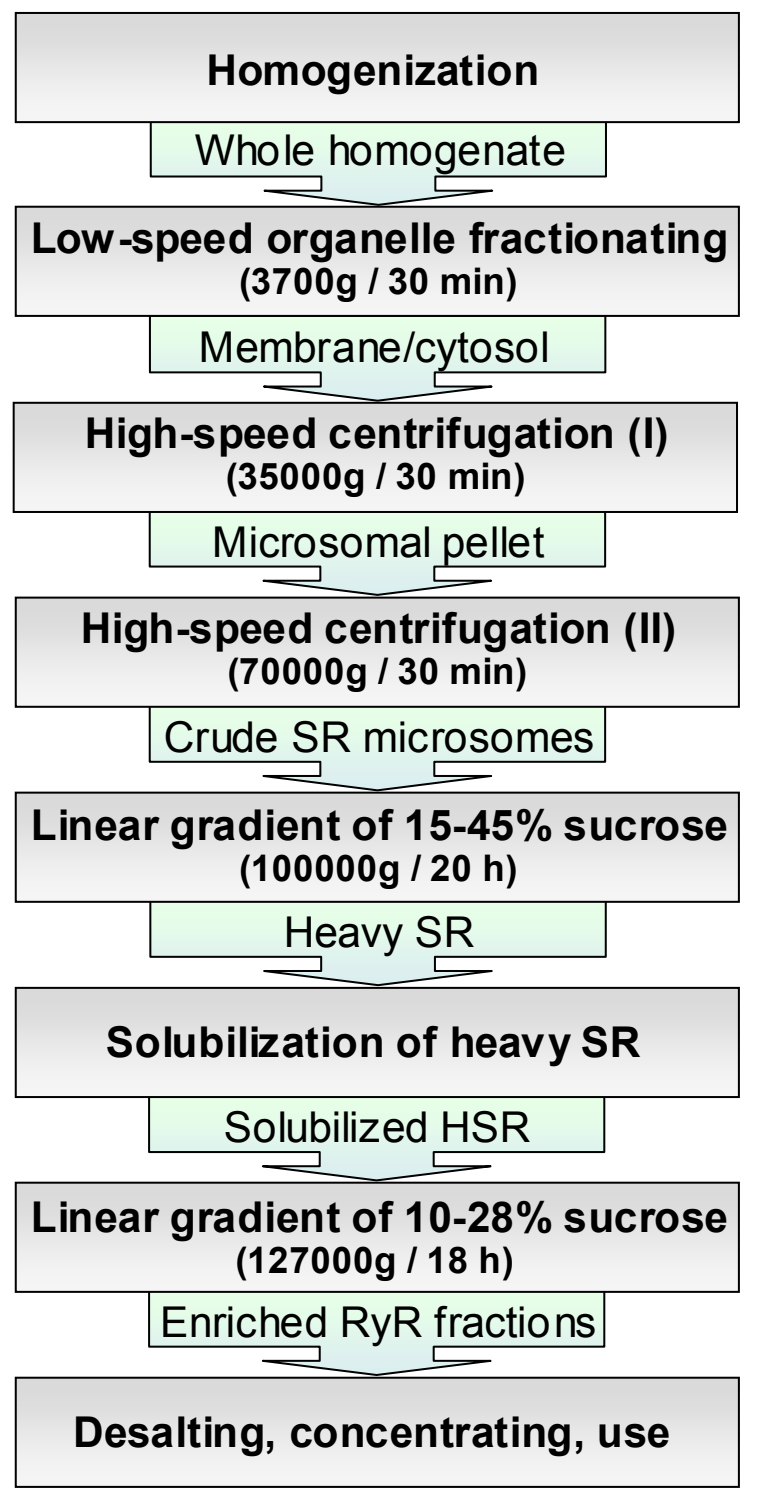

Figure 7. Scheme of isolation of RyR channel. For explanations see the text.

$100 \mathrm{~g}$ of rabbit skeletal muscle or human cardiac tissue were homogenized in $700 \mathrm{ml}$ of buffer 1, comprised of $0.1 \mathrm{M} \mathrm{NaCl}, 0.5 \mathrm{mM}$ EGTA, $10 \mathrm{mM} \mathrm{Na-HEPES,} \mathrm{pH} \mathrm{7.5,} \mathrm{using} \mathrm{a}$ Waring blender homogenizer at maximum speed 4 times for 25 seconds each time. The homogenate was centrifuged in centrifuge bottles (Sorvall ${ }^{\circledR}$ ) for 30 minutes at $3700 \mathrm{~g}_{\max }$ in a Sorvall ${ }^{\circledR}$ SA1500 rotor. The supernatant was filtered through the synthetic cotton. The filtrate $(450 \mathrm{ml})$ was devided between 6 polycarbonate screw lid tubes (Centricon ${ }^{\circledR}$ ) and centrifuged for 30 minutes at $35000 \mathrm{~g}_{\max }$ in a Kontron TFT45.94 rotor. The supernatants from this centrifugation were removed by aspiration, the soft pink pellets were resuspended for salt washing in a small amount $(2 \mathrm{ml}$ per pellet) of buffer 2 , containing $0.6 \mathrm{M} \mathrm{KCl}, 0.25 \mathrm{M}$ sucrose, $100 \mu \mathrm{M}$ EGTA, $90 \mu \mathrm{M} \mathrm{CaCl}_{2}, 10 \mathrm{mM}$ K-PIPES, 
$\mathrm{pH}$ 7.0. All pellets were combined, the volume adjusted to $60 \mathrm{ml}$ with buffer 2 and material was homogenized by hand homogenization (6 strokes) in a Potter-Elvehjem tissue grinder with a tightly fitted Teflon pestle. Afterwards, the suspension was transferred into a glass beaker, adjusted to $250 \mathrm{ml}$ with buffer 2 and left on ice in the cold room for 90 minutes. After incubation on ice, the solution was centrifuged in 4 full screw lid tubes for 30 minutes at $70000 \mathrm{~g}_{\max }$ in a Kontron TFT45.94 rotor. Meanwhile, four $32-\mathrm{ml}$ linear gradients with respect to $15-45 \%$ (w/v) sucrose were prepared. The gradient solution included $0.1 \mathrm{M} \mathrm{NaCl}, 100 \mu \mathrm{M} \mathrm{EGTA}, 90 \mu \mathrm{M} \mathrm{CaCl}_{2}, 0.1 \mathrm{mM}$ pefabloc, $10 \mathrm{mM}$ K-PIPES, pH 6.9. After removal of the supernatant by aspiration, $2 \mathrm{ml}$ of buffer 3 , containing $0.1 \mathrm{M} \mathrm{NaCl}, 0.3 \mathrm{M}$ sucrose, $10 \mathrm{mM} \mathrm{K-PIPES}, \mathrm{pH}$ 6.8, was added to each pellet, referred to as crude SR. All pellets were combined, adjusted to $16 \mathrm{ml}$ and homogenized by hand homogenization ( 3 strokes) in a Potter-Elvehjem tissue grinder with a tightly fitted Teflon pestle. $4 \mathrm{ml}$ of this suspension were layered over the prepared $32-\mathrm{ml}$ sucrose gradient. The gradients (4 per isolation) were centrifuged for $20 \mathrm{~h}$ at $100000 \mathrm{~g}_{\max }$ in a Beckman SW 27 rotor. $1 \mathrm{ml}$-size fractions were collected from the bottom using a custom-made apparatus connected to a peristaltic pump P-1 (Pharmacia Fine Chemicals) and fractions collector FRAC-100 (Pharmacia Fine Chemicals); the rate of fraction collection was $1 \mathrm{ml} / \mathrm{min} .5 \mu \mathrm{l}$ aliquots from every other fraction were subjected to SDS-PAGE on $7.5 \%$ gels prior to silver staining. Heavy SR fractions containing the peak amount of RyR (9 ml per $36 \mathrm{ml}$ gradient) were pooled, diluted with 2 volumes of buffer 3 , containing $0.1 \mathrm{M} \mathrm{NaCl}, 0.3 \mathrm{M}$ sucrose, $10 \mathrm{mM}$ K-PIPES, pH 6.8, and sedimented for 1 hour at $100000 \mathrm{~g}_{\max }$ in a Kontron TFT45.94 rotor. The pellets were resuspended in buffer 3 (the volume should be small enough to produce a concentration higher than $10 \mathrm{mg} / \mathrm{ml}$ ). The protein concentration was estimated by the BCA method using kit from Pierce and the procedure was immediately continued to ryanodine receptor preparation.

Solutions used for isolation of heavy SR membranes from rabbit skeletal muscle/human heart

All solutions used for heavy SR and RyR preparation were prepared in double distilled water; the $\mathrm{pH}$ values of solutions used in the isolation procedure are presented as the values at $25^{\circ} \mathrm{C}$ prior to cooling; protease inhibitors were added freshly just prior to use. 


\section{Buffer 1}

$\begin{array}{lll} & \text { For 1 I } & \text { Final concentration } \\ 5 \mathrm{M} \mathrm{NaCl} & 20 \mathrm{ml} & 0.1 \mathrm{M} \\ 100 \mathrm{mM} \mathrm{EGTA} & 5 \mathrm{ml} & 0.5 \mathrm{mM} \\ 500 \mathrm{mM} \text { Na-HEPES, pH } 7.5 & 20 \mathrm{ml} & 10 \mathrm{mM} \\ \mathrm{ddH}_{2} \mathrm{O} & \text { to } 1 \mathrm{I} & \end{array}$

$\mathrm{pH}$ of the buffer was controlled on the day of use and if necessary adjusted with $\mathrm{HCl}$ to 7.5; just prior to use the following inhibitors were added:

$\begin{array}{lll} & \text { For } 1 \mathrm{l} & \text { Final concentration } \\ 100 \mathrm{mM} \text { pefabloc SC } & 2 \mathrm{ml} & 0.2 \mathrm{mM} \\ 1 \mathrm{mM} \text { aprotinin } & 100 \mu \mathrm{l} & 100 \mathrm{nM} \\ 10 \mathrm{mM} \text { leupeptin } & 100 \mu \mathrm{l} & 1 \mu \mathrm{M} \\ 1.4 \mathrm{mM} \text { pepstatin A } & 700 \mu \mathrm{l} & 1 \mu \mathrm{M} \\ 1 \mathrm{M} \text { benzamidine } & 1 \mathrm{ml} & 1 \mathrm{mM} \\ 12.5 \mathrm{mM} \text { calpain inhibitor I } & 80 \mu \mathrm{l} & 1 \mu \mathrm{M} \\ 12.5 \mathrm{mM} \text { calpain inhibitor II } & 80 \mu \mathrm{l} & 1 \mu \mathrm{M}\end{array}$

\section{Buffer 2}

$\begin{array}{lll} & \text { For } 350 \mathrm{ml} & \text { Final concentration } \\ 2 \mathrm{M} \mathrm{KCl} & 105.11 \mathrm{ml} & 0.6 \mathrm{M} \\ \text { Sucrose } & 30 \mathrm{~g} & 0.25 \mathrm{M} \\ 100 \mathrm{mM} \mathrm{EGTA} & 350 \mu \mathrm{l} & 100 \mu \mathrm{M} \\ 1 \mathrm{M} \mathrm{CaCl}_{2} & 31.5 \mu \mathrm{l} & 90 \mu \mathrm{M} \\ 500 \mathrm{mM} \mathrm{K}_{2} \text {-PIPES, pH } 7.0 & 7 \mathrm{ml} & 10 \mathrm{mM} \\ \mathrm{ddH}_{2} \mathrm{O} & \text { to } 350 \mathrm{ml} & \end{array}$

$\mathrm{pH}$ of the buffer was controlled on the day of use and if necessary adjusted with $\mathrm{HCl}$ to 7.0; just prior to use the following inhibitors were added:

$\begin{array}{lll} & \text { For } 350 \mathrm{ml} & \text { Final concentration } \\ 100 \mathrm{mM} \text { pefabloc SC } & 700 \mu \mathrm{l} & 0.2 \mathrm{mM} \\ 1 \mathrm{mM} \text { aprotinin } & 35 \mu \mathrm{l} & 100 \mathrm{nM} \\ 10 \mathrm{mM} \text { leupeptin } & 35 \mu \mathrm{l} & 1 \mu \mathrm{M} \\ 1.4 \mathrm{mM} \text { pepstatin A } & 24.5 \mu \mathrm{l} & 1 \mu \mathrm{M} \\ 1 \mathrm{M} \text { benzamidine } & 350 \mu \mathrm{l} & 1 \mathrm{mM} \\ 12.5 \mathrm{mM} \text { calpain inhibitor I } & 28 \mu \mathrm{l} & 1 \mu \mathrm{M} \\ 12.5 \mathrm{mM} \text { calpain inhibitor II } & 28 \mu \mathrm{l} & 1 \mu \mathrm{M}\end{array}$


Buffer 3

$\begin{array}{lll} & \text { For } 25 \mathrm{ml} & \text { Final concentration } \\ 5 \mathrm{M} \mathrm{NaCl} & 500 \mu \mathrm{l} & 0.1 \mathrm{M} \mathrm{NaCl} \\ \text { Sucrose } & 2.57 \mathrm{~g} & 0.3 \mathrm{M} \\ 500 \mathrm{mM} \mathrm{K} \text {-PIPES, pH 6.8 } & 500 \mu \mathrm{l} & 10 \mathrm{mM} \\ \mathrm{ddH}_{2} \mathrm{O} & \text { to } 25 \mathrm{ml} & \\ \mathrm{pH} \text { of the buffer was controlled on the day of use and if necessary adjusted with } \mathrm{HCl} \text { to } \\ \text { 6.9; just prior to use } 0.1 \mathrm{mM} \text { pefabloc } \mathrm{SC} \text { was added. }\end{array}$

\section{Buffer 4}

$\begin{array}{lll} & \text { For } 200 \mathrm{ml} & \text { Final concentration } \\ 5 \mathrm{M} \mathrm{NaCl} & 4 \mathrm{ml} & 0.1 \mathrm{M} \\ 500 \mathrm{mM} \mathrm{K} \text {-PIPES, pH } 6.9 & 4 \mathrm{ml} & 10 \mathrm{mM} \\ 100 \mathrm{mM} \mathrm{EGTA}^{\mathrm{M} \mathrm{M} \mathrm{CaCl}_{2}} & 200 \mu \mathrm{l} & 100 \mu \mathrm{M} \\ \mathrm{ddH}_{2} \mathrm{O} & 18 \mu \mathrm{l} & 90 \mu \mathrm{M} \\ \mathrm{pH} \text { of the buffer was controlled on the day of use and if necessary adjusted with } \mathrm{HCl} \text { to } \\ \text { 6.9; just prior to use } 0.1 \mathrm{mM} \text { pefabloc } \mathrm{SC} \text { was added. }\end{array}$

\section{$\underline{\text { Sucrose gradient }}$}

$15 \%(w / v)$ sucrose

$\begin{array}{lll} & \text { For } 100 \mathrm{ml} & \text { Final concentration } \\ \text { Sucrose } & 15 \mathrm{~g} & 15 \% \\ \text { Buffer } 4 & \text { to } 100 \mathrm{ml} & \end{array}$

$45 \%(w / v)$ sucrose

$\begin{array}{lll} & \text { For } 100 \mathrm{ml} & \text { Final concentration } \\ \text { Sucrose } & 45 \mathrm{~g} & 45 \% \\ \text { Buffer } 4 & \text { to } 100 \mathrm{ml} & \end{array}$

Solubilization of ryanodine receptor and preparation of RyR-enriched fractions

It was found that among detergents used for solubilization of RyR channels, 3-[(3cholamidopropyl)dimethylammonio]-1-propane sulphonate (CHAPS) provides maximal solubilization of RyR in combination with maximal retention of ryanodine binding activity (Lai et al., 1989; Lindsay and Williams, 1991). Therefore, CHAPS was selected as a 
detergent for solubilization of the RyR. Phospholipids are essential to maintain the function of the ryanodine receptor in the solubilized state. In this stage, it is crucial to minimize the time of preparation to the solubilization procedure. Therefore all solutions used need to be prepared in advance but on the day of use.

Heavy SR membrane vesicles were suspended in $8 \mathrm{ml}$ of the solubilization solution (for the composition see over). The final protein concentration in the solubilization mixture should be $3 \mathrm{mg} / \mathrm{ml}$. The volume of added microsomes should not exceed $4 \mathrm{ml}$. After vigorous vortexing for 5 seconds, the solubilization mixture was kept on ice for 1 hour followed by 30 minutes at room temperature. Meanwhile, $9.5 \mathrm{ml}$ gradients of $10-28 \%$ sucrose were prepared. At the end of this period, unsolubilized material was sedimented for 30 minutes at $83000 \mathrm{~g}_{\max }$ in a Beckman Ti90 rotor. To separate RyR from other solubilized membrane components, $1.5 \mathrm{ml}$ of solubilized material was placed at the top of each of six $10-28 \%(\mathrm{w} / \mathrm{v})$ linear sucrose gradients (for the composition see over). The gradients were sedimented for 18 hours at $127000 \mathrm{~g}_{\max }$ in an SW41Ti Beckman rotor. $1 \mathrm{ml}$-size fractions were collected by upward displacement using a custom-made apparatus designed to introduce $65 \%$ sucrose to the bottom of the centrifuge tube to lift the gradient upwards into a collection device, which allows the gradient to be harvested from the top.

To identify RyR-containing fractions in the gradient, $10 \mu \mathrm{l}$ aliquots from each fraction were subjected to SDS-PAGE on $7.5 \%$ gels prior to silver staining. RyR-enriched fractions were localized at the same position (21-23\% sucrose) in all gradients and comprised $2 \mathrm{ml}$ per 11-ml gradient. RyR-enriched fractions were combined, dialyzed overnight using Spectra/Por ${ }^{\circledR}$ Cellulose Ester dialysis bag (Spectrum, MWCO 100000 Da) against 5000 volumes of buffer containing $10 \mathrm{mM} \mathrm{HEPES}, \mathrm{pH} 7.4$ and $150 \mathrm{mM}$ $\mathrm{NaCl}$. The concentration of RyR was determined by densitometry of the high molecular weight band with an apparent molecular weight of $563000 \mathrm{Da}$ (ryanodine receptor protomer) versus bovine serum albumin; it comprised $70 \mu \mathrm{g} / \mathrm{ml}$ for rabbit skeletal muscle RyR and $40 \mu \mathrm{g} / \mathrm{ml}$ for human cardiac RyR. If necessary, material was concentrated by ultrafiltration using a Vivaspin 20 concentrator with MWCO $100000 \mathrm{Da}$ (Sartorius/Göttingen). On each occasion material was aliquoted, frozen in liquid nitrogen and stored at $-80^{\circ} \mathrm{C}$. 
$\underline{\text { Solutions used }}$

\section{Buffer stock without AMP}

\begin{tabular}{lll}
\hline & For $500 \mathrm{ml}$ & Final concentration \\
$4 \mathrm{M} \mathrm{NaCl}$ & $250 \mathrm{ml}$ & $2 \mathrm{M}$ \\
$100 \mathrm{mM} \mathrm{EGTA}$ & $1 \mathrm{ml}$ & $200 \mu \mathrm{M}$ \\
$1 \mathrm{M} \mathrm{CaCl}_{2}$ & $150 \mu \mathrm{l}$ & $300 \mu \mathrm{M}$ \\
$500 \mathrm{mM} \mathrm{Na}^{-P I P E S}, \mathrm{pH} 7.3$ & $40 \mathrm{ml}$ & $40 \mathrm{mM}$ \\
$\mathrm{ddH}_{2} \mathrm{O}$ & to $500 \mathrm{ml}$ &
\end{tabular}

$\mathrm{pH}$ of the stock solution was controlled and if necessary adjusted with $\mathrm{HCl}$ to7.3; stock solution was stored at $4^{\circ} \mathrm{C}$.

$\underline{250 \mathrm{mM} \text { AMP }}$

$\begin{array}{lll} & \text { For } 10 \mathrm{ml} & \text { Final concentration } \\ \mathrm{Na}-\mathrm{AMP} & 0.868 \mathrm{~g} & 250 \mathrm{mM} \\ \mathrm{ddH}_{2} \mathrm{O} & \text { to } 10 \mathrm{ml} & \end{array}$

$\mathrm{pH}$ was adjusted with $\mathrm{NaOH}$ to 7.3 and stock solution was stored at $4{ }^{\circ} \mathrm{C}$.

Lipid stock

\begin{tabular}{|c|c|c|}
\hline & For $10 \mathrm{ml}$ & Final concentration \\
\hline $5 \mathrm{M} \mathrm{NaCl}$ & $1.79 \mathrm{ml}$ & $0.9 \mathrm{M}$ \\
\hline 500 mM Na-PIPES, pH 7.0 & $400 \mu \mathrm{l}$ & $20 \mathrm{mM}$ \\
\hline 100 mM EGTA & $10 \mu \mathrm{l}$ & $100 \mu \mathrm{M}$ \\
\hline $\mathrm{ddH}_{2} \mathrm{O}$ & to $10 \mathrm{ml}$ & \\
\hline \multicolumn{3}{|c|}{$\begin{array}{l}\mathrm{pH} \text { of the stock solution was controlled and if necessary adjusted with } \mathrm{HCl} \text { to } 7.0 \text {; stock } \\
\text { solution was stored at } 4^{\circ} \mathrm{C} \text {. }\end{array}$} \\
\hline \multicolumn{3}{|l|}{ CHAPS stock } \\
\hline & For $100 \mathrm{ml}$ & Final concentration \\
\hline CHAPS & $10 \mathrm{~g}$ & $10 \%$ \\
\hline $\mathrm{ddH}_{2} \mathrm{O}$ & to $100 \mathrm{ml}$ & \\
\hline
\end{tabular}

The solution was stored at room temperature.

\section{DTT stock}

$\begin{array}{lll} & \text { For } 3 \mathrm{ml} & \text { Final concentration } \\ \text { DTT } & 46.3 \mathrm{mg} & 0.1 \mathrm{M} \\ \mathrm{ddH}_{2} \mathrm{O} & \text { to } 3 \mathrm{ml} & \end{array}$


Buffer stock with AMP (prepared on the day of use)

$\begin{array}{ll}\text { Buffer stock without AMP } & 48 \mathrm{ml} \\ 250 \mathrm{mM} \text { AMP } & 2 \mathrm{ml}\end{array}$

Phosphatidylcholine mixture (prepared on the day of use)

$\begin{array}{ll}\text { Phosphatidylcholine (Sigma) } & 1 \mathrm{~g} \\ \text { 10\% CHAPS } & 9 \mathrm{ml} \\ \text { Lipid stock } & 1 \mathrm{ml} \\ 100 \mathrm{mM} \text { pefabloc SC } & 10 \mu \mathrm{l} \\ 100 \mathrm{mM} \text { DTT } & 10 \mu \mathrm{l}\end{array}$

The mixture was cooled on ice and homogenized using glass homogenizer with tightly fitted glass pestle.

Solubilization solution (prepared on the day of use)

$\begin{array}{ll}\text { Buffer stock with AMP } & 6 \mathrm{ml} \\ 10 \% \text { CHAPS } & 1.28 \mathrm{ml} \\ \text { PC mixture } & 0.6 \mathrm{ml}\end{array}$

Prior to use, DTT and the following inhibitors were added:

$0.1 \mathrm{M}$ DTT

$0.1 \mathrm{M}$ pefabloc SC

$1 \mathrm{mM}$ aprotinin

$10 \mathrm{mM}$ leupeptin

$1.4 \mathrm{mM}$ pepstatin A

$12.5 \mathrm{mM}$ calpain inhibitor I

$12.5 \mathrm{mM}$ calpain inhibitor II
$120 \mu \mathrm{l}$

$12 \mu \mathrm{l}$

$2 \mu \mathrm{l}$

$2 \mu \mathrm{l}$

$8 \mu \mathrm{l}$

$12 \mu \mathrm{l}$

$12 \mu \mathrm{l}$

Solubilization mixture (for 6 gradients)

Solubilization solution

HSR

$\mathrm{ddd}_{2} \mathrm{O}$
$8 \mathrm{ml}$

$\leq 4 \mathrm{ml}$

to $12 \mathrm{ml}$ (if HSR is added in

volume less than $4 \mathrm{ml}$ ) 


\subsubsection{Co-immunoprecipitation}

\section{Preparation of cardiac homogenates}

Left ventricular tissue $(100 \mathrm{mg})$ from failing and sham-operated animals was thawed and homogenized in 1 volume $(100 \mu \mathrm{l})$ of buffer for homogenization comprised of $200 \mathrm{mM} \mathrm{NaCl}, 20 \mathrm{mM} \mathrm{NaF}, 1 \mathrm{mM} \mathrm{Na}_{3} \mathrm{VO}_{4}, 1 \mathrm{mM}$ DTT and $50 \mathrm{mM}$ Tris- $\mathrm{HCl}$, pH 7.4. A steel pestle tightly fitted to the Eppendorf tube containing the tissue was mechanically driven at approximately $800 \mathrm{rpm}$. The homogenates were centrifuged for 10 minutes at $3000 \mathrm{~g}\left(4^{\circ} \mathrm{C}\right)$. Supernatants were transferred to new tubes and pellets were reextracted 3 times in initial volume of buffer used for homogenization followed by centrifugation as described. Supernatants from all centrifugation steps were combined and protein concentration was determined by the BCA method using the kit from Pierce.

\section{Coupling antigen to antibody}

Cardiac homogenates (1 $\mathrm{mg}$ of protein in each sample) were suspended in dilution medium containing $0.9 \% \mathrm{NaCl}, 0.25 \%$ Triton $\mathrm{X}-100,1 \mathrm{mM} \mathrm{NaF}, 1 \mathrm{mM} \mathrm{Na}_{3} \mathrm{VO}_{4}$ and $50 \mathrm{mM}$ Tris- $\mathrm{HCl}, \mathrm{pH} 7.4$ to bring the volume of each sample up to $500 \mu \mathrm{l}$. The samples were kept on ice for 20 minutes with occasional vortexing. CSMF, prepared as described in 3.4.2, was diluted in one volume of PBS to reduce the concentration of salt and detergent; one sample of CSMF contained $1 \mathrm{mg}$ of total protein in a final volume of $600 \mu \mathrm{l} .8 \mu \mathrm{g}$ of mouse monoclonal anti-ryanodine receptor (RyR) antibody (34C clone, $A B R$ ) was added to the samples containing cardiac homogenates. To the samples containing CSMF, $10 \mu \mathrm{g}$ of anti-RyR antibody (C3-33 clone, ABR) and $20 \mu \mathrm{g}$ of goat polyclonal anti-FKBP12 antibody (Santa Cruz) was added. Samples were incubated for $4 \mathrm{~h}$ at $4^{\circ} \mathrm{C}$ using an end-over-end rotator set at low speed. Mouse monoclonal antiSERCA2a antibody added to one sample at quantity of $4 \mu \mathrm{g}$ served as control antibody. One sample was incubated with protein G-sepharose beads only. Additionally, to verify the specificity of interaction, one sample was incubated with FK506 prior to addition of the antibody.

\section{Precipitation of immune complexes}

Protein G-sepharose Fast Flow was prepared as follows: per each $\mathrm{ml}$ of bed volume, $1.33 \mathrm{ml}$ of $75 \%$ slurry in $20 \%$ ethanol is needed; based on this ratio, a sufficient amount of $75 \%$ slurry was transferred to a $15 \mathrm{ml}$ tube and the matrix was sedimented by centrifugation at $500 \mathrm{~g}_{\max }$ for 5 minutes. The supernatant was carefully aspirated with a 
pipette. Next, protein G-sepharose was washed with 10 bed volumes of dilution medium per $1.33 \mathrm{ml}$ of the original slurry and sedimented as described above. The supernatant was discarded and for each $1.33 \mathrm{ml}$ of the original slurry of protein G-sepharose $1 \mathrm{ml}$ of dilution media was added. This procedure produced $50 \%$ slurry. $100 \mu \mathrm{l}$ of this slurry was added to each tube with formed antigen-antibody complexes. The mixture was gently mixed for 4 hours at $4^{\circ} \mathrm{C}$ using an end-over-end rotator set at low speed. After the end of the incubation time, the matrix was sedimented by centrifugation for 30 seconds at maximum speed of an Eppendorf benchtop MiniSpin centrifuge. The supernatants were discarded with a $29 \mathrm{G}$ canula connected to a syringe and the pellets were washed 3 times with $500 \mu \mathrm{l}$ of $50 \mathrm{mM}$ Tris- $\mathrm{HCl}, \mathrm{pH} 7.4$. The tubes were inverted carefully 5 times to mix. After each washing step, the immunoprecipitates were recovered by centrifugation as described.

\section{Dissociation and analysis}

The final pellets were suspended in $60 \mu \mathrm{l}$ of $2 \mathrm{X}$ sampler buffer, heated to $95^{\circ} \mathrm{C}$ for 5 minutes and centrifuged for 2 minutes at maximum speed. The supernatants were carefully transferred to a new Eppendorf tube and analyzed by immunoblotting.

Buffer for homogenization with protease inhibitors (prepared just prior to use)

$\begin{array}{lll} & \text { For } 5 \mathrm{ml} & \text { Final concentration } \\ 2 \mathrm{M} \mathrm{Tris}-\mathrm{HCl}, \mathrm{pH} 7.4 & 125 \mu \mathrm{l} & 50 \mathrm{mM} \\ 4 \mathrm{M} \mathrm{NaCl} & 250 \mu \mathrm{l} & 200 \mathrm{mM} \\ 200 \mathrm{mM} \mathrm{NaF} & 500 \mu \mathrm{l} & 20 \mathrm{mM} \\ 100 \mathrm{mM} \mathrm{Na}_{3} \mathrm{VO}_{4} & 50 \mu \mathrm{l} & 1 \mathrm{mM} \\ 100 \mathrm{mM} \mathrm{DTT} & 50 \mu \mathrm{l} & 1 \mathrm{mM} \\ 100 \mathrm{mM} \text { pefabloc SC } & 10 \mu \mathrm{l} & 0.2 \mathrm{mM} \\ 1 \mathrm{mM} \text { aprotinin } & 0.5 \mu \mathrm{l} & 100 \mathrm{nM} \\ 10 \mathrm{mM} \text { leupeptin } & 0.5 \mu \mathrm{l} & 1 \mu \mathrm{M} \\ 1.4 \mathrm{mM} \text { pepstatin A } & 3.5 \mu \mathrm{l} & 1 \mu \mathrm{M} \\ 1 \mathrm{M} \mathrm{benzamidine} & 5 \mu \mathrm{l} & 1 \mathrm{mM} \\ 12.5 \mathrm{mM} \text { calpain inhibitor I } & 0.4 \mu \mathrm{l} & 1 \mu \mathrm{M} \\ 12.5 \mathrm{mM} \text { calpain inhibitor Il } & 0.4 \mu \mathrm{l} & 1 \mu \mathrm{M} \\ \mathrm{ddH}_{2} \mathrm{O} & \text { to } 5 \mathrm{ml} & \end{array}$


Dilution medium (prepared just prior to use)

Final concentration

Modified RIPA buffer $\quad 5 \mathrm{ml}$

$200 \mathrm{mM} \mathrm{NaF} \quad 25 \mu \mathrm{l} \quad 1 \mathrm{mM}$

$100 \mathrm{mM} \mathrm{Na}_{3} \mathrm{VO}_{4} \quad 50 \mu \mathrm{l} \quad 1 \mathrm{mM}$

$100 \mathrm{mM}$ pefabloc SC $\quad 10 \mu \mathrm{l}$

$1 \mathrm{mM}$ aprotinin $\quad 0.5 \mu \mathrm{l} \quad 100 \mathrm{nM}$

$10 \mathrm{mM}$ leupeptin $\quad 0.5 \mu \mathrm{l} \quad 1 \mu \mathrm{M}$

$1.4 \mathrm{mM}$ pepstatin A $\quad 3.5 \mu \mathrm{l} \quad 1 \mu \mathrm{M}$

$1 \mathrm{M}$ benzamidine $\quad 5 \mu \mathrm{l} \quad 1 \mathrm{mM}$

$12.5 \mathrm{mM}$ calpain inhibitor I $\quad 0.4 \mu \mathrm{l} \quad 1 \mu \mathrm{M}$

$12.5 \mathrm{mM}$ calpain inhibitor II $\quad 0.4 \mu \mathrm{l} \quad 1 \mu \mathrm{M}$

Modified RIPA buffer

$\begin{array}{lll} & \text { For } 50 \mathrm{ml} & \text { Final concentration } \\ 2 \mathrm{M} \mathrm{Tris}-\mathrm{HCl}, \mathrm{pH} 7.4 & 1.25 \mathrm{ml} & 50 \mathrm{mM} \\ 4 \mathrm{M} \mathrm{NaCl} & 1.93 \mathrm{ml} & 154 \mathrm{mM} \\ \text { Triton X-100 } & 125 \mu \mathrm{ll} & 0.25 \% \\ \mathrm{ddH}_{2} \mathrm{O} & \text { to } 50 \mathrm{ml} & \end{array}$

$\underline{\text { XX sample buffer }}$

For $20 \mathrm{ml} \quad$ Final concentration

$\begin{array}{lll}\text { Tris- } \mathrm{HCl} & 0.79 \mathrm{~g} & 250 \mathrm{mM} \\ \text { SDS } & 2 \mathrm{~g} & 10 \% \\ \text { Glycerol } & 10 \mathrm{ml} & 50 \%\end{array}$

The components were dissolved in $\mathrm{ddH}_{2} \mathrm{O}$ (up to $18 \mathrm{ml}$ ), $\mathrm{pH}$ was adjusted with $\mathrm{HCl}$ to 6.8 and finally the following components were added:

$\begin{array}{lll} & \text { For } 20 \mathrm{ml} & \text { Final concentration } \\ \text { Bromphenol Blue } & 5 \mathrm{mg} & 250 \mu \mathrm{g} / \mathrm{ml} \\ \text { ß-Mercaptoethanol } & 2 \mathrm{ml} & 10 \%\end{array}$

Solution was aliquoted and stored at $-20^{\circ} \mathrm{C}$.

$\underline{2 X \text { sample buffer }}$

For $20 \mathrm{ml} \quad$ Final concentration

$\begin{array}{lll}\text { Tris- } \mathrm{HCl} & 0.32 \mathrm{~g} & 100 \mathrm{mM}\end{array}$ 


\section{SDS}

$$
0.8 \mathrm{~g}
$$

$4 \%$

Glycerol

$$
4 \mathrm{ml}
$$

$20 \%$

The components were dissolved in $\mathrm{ddH}_{2} \mathrm{O}$ (up to $19.2 \mathrm{ml}$ ), $\mathrm{pH}$ was adjusted with $\mathrm{HCl}$ to 6.8 and finally the following components were added:

$\begin{array}{lll} & \text { For } 20 \mathrm{ml} & \text { Final concentration } \\ \text { Bromphenol Blue } & 2 \mathrm{mg} & 100 \mu \mathrm{g} / \mathrm{ml} \\ \beta \text {-Mercaptoethanol } & 0.8 \mathrm{ml} & 4 \%\end{array}$

Solution was aliquoted and stored at $-20^{\circ} \mathrm{C}$.

\subsubsection{Immunoblotting}

Samples for loading were prepared by mixing of either protein lysates or other protein preparations, obtained as described in the previous chapters, with sample buffer and heating for 5 minutes at $95^{\circ} \mathrm{C}$.

\section{Casting of SDS-polyacrylamide gel}

For all applications described, a Tris/glycine SDS polyacrylamide gel (SDS-PAAG) system was used according to the method of Laemmli (Laemmli, 1970). For hand casting of the gels for vertical electrophoresis, a Mini-PROTEAN ${ }^{\mathrm{TM}}$ || Electrophoresis Cell (BioRad) was used. Solutions for the separating gels of the desired percentage and for the $4 \%$ stacking gel were prepared as described below. The casting of the gels was performed according to manufacturer's instructions. Precast $4-20 \%$ linear gradient Tris/glycine SDS-PAAGs (BioRad) compatible with this system were used alternatively.

\section{SDS-polyacrylamide gel electrophoresis (SDS-PAGE) and electrophoretic transfer}

The samples were loaded onto the bottom of the wells. Electrophoresis was run at a constant current of $25 \mathrm{~mA}$ per gel. Electrophoretic transfer was carried out essentially as described by Towbin (Towbin et al., 1979). Prior to stopping the gel running, fiber pads, filter paper and nitrocellulose transfer membrane $(0.45 \mu \mathrm{M}$ pore size) were soaked in transfer buffer. After electrophoresis, the gel was removed out of the plates and immersed in transfer buffer. For electrophoretic transfer of proteins from the gel to a membrane, a Mini-Trans-Blot ${ }^{\circledR}$ Cell (BioRad), compatible with the described system for electrophoresis, was utilized. The transblot sandwich was assembled according to the manufacturer's instructions from BioRad in the following order starting from the anode side: sponge, 2 sheets of filter paper, nitrocellulose membrane, gel, 2 sheets of filter paper, sponge. The assembled transblot sandwich was inserted into the transblot cell 
filled with transfer buffer. An ice-cooling unit was set behind the cathode side of transblot cell. For most of the proteins, the transfer ran for 2 hours at $500 \mathrm{~mA}$ with one change of the ice-cooling unit after the first hour. For high molecular weigh proteins (e.g., ryanodine receptor), the transfer was extended to 3 hours.

\section{Immunovisualization}

After transfer, the membrane was incubated on a rocking platform with blocking solution overnight at $4^{\circ} \mathrm{C}$ (or alternatively, for 60 minutes at room temperature). Next, the membrane was incubated with primary antibody diluted in antibody dilution buffer for 1 hour at room temperature. After washing (six times five minutes each), the membrane was incubated with HRP-conjugated secondary antibody diluted in antibody dilution buffer for 1 hour at room temperature. Afterwards the membrane was washed as before. For the chemiluminescent detection, SuperSignal ${ }^{\circledR}$ West Pico Chemiluminescent Substrate (Pierce) was used. Substrate working solution was prepared by mixing of equal volumes of two substrate components. The membrane was incubated with substrate working solution for 5 minutes at room temperature, laid between sheets of transparent plastic protector and exposed to X-ray film, which was developed afterwards according to manufacturer's instructions.

\section{Separating gel}

\begin{tabular}{|c|c|c|c|c|c|c|}
\hline \multirow{2}{*}{ Components } & \multicolumn{2}{|c|}{$10 \%$ gel } & \multicolumn{2}{c|}{$12.5 \%$ gel } & \multicolumn{2}{c|}{$15 \%$ gel } \\
\cline { 2 - 7 } & $10 \mathrm{ml}$ & $15 \mathrm{ml}$ & $10 \mathrm{ml}$ & $15 \mathrm{ml}$ & $10 \mathrm{ml}$ & $15 \mathrm{ml}$ \\
\hline $\begin{array}{c}\text { Rotiphorese } \\
\text { Gel } 30\end{array}$ & $3.33 \mathrm{ml}$ & $5 \mathrm{ml}$ & $4.17 \mathrm{ml}$ & $6.25 \mathrm{ml}$ & $5 \mathrm{ml}$ & $7.5 \mathrm{ml}$ \\
\hline $\begin{array}{c}4 \mathrm{X} \text { Tris/SDS } \\
\mathrm{pH} 8.8\end{array}$ & $2.5 \mathrm{ml}$ & $3.75 \mathrm{ml}$ & $2.5 \mathrm{ml}$ & $3.75 \mathrm{ml}$ & $2.5 \mathrm{ml}$ & $3.75 \mathrm{ml}$ \\
\hline $\begin{array}{c}\text { ddH }{ }_{2} \mathrm{O} \\
10 \% \text { APS }\end{array}$ & $4.16 \mathrm{ml}$ & $6.25 \mathrm{ml}$ & $3.33 \mathrm{ml}$ & $5 \mathrm{ml}$ & $2.5 \mathrm{ml}$ & $3.75 \mathrm{ml}$ \\
\hline TEMED & $7 \mu \mathrm{l}$ & $50 \mu \mathrm{l}$ & $33 \mu \mathrm{l}$ & $50 \mu \mathrm{l}$ & $33 \mu \mathrm{l}$ & $50 \mu \mathrm{l}$ \\
\hline
\end{tabular}


4\% stacking gel

Component

Rotiphorese Gel 30

4X Tris/SDS, pH 6.8

$\mathrm{ddH}_{2} \mathrm{O}$

$10 \%$ APS

TEMED

\section{X Tris/SDS, $\mathrm{pH} 6.8$}

For $100 \mathrm{ml}$

Tris base

$6.05 \mathrm{~g}$

SDS

$0.4 \mathrm{~g}$

dd $\mathrm{H}_{2} \mathrm{O}$ to $100 \mathrm{ml}$

Amount

$0.67 \mathrm{ml}$

$1.25 \mathrm{ml}$

$3.08 \mathrm{ml}$

$30 \mu \mathrm{l}$

$10 \mu \mathrm{l}$

$\mathrm{pH}$ was adjusted with $37 \% \mathrm{HCl}$ to 6.8 ; the solution was stored at room temperature.

\section{$\underline{4 \mathrm{X} \text { Tris/SDS, } \mathrm{pH} 8.8}$}

$\begin{array}{ll} & \text { For } 250 \mathrm{ml} \\ \text { Tris base } & 45.5 \mathrm{~g} \\ \mathrm{SDS} & 1 \mathrm{~g} \\ \mathrm{ddH}_{2} \mathrm{O} & \text { to } 250 \mathrm{ml} \\ \mathrm{pH} \text { was adjusted with } 37 \% \mathrm{HCl} \text { to } 6.8 \text {; the solution was stored at room temperature. }\end{array}$

$\underline{\text { 5X SDS-PAGE running buffer }}$

For 21

Tris base

$30.2 \mathrm{~g}$

SDS

$144 \mathrm{~g}$

$\mathrm{dd}_{2} \mathrm{O}$

to 21

$\mathrm{pH}$ was adjusted with $37 \% \mathrm{HCl}$ to 8.3 ; the solution was stored at room temperature.

1X SDS-PAGE running buffer

$\begin{array}{ll} & \text { For 2 I } \\ 5 \mathrm{X} \text { stock } & 400 \mathrm{ml} \\ \mathrm{ddH}_{2} \mathrm{O} & \text { to } 2 \mathrm{I}\end{array}$


$\underline{5 X}$ transfer buffer

\section{For 2 I}

Tris base

$39.4 \mathrm{~g}$

Glycine

$\mathrm{ddH}_{2} \mathrm{O}$ to 2 I

$\mathrm{pH}$ was adjusted with $37 \% \mathrm{HCl}$ to 8.3 ; the solution was stored at room temperature.

$1 \mathrm{X}$ SDS-PAGE transfer buffer

$\begin{array}{lll} & \text { For } 2 \mathrm{I} & \text { Final concentration } \\ 5 \mathrm{X} \text { stock } & 400 \mathrm{ml} & 1 \mathrm{X} \\ 100 \% \text { methanol } & 400 \mathrm{ml} & 20 \% \\ 10 \% \text { SDS } & 2 \mathrm{ml} & 0.01 \% \\ \mathrm{ddH}_{2} \mathrm{O} & \text { to } 2 \mathrm{I} & \end{array}$

10X washing buffer

For 2 I

Tris base

$48.4 \mathrm{~g}$

$\mathrm{NaCl}$

$58.48 \mathrm{~g}$

$\mathrm{ddH}_{2} \mathrm{O}$

to 21

$\mathrm{pH}$ was adjusted with $\mathrm{HCl}$ to 7.4 ; the solution was stored at room temperature.

$\underline{1 X \text { washing buffer }}$

$\begin{array}{lll} & \text { For } 5 \mathrm{I} & \text { Final concentration } \\ 10 X \text { stock } & 500 \mathrm{ml} & 1 \mathrm{X} \\ \text { Tween } 20 & 5 \mathrm{ml} & 0.1 \% \\ \mathrm{ddH}_{2} \mathrm{O} & \text { to } 5 \mathrm{I} & \end{array}$

Blocking reagent

$\begin{array}{lll} & \text { For } 50 \mathrm{ml} & \text { Final concentration } \\ \text { Nonfat dry milk } & 2.5 \mathrm{~g} & 5 \% \\ \text { 1X washing buffer } & \text { to } 50 \mathrm{ml} & \end{array}$

The solution should be prepared freshly and can be stored at $4^{\circ} \mathrm{C}$ for $1-2$ days.

Antibody incubation buffer

$\begin{array}{lll} & \text { For } 50 \mathrm{ml} & \text { Final concentration } \\ 5 \% \text { nonfat milk } & 5 \mathrm{ml} & 0.5 \% \\ 1 \mathrm{X} \text { washing buffer } & \text { to } 50 \mathrm{ml} & \end{array}$


Primary antibodies were used in the following dilutions:

Antibody

Anti-phospho-RyR Ab (RyR2-P2809)

Anti-RyR Ab (RyR2-5029)

Anti-RyR Ab (MA3-916)

Anti-RyR Ab (MA3-925)

Anti-FKBP12 Ab (C-19)

Anti-FKBP12 Ab (SA-169)

Anti-Calsequestrin Ab (PA1-913)

Anti-GST Ab
Used dilution

1:10000

$1: 10000$

$1: 500$

$1: 2500$

$1: 1000$

$1: 500$

$1: 5000$

$1: 100000$

Secondary HRP-conjugeted antibodies were used in the following dilutions:

Antibody

Sheep anti-mouse whole Ig

Donkey anti-rabbit whole lg

Rabbit anti-goat affinity-purified IgG

Donkey anti-mouse affinity-purified IgG
Used dilution

1:10000

$1: 10000$

$1: 20000$

$1: 500$

\subsubsection{Isolation of IgG using protein A-sepharose 4B}

To purify IgG (SA-169) from rabbit polyclonal anti-serum raised against peptide sequence of the FKBP12.6, affinity chromatography using protein A-sepharose was utilized.

Preparing the medium, packing protein A-sepharose and equilibration

Protein A-sepharose Fast Flow was prepared as follows: per each $\mathrm{ml}$ of bed volume $1.33 \mathrm{ml}$ of $75 \%$ slurry in $20 \%$ ethanol is needed; based on this ratio, $3.325 \mathrm{ml}$ of $75 \%$ slurry was transferred to $50 \mathrm{ml}$ tube and the matrix was sedimented by centrifugation at $500 \mathrm{~g}_{\max }$ for 5 minutes. The supernatant was carefully aspirated with a pipette. Next, protein A-sepharose was washed with 10 bed volumes of binding buffer, containing $0.15 \mathrm{M} \mathrm{NaCl}$ and $10 \mathrm{mM} \mathrm{NaH} \mathrm{PO}_{4} \times \mathrm{H}_{2} \mathrm{O}, \mathrm{pH} 7.4$, per $1.33 \mathrm{ml}$ of the original slurry, and sedimented as described above. The supernatant was discarded and for each $1.33 \mathrm{ml}$ of the original slurry of protein G-sepharose $1 \mathrm{ml}$ of dilution media was added. This procedure produced $50 \%$ slurry. The prepared $50 \%$ slurry was poured in one continuous motion into the disposable column with bottom and top porous discs (IBA, Gottingen); the column was subsequently equilibrated with 10 volumes of binding buffer. 
Binding IgG to protein A-sepharose Fast Flow

Rabbit immune serum $(2 \mathrm{ml}$ ) was centrifuged for 2 minutes at $12000 \mathrm{~g}$ to remove aggregates and diluted with one volume of binding buffer. The material was loaded on the column and ran driven by gravity. The flowthrough was collected and loaded onto the column repeatedly. When the entire volume of liquid had entered the gel, the column was closed with a bottom cap and kept at room temperature for 1 hour.

\section{Washing and elution}

The column was washed from nonspecifically bound material with 10 bed volumes of washing buffer, comprised of $0.15 \mathrm{mM} \mathrm{NaCl}$ and $0.1 \mathrm{M} \mathrm{NaH}_{2} \mathrm{PO}_{4} \mathrm{xH}_{2} \mathrm{O}, \mathrm{pH}$ 7.4. $2 \mathrm{ml}$ fractions were collected and protein concentration was controlled spectrophotometrically by calculating from the $O D_{280}$. IgG was eluted from the column with 5 bed volumes of elution buffer, containing $0.15 \mathrm{mM} \mathrm{NaCl}$ and $0.1 \mathrm{M}$ glycine, $\mathrm{pH} 2.8 .0 .5 \mathrm{ml}$ fractions were collected and the eluent was immediately neutralized with $1 \mathrm{M}$ Tris, $\mathrm{pH} 8.0(40 \mu \mathrm{l}$ per $0.5 \mathrm{ml}$ fraction). The protein concentration in the elution fractions was monitored as $\mathrm{OD}_{280}$; IgG eluted from the column as a single sharp peak in $2.5 \mathrm{ml}$ volume. For protein concentrating and replacement of elution buffer by binding buffer, these peak fractions were combined and concentrated using a Centricon ${ }^{\circledR}$ concentrator 2 with MWCO $30000 \mathrm{Da}$ (Millipore). The procedure yielded $1 \mathrm{ml}$ of purified $\mathrm{lgG}$ with a protein concentration of $6.56 \mathrm{mg} / \mathrm{ml}$, as determined spectrophotometrically (for $\mathrm{lgG}$ at $280 \mathrm{~nm}$ wave length $1 \mathrm{OD}=0.75 \mathrm{mg} / \mathrm{ml}$ ). Purified $\mathrm{lgG}$ was diluted with binding buffer to adjust the concentration to $1 \mathrm{mg} / \mathrm{ml}$ and was then aliquoted and stored at $-20^{\circ} \mathrm{C}$.

\section{Binding buffer}

$\begin{array}{lll} & \text { For } 200 \mathrm{ml} & \text { Final concentration } \\ \mathrm{NaCl} & 1.75 \mathrm{~g} & 0.15 \mathrm{M} \\ \mathrm{NaH}_{2} \mathrm{PO}_{4} \mathrm{xH}_{2} \mathrm{O} & 0.28 \mathrm{~g} & 10 \mathrm{mM} \\ \mathrm{ddH}_{2} \mathrm{O} & \text { to } 200 \mathrm{ml} & \end{array}$

$\mathrm{pH}$ was adjusted to 7.4.

Washing buffer

For $200 \mathrm{ml}$

Final concentration

$\begin{array}{lll}\mathrm{NaCl} & 1.75 \mathrm{~g} & 0.15 \mathrm{M} \\ \mathrm{NaH}_{2} \mathrm{PO}_{4} \mathrm{xH}_{2} \mathrm{O} & 2.76 \mathrm{~g} & 0.1 \mathrm{M} \\ \mathrm{ddH}_{2} \mathrm{O} & \text { to } 200 \mathrm{ml} & \end{array}$

$\mathrm{pH}$ was adjusted to 7.4. 
Elution buffer

\begin{tabular}{|c|c|c|}
\hline & For $200 \mathrm{ml}$ & Final concentration \\
\hline $\mathrm{NaCl}$ & $1.75 \mathrm{~g}$ & $0.15 \mathrm{M}$ \\
\hline Glycine & $1.5 \mathrm{~g}$ & $0.1 \mathrm{M}$ \\
\hline $\mathrm{dd}_{2} \mathrm{O}$ & to $200 \mathrm{ml}$ & \\
\hline \multicolumn{3}{|c|}{ pH was adjusted to 2.8 . } \\
\hline \multicolumn{3}{|c|}{$\underline{\text { Neutralizing buffer }}$} \\
\hline & For $100 \mathrm{ml}$ & Final concentration \\
\hline Tris- $\mathrm{HCl}$ & $15.76 \mathrm{~g}$ & $1 \mathrm{M}$ \\
\hline $\mathrm{dd}_{2} \mathrm{O}$ & to $100 \mathrm{ml}$ & \\
\hline
\end{tabular}

\subsubsection{Visualization of proteins with silver staining and Coomassie Blue staining}

\section{Silver staining}

The proteins were electrophoretically separated on SDS-PAAG of appropriate percentage and vizualized with silver staining using a protocol described by Blum (Blum et al., 1987). After completion of electrophoresis, the gel was placed in a glass tray, used only for silver staining, and incubated on a rocking platform with solutions sequentially used in the indicated order (Table 1$)$. Per mini slab gel $(8.3 \times 10.2 \mathrm{~cm}), 130$ $\mathrm{ml}$ of each of the solutions indicated in the Table 1 are needed. All solutions were prepared immediately before use.

\section{Stock solutions}

$\underline{10 \% \mathrm{Na}_{2} \underline{\mathrm{SO}}_{4}}$

$$
\text { For } 10 \mathrm{ml}
$$

$\begin{array}{ll}\mathrm{Na}_{2} \mathrm{SO}_{4} & 1 \mathrm{~g} \\ \mathrm{ddH}_{2} \mathrm{O} & \text { to } 10 \mathrm{ml}\end{array}$

The solution can be stored in the dark at $4^{\circ} \mathrm{C}$ for 1 month.

$\underline{1 \mathrm{M} \mathrm{AgNO}_{3}}$

For $10 \mathrm{ml}$
$\mathrm{AgNO}_{3}$
$1.7 \mathrm{~g}$
$\mathrm{ddH}_{2} \mathrm{O}$
to $10 \mathrm{ml}$

The solution can be stored in the dark at $4^{\circ} \mathrm{C}$ for 1 month.

$\underline{37 \% \text { Formalin (ready to use solution) }}$ 
Table 1. Procedure of silver staining

\begin{tabular}{|c|c|c|c|c|}
\hline \multirow[b]{2}{*}{ Step } & \multicolumn{3}{|c|}{ Solutions } & \multirow[b]{2}{*}{ Incubation time } \\
\hline & Components & & $\begin{array}{l}\text { Final } \\
\text { concentration }\end{array}$ & \\
\hline Fixation & $\begin{array}{l}\text { methanol } \\
100 \% \text { acetic acid } \\
\mathrm{ddH}_{2} \mathrm{O}\end{array}$ & $\begin{array}{l}65 \mathrm{ml} \\
15.6 \mathrm{ml} \\
\text { to } 130 \mathrm{ml}\end{array}$ & $\begin{array}{l}50 \% \\
12 \%\end{array}$ & $\begin{array}{l}\text { From } 1 \mathrm{~h} \text { to } \\
\text { overnight }\end{array}$ \\
\hline Washing & $\begin{array}{l}\text { ethanol } \\
\mathrm{ddH}_{2} \mathrm{O}\end{array}$ & $\begin{array}{l}65 \mathrm{ml} \\
\text { to } 130 \mathrm{ml}\end{array}$ & $50 \%$ & $2 \times 20$ minutes \\
\hline Washing & $\begin{array}{l}\text { ethanol } \\
\mathrm{ddH}_{2} \mathrm{O}\end{array}$ & $\begin{array}{l}39 \mathrm{ml} \\
\text { to } 130 \mathrm{ml}\end{array}$ & $30 \%$ & 20 minutes \\
\hline Sensitizing & $\begin{array}{l}10 \% \mathrm{Na}_{2} \mathrm{~S}_{2} \mathrm{O}_{3} \\
\mathrm{ddH}_{2} \mathrm{O}\end{array}$ & $\begin{array}{l}260 \mu \mathrm{l} \\
\text { to } 130 \mathrm{ml}\end{array}$ & $0.02 \%$ & $\begin{array}{l}\text { exactly } 60 \\
\text { seconds }\end{array}$ \\
\hline Washing & $\mathrm{dd} \mathrm{H}_{2} \mathrm{O}$ & & & $3 \times 20$ seconds \\
\hline Silver reaction & $\begin{array}{l}1 \mathrm{M} \mathrm{AgNO}_{3} \\
37 \% \text { formalin } \\
\mathrm{ddH}_{2} \mathrm{O}\end{array}$ & $\begin{array}{l}1.56 \mathrm{ml} \\
91 \mu \mathrm{l} \\
\text { to } 130 \mathrm{ml}\end{array}$ & $\begin{array}{l}12 \mathrm{mM} \\
0.026 \%\end{array}$ & 20 minutes \\
\hline Washing & $\mathrm{dd} \mathrm{H}_{2} \mathrm{O}$ & & & $3 \times 20$ seconds \\
\hline Developing & $\begin{array}{l}\mathrm{Na}_{2} \mathrm{CO}_{3} \\
37 \% \text { formalin } \\
10 \% \mathrm{Na}_{2} \mathrm{~S}_{2} \mathrm{O}_{3} \\
\mathrm{ddH}_{2} \mathrm{O} \\
\text { Stir vigorously to dissolve } \\
\text { sodium carbonate }\end{array}$ & $\begin{array}{l}15 \mathrm{~g} \\
125 \mu \mathrm{l} \\
10 \mu \mathrm{l} \\
\text { to } 250 \mathrm{ml}\end{array}$ & $\begin{array}{l}6 \% \\
0.0185 \% \\
16 \mu \mathrm{M}\end{array}$ & $\begin{array}{l}1 \text { to } 10 \text { minutes } \\
\text { (staining development } \\
\text { should be monitored } \\
\text { closely) }\end{array}$ \\
\hline Stopping & $\begin{array}{l}\text { methanol } \\
100 \% \text { acetic acid } \\
\mathrm{ddH}_{2} \mathrm{O}\end{array}$ & $\begin{array}{l}65 \mathrm{ml} \\
15.6 \mathrm{ml} \\
\text { to } 130 \mathrm{ml}\end{array}$ & $\begin{array}{l}50 \% \\
12 \%\end{array}$ & 20 minutes \\
\hline Storage & $100 \%$ acetic acid & $6.5 \mathrm{ml}$ & $5 \%$ & \\
\hline
\end{tabular}

Alternatively, proteins were stained with Silver Staining Kit (Amersham) according to manufacturer's instructions.

\section{Coomassie Blue staining}

The proteins were electrophoretically separated on the SDS-PAAG of appropriate percentage and vizualized with Coomassie Blue staining. The gel was immersed in a 
sufficient amount of staining solution and agitated on a rocking platform for 2 hours at $\mathrm{RT}$, followed by destaining with destaining solution until the signal/background reached a satisfactory ratio.

Staining solution

\begin{tabular}{|c|c|c|}
\hline & For 11 & Final concentration \\
\hline Coomassie ${ }^{\circledR}$ Brilliant Blue G250 & $5 \mathrm{~g}$ & $0.5 \%$ \\
\hline $100 \%$ acetic acid & $100 \mathrm{ml}$ & $10 \%$ \\
\hline$\beta$-Propanol & $250 \mathrm{ml}$ & $25 \%$ \\
\hline $\mathrm{dd} \mathrm{H}_{2} \mathrm{O}$ & to 11 & \\
\hline \multicolumn{3}{|l|}{ Destaining solution } \\
\hline & For 11 & Final concentration \\
\hline $100 \%$ acetic acid & $100 \mathrm{ml}$ & $10 \%$ \\
\hline$\beta$-Propanol & $250 \mathrm{ml}$ & $25 \%$ \\
\hline $\mathrm{ddH}_{2} \mathrm{O}$ & to 11 & \\
\hline
\end{tabular}

\subsubsection{Preparation of proteins for MALDI-TOF mass spectrometry}

After visualization of the proteins with Coomassie Blue staining, the bands containing the proteins of interest were cut out for identification of these proteins using MALDI-TOF mass spectrometry.

\subsubsection{In-gel digest of proteins stained with Coomassie}

For the description of the procedure see Table 2. All solutions used for the procedure were, unless mentioned, prepared on the day of use.

\section{Stock solutions}

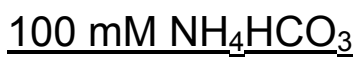

$\begin{array}{ll} & \text { For } 10 \mathrm{ml} \\ \mathrm{NH}_{4} \mathrm{HCO}_{3} & 79 \mathrm{mg} \\ \mathrm{HPLC} \mathrm{H}_{2} \mathrm{O} & \text { to } 10 \mathrm{ml}\end{array}$

$\underline{50 \mathrm{mM} \mathrm{NH}}{ }_{4} \underline{\mathrm{HCO}}_{3}$

$\begin{array}{ll} & \text { For } 10 \mathrm{ml} \\ \mathrm{NH}_{4} \mathrm{HCO}_{3} & 39.503 \mathrm{mg} \\ \mathrm{HPLC} \mathrm{H}_{2} \mathrm{O} & \text { to } 10 \mathrm{ml}\end{array}$


Trypsin stock

Final concentration

$\begin{array}{lll}\text { Trypsin } & 20 \mu \mathrm{g} & 0.1 \mu \mathrm{g} / \mu \mathrm{l} \\ 1 \mathrm{mM}(12 \%) \mathrm{HCl} & 200 \mu \mathrm{l}\end{array}$

The stock solution was dispensed into $5 \mu \mathrm{l}$ aliquots and stored at $-20^{\circ} \mathrm{C}$.

\section{Working solutions}

$\underline{25 \mathrm{mM} \mathrm{NH}} 4 \underline{\mathrm{HCO}_{3}}$

$\begin{array}{ll} & \text { For } 10 \mathrm{ml} \\ 50 \mathrm{mM} \mathrm{NH}_{4} \mathrm{HCO}_{3} & 5 \mathrm{ml} \\ \mathrm{HPLC} \mathrm{H} \mathrm{H}_{2} \mathrm{O} & 5 \mathrm{ml}\end{array}$

$\underline{50 \% \mathrm{AcN} / 25 \mathrm{mM} \mathrm{NH}} \underline{4} \underline{\mathrm{HCO}}_{3}$

\begin{tabular}{ll}
$50 \mathrm{mM} \mathrm{NH}_{4} \mathrm{HCO}_{3}$ & For $1 \mathrm{ml}$ \\
$100 \% \mathrm{AcN}$ & $500 \mu \mathrm{l}$ \\
& $500 \mu \mathrm{l}$ \\
Trypsin-digestion buffer & \\
\hline $100 \mathrm{mM} \mathrm{NH}_{4} \mathrm{HCO}_{3}$ & Total volume $120 \mu \mathrm{l}$ \\
$100 \mathrm{mM} \mathrm{CaCl}_{2}$ & $50 \mu \mathrm{l}$ \\
$\mathrm{HPLC} \mathrm{H} \mathrm{H}_{2} \mathrm{O}$ & $5 \mu \mathrm{l}$ \\
$0.1 \mu \mathrm{\mu l} / \mathrm{l}$ trypsin & $53 \mu \mathrm{l}$ \\
& $12 \mu \mathrm{l}$
\end{tabular}

Table 2. Procedure of in-gel digest of proteins stained with Coomassie Blue

\begin{tabular}{|c|c|c|c|}
\hline \multirow[b]{2}{*}{ Step } & \multicolumn{2}{|c|}{ Solutions } & \multirow{2}{*}{$\begin{array}{l}\text { Incubation time/conditions of } \\
\text { incubation }\end{array}$} \\
\hline & $\begin{array}{c}\mu l \text { per gel } \\
\text { strip }\end{array}$ & Reagent & \\
\hline Washing & $100 \mu \mathrm{l}$ & $\mathrm{HPLC} \mathrm{H}_{2} \mathrm{O}$ & $\begin{array}{l}37^{\circ} \mathrm{C}, 30 \text { minutes; discard the } \\
\text { supernatant afterward }\end{array}$ \\
\hline Washing & $100 \mu \mathrm{l}$ & $\begin{array}{l}25 \mathrm{mM} \\
\mathrm{NH}_{4} \mathrm{HCO}_{3}\end{array}$ & $\begin{array}{l}37^{\circ} \mathrm{C}, 30 \text { minutes; discard the } \\
\text { supernatant afterward }\end{array}$ \\
\hline Washing & $100 \mu \mathrm{l}$ & $\begin{array}{l}50 \% \mathrm{AcN} / 25 \mathrm{mM} \\
\mathrm{NH}_{4} \mathrm{HCO}_{3}\end{array}$ & $\begin{array}{l}37^{\circ} \mathrm{C}, 2 \times 30 \text { minutes; discard the } \\
\text { supernatant afterward }\end{array}$ \\
\hline
\end{tabular}




\begin{tabular}{|c|l|l|l|}
\hline Washing & $100 \mu \mathrm{l}$ & $100 \% \mathrm{AcN}$ & $\begin{array}{l}37^{\circ} \mathrm{C}, 10 \text { minutes; discard the } \\
\text { supernatant afterward }\end{array}$ \\
\hline Drying & & & 5 minutes, room temperature \\
\hline $\begin{array}{c}\text { Trypsin } \\
\text { digestion }\end{array}$ & $25 \mu \mathrm{l}$ & $\begin{array}{l}\text { trypsin } \\
\text { digestion buffer }\end{array}$ & $\begin{array}{l}\text { upon adding trypsin digestion buffer, } \\
\text { keep samples on ice for 15 minutes; } \\
\text { proceed with 18 hours incubation at } \\
37^{\circ} \mathrm{C}\end{array}$ \\
\hline
\end{tabular}

\subsubsection{Extraction of peptides from the gel after trypsin digestion}

\section{Working solutions}

$\underline{1 \% \text { trifluoracetic acid (TFA) }}$

\begin{tabular}{ll}
\hline $100 \%$ TFA & For $10 \mathrm{ml}$ \\
$\mathrm{HPLC} \mathrm{H}_{2} \mathrm{O}$ & $100 \mu \mathrm{l}$ \\
& to $10 \mathrm{ml}$
\end{tabular}

$\underline{0.1 \% \text { TFA }}$

\begin{tabular}{ll}
\hline $1 \%$ TFA & For $10 \mathrm{ml}$ \\
$\mathrm{HPLC} \mathrm{H}_{2} \mathrm{O}$ & $1 \mathrm{ml}$ \\
& to $10 \mathrm{ml}$
\end{tabular}

\section{Procedure}

After the trypsin digestion was completed, the tubes with the samples were shortly centrifuged in an Eppendorf bench-top MiniSpin centrifuge and the supernatants transferred to new tubes. $50 \mu \mathrm{l}$ of $1 \%$ TFA was added to each sample and the mixture was incubated for 30 minutes at $37^{\circ} \mathrm{C}$ for peptide extraction. To make the latter more efficient, the samples were sonicated for 10 minutes at room temperature. After short centrifugation, the supernatants were recovered and pooled with the first supernatant of the corresponding sample. The samples were lyophilized in a speed vac concentrator (for 1 hour and 15 minutes). The obtained lyophilisates were reconstituted in $10 \mu \mathrm{l}$ of $0.1 \%$ TFA and sonicated at room temperature for 5 minutes. Prepared samples were then subjected to ZipTip purification.

\subsubsection{ZipTip purification}

\section{Working solutions}

$\underline{50 \% \mathrm{AcN}}$ 
For $1 \mathrm{ml}$

$100 \%$ AcN

$500 \mu \mathrm{l}$

HPLC $\mathrm{H}_{2} \mathrm{O}$

$500 \mu \mathrm{l}$

$1 \%$ TFA

$100 \%$ TFA

For $1 \mathrm{ml}$

HPLC $\mathrm{H}_{2} \mathrm{O}$

$10 \mu \mathrm{l}$

to $1 \mathrm{ml}$

$\underline{0.1 \% \text { TFA }}$

1\% TFA

For $1 \mathrm{ml}$

$\mathrm{HPLC} \mathrm{H}_{2} \mathrm{O}$

$100 \mu \mathrm{l}$

to $1 \mathrm{ml}$

$\underline{0.1 \% \mathrm{TFA} / 50 \% \mathrm{AcN}}$

For $1 \mathrm{ml}$

1\% TFA

$100 \mu \mathrm{l}$

$100 \%$ AcN

$500 \mu \mathrm{l}$

HPLC $\mathrm{H}_{2} \mathrm{O}$

to $1 \mathrm{ml}$

Prepare Eppendorf tubes of indicated size filled with the following solutions:

\begin{tabular}{|l|l|l|}
\hline \multirow{2}{*}{$\begin{array}{l}\text { Number }(\mathrm{n}) \text { and size of tubes } \\
\text { ( } \begin{array}{l}\text { n of tubes corresponds to } \\
\text { number of the samples) }\end{array}\end{array}$} & Amount per tube & Reagents \\
\cline { 2 - 3 } & & $50 \%$ AcN \\
\hline $1 \times 1.5 \mathrm{ml}$ & $1 \mathrm{ml}$ & $0.1 \%$ TFA \\
\hline $1 \times 1.5 \mathrm{ml}$ & $1 \mathrm{ml}$ & $0.1 \%$ TFA \\
\hline $\mathrm{n} \times 0.5 \mathrm{ml}$ & $100 \mu \mathrm{l}$ & $0.1 \% \mathrm{TFA} / 50 \% \mathrm{AcN}$ \\
\hline $\mathrm{n} \times 0.2 \mathrm{ml}$ & $10 \mu \mathrm{l}$ & \\
\hline
\end{tabular}

\section{Procedure}

ZipTip purification of peptides extracted from the gel utilizes ZipTip ${ }^{\circledR}$ pipette tips (Millipore) containing $\mathrm{C}_{18}$ reverse-phase medium for desalting and concentrating peptides.

Using the pipettor set at $10 \mu \mathrm{l}$, the ZipTip pipette tip was first equilibrated by aspirating and dispensing $10 \mu \mathrm{l}$ of $50 \% \mathrm{AcN}$, followed by equilibration with $10 \mu \mathrm{l}$ of $0.1 \%$ TFA. The aspiration-dispensing cycle was repeated 7 times on each occasion. After equilibration 
of the chromatography medium, the peptides were bound to the bed by aspirating and dispensing sample 20 times. For washing, $10 \mu \mathrm{l}$ of $0.1 \%$ TFA were aspirated and dispensed 7 times. To elute the sample, $10 \mu \mathrm{l}$ of $0.1 \% \mathrm{TFA} / 50 \%$ AcN were carefully aspirated and dispensed through the ZipTip pipette tip 5 times without introducing air into the sample.

After this procedure, purified samples were concentrated in a speed vac concentrator for 5 minutes down to $3 \mu \mathrm{l}$. An aliquot was spotted onto a MALDI-TOF MS target.

\subsection{GST fusion protein pulldown assay}

\subsubsection{Transformation of bacteria, growth and induction}

Escherichia coli BL-21 were transformed with human FKBP12-pGEX-6P-3 or FKBP12.6-pGEX-6P-3 constructs, coding for corresponding GST fusion proteins. For the transfection, $50 \mu$ aliquots of BL-21 were thawed and DNA was added to the cells. Afterwards, this mixture was transferred into a pre-chilled electroporation cuvette. The cuvette was placed in the electroporator and pulse was applied. Immediately after transfection, SOC medium was added to the cells; the cells in SOC medium were transferred into sterile tubes and incubated at $180 \mathrm{rpm}$ for 30 minutes at $37^{\circ} \mathrm{C}$. After incubation, the mixture was centrifuged in an Eppendorf bench-top MiniSpin centrifuge at $6000 \mathrm{rpm}$ for 2 minutes. The supernatant was transferred into a new tube and the pellet was resuspended in $200 \mu \mathrm{l}$ of the obtained supernatant. $200 \mu \mathrm{l}$ from this suspension was used for plating the cells on agar dish, containing ampicillin.

After overnight growth at $37^{\circ} \mathrm{C}$, single colonies were obtained, two of which were picked and inoculated into $3 \mathrm{ml}$ of LB medium, containing ampicillin $(100 \mu \mathrm{g} / \mathrm{ml})$, for further overnight pregrowth at $37^{\circ} \mathrm{C}$ under continuous shaking at $180 \mathrm{rpm} .1 \mathrm{ml}$ of the obtained bacterial suspension was mixed with an equal volume of sterile glycerol and stored at $-80^{\circ} \mathrm{C}$ as a stock. The remaining $2 \mathrm{ml}$ were used to inoculate $200 \mathrm{ml}$ of ampicillincontaining LB medium. The cells were growing at $37^{\circ} \mathrm{C}$ to mid-log phase $\left(\mathrm{OD}_{600}-0.6-\right.$ 1.0) with continuous shaking of the suspension at $140 \mathrm{rpm}$. To provide sufficient aeration, culturing was carried out in one-liter flasks. The first OD measurement was performed after 1 hour of incubation, using ampicillin-containing LB medium as a blank reference. Typically, after 3 and a half hours the $\mathrm{OD}_{600}$ reaches the desired value (0.7). Afterwards, the expression of the recombinant protein was induced by adding isopropyl$\beta$-D-thiogalactoside (IPTG) to a final concentration of $1 \mathrm{mM}$. Prior to induction the temperature was decreased to $30^{\circ} \mathrm{C}$ to prevent the formation of inclusion bodies. The 
cells were allowed to grow for an additional 4 hours at $30^{\circ} \mathrm{C}$. After every hour, $1 \mathrm{ml}$ aliquots were harvested in order to estimate the time sufficient for effective overexpression of the recombinant protein. After 4 hours, the suspension was transferred to $250 \mathrm{ml}$ plastic bottles $\left(\right.$ Sorvall ${ }^{\circledR}$ ) and cells were harvested by centrifugation at $6000 \mathrm{rpm}$ in a Sorvall ${ }^{\circledR}$ SLA-1500 rotor. The supernatant was discarded and the pellet was frozen and kept at $-20^{\circ} \mathrm{C}$ until purification of the overexpressed fusion protein. Pellets harvested after every hour of expression time were resuspended in $100 \mu \mathrm{l}$ of $5 \mathrm{X}$ sample buffer and $20 \mu \mathrm{l}$ aliquots were analyzed by SDS-PAGE followed by Coomassie Blue staining.

Media and solutions used for E. coli transformation and cultivation

$\underline{\text { soc medium }}$

$0.5 \%$ yeast extract

$2 \%$ bacto-trypton

$10 \mathrm{mM} \mathrm{NaCl}$

$2.5 \mathrm{mM} \mathrm{KCl}$

$10 \mathrm{mM} \mathrm{MgSO}_{4}$

$10 \mathrm{mM} \mathrm{MgCl}_{2}$

$20 \mathrm{mM}$ glucose

\section{Luria Bertani (LB) medium}

\section{For 1 I}

Bacto-trypton

$10 \mathrm{~g}$

Yeast extract $5 \mathrm{~g}$

$\mathrm{NaCl}$

$5 \mathrm{~g}$

$\mathrm{ddH}_{2} \mathrm{O}$

to 11

$\mathrm{pH}$ was adjusted with $\mathrm{NaOH}$ to 7.3 , the medium was sterilized by autoclaving and stored at $4^{\circ} \mathrm{C}$.

\section{LB-ampicillin agar dishes}

Bactoagar was added to the LB medium to a final concentration of $1.5 \%$, followed by autoclaving. Afterwards, the medium was let cool down to $55^{\circ} \mathrm{C}$ and ampicillin was added to a final concentration of $100 \mu \mathrm{g} / \mathrm{ml}$. This medium was poured into $10 \mathrm{~cm}$ sterile Petri-dishes in a sterile bench and left undisturbed for about 30 minutes to solidify. LB-agar dishes were stored in the dark at $4^{\circ} \mathrm{C}$. 


\section{Ampicillin stock solution}

Ampicillin

$100 \mathrm{mg} / \mathrm{ml}$

The powder was dissolved in sterile $\mathrm{ddH}_{2} \mathrm{O} ; \mathrm{pH}$ was adjusted with $\mathrm{HCl}$ to $7.0 ; 500 \mu \mathrm{l}$ aliquots were stored at $-20^{\circ} \mathrm{C}$.

$\underline{\text { IPTG stock }}$

Final concentration

IPTG $\quad 500 \mathrm{mg} \quad 100 \mathrm{mM}$

Sterile $\mathrm{ddH}_{2} \mathrm{O} \quad 20 \mathrm{ml}$

IPTG dissolved in sterile $\mathrm{H}_{2} \mathrm{O}$ was dispensed into $1 \mathrm{ml}$ aliquots and stored at $-20^{\circ} \mathrm{C}$.

\subsubsection{Purification of fusion proteins}

\section{Preparation of cell extract}

The pellets from $200 \mathrm{ml}$ culture (see 3.5.1) of the bacterial cells containing overexpressed fusion protein were resuspended in $10 \mathrm{ml}$ of ice-cold PBS, $\mathrm{pH} 7.4$ followed by sonication. The cells were sonicated on ice in short bursts lasting for 1 second. $10 \times 10$ bursts were sufficient to disrupt the cells without destroying protein functionality. For effective solubilization of the recombinant proteins, Triton $\mathrm{X}-100$ at a final concentration of $1 \%$ was added to the cell suspension followed by gentle agitation of the mixture at room temperature for 30 minutes using an end-over-end rotator. The crude extract was centrifuged at $10000 \mathrm{~g}$ for 5 minutes at $4^{\circ} \mathrm{C}$. The supernatant was used for subsequent purification of the fusion protein. Aliquots from each stage of the cell extract preparation were analyzed by SDS-PAGE followed by Coomassie staining.

\section{Purification of GST-tagged fusion proteins using Glutathione Sepharose Fast Flow}

One step purification of the GST-tagged fusion proteins is based on the affine interaction between glutathione S-transferase tag of the recombinant protein and glutathione coupled to the sepharose, and consists of binding the fusion protein to the glutathione-sepharose, washing the matrix to remove nonspecifically bound proteins, and elution of the recombinant protein in a buffer containing $10 \mathrm{mM}$ reduced glutathione. For the purification described here, GSTrap columns operated with a syringe (Amersham Biosciences) were utilized. 
Column of $1 \mathrm{ml}$ volume was connected to a syringe according to manufacturer's instructions and equilibrated with $5 \mathrm{ml}$ of PBS, pH 7.4 at a flow rate of $2 \mathrm{ml} / \mathrm{min}$. Sample, prepared as above and filtered through a $0.45 \mu \mathrm{m}$ filter just before use, was applied to the column at a flow rate of $1 \mathrm{ml} / \mathrm{min}$. Next, the column was washed with $10 \mathrm{ml}$ PBS at a flow rate of $2 \mathrm{ml} / \mathrm{min}$ to wash away nonspecifically bound material. $1 \mathrm{ml}$ fractions were collected and $20 \mu \mathrm{l}$ aliquots from each fraction were picked for SDS-PAGE. The recombinant protein was eluted from the column with $10 \mathrm{ml}$ of elution buffer $(10 \mathrm{mM}$ glutathione in $50 \mathrm{mM}$ Tris- $\mathrm{HCl}, \mathrm{pH} \mathrm{8.0)}$ passed through the column at a flow rate of 1 $\mathrm{ml} / \mathrm{min} .1 \mathrm{ml}$ elution fractions were collected and $20 \mu \mathrm{l}$ aliquots were analyzed by SDSPAGE followed by Coomassie staining. Typically, recombinant protein was eluted as a sharp peak consisting of fractions number 2-4 and this elution profile was identical for all performed preparations. Finally, the column was washed with $20 \mathrm{ml}$ PBS until no material appeared in the effluent and stored under PBS at $4^{\circ} \mathrm{C}$ until next use. Three fractions containing the peak of the recombinant protein were pooled and dialyzed twice against 5 I of PBS each time with a change after 4 hours using Spectra/Por ${ }^{\circledR}$ Cellulose Ester dialysis beg (Spectrum, MWCO $1000 \mathrm{Da}$ ). The concentration of the purified recombinant GST fusion protein was estimated using a BCA kit (Pierce Chemical Co) and the protein yield per one preparation typically averaged $1 \mathrm{ml}$ with a concentration of 6-7 $\mathrm{mg} / \mathrm{ml}$. The protein was aliquoted and stored at $-80^{\circ} \mathrm{C}$.

\section{Lysis buffer}

10X PBS

Triton X-100

$\mathrm{ddH}_{2} \mathrm{O}$
For $100 \mathrm{ml}$

$10 \mathrm{ml}$

$1 \mathrm{ml}$

to $100 \mathrm{ml}$

\section{Elution buffer}
Reduced glutathione
$0.154 \mathrm{~g}$
50 mM Tris- $\mathrm{HCl}$, pH 8.0
$50 \mathrm{ml}$

Final concentration

Final concentration

$1 \mathrm{X}$

$1 \%$

The solution was dispensed into aliquots and stored at $-20^{\circ} \mathrm{C}$. Freezing-thawing cycles should be avoided.

\section{$\underline{1 \mathrm{XPBS}}$}

For 10 I

10X PBS

11

$\mathrm{ddH}_{2} \mathrm{O}$

to 10 I 


\subsubsection{GST fusion protein pulldown assay}

The GST fusion protein pulldown technique for the detection of protein-protein interactions uses the affinity of GST for glutathione-coupled beads to purify interacting proteins from a solution of non-interacting proteins. The principal scheme of a GST pulldown applicable to study of FKBP-RyR interaction is depicted in Figure 8. The GST fusion probe protein is expressed and purified as described before. In parallel the sample containing the target protein is prepared. The latter can be cell/tissue crude lysate or a fraction enriched with a protein of interest. The GST fusion protein probe and the sample containing the target protein are mixed in the presence of glutathione-sepharose beads and incubated to allow protein association to occur. The GST fusion probe protein and any associated molecules are collected by centrifugation and the complexes are washed. Finally the complexes are eluted from the beads with excess free glutathione. The proteins are resolved by SDS-PAGE and processed for further analysis by immunoblotting or protein staining.

The procedure described here is an adaptation of the GST-FKBP12 affinity chromatography previously described by Xin et al. (Xin et al., 1995).

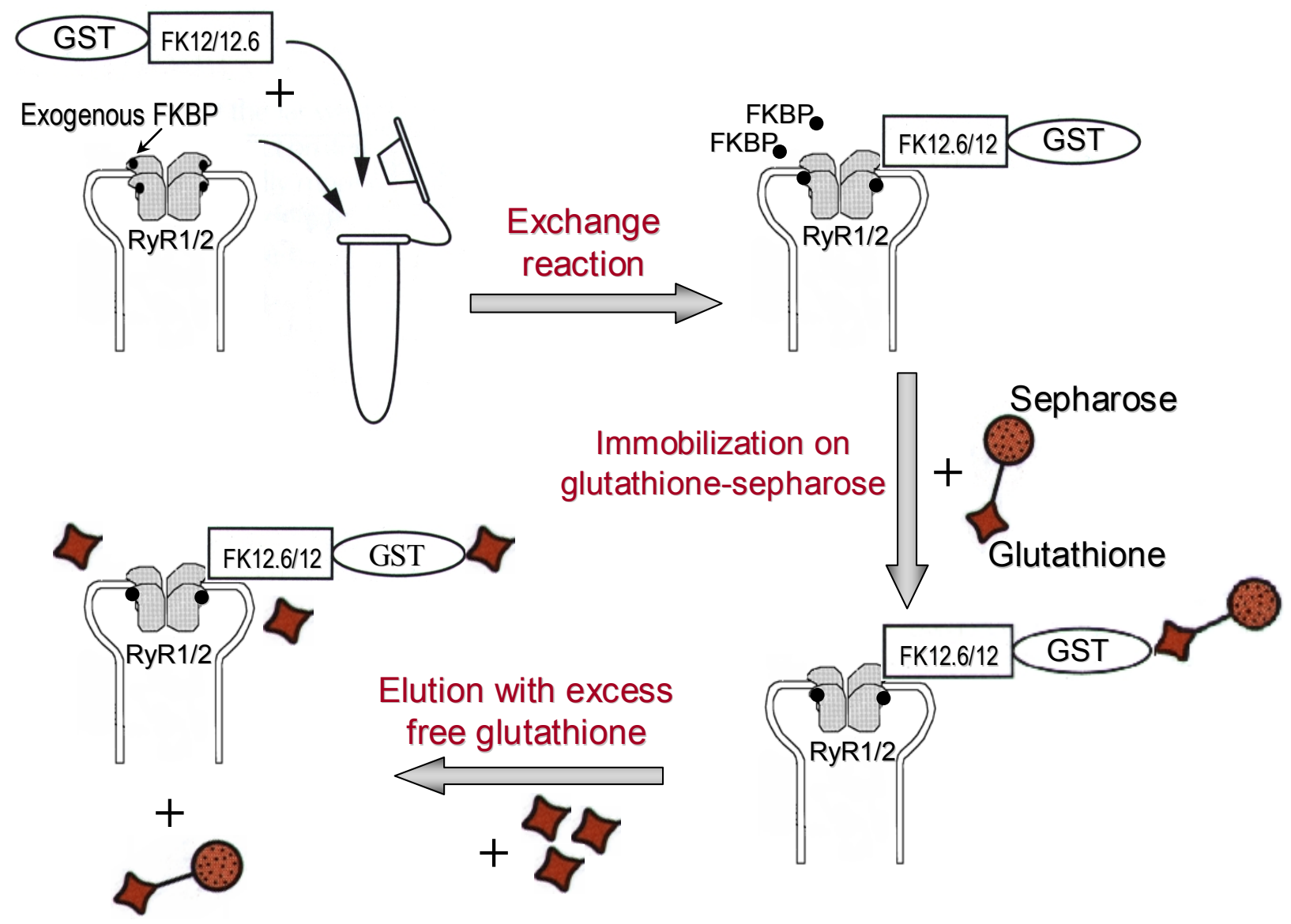

Figure 8. Scheme of GST pulldown assay designed for precipitation of ryanodine receptor based on its specific association with GST-FKBPs. For explanations see the text. 
Preparation of cell lysates and cardiac homogenates

Isolated rabbit ventricular myocytes ( 1 million cells per probe) were suspended by pipetting in $500 \mu \mathrm{l}$ of modified RIPA buffer containing $50 \mathrm{mM}$ Tris- $\mathrm{HCl}, \mathrm{pH} \mathrm{7.4,0.9 \%}$ $\mathrm{NaCl}, 0.25 \%$ Triton $\mathrm{X}-100$ and supplemented with $1 \mathrm{mM} \mathrm{NaF}, 1 \mathrm{mM} \mathrm{Na}_{3} \mathrm{VO}_{4}$ and protease inhibitors. After keeping the samples for 30 minutes on ice with occasional vortexing, they were passed 5 times through a $21 \mathrm{G}$ injection canula connected to a syringe.

Cardiac homogenates from canine hearts and from human hearts explanted from patients with IDCMP, undergoing cardiac transplantation, were prepared as follows: tissue (up to $1 \mathrm{gram}$ ), free from fibrosis and trimmed of fat, connective tissue and vessels, was homogenized in 1 volume of homogenization buffer, comprised of $50 \mathrm{mM}$ Tris- $\mathrm{HCl}, \mathrm{pH}$ 7.4, $200 \mathrm{mM} \mathrm{NaCl}, 20 \mathrm{mM} \mathrm{NaF}, 1 \mathrm{mM} \mathrm{Na} \mathrm{VO}_{4}, 1 \mathrm{mM}$ DTT and supplemented with protease inhibitors, using mechanically driven Potter-Elvehjem tissue grinder with a tightly fitted Teflon pestle. The tissue was processed until a homogenous consistence was reached. The prepared homogenates were suspended in $5 \mathrm{X}$ modified RIPA buffer, mixing 4 volumes of homogenate with 1 volume of the $5 \mathrm{X}$ modified RIPA buffer. The mixture was solubilized on ice for 30 minutes with occasional vortexing.

The prepared cell lysates and tissue homogenates were centrifuged at $3000 \mathrm{~g}$ for 10 minutes at $4^{\circ} \mathrm{C}$. The supernatants were used for GST pulldown assay.

Probing of samples containing the target protein and detection of the interacting proteins

Typically one set of the pulldown experiment consisted of the samples incubated with probe protein (GST-FKBP12.6 or GST-FKBP12) and several negative controls including incubation with GST and glutathione-sepharose beads only to exclude nonspecific binding of the target protein (RyR2) to GST moiety of the recombinant protein or to the glutathione-sepharose beads, respectively. In each case, an equal amount of the sample containing the target protein was used in the reaction. To all tubes, containing $500 \mu \mathrm{l}$ of the suspension with target protein, $50 \mu \mathrm{l}$ of reconstituted in PBS $50 \%$ glutathione-sepharose was added; probe protein (either GST-FKBP12.6 or GSTFKBP12) was added at amount of $30 \mu \mathrm{g}$. Another two samples were incubated with $30 \mu \mathrm{g}$ of the recombinant GST protein (GST negative control) or with glutathione-sepharose beads only (sepharose beads control). During incubation for 5 hours at $4^{\circ} \mathrm{C}$, complexes between the probe and target proteins were formed and 
caught by glutathione-sepharose. Formed complexes were recovered by centrifugation for 2 minutes using an Eppendorf bench-top MiniSpin centrifuge set at maximum speed and washed 3 times with $250 \mu$ of ice-cold lysis buffer. Between washings, the complexes were recovered by centrifugation for 1 minute at maximum speed of an Eppendorf centrifuge. Finally GST fusion protein and any proteins bound to it were eluted in $75 \mu$ l of elution buffer (10 mM reduced glutathione in $50 \mathrm{mM}$ Tris- $\mathrm{HCl}, \mathrm{pH}$ 8.0) for 15 minutes at room temperature. For one preparation, $60 \mu \mathrm{M}$ FK506, which specifically prevents the interaction between ryanodine receptor and FK506-binding proteins, was used to elute RyR2. This sample served as an additional control to confirm the specificity of interaction. Ethanol, the solvent for FK506, was applied in parallel to another identical sample. To recover the eluents, tubes were centrifuged for 2 minutes at maximum speed of an Eppendorf centrifuge and supernatants containing GST fusion protein and target proteins bound to it, were transferred to new tubes. Aliquots from the eluates as well as from the intermediate fractions were analyzed by SDS-PAGE followed by silver staining and immunoblotting.

Modified RIPA buffer

$\begin{array}{lll} & \text { For } 50 \mathrm{ml} & \text { Final concentration } \\ 2 \mathrm{M} \mathrm{Tris-HCl}, \mathrm{pH} 7.4 & 1.25 \mathrm{ml} & 50 \mathrm{mM} \\ 4 \mathrm{M} \mathrm{NaCl} & 1.93 \mathrm{ml} & 154 \mathrm{mM} \\ \text { Triton X-100 } & 125 \mu \mathrm{l} & 0.25 \% \\ \mathrm{ddH}_{2} \mathrm{O} & \text { to } 50 \mathrm{ml} & \end{array}$

Modified RIPA buffer with additives (prepared just prior to use)

Final concentration

$\begin{array}{lll}\text { Modified RIPA buffer } & 5 \mathrm{ml} & \\ 200 \mathrm{mM} \mathrm{NaF} & 25 \mu \mathrm{l} & 1 \mathrm{mM} \\ 100 \mathrm{mM} \mathrm{Na}_{3} \mathrm{VO}_{4} & 50 \mu \mathrm{l} & 1 \mathrm{mM} \\ 100 \mathrm{mM} \text { pefabloc SC } & 10 \mu \mathrm{l} & 0.2 \mathrm{mM} \\ 1 \mathrm{mM} \text { aprotinin } & 0.5 \mu \mathrm{l} & 100 \mathrm{nM} \\ 10 \mathrm{mM} \text { leupeptin } & 0.5 \mu \mathrm{l} & 1 \mu \mathrm{M} \\ 1.4 \mathrm{mM} \text { pepstatin A } & 3.5 \mu \mathrm{l} & 1 \mu \mathrm{M} \\ 1 \mathrm{M} \text { benzamidine } & 5 \mu \mathrm{l} & 1 \mathrm{mM} \\ 12.5 \mathrm{mM} \text { calpain inhibitor I } & 0.4 \mu \mathrm{l} & 1 \mu \mathrm{M} \\ 12.5 \mathrm{mM} \text { calpain inhibitor II } & 0.4 \mu \mathrm{l} & 1 \mu \mathrm{M}\end{array}$


Homogenization buffer with additives (for tissue processing; prepared just prior to use)

For $5 \mathrm{ml}$

2 M Tris- $\mathrm{HCl}, \mathrm{pH} 7.4$

$4 \mathrm{M} \mathrm{NaCl}$

$200 \mathrm{mM} \mathrm{NaF}$

$100 \mathrm{mM} \mathrm{Na}_{3} \mathrm{VO}_{4}$

$100 \mathrm{mM}$ DTT

$100 \mathrm{mM}$ pefabloc SC

$1 \mathrm{mM}$ aprotinin

10 mM leupeptin

$1.4 \mathrm{mM}$ pepstatin A

$1 \mathrm{M}$ benzamidine

$12.5 \mathrm{mM}$ calpain inhibitor I

$12.5 \mathrm{mM}$ calpain inhibitor II

$\mathrm{dd} \mathrm{H}_{2} \mathrm{O}$
$125 \mathrm{ml}$

$250 \mathrm{ml}$

$500 \mu \mathrm{l}$

$50 \mu \mathrm{l}$

$50 \mu \mathrm{l}$

$10 \mu \mathrm{l}$

$0.5 \mu \mathrm{l}$

$0.5 \mu \mathrm{l}$

$3.5 \mu \mathrm{l}$

$5 \mu \mathrm{l}$

$0.4 \mu \mathrm{l}$

$0.4 \mu \mathrm{l}$

to $5 \mathrm{ml}$
Final concentration

$50 \mathrm{mM}$

$200 \mathrm{mM}$

$20 \mathrm{mM}$

$1 \mathrm{mM}$

$1 \mathrm{mM}$

$0.2 \mathrm{mM}$

$100 \mathrm{nM}$

$1 \mu \mathrm{M}$

$1 \mu \mathrm{M}$

$1 \mathrm{mM}$

$1 \mu \mathrm{M}$

$1 \mu \mathrm{M}$

\section{Elution buffer}

Final concentration

Reduced glutathione

$0.154 \mathrm{~g}$

$10 \mathrm{mM}$

50 mM Tris- $\mathrm{HCl}, \mathrm{pH} 8.0$

$50 \mathrm{ml}$

The solution was dispensed into $500 \mu \mathrm{l}$ aliquots and stored at $-20^{\circ} \mathrm{C}$. Freezing-thawing cycles should be avoided.

\subsection{Safety measures}

All operations with genetically modified organisms and plasmid DNA were performed in accordance to the "Gentechnikgesetz" of 1990 and to the rules prescribed by the "Gentechnik-Sicherheitsverordnung" of 1990. Materials contaminated with bacterial cells were desinfected with Mucocit ${ }^{\circledR}$ (Merz/Frankfurt) and autoclaved.

All operations with adenoviruses were performed in level S2 and S1 laboratories in accordance to the GenTSV. Materials contaminated with adenoviruses were desinfected with Desomedan ${ }^{\circledR}$ (Desomed/Freiburg) and autoclaved.

Ethidium bromide and silver nitrate, chemicals deleterious for the environment, when used in the course of the work, were carefully managed and disposed properly in accordance with institutional guidelines. 


\subsection{Statistical analysis}

Results of contractility measurements are presented as mean \pm sem. Myocyte-shortening data obtained from normal cardiomyocytes were analyzed by Student's $t$-test for paired values. Myocyte-shortening data obtained from cardiomyocytes isolated from rabbit failing hearts and hearts of sham-operated rabbits were analyzed by Student's $t$-test for unpaired values. $P<0.05$ was accepted as statistically significant.

Immunoreactive protein bands were evaluated densitometrically using a Multilmage Light System (Alpha Innotech Corporation). To compare total levels of RyR2 in sham and failing rabbit hearts, the amounts of RyR2 in respective samples were determined by densitometric quantification of the immunoblots and normalized for the amount of calsequestrin. Each individual value represents the mean of two independent determinations. Data were analyzed by Student's $t$-test for unpaired values and presented as mean \pm sem. $P<0.05$ was accepted as statistically significant.

To assess levels of FKBP12.6 associated with RyR2 in sham and failing rabbit hearts, the amounts of FKBP12.6 co-immunoprecipitating with RyR2 in respective samples were determined densitometrically and normalized for the amount of RyR2 immunoprecipitated. Data were analyzed by Student's $t$-test for unpaired values and presented as mean \pm sd. $P<0.05$ was accepted as statistically significant. 


\section{Results}

\subsection{Verification of virus transfection efficiency and transgene expression levels}

To clarify the physiological role of FKBP12, adenovirus-mediated gene transfer was used to overexpress FKBP12 in isolated rabbit ventricular cardiomyocytes. Prior to physiological measurements of the overexpression effect, experiments on verification of virus transfection efficiency and transgene expression were performed.

\subsubsection{Verification of virus transfection efficiency in $\beta$-galactosidase reporter gene assay}

Efficiency of adenoviral gene transfer in isolated rabbit ventricular myocytes was initially verified in a $\beta$-galactosidase reporter gene assay (Fig. 9). Cardiomyocytes, isolated from rabbit heart, were infected with the LacZ virus, coding for $\beta$-galactosidase, at a multiplicity of infection (MOI) of 1, 10, 50 and 100. $\beta$-Galactosidase assay performed 48 hours post transfection revealed an increase in the ratio of stained to unstained cells with increasing amounts of virus, reaching $95 \%$ at a $\mathrm{MOI}$ of 10 (Table 3 ).

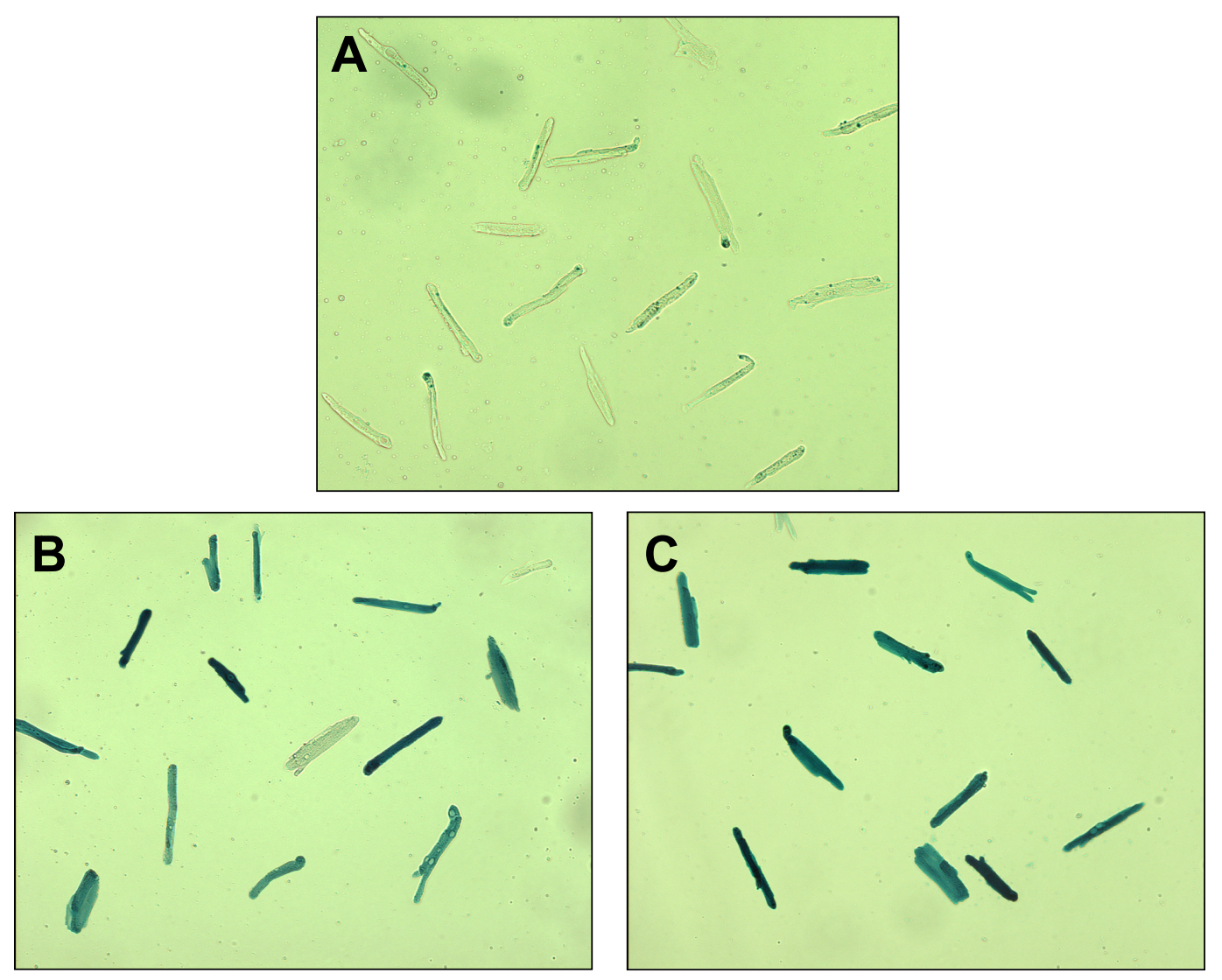

Figure 9. $\beta$-Galactosidase reporter gene assay performed 48 hours post transfection. Nontransfected control (A), $\beta$-galactosidase activity in cells transfected with Ad-LacZ at MOI 10 (B) and $\mathrm{MOI} 100$ (C). For a more precise determination of transfection efficiency see Table 3. 
Table 3. Numerical expression of results obtained in $\beta$-gal reporter gene assay.

\begin{tabular}{|c|c|}
\hline MOI & $\begin{array}{c}\text { Efficiency of } \\
\text { transfection }(\%)\end{array}$ \\
\hline 0,1 & 7,69 \\
\hline 1 & 42,86 \\
\hline 10 & 95,24 \\
\hline 100 & 100 \\
\hline
\end{tabular}

\subsubsection{Validation of transgene expression at mRNA and protein levels}

For overexpression of FKBP12, an adenovirus (Ad) coding for full length human FKBP12 was used. Cells were transfected at different $\mathrm{MOI}$, cultured for 48 hours and harvested for total RNA isolation and preparation of total protein lysates. RT-PCR with primers specific for human FKBP12 revealed an increase in transgene mRNA levels in a dose-dependent manner (Fig. 10A, upper panel). Duplex calsequestrin (CS)-glyceraldehyde-3-phosphate dehydrogenase (GAPDH) RT-PCR was used to control for equal loading (Fig. 10A, lower panel). RT-PCR with primers specific for rabbit FKBP12 showed no changes of endogenous FKBP12 (Fig. 10A, middle panel).

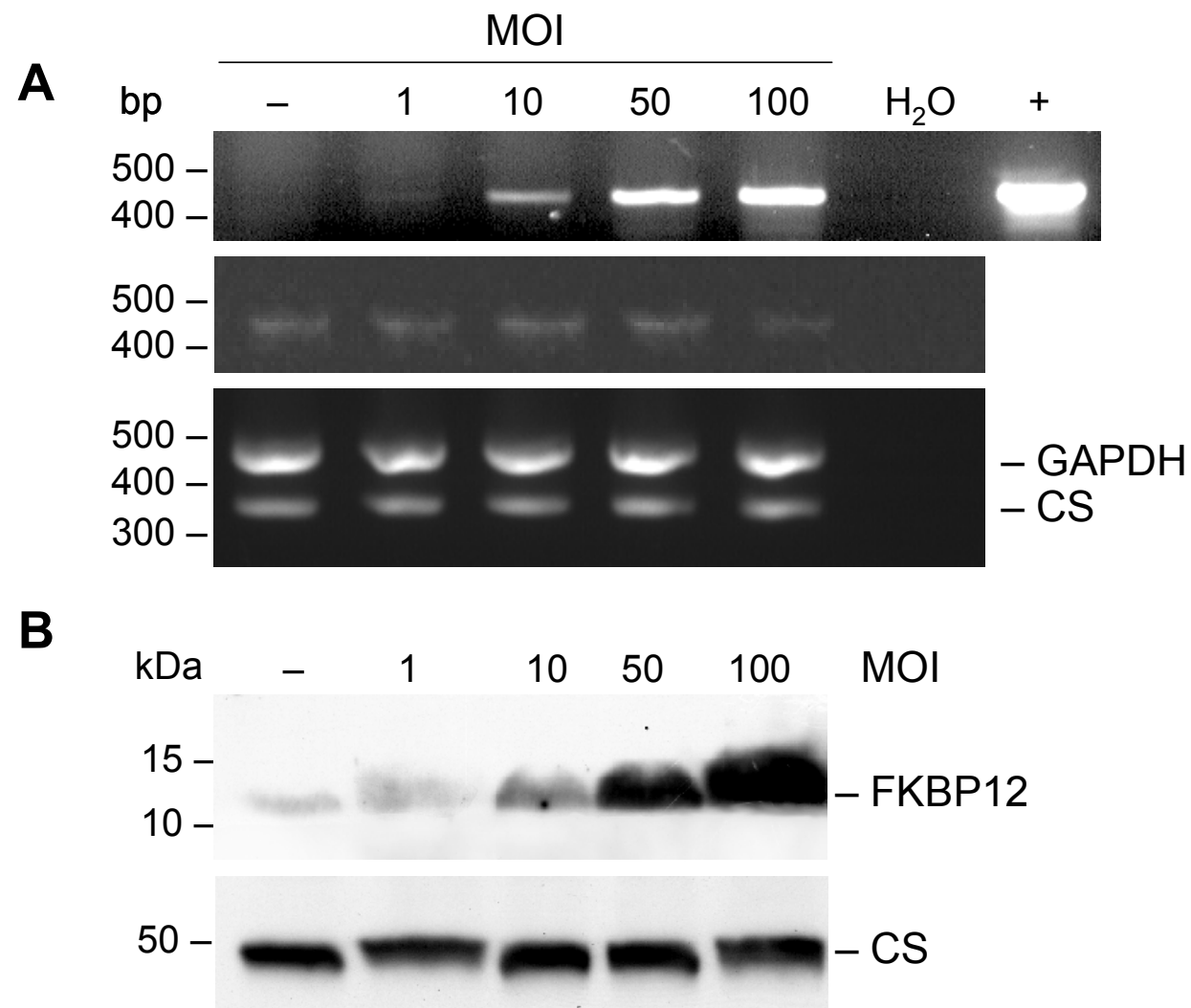

Figure 10. Verification of transgene (FKBP12) expression at mRNA and protein levels. (A) RT-PCR analysis of Ad-FKBP12 infected myocytes. Cells were infected the indicated $\mathrm{MOI}$ and harvested 48 hours post transfection. The size of DNA markers is indicated in the left margin. + denotes positive control with FKBP12 plasmid DNA as template. Duplex RT-PCR (bottom panel) with GAPDH and CS specific primers using the same samples indicates equal cDNA load in each PCR. (B) Western blot analysis of Ad-FKBP12 infected myocytes with antiFKBP12 antibody. Cells were infected with indicated $\mathrm{MOI}$ and harvested 48 hours after transfection. Western blot analysis with anti-calsequestrin antibody (bottom panel) using the same probes indicates equal protein load in each well. 
Immunoblotting with C-19 antibody (Santa Cruz) confirmed overexpression of FKBP12 at the protein level (Fig. 10B, upper panel). CS served as control of equal loading (Fig. 10B, lower panel). For subsequent physiological measurements, cells were infected with Ad-FKBP12 and Ad-LacZ (the latter serving as control virus) at an MOI of 100.

Thus, high efficiency of transfection and isoform specific transient overexpression were achieved. To ensure effective overexpression of the transgene, the cells, for further physiological measurements, were transfected at $\mathrm{MOI}$ of 100 , which, as shown in Figure 10, provides abundant but not excessive production of the exogenous FKBP12.

\subsection{Contractility measurements of rabbit cardiomyocytes transfected with Ad-FKBP12}

Single cell shortening of Ad-FKBP12 and Ad-LacZ infected cardiomyocytes was measured 48 hours after adenoviral transfection by video-edge-detection system as described in Methods (3.3). The cells selected for data analysis had clear striation, rodshaped form (as depicted in Figure 11A) and stable diastolic length.

A

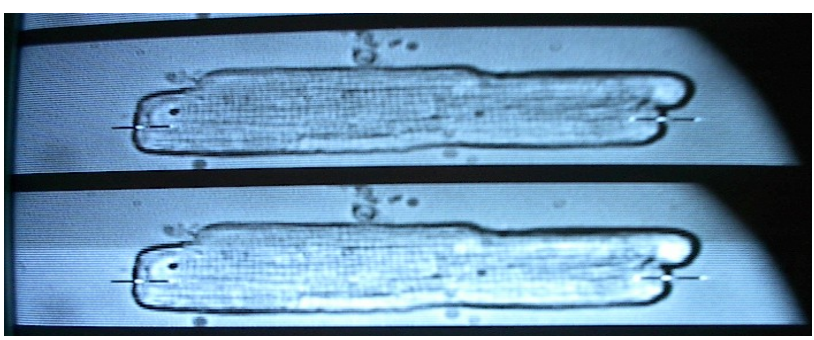

B

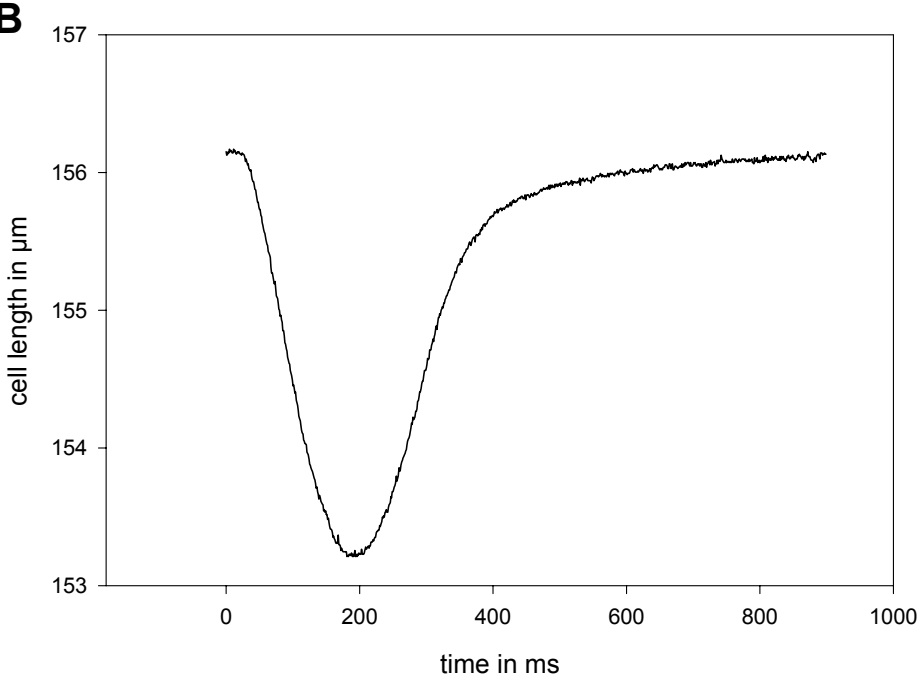

Figure 11. (A) Image of an isolated rabbit ventricular cardiomyocyte. In the course of single cell shortening measurements, the image of rabbit ventricular cardiomyocytes was recorded using a CCD camera and displayed on a TV monitor. The cell depicted and selected for data analysis met morphological requirements such as clear striation and rod-shaped form. (B) Representative tracing of shortening experiments with transfected cardiomyocytes. The graph shows the time-course of cell length during one systole-diastole cycle. 
Figure 12 summarizes the results of contractility measurements 48 hours post transfection. Cardiomyocytes overexpressing FKBP12 showed a statistically significant increase in fractional shortening (by 14\%) compared to LacZ-transfected myocytes, which served as control $(2.4 \pm 0.3 \%$ vs. $2.1 \pm 0.2 \%$, respectively, $n=12$ isolations (each $\sim 10-15$ cells), $p<0.05$ ) (Fig. 12). The significant effect of FKBP12 overexpression on contractility provides physiological evidence of the role of FKBP12 in the modulation of cardiac excitation-contraction coupling.

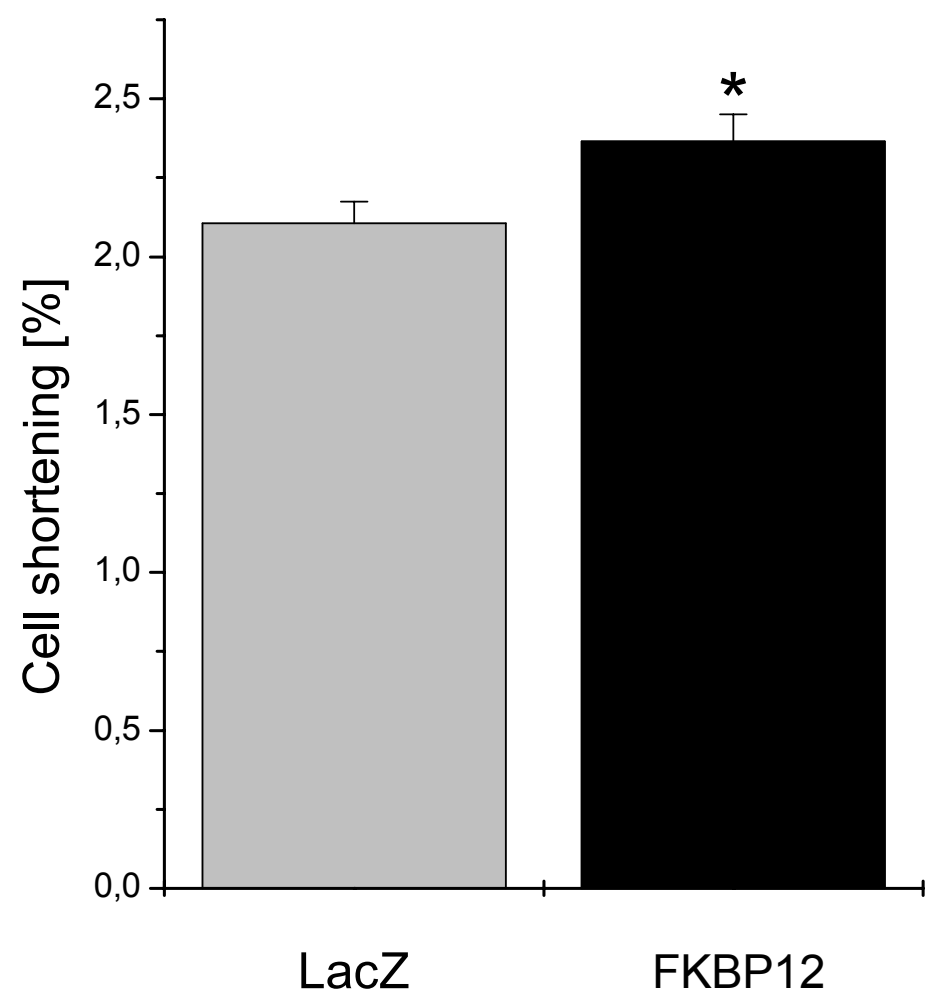

Fig. 12. Statistical analysis of cell shortening in Ad-LacZ and Ad-FKBP12 infected myocytes measured 48 hours post transfection. Cell shortening, expressed in percentage of diastolic cell length, was $14 \%$ higher in Ad-FKBP12 infected cells compared to cells infected with Ad-LacZ $\left(2.4 \pm 0.3 \%\right.$ vs. $2.1 \pm 0.2 \%$, respectively, $\left.{ }^{*} p<0.05\right)$. Values are means \pm sem of 12 independent experiments. Each experiment is based on a different isolation of cardiomyocytes. The mean obtained for one experiment, averages assessments of 10-15 cells. Data were analyzed by Student's $t$-test for paired values.

\subsection{Interaction studies}

Contractility measurements provide physiological evidence that FKBP12 may play a role in cardiac E-C coupling as seen before with FKBP12.6. Interaction studies, using such strategies as co-immunoprecipitation and GST fusion protein pulldown assay, were conducted to provide insight into the molecular mechanisms underlying this effect. Despite previous evidence suggesting a lack of FKBP12 binding to cardiac RyR, we hypothesized that FKBP12 binding to RyR2 does occur, basing on physiological experiments described in 4.2 . 


\subsubsection{FKB12.6 but not FKBP12 co-immunoprecipitates with rabbit cardiac ryanodine receptor}

To examine whether only FKBP12.6 or both FKBP isoforms associate with RyR2, co-immunoprecipitation technique was utilized.

As a starting material for co-immunoprecipitation, CHAPS-solubilized cardiac membrane fraction (CSMF) was used. This preparation is optimal for this type of analysis, since the CSMF is relatively easy to obtain and it is enriched with proteins of sarcoplasmic reticulum, including ryanodine receptor.

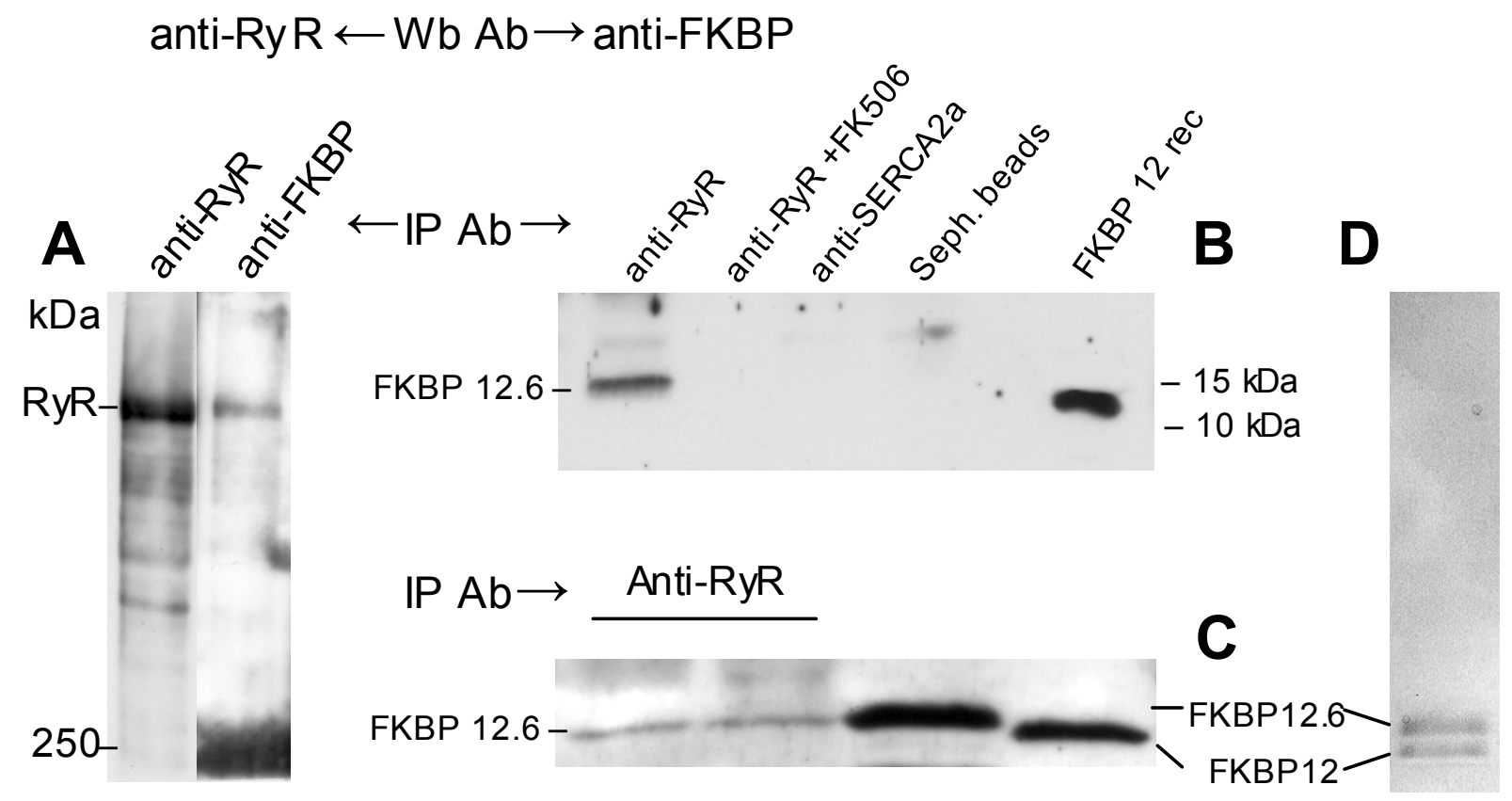

Figure 13. Association of FKBP12.6 with RyR2 in rabbit CHAPS-solubilized cardiac membrane fraction and rabbit cardiomyocytes. $\mathbf{A}$ and $\mathbf{B}-$ The CHAPS-solubilized membrane fraction from rabbit heart was subjected to immunoprecipitation with anti-RyR or anti-FKBP Ab, the immunoprecipitates were electrophoretically separated on $5 \%$ (A) and $15 \%$ (B) SDS-PAAG; detection of RyR or FKBP bands was conducted by Western blot analysis with anti-RyR or anti-FKBP Ab. C - Protein lysates obtained from rabbit cardiomyocytes were subjected to immunoprecipitation with anti-RyR $A b$, the immunoprecipitates were electrophoretically separated on 4-20\% linear gradient SDS-PAAG followed by detection with anti-FKBP Ab. Recombinant FKBP12 and FKBP12.6 display evident difference in their electrophoretic mobilities (C-two last lanes and D), confirming that the resolution capacities of the used 15\% (B and D) and 4-20\% linear gradient (C) SDS-PAAGs are high enough to separate different isoforms of FKBP.

RyR2 was immunoprecipitated from CHAPS-solubilized cardiac membrane fraction (Fig. 13A, lane 1) using a mouse monoclonal anti-RyR antibody (34C clone, Affinity Bioreagents) and its presence in the immunoprecipitate was examined by Western blot analysis using another mouse monoclonal anti-RyR antibody (C3-33 clone, Affinity 
Bioreagents). Different antibodies were used for immunoprecipitation and immunovisualization of RyR2 to increase the reliability of specific detection of RyR.

To examine the presence of FKBP isoforms (both or one of them), the same immunoprecipitate was blotted with anti-FKBP12 antibody (SA-169), which cross-reacts with rabbit FKBP12.6. SA-169 was used rather than the commercially available anti-FKBP12 antibody C-19 because SA-169 appeared to be more sensitive to rabbit antigen. Although this antibody does not discriminate between FKBP12 and FKBP12.6 isoforms, it is still possible to distinguish the two FKBPs on the basis of their electrophoretic mobilities, since FKBP12.6 migrates somewhat slower than FKBP12 (Fig. 13D). After blotting the same immunoprecipitate with SA-169 antibody, only one band appears (Fig. 13B, lane 1). Its electrophoretic mobility is distinctly different from that of recombinant FKBP12 (Fig.13B, lane 5), which was loaded to ensure that the resolution capacity of the gel is high enough to separate the FKBP isoforms. Next to the immunoprecipitates, $12 \mathrm{ng}$ of both recombinant FKBP isoforms ran next to each other, displaying an evident difference in their electrophoretic mobilities and confirming that the two co-immunoprecipitated proteins are FKBP12.6 (Fig. 13C, lanes 1-2). To confirm the specificity of interaction between RyR and FKBP, several negative controls were included: treatment of CHAPS solubilized cardiac membrane fraction with FK506 prior to immunoprecipitation completely abolished RyR2-FKBP12.6 interaction (Fig. 13B, lane 2); incubation of samples with antibody against SERCA2a, which is known neither to be associated with RyR nor with FKBP12, did not lead to precipitation of FKBP12.6 (Fig. 13B, lane 3); incubation of samples with protein G-sepharose beads alone also did not lead to precipitation of FKBP12.6 (Fig. 13B, lane 4).

Reciprocal co-immunoprecipitation using anti-FKBP antibody (C-19) revealed the presence of RyR in the immunoprecipitate (Fig. 13A, lane 2).

Thus, in rabbit, RyR2 co-immunoprecipitates with the FKBP12.6 isoform solely, which is consistent with the previous data obtained for dog, human and rat. However, in view of the physiological evidence of a possible alteration of RyR by FKBP12, we did not reject the hypothesis that FKBP12 may also be associated with RyR2, but concluded from the co-immunoprecipitation data, that when FKBP12 does interact with RyR, the manner of this interaction is different from that of FKBP12.6. It can be of a lower affinity compared to FKBP12.6-RyR2 interaction or the interaction can be transient, which would explain the reason why FKBP12 was not detected by co-immunoprecipitation. Therefore, a second technique, GST fusion protein pulldown assay, was utilized. 


\subsubsection{GST fusion protein pulldown assay}

In order to investigate the interaction between FKBP isoforms and cardiac RyR, GST pulldown assay was implemented, the principle of which is described in Methods (3.5.3). In co-immunoprecipitation, the native associations between proteins should be preserved during the solubilization procedure, which does not always work. In contrast, in GST pulldown assay, a probe protein fused to GST is incubated with the sample containing the potential binding partner after solubilization. This feature of the GST pulldown assay makes it more advantageous for our purpose compared to co-immunoprecipitation.

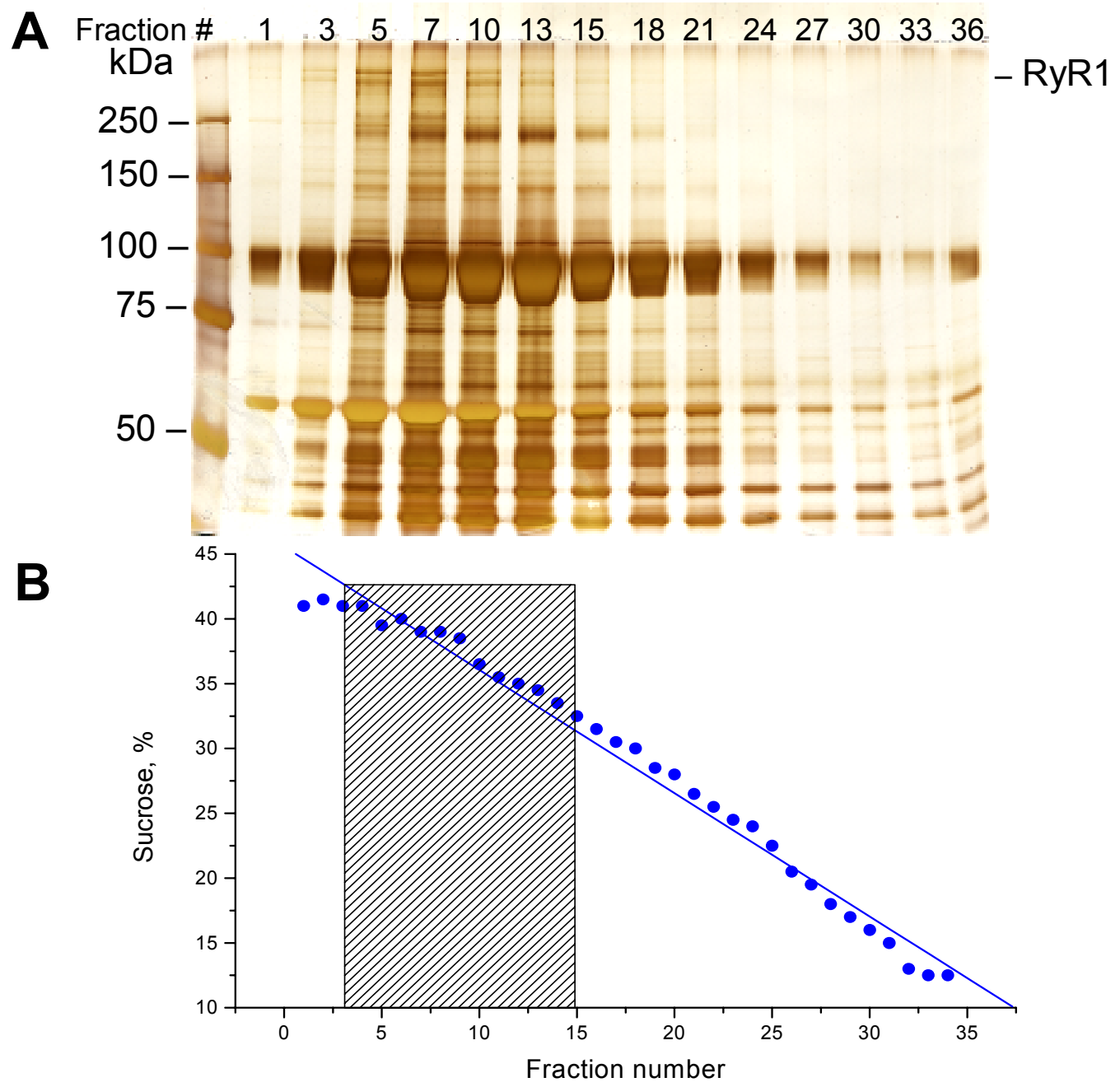

Figure 14. Fractionation of skeletal muscle SR on a $15-45 \%$ linear sucrose gradient. (A) To show the protein profile of fractionated crude SR, $5 \mu$ laliquots from every other fraction were electrophoretically separated on $7.5 \%$ SDS-PAAG followed by silver staining. Heavy SR enriched with ryanodine receptor was recovered at approximately $32-42 \%$ sucrose (fractions 3-15) (B).

To confirm a supposed interaction by GST fusion protein pulldown assay, the target protein (RyR2) must be present in sufficient quantities to allow the interaction to be visualized with the chosen method of detection. Therefore, for the first pulldown trials, it 
was decided to use RyR-enriched fractions as a source of RyR to ensure the abundance of the analyzed target protein. In the experiment, both FKBP isoforms were probed for their interactions with RyR2. To verify the binding properties of FKBP12, its interaction with RyR1 was examined, since this interaction does not raise any doubts, similar to that between FKBP12.6 and RyR2. Therefore both RyR1 and RyR2 were isolated. Rabbit skeletal muscle served as the source of RyR1. Since ryanodine receptor preparation necessitates considerable amount of starting material (100 g for the preparation described here), RyR2 was isolated from human heart.

\subsubsection{Isolation and identification of RyR1 and RyR2}

RyR1 and RyR2 were isolated by sucrose density gradient centrifugation. Figure 14 represents one of the crucial steps of the procedure: fractionation of crude SR by sucrose density linear gradient centrifugation, in the course of which heavy SR enriched with ryanodine receptor was recovered. Obtained heavy SR vesicles were solubilized with CHAPS and subjected to a second sucrose density gradient centrifugation, which yielded RyR-enriched fractions of reasonable purity (Fig. 15A, B). In the given example of RyR preparation (Fig. 15B), the isolated RyR1 revealed to be present as two bands (Fig. 15B, lanes 6-7); the lower one represents a proteolytic breakdown product, which, as was reported in literature, is frequently obtained during isolation procedure.

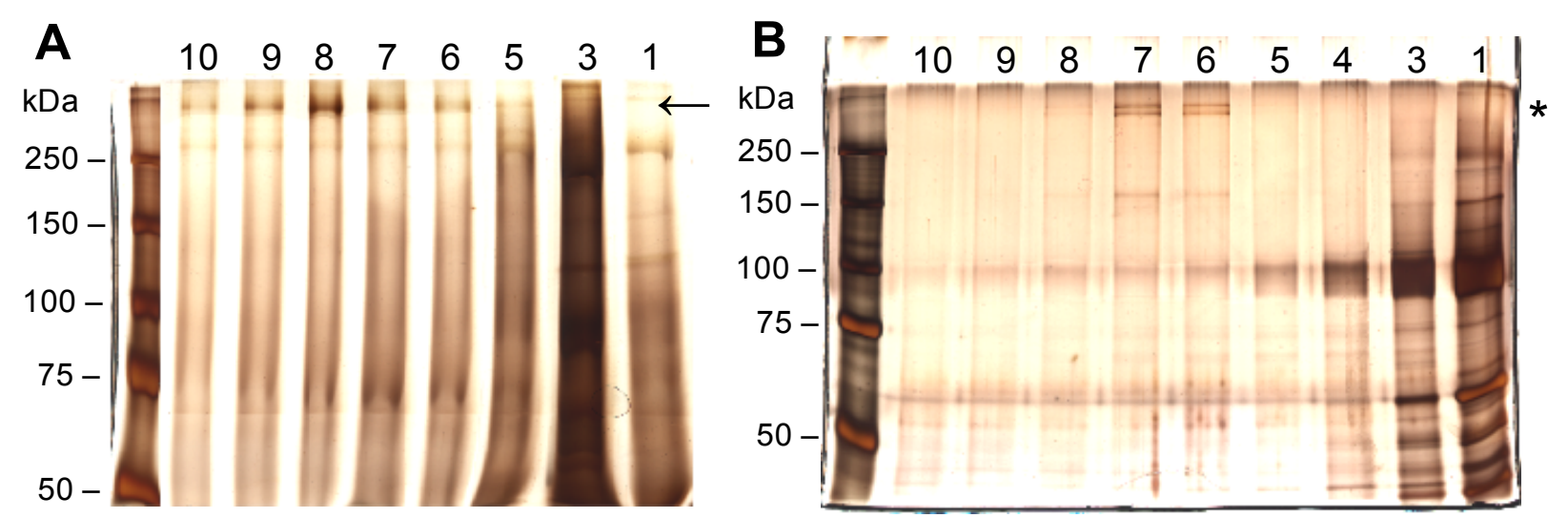

Figure 15. Fractionation of cardiac (A) and skeletal muscle (B) CHAPS-solubilized heavy SR on a $\mathbf{1 0 - 2 8 \%}$ linear sucrose gradient. $10 \mu \mathrm{l}$ aliquots from collected fractions were electrophoretically separated on $7.5 \%$ SDS-PAAG followed by silver staining. The major high molecular weight bands, appearing in fractions 7-9 (A) and 6-7 (B) are RyR2 $(\leftarrow)$ and RyR1 $\left(^{*}\right)$, respectively.

Since the procedure of RyR isolation has not been utilized before in our laboratory, it was suggested to confirm that the obtained high molecular weight proteins are really RyR1 and RyR2 using MALDI-TOF mass spectrometry. Both proteins were identified as rabbit skeletal muscle RyR1 (Fig. 16) and human cardiac RyR2 (Fig. 17). 


\section{Protein View}

Match to: gi|134134; Score: 157

Ryanodine receptor 1 (Skeletal muscle-type ryanodine receptor) Oryctolagus cuniculus

Nominal mass $(\mathrm{Mr})$ : 564892; Calculated pI value: 5.16

Number of mass values matched: 25

Sequence Coverage: $4 \%$

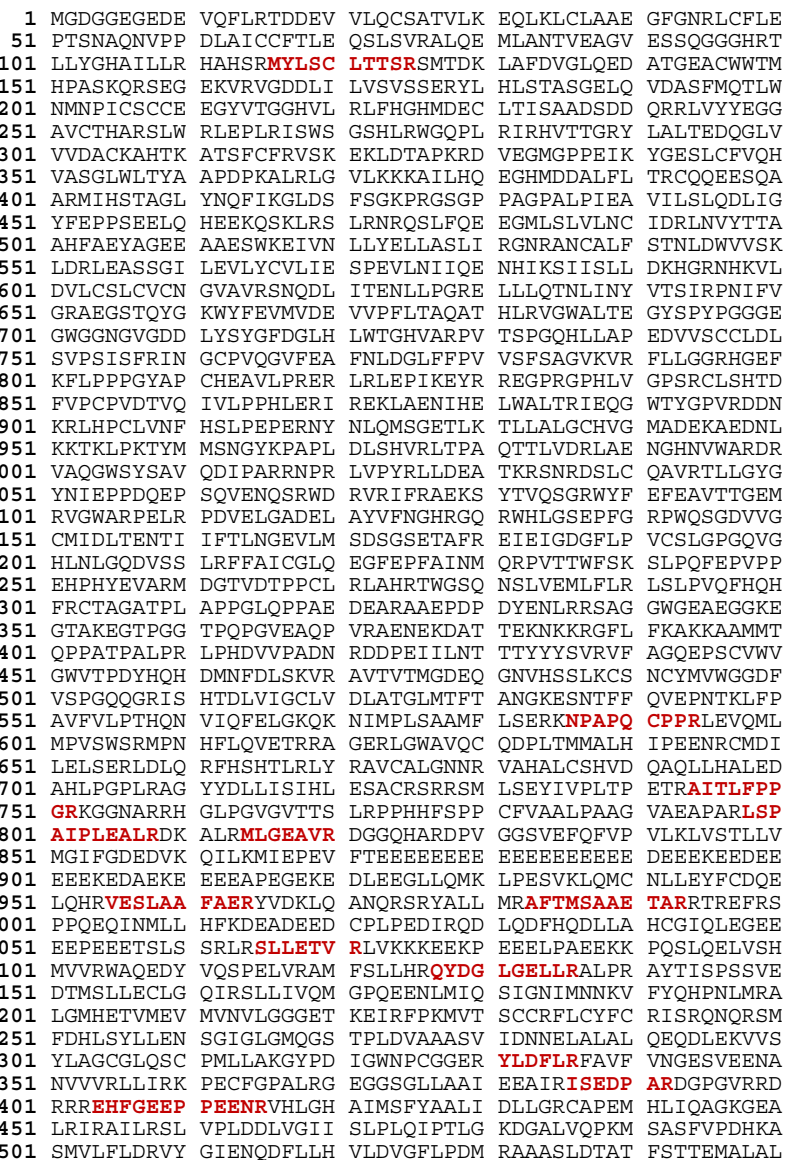

2551 NRYLCLAVLP LITKCAPLFA GTEHRAIMVD SMLHTVYRLS RGRSLTKAQR 2601 DVIEDCLMAL CRYIRPSMLQ HLLRRLVFDV PILNEFAKMP LKLLTNHYER 2651 CWKYYCLPTG WANFGVTSEE ELHLTRKLFW GIFDSLAHKK YDQELYRMAM 2701 PCLCAIAGAL PPDYVDASYS SKAEKKATVD AEGNFDPRPV ETLNVIIPEK 2751 LDSFINKFAE YTHEKWAFDK IQNNWSYGEN VDEELKTHPM LRPYKTFSEK 2801 DKEIYRWPIK ESLKAMIAWE WTIEKAREGE EERTEKKKTR KISQTAQTYD 2851 PREGYNPQPP DLSGVTLSRE LQAMAEQLAE NYHNTWGRKK KQELEAKGGG 2901 THPLLVPYDT LTAKEKARDR EKAQELLKFL QMNGYAVTRG LKDMELDTSS 2951 IEKRFAFGFL QQLLRWMDIS QEFIAHLEAV VSSGRVEKSP HEQEIKFFAK 3001 ILLPLINQYF TNHCLYFLST PAKVLGSGGH ASNKEKEMIT SLFCKLAALV 3051 RHRVSLFGTD APAVVNCLHI LARSLDARTV MKSGPEIVKA GLRSFFESAS 3101 EDIEKMVENL RLGKVSQART QVKGVGQNLT YTTVALLPVL TTLFQHIAQH 3151 QFGDDVILDD VQVSCYRTLC SIYSLGTTKN TYVEKLRPAL GECLARLAAA 3201 MPVAFLEPQL NEYNACSVYT TKSPRERAIL GLPNSVEEMC PDIPVLDRLM 3251 ADIGGLAESG ARYTEMPHVI EITLPMLCSY LPRWWERGPE APPPALPAGA 3301 PPPCTAVTSD HLNSLLGNIL RIIVNNLGID EATWMKRLAV FAQPIVSRAR 3351 PELLHSHFIP TIGRLRKRAG KVVAEEEQLR LEAKAEAEEG ELLVRDEFSV 3401 LCRDLYALYP LLIRYVDNNR AHWLTEPNAN AEELFRMVGE IFIYWSKSHN 3451 FKREEQNFVV QNEINNMSFL TADSKSKMAK AGDAQSGGSD QERTKKKRRG 3501 DRYSVQTSLI VATLKKMLPI GLNMCAPTDQ DLIMLAKTRY ALKDTDEEVR 3551 EFLQNNLHLQ GKVEGSPSLR WQMALYRGLP GREEDADDPE KIVRRVQEVS 3601 AVLYHLEQTE HPYKSKKAVW HKLLSKQRRR AVVACFRMTP LYNLPTHRAC 3651 NMFLESYKAA WILTEDHSFE DRMIDDLSKA GEQEEEEEEV EEKKPDPLHQ 3701 LVLHFRTAL TEKSKLDEDY LYMAYADIMA KSCHLEEGGE NGEAEEEEVE 3751 VSFEEKEMEK QRLLYQQSRL HTRGAAEMVL QMISACKGET GAMVSSTLKL 3801 GISILNGGNA EVQQKMLDYL KDKKEVGFFQ SIQALMQTCS VLDLNAFERQ 3901 NYIRTQTGNT TTINIIICTV DYITRLOESI SDFYWYYSGK DVIFEOGRN 3901 NYLRTQTGN TTINIIICTV DYLLRLQESI SDFYYYSGK DVIEEQGKR 3951 FSKAMSVAKQ VFNSLTEYIQ GPCHNDL AHSLWAMV GFLHVAHMM 4001 MKLADSSQ 4051 SSSN EMILK FFDFLKLKD IVGSEAFQDY VIDPRGLISK KDFQKAMDSQ 4101 KQFTGPEIQF LLSCSEADEN EMINFEAN RFQEPARDIG FNVAVLTNL 4151 SEATMR RN 4201 NRAQWEMPQV KESKRQFIFD VVNEGGEAEK MELFVSTCED TIFEMQIAAQ 4251 ISEPEGEPEA DEDEGMGEAA AEGAEEGAAG AEGAAGTVAA GATARLAAAA 4351 ARART 431 AGALRLLWGS LFGGLUEGA KKVIVTELLA GMPDPTSDEV HGEQPAGPG 441 DADGAGEG

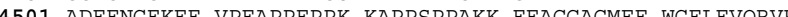
4551 4551 FLNYLSRNFY TLRFLALFLA FAINFILLFY KVSDSPPGED DMEGSAAGDL 4651 TLVAFLCTIG YNCLKVDLVI FKREKELARK IEFDGLYTE OPGDDVKGQ 4701 WDRIVINTPS FPSNYWDKFV KRKVIDURK 4751 TAHNRKPD PRGLITWLMS IDVKYQIWKF GVIETDNSFI YLGWMVMSL

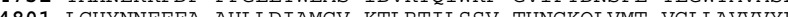

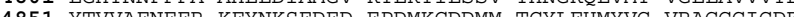
4901 T. 4051 IEDARE 5001 TEHTGOESYV WKMYOERCWD FFPAGDCFRK OYEDOLS

Matched peptides shown in Bold Red

Figure 16. Extract from Mascot Search Results. The high molecular weight band obtained in the course of RyR1 isolation was subjected to in-gel trypsin digestion followed by MALDI-TOF mass spectrometry. Analyzed protein showed a perfect match with rabbit RyR1: matched peptides shown in Bold Red are distributed evenly over the entire sequence of this huge protein of more than 5000 amino acids per protomer. 


\title{
Protein View
}

Match to: gi|4506757; Score: 181

ryanodine receptor 2 [Homo sapiens]

\author{
Nominal mass $(\mathrm{Mr})$ : 569269; Calculated pI value: 5.74 \\ Number of mass values matched: 35 \\ Sequence Coverage: $6 \%$
}

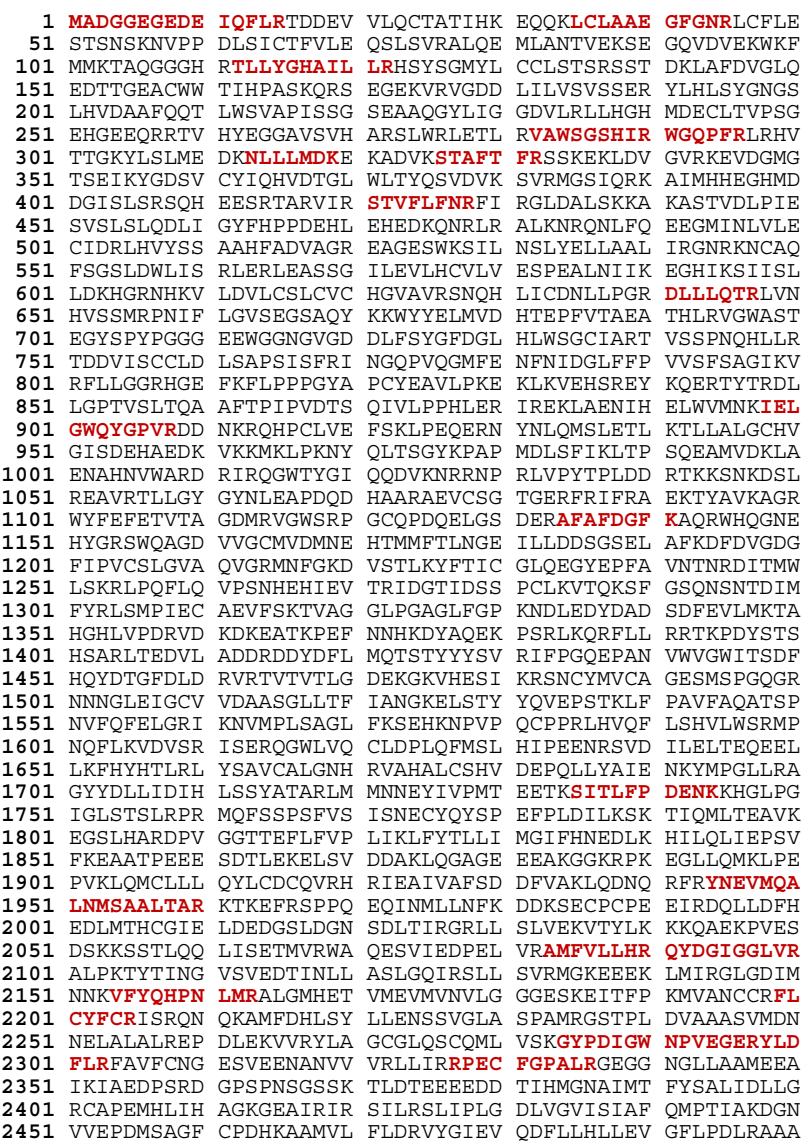

2501 SLDTAALSAT DMALALNRYL CTAVLPLLTR CAPLFAGTEH HASLIDSLLH 2551 TVYRLSKGCS LTKAQRDSIE VCLLSICGQL RPSMMQHLLR RLVFDVPLLN 2601 EHAKMPLKLL TNHYERCWKY YCLPGGWGNF GAASEEELHL SRKLFWGIFD 2651 ALSQKKYEQE LFKLALPCLS AVAGALPPDY MESNYVSMME KQSSMDSEGN 2701 FNPQPVDTSN ITIPEKLEYF INKYAEHSHD KWSMDKLANG WIYGEIYSDS 2751 SKVQPLMKPY KLLSEKEKEI YRWPIKESLK TMLARTMRTE RTREGDSMAL 2801 YNRTRRISQT SQVSVDAAHG YSPRAIDMSN VTLSRDLHAM AEMMAENYHN 2851 IWAKKKKMEL ESKGGGNHPL LVPYDTLTAK EKAKDREKAQ DILKFLQING 2901 YAVSRGFKDL ELDTPSIEKR FAYSFLQQLI RYVDEAHQYI LEFDGGSRGK 2951 GEHFPYEQEI KFFAKVVLPL IDQYFKNHRL YFLSAASRPL CSGGHASNKE 3001 KEMVTSLFCK LGVLVRHRIS LFGNDATSIV NCLHILGQTL DARTVMKTGL 3051 ESVKSALRAF LDNAAEDLEK TMENLKQGQF THTRNQPKGV TQIINYTTVA 3101 LLPMLSSLFE HIGQHQFGED LILEDVQVSC YRILTSLYAL GTSKSIYVER 3151 QRSALGECLA AFAGAFPVAF LETHLDKHNI YSIYNTKSSR ERAALSLPTN 3201 VEDVCPNIPS LEKLMEEIVE LAESGIRYTQ MPHVMEVILP MLCSYMSRWW 3251 EHGPENNPER AEMCCTALNS EHMNTLLGNI LKIIYNNLGI DEGAWMKRLA 3301 VFSQPIINKV KPQLLKTHFL PLMEKLKKKA ATVVSEEDHL KAEARGDMSE 3351 AELLILDEF T TLARDLYAFY PLLIRFVDYN RAKWLKEPNP EAEELFRMVA 3401 EVFIYWSKSH NFKREEQNFV VQNEINNMSF LITDTKSKMS KAAVSDQERK 3451 KMKRKGDRYS MQTSLIVAAL KRLLPIGLNI CAPGDQELIA LAKNRFSLKD 3501 TEDEVRDIIR SNIHLQGKLE DPAIRWQMAL YKDLPNRTDD TSDPEKTVER 3551 VLDIANVLFH LEQKSKRVGR RHYCLVEHPQ RSKKAVWHKL LSKQRKRAVV 3601 ACFRMAPLYN LPRHRAVNLF LQGYEKSWIE TEEHYFEDKL IEDLAKPGAE 3751 PPEDEGTR VDPHLLLL FSRALTEKC KLEEDFLYMA YADIMAKSCH 3701 DEEDDDGEEE VKSFEEKEME KQKLLYQQAR LHDRGAAEMV LQTISASKGE 3751 TGPMVAATLK LGIAILNGGN STVQQKMLDY LKEKKDVGFF QSLAGLMQSC 3851 SDLAF R 3851 NSDFQNYLRT QTGNNTINI IISTVDYLLR VQESISDFYW YYSGKDVIDE 3901 QGQRNFSKAI QVAKQVFNTL TEYIQGPCTG NQQSLAHSRL WDAVVGFLHV OT1 4001 DMLVESSNN EMILKFDMF LKLKDLTSSD TFKEYDPDGK GVISKRDFHK 4051 AMESHKHYTQ SETEFLLSCA ETDENETLDY EEFVKRFAP AKDIGFNVA (101 LLTNLSEHP NDTRLQTHE LAESVLNYT PFLRIEIMG SAKRIERVY 411 LISESSROW EKPQVKSR 4201 QLAAQISESD LNERSANKEE SEKERPEEQG PRMAFFSILT VRSALFALRY

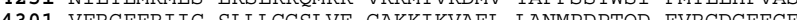
4301 VRRGFRIIC SLLLGGSLVE GAKKIKVAEL LANMPDPTQD EVRGDGEEG 4351 RKPLEAALPS EDLTDLKELT EESDLLSDIF GLDLKREGGQ YKLIPHNPNA 4451 EKAKEDKGKO KLRQI HTHRY GEDEVDESAF WKKITAYQQK LLVYEARNFY 4451 TKAKENG 4501 NMRMLALFVA FAINFLLLY KVSTS 4601 KREKEVARKI REDGTYITEQ PSEDDIKGOW DRLVINTQSE PINYWDKFVK 4601 KREKEVAR 4701 IDVKYQMUKI GVVFTDNSFI YLAWYMTMSV LGHYMNTFEFA AHLIDIAMGE 4751 KTLRTILSSV THNGKOLVLT VGLTAVVVY YTVVA FNFFR KFYNYSEDGD (3)1 4801 PDMKCDN TCYMT 4901 VDHGFETHTL QEHT 4951 FFPAGDCFRK OYEDOLN

Matched peptides shown in Bold Red

Figure 17. Extract from Mascot Search Results. The high molecular weight band obtained in the course of RyR2 isolation was subjected to in-gel trypsin digestion followed by MALDI-TOF mass spectrometry. Analyzed protein showed a perfect match with human RyR2: matched peptides shown in Bold Red are distributed evenly over the entire sequence of this huge protein of around 5000 amino acids per protomer. 


\subsubsection{Expression and purification of GST-FKBP12 and GST-FKBP12.6 fusion proteins}

The recombinant GST fusion proteins, necessary components of GST pulldown assay, were expressed and purified as described in Methods (3.5.2). Figure 18A shows the time course of GST-FKBP12 and GST-FKBP12.6 overexpression in transfected BL-21 $E$ coli. Figures 18B, C show the purification of GST-FKBP12. The procedure gives a pure product with high yield, averaging 6-7 $\mathrm{mg}$ of the protein per preparation. One should note that the molecular weight of GST fusion proteins is shifted up to $38 \mathrm{kDa}$ due to the $26 \mathrm{kDa}$ glutathione S-transferase tag, but even tagged FKBP12 and FKBP12.6 display an evident difference in their electrophoretic mobilities just as the native isoforms (Fig. 19A, B).

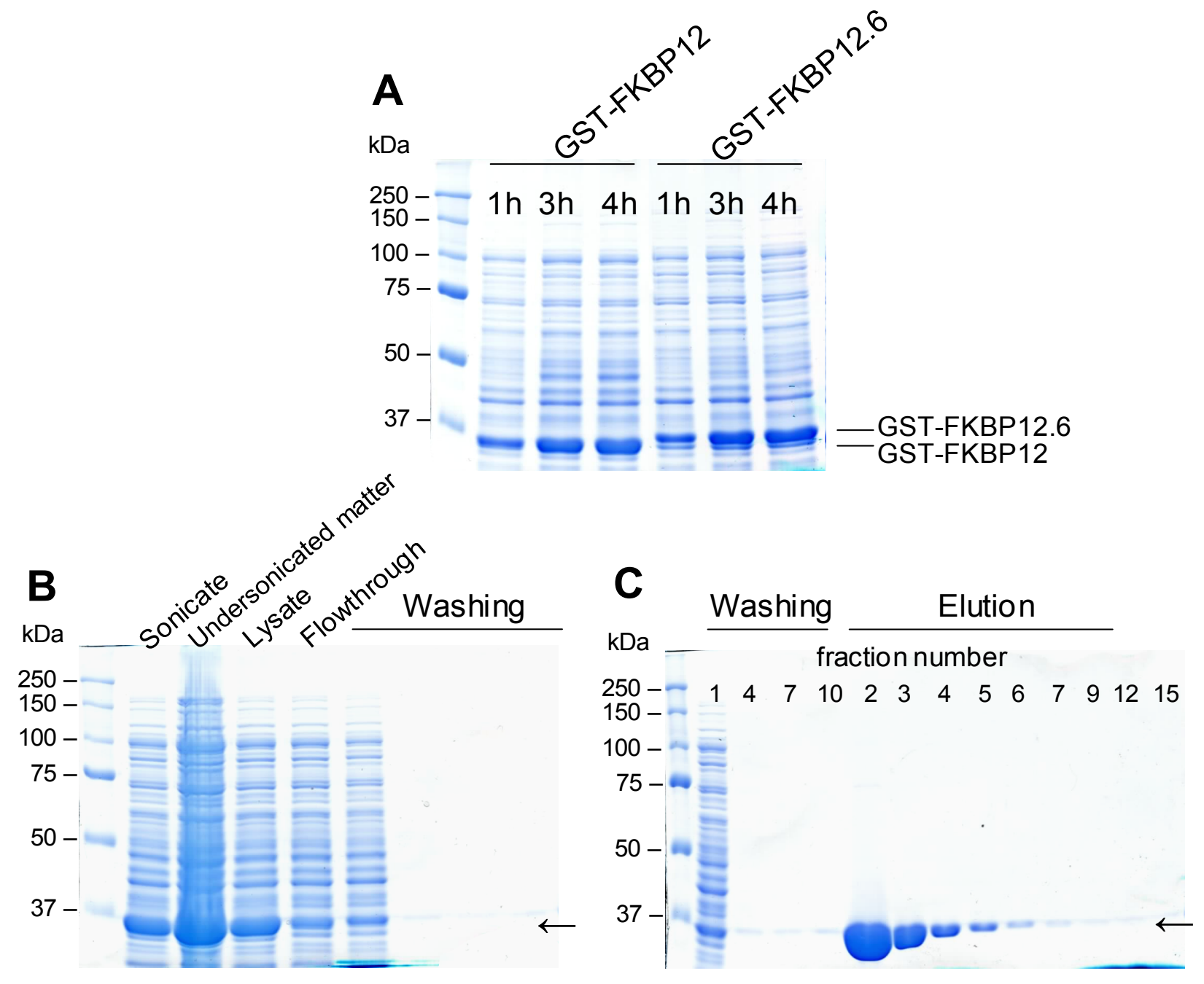

Figure 18. Coomassie Blue-stained $7.5 \%$ gels depicting different stages of GST fusion proteins expression and purification. $20 \mu \mathrm{l}$ aliquots from different fractions obtained in the course of the procedure were analyzed. (A) Bacterial growth and induction: GST-FKBPs are expressed in time dependent manner in BL-21 E.coli. (B) Derived fractions obtained in the course of bacterial lysate preparation and loading of the latter one onto glutathione-sepharose GSTrap $1 \mathrm{ml}$ column. (C) Elution profile of GST-FKBP12, which elutes from the column as a very sharp peak (fractions 2-4). The arrow indicates position of GST-FKBP12. 

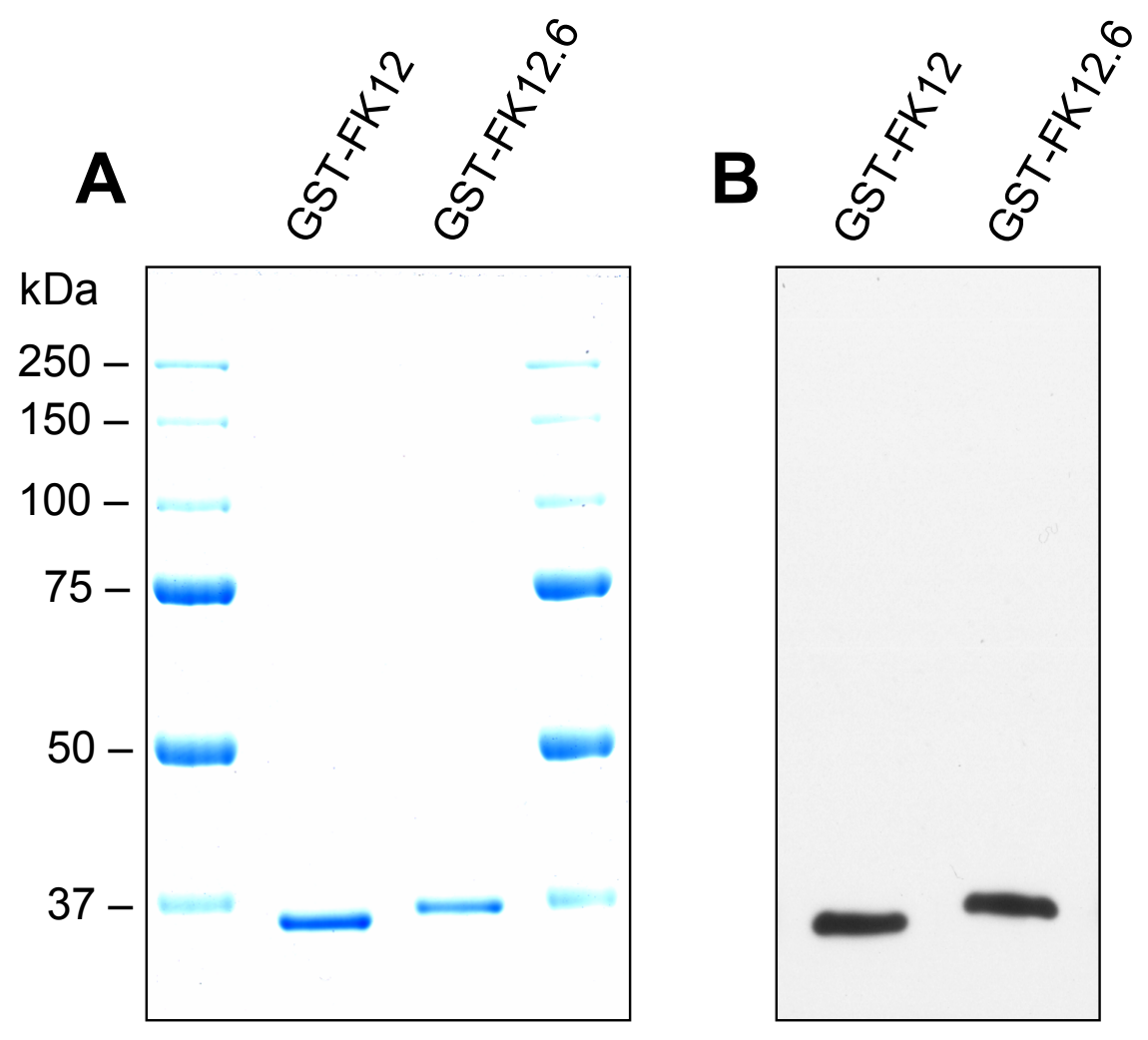

Figure 19. Coomassie Blue-stained gel (A) and Western blot (B) showing different electrophoretic mobilities of GST-FKBP12 and GST-FKBP12.6 recombinant proteins. 2 $\mu \mathrm{g}$ and $100 \mathrm{ng}$ of each were subjected to SDS-PAGE on $10 \%$ gels, followed by Coomassie staining (A) and Western blot with anti-GST antibody (B), respectively.

\subsubsection{Probing of isolated human cardiac RyR2 and rabbit skeletal muscle RyR1 and detection of FKBP-RyR interaction}

For a start, isolated RyR2 and RyR1 were probed with GST-FKBP12.6 and GST-FKBP12. RyR2 was precipitated based on its specific association with FKBP12.6 and RyR1 was precipitated based on its specific association with FKBP12 (Fig. 20A, B). The retained RyR2 and RyR1 were specifically bound to GST-FKBP proteins since the interaction of RyR1-FKBP12 and RyR2-FKBP12.6 was completely disrupted upon addition of FK506 $(60 \mu \mathrm{M})$. This data supports the earlier observation that RyR1 and FKBP12 as well as RyR2 and FKBP12.6 can tightly associate with each other. Next, the reciprocal experiment was performed, where GST-FKBP12 was incubated with RyR2 and GST-FKBP12.6 with RyR1, revealing that GST-FKBP12 is able to pull down cardiac RyR as well as GST-FKBP12.6 being able to pull down skeletal muscle RyR (Fig. 21A, B). 


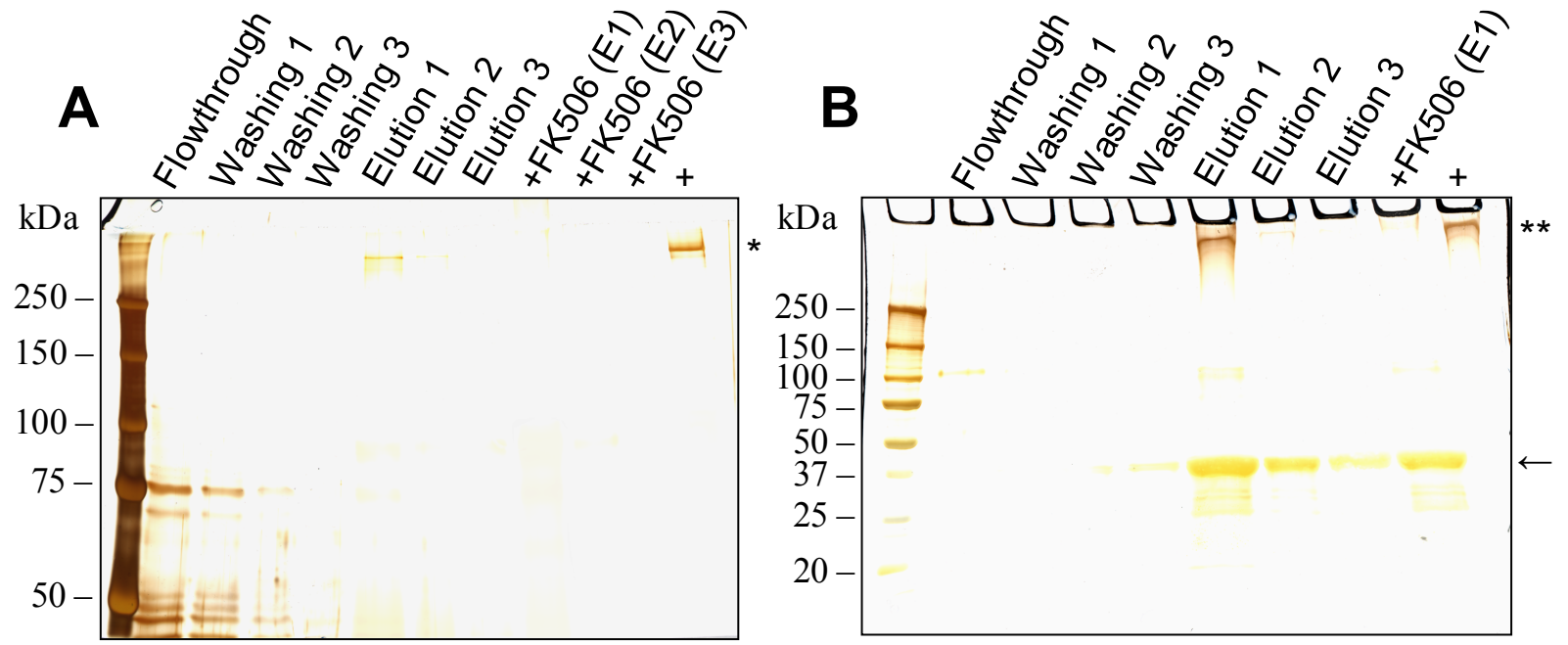

Figure 20. Affinity precipitation of RyR2 (A) and RyR1 (B) based on their specific associations with FKBP12.6 and FKBP12, respectively. Isolated RyR2 and RyR1 were incubated with GST-FKBP12.6 and GST-FKBP12, respectively, and formed complexes were immobilized on glutathione-sepharose 4B. The retained proteins were eluted with $10 \mathrm{mM}$ reduced glutathione and subjected to SDS-PAGE (on $7.5 \%$ gel for RyR2 and $4-20 \%$ linear gradient gel for RyR1), followed by silver staining. Aliquots from different fractions were analyzed: flowthrough - supernatant fraction obtained after adsorption of RyR-GST-FKBP complex by glutathione-sepharose $4 \mathrm{~B}$; washing 1-3 - fractions containing proteins which were nonspecifically bound to the matrix; elution 1-3-fractions containing proteins specifically bound to the immobilized GST-FKBPs; FK506 control - fractions containing proteins bound to immobilized GST-FKBPs in the presence of $60 \mu \mathrm{M}$ FK506. The symbols in the right margin of the images are as follows: asterisk indicates RyR2, double asterisk - RyR1 and arrow - GSTFKBP12.

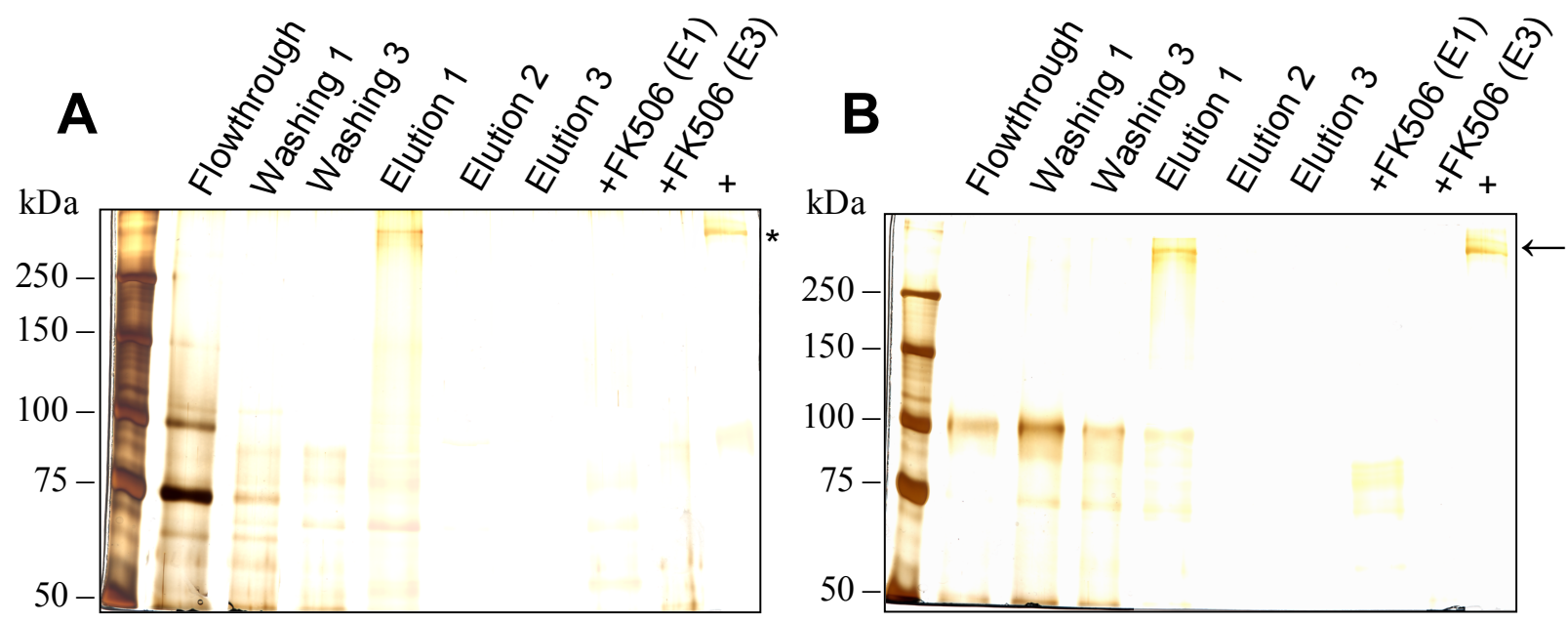

Figure 21. Affinity precipitation of RyR2 (A) and RyR1 (B) based on their specific associations with FKBP12 and FKBP12.6, respectively. Isolated RyR2 and RyR1 were incubated with GST-FKBP12 and GST-FKBP12.6, respectively, and formed complexes were immobilized on glutathione-sepharose 4B. The retained proteins were eluted with $10 \mathrm{mM}$ reduced glutathione and subjected to SDS-PAGE on $7.5 \%$ gels, followed by silver staining. Aliquots from different fractions were analyzed: flowthrough - supernatant fraction obtained after adsorption of RyR-GST-FKBP complex by glutathione-sepharose 4B; washing 1-3fractions containing proteins nonspecifically bound to the matrix; elution 1-3-fractions containing proteins specifically bound to immobilized GST-FKBPs; FK506 control - fractions containing proteins bound to immobilized GST-FKBPs in the presence of $60 \mu \mathrm{M}$ FK506. The symbols in the right margine of images are as follows: asterisk indicates RyR2, arrow - RyR1. 


\subsubsection{Probing of samples containing rabbit cardiac RyR, detection of interacting proteins and identification of RyR}

Once optimal conditions of the pulldown assay, at which binding between the target protein (isolated human RyR2) and ligand (both FKBP isoforms) occurs, were established, the same protocol was applied to rabbit cardiac material utilizing a more straightforward approach to prepare the target protein, the source of which in this case were solubilized proteins of whole homogenate, prepared as described in Methods (3.5.3).

The membrane proteins, including $\mathrm{Ca}^{2+}$-release channels were gently solubilized and samples were incubated with either GST-FKBP12.6 or GST-FKBP12. The formed complexes, immobilized on glutathione-sepharose, were washed and then eluted with glutathione in a single elution step, since in previous experiments it was established that the major portion of the fusion protein and virtually all bound RyR appear in the first elution fraction. Since the total protein pool in the given preparation is considerably larger than in the RyR-enriched fractions used previously, it was important to control for the possibility of nonspecific aggregation and to ensure the specificity of the association between the probe protein (FKBP12.6 or FKBP12) and its putative partner (RyR2). For this reason, several negative controls were included. It is, e.g., important to exclude unspecific binding between the putative target protein and GST, therefore, the samples containing target protein were incubated with pure GST at a concentration equivalent to that in the fusion protein. Likewise, incubation with matrix alone was implemented to exclude the possibility of nonspecific adhesion of RyR to glutathione-sepharose. Figure 22 shows the extraction of rabbit RyR2 using GST-FKBP12 and GST-FKBP12.6 immobilized on glutathione-sepharose 4B. RyR2 shown in lanes 3 and 4 (Fig. 22 A) was precipitated on the basis of its association with GST-FKBP12 taken at amounts of $30 \mu \mathrm{g}$ and $100 \mu \mathrm{g}$, respectively. RyR2 shown in lane 5 was precipitated using GST-FKBP12.6 $(30 \mu \mathrm{g})$. Remarkably, both ligands were able to pull down the target protein (RyR2) with similar efficiencies. A 3-fold excess of ligand did not pull down more RyR2, suggesting that the amount of the ligand used in the experiment was saturating. The retained RyR2 was specifically bound to GST-FKBP12, since GST alone did not bind any RyR2 (Fig. 22A, lane 6), nor did matrix alone bind any RyR2 (Fig. 22A, lane 7). From one of the precipitates, formed upon interaction with GST-FKBP12, RyR2 was eluted with 60 $\mu \mathrm{M}$ FK506 (instead of $10 \mathrm{mM}$ glutathione) as a specific competitor. This sample served as an additional control to validate the specificity of interaction. Ethanol, the solvent of FK506, was applied to another identical sample. Elution with FK506 caused the release 
of RyR2 from the formed precipitate (Fig. 22A, lane 8), in contrast to treatment with vehicle alone, confirming the specificity of the interaction. Blotting the same precipitates with anti-RyR antibody revealed that the level of RyR retention is sufficiently high, since no signal was detected in the flowthrough fraction, indicating that the developed system works efficiently and is suitable to purify the ryanodine receptor from small amounts of starting material.

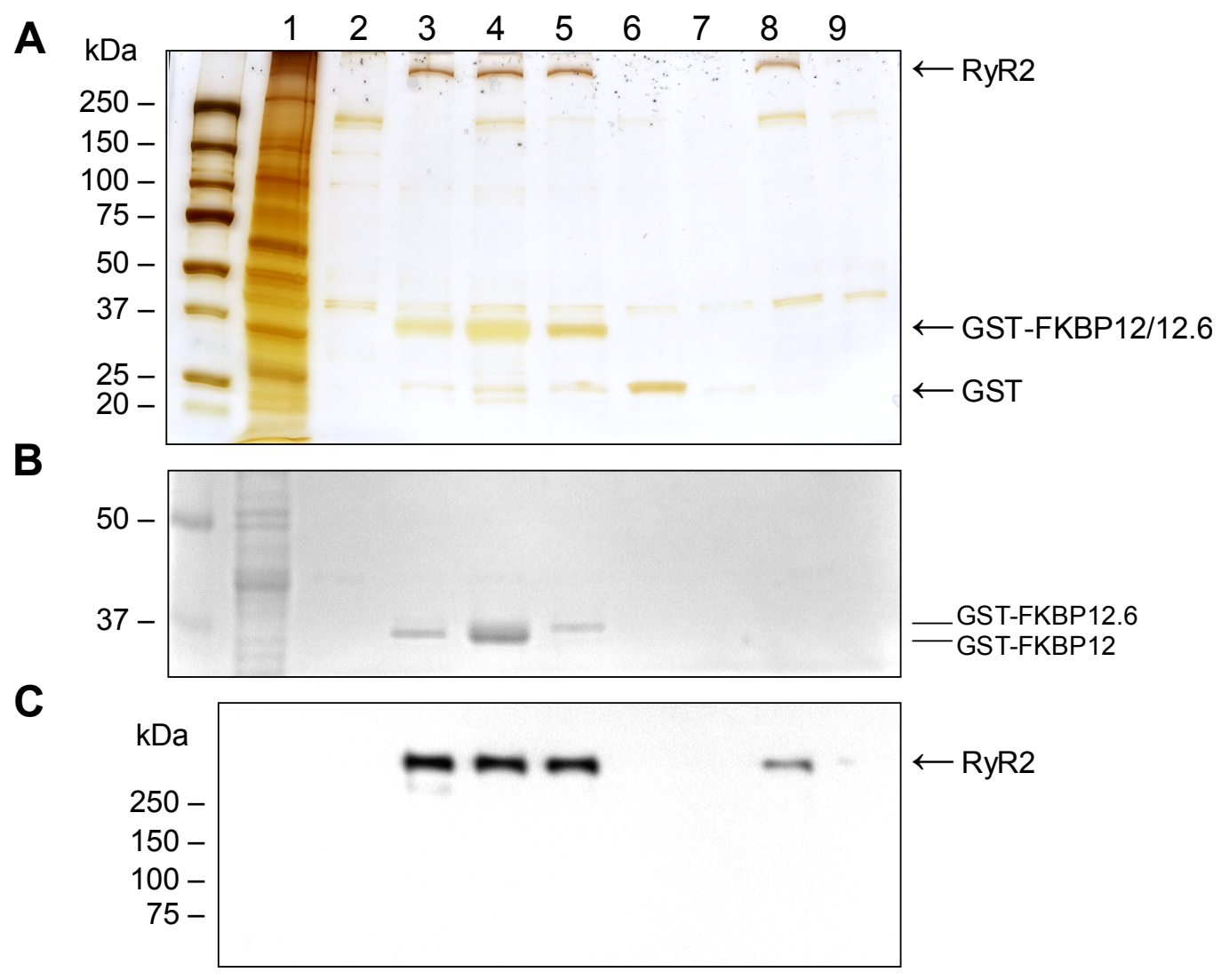

Figure 22. Affinity purification of RyR2 from rabbit cardiomyocyte homogenate using GST-FKBP12 and GST-FKBP12.6. Electrophoresis was carried out on 4-20\% linear gradient (A and C) and 10\% (B) SDS-PAAGs and RyR was detected by silver staining (A) or by Western blot analysis using anti-RyR antibody (C). Lane 1, the supernatant after adsorption of RyR-GST-FKBP12 complex by glutathione-sepharose 4B; lane 2, the supernatant after washing RyR-GST-FKBP12 complex immobilized on glutathione-sepharose; lanes 3-4, RyR2 bound to immobilized GST-FKBP12; lane 5, RyR2 bound to immobilized GST-FKBP12.6; lanes 6 and 7, fractions bound to immobilized GST and glutathione-sepharose, respectively; lanes 8 and 9, fractions eluted from the matrix using $60 \mu \mathrm{M}$ FK506 and vehicle alone, respectively. (B) $10 \%$ SDS-PAAG stained with Coomassie Blue, demonstrating different electrophoretic mobilities of GST-FKBP12 and GST-FKBP12.6. Data shown are representative of more than three similar experiments performed using cellular material from different rabbit hearts.

The approach described here was applied to human crude homogenate to pull down RyR2 and to validate the preliminary data regarding its interaction with FKBP isoforms. As shown in Figure 23 (lane 3), GST-FKBP12 displayed specific, FK506 displaceable 
interaction with RyR2 with an efficiency similar to that of GST-FKBP12.6 (Fig. 23, lane 4).

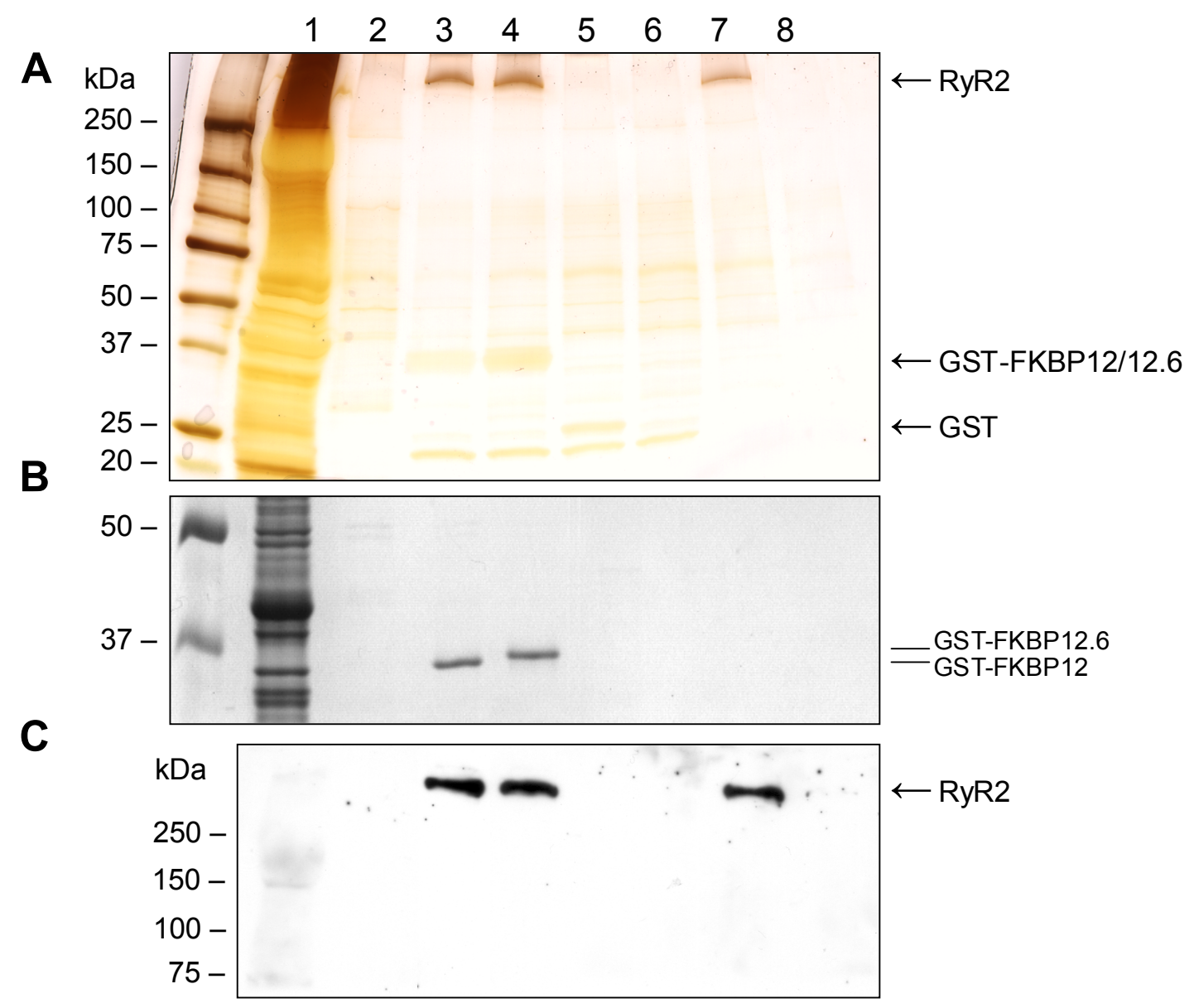

Figure 23. Affinity purification of RyR2 from human cardiac homogenate using GST-FKBP12 and GST-FKBP12.6. Electrophoresis was carried out on 4-20\% linear gradient (A and C) and $10 \%$ (B) SDS-PAAGs and RyR was detected by silver staining (A) or by Western blot analysis using anti-RyR antibody (C). Lane 1, the supernatant after adsorption of RyR-GST-FKBP12 complex by glutathione-sepharose 4B; lane 2, the supernatant after washing RyR-GST-FKBP12 complex immobilized on glutathione-sepharose; lanes 3 and 4, RyR2 bound to immobilized GST-FKBP12 and RyR2 bound to immobilized GST-FKBP12.6, respectively; lanes 5 and 6, fractions bound to immobilized GST and glutathione-sepharose, respectively; lanes 7 and 8, fractions eluted from the matrix using $60 \mu \mathrm{M}$ FK506 and vehicle alone, respectively. (B) 10\% SDS-PAAG stained with Coomassie Blue, demonstrating different electrophoretic mobilities of GST-FKBP12 and GST-FKBP12.6. Data shown are representative of three similar experiments.

To exclude the possibility of detecting RyR1 instead of RyR2 when GST-FKBP12 is used as the ligand, the high molecular weight proteins from each species recognized by anti-RyR antibody and precipitated either with GST-FKBP12 or with GST-FKBP12.6 were subjected to MALDI-TOF mass spectrometry. Both were identified as cardiac isoform of ryanodine receptor (Fig. 24-27).

Thus, these studies provide clear evidence that both rabbit and human RyR2 are capable of binding to FKBP12. 


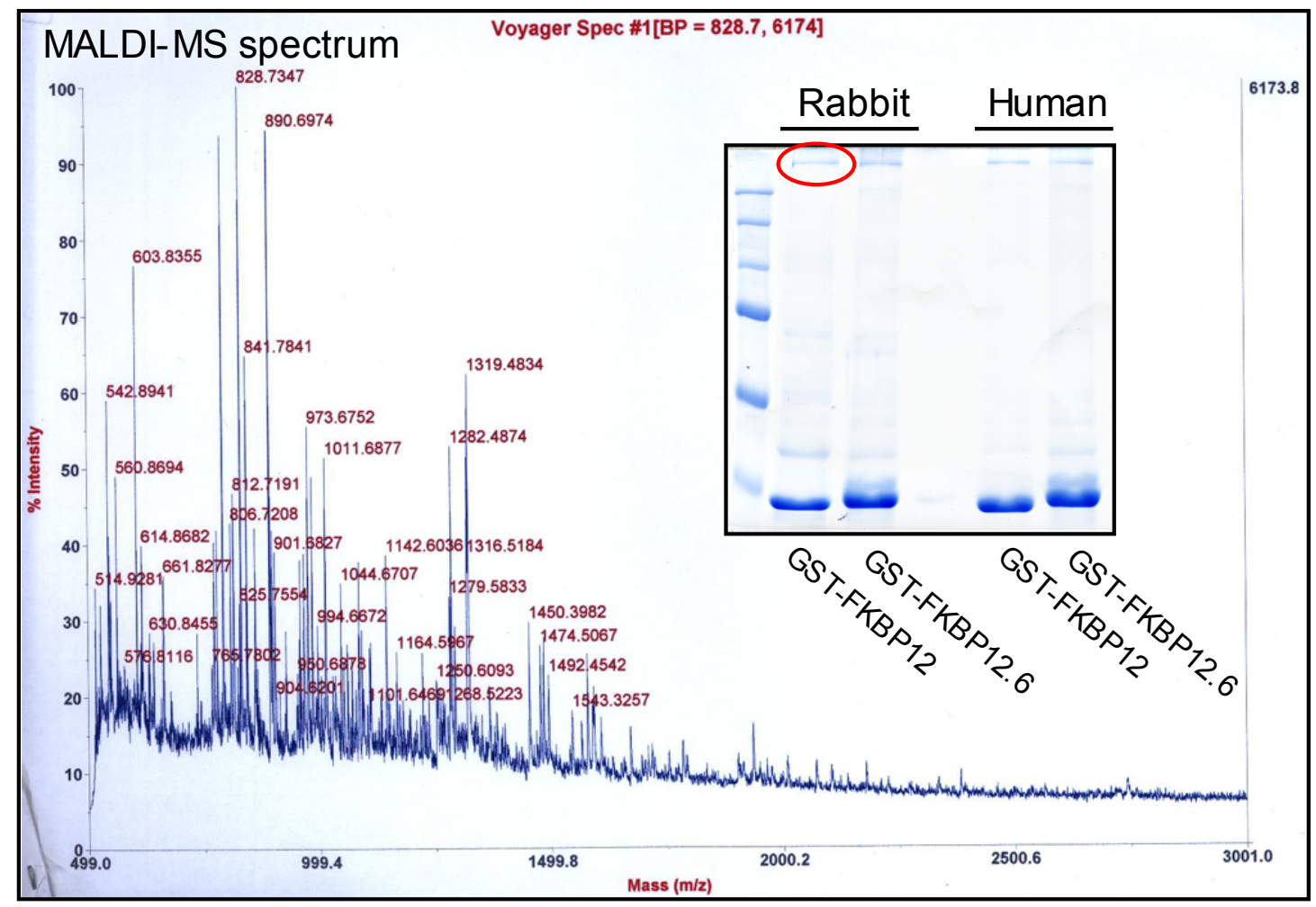

\section{$\left\{\begin{array}{l}\text { MATRRIX } \\ \text { SCIENCE Mascot Search Results }\end{array}\right.$ \\ Database : MSDB 20031106 (1268261 sequences; 402980146 residues) \\ Timestamp : 28 Nov 2003 at 14:43:09 GMT \\ Top Score : 88 for $Q 29621$, Cardiac RYANODINE receptor.- Oryctolagus cunicul \\ Probability Based Mowse Score}

Score is $-10^{*} \log (\mathrm{P})$, where $\mathrm{P}$ is the probability that the observed match is a random event.

Protein scores greater than 74 are significant $(\mathrm{p}<0.05)$.

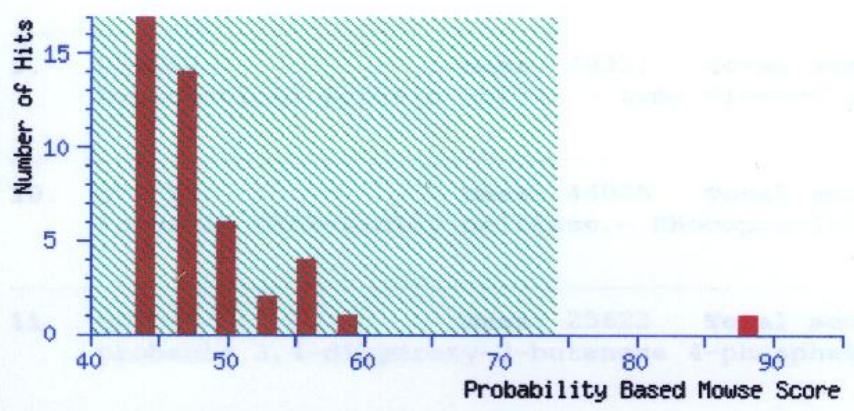

Concise Protein Summary Report

Mass: 564724 Total score: 88 Peptides matched: 51
Cardiac RYANODINE receptor. - Oryctolagus cuniculus (Rabbit).
A37113 Mass: 564712 Total score: 82 Peptides matched: 50
ryanodine receptor, cardiac muscle - rabbit

Figure 24. Protein identification by MALDI-TOF mass spectrometry. From the trypsin digestion profile, depicted as MALDI-MS spectrum (upper panel), high molecular weight protein extracted from the rabbit cardiac homogenate on the basis of its association with GST-FKBP12 (see inset depicting Coomassie Blue-stained gel, upper panel) was identified as cardiac isoform of RyR (see extract from Mascot Search Results, bottom panel). 

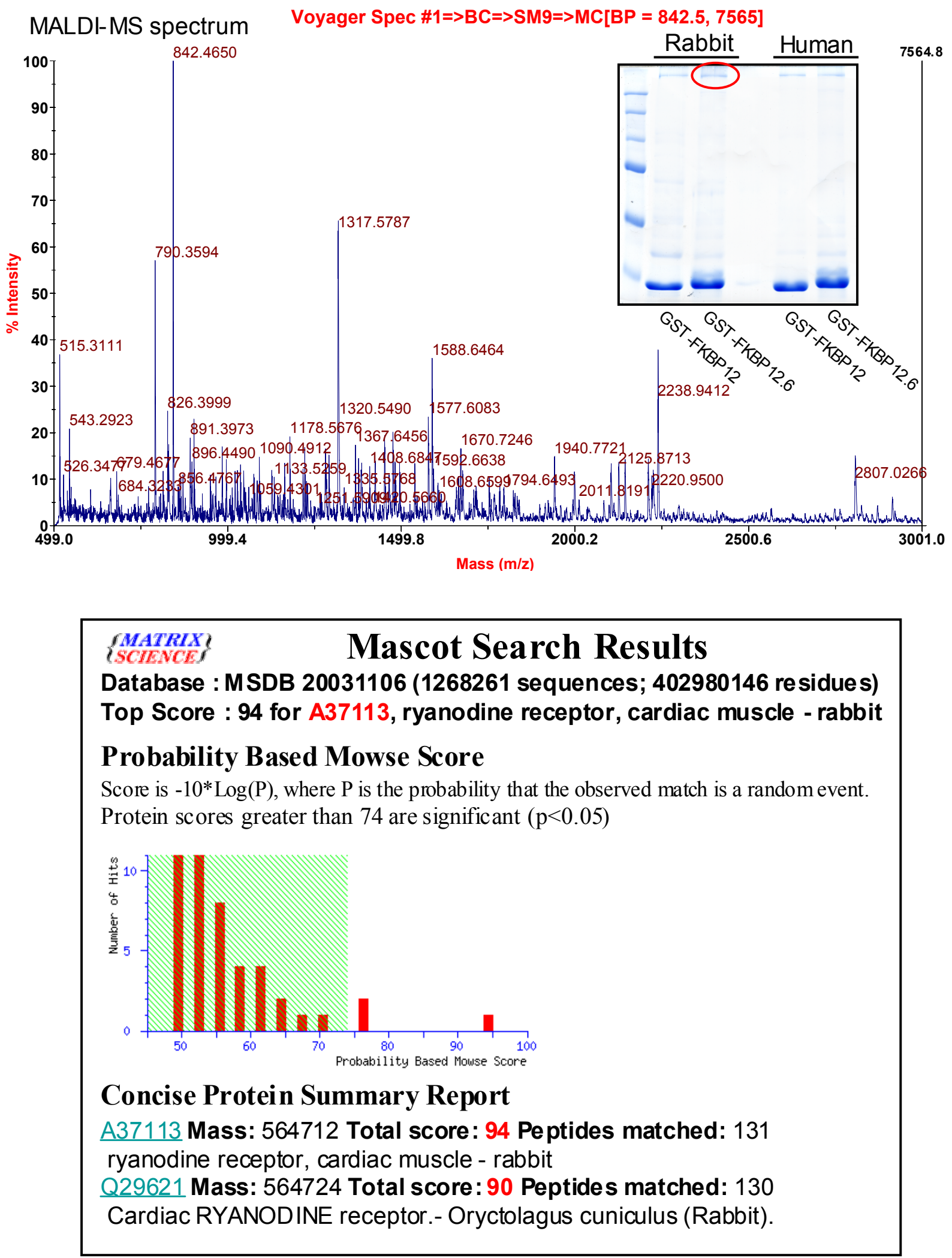

Figure 25. Protein identification by MALDI-TOF mass spectrometry. From the trypsin digestion profile, depicted as MALDI-MS spectrum (upper panel), high molecular weight protein extracted from the rabbit cardiac homogenate on the basis of its association with GST-FKBP12.6 (see inset depicting Coomassie Blue-stained gel, upper panel) was identified as cardiac isoform of RyR (see extract from Mascot Search Results, bottom panel). 

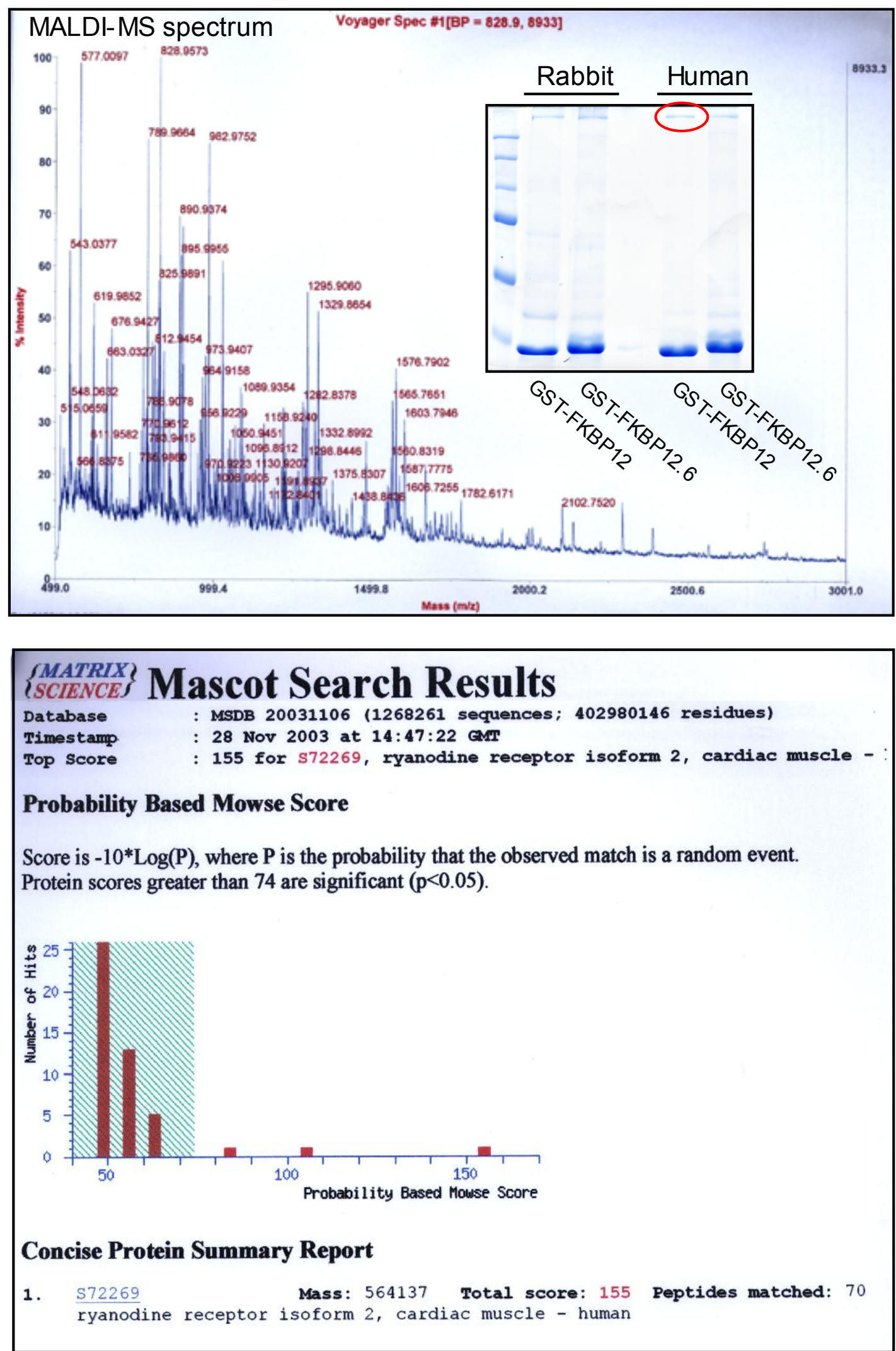

Figure 26. Protein identification by MALDI-TOF mass spectrometry. From the trypsin digestion profile, depicted as MALDI-MS spectrum (upper panel), high molecular weight protein extracted from the human cardiac homogenate on the basis of its association with GST-FKBP12 (see inset depicting Coomassie Blue-stained gel, upper panel) was identified as cardiac isoform of RyR (see extract from Mascot Search Results, bottom panel). 

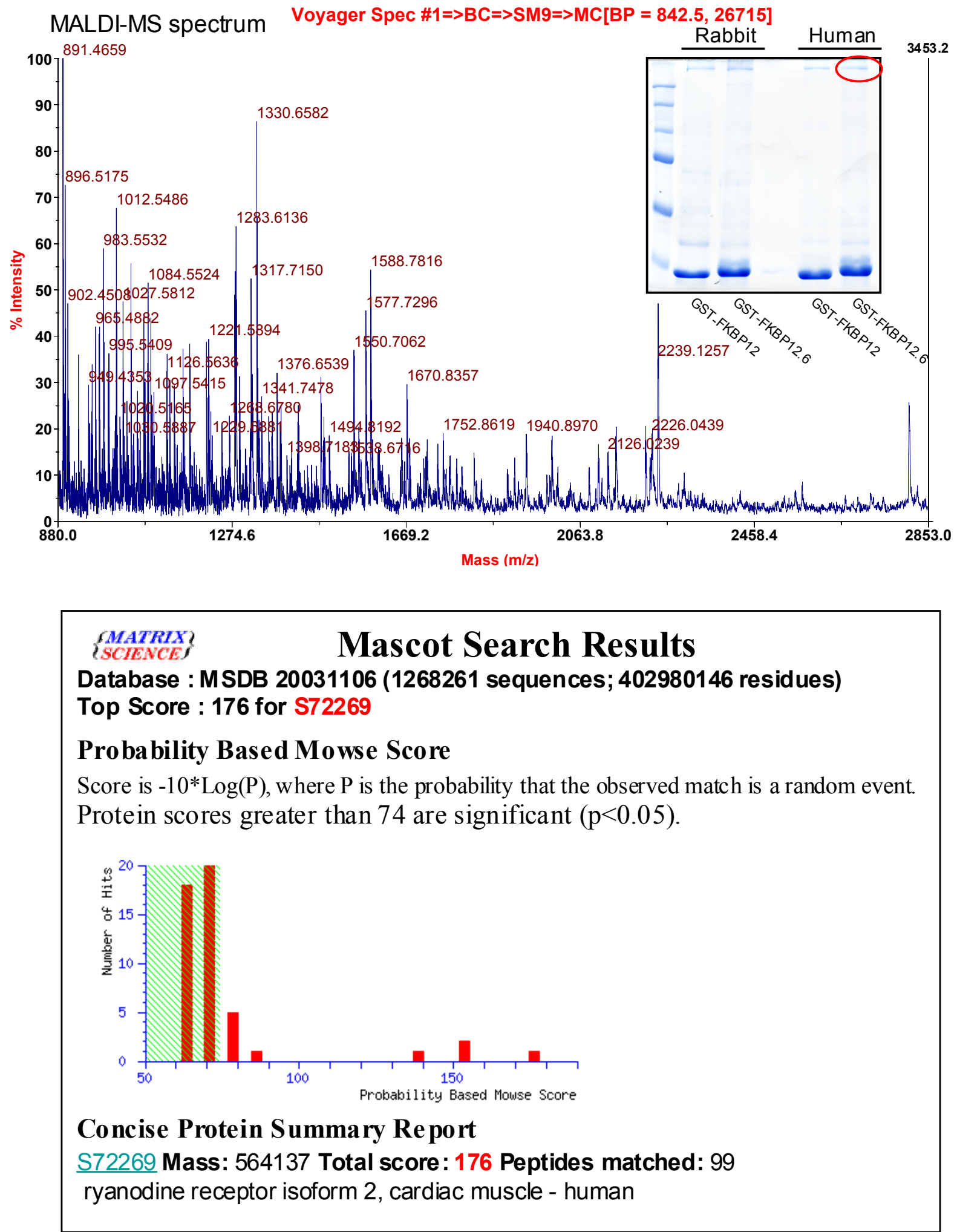

Figure 27. Protein identification by MALDI-TOF mass spectrometry. From the trypsin digestion profile, depicted as MALDI-MS spectrum (upper panel), high molecular weight protein extracted from the human cardiac homogenate on the basis of its association with GST-FKBP12.6 (see inset depicting Coomassie Blue-stained gel, upper panel) was identified as cardiac isoform of RyR (see extract from Mascot Search Results, bottom panel). 


\subsubsection{Canine RyR2 interacts with FKBP12.6 isoform exclusively}

To check whether dog really represents an exception where RyR2 interacts with FKBP12.6 only, and not with both FKBP isoforms, GST pulldown assay was applied to canine cardiac homogenate.

As shown in Figure 28A, GST-FKBP12.6 (lane 6) was able to pull down canine RyR2 in contrast to GST-FKBP12 (lane 3), whereas rabbit RyR2, probed in parallel, interacted with both GST-FKBP12 (lane 8) and GST-FKBP12.6 (lane 9). Analysis of the same precipitates by Western blot revealed that all canine RyR2 subjected to interaction with GST-FKBP12 remained unadsorbed, since it was completely recovered in the flowthrough fraction (Fig. 28C, lane 1). In contrast, GST-FKBP12.6 provided efficient extraction of RyR2 from the crude homogenate (Fig. 28C, lane 4 and 6).

To ensure that the complete absence of RyR2 in the eluate containing GST-FKBP12 is not due to insufficient elution, the elution step was repeated twice. Figure 28D demonstrates that none of the three eluates contains any detectable trace of RyR2 when GST-FKBP12 was used as a ligand (Fig. 28D, lanes 1-3).

Thus, it has been shown that unlike in other species, canine RyR2 interacts with FKBP12.6 exclusively. In addition, canine cardiac material may serve as negative control to make reliable conclusion from FKBP-RyR interaction studies. 

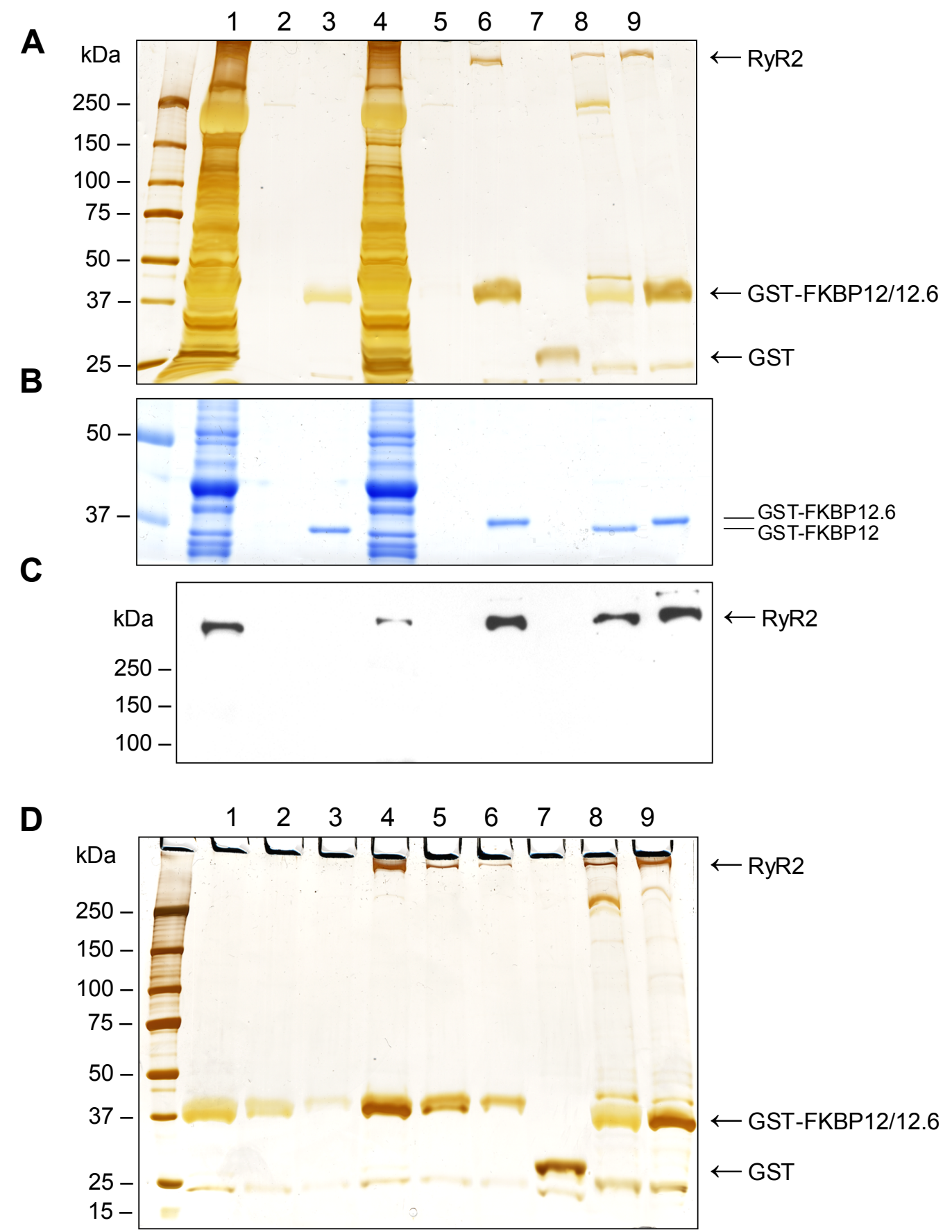

Figure 28. Affinity purification of RyR2 from canine cardiac homogenate based upon its specific association with FKBP12.6. Electrophoresis was carried out on $4-20 \%$ linear gradient (A and $C$ ) and 10\% (B) SDS-PAAGs and RyR was detected by silver staining (A) or by Western blot analysis using anti-RyR antibody (C). Lanes 1 and 4, the supernatant after adsorption of RyR-GST-FKBP12 and RyR-GST-FKBP12.6 complexes by glutathionesepharose 4B, respectively; lanes 2 and 5, the supernatant after washing RyR-FKBP12 and RyR-FKBP12.6 complexes immobilized on glutathione-sepharose, respectively; lanes 3 and 6, fractions bound to immobilized GST-FKBP12 and GST-FKBP12.6, respectively; lane 7, fraction bound to immobilized GST; lanes 8 and 9, affinity purification of RyR2 from rabbit cardiomyocyte homogenates using GST-FKBP12 and GST-FKBP12.6, respectively. (B) $10 \%$ SDS-PAAG stained with Coomassie Blue, demonstrating difference in electrophoretic mobilities of GST-FKBP12 and GST-FKBP12.6. (D) Silver-stained 4-20\% linear gradient SDSPAAG demonstrating elution profile of canine cardiac RyR2. Fractions 1-3 and 4-7, glutathione eluates from affinity chromatography using GST-FKBP12 and GST-FKBP12.6, respectively; fractions 8 and 9, affinity purification of RyR2 from rabbit cardiomyocyte homogenates using GST-FKBP12 and GST-FKBP12.6, respectively. 


\subsection{Overexpression of FKBP12.6 and FKBP12 in cardiomyocytes isolated from rabbit failing hearts}

To investigate whether FKBP12.6 and/or FKBP12 may represent new molecular target(s) to improve contractile function in heart failure, FKBP12.6 and FKBP12 were overexpressed by adenovirus-mediated gene transfer in cardiomyocytes isolated from rabbit failing hearts. Heart failure in rabbits was generated according to a technique established in our laboratory. In this animal model, heart failure was induced by 4-5 weeks of rapid ventricular pacing at a rate of 400 beats/minute with an externally programmable pacemaker. Sham-operated animals, in which a pacemaker was implanted but remained switched off, served as control. Development of heart failure was assessed by echocardiography at baseline, 2, 3 and 4 weeks. When the echocardiographic measurements in rabbit failing hearts had shown clear signs of heart failure including ventricular dilatation, decrease in heart fractional shortening, abdominal ascites, the failing-heart and sham-operated animals were sacrificed and tissue or cellular material were used for further experiments.

\subsubsection{Characterization of rabbit model of heart failure with respect to RyR2-FKBP12.6 association}

Recently, it has been shown that abnormal $\mathrm{Ca}^{2+}$ leak through $\mathrm{Ca}^{2+}$-release channels in human and canine heart failure is caused by partial loss of RyR-bound FKBP12.6 and a consequent conformational change in RyR. To assess the functional interaction of FKBP12.6 with RyR2 in rabbit failing heart, co-immunoprecipitation was performed. First, the protein level of RyR2 in rabbit failing myocardium was examined by immunoblotting using a polyclonal anti-RyR antibody. This revealed a significant reduction (54\%) of RyR2 protein level in failing myocardium when compared to shamoperated animals (Fig. 29A, B). A set of trial co-immunoprecipitation experiments was carried out in order to establish conditions at which equal amounts of RyR2 were precipitated by mouse-monoclonal anti-RyR antibody (34C clone, Affinity Bioreagents) from cardiac homogenates prepared from failing and sham myocardium. This facilitated further densitometrical quantification of FKBP12.6 co-immunoprecipitating with RyR2. For size-fractionation of formed complexes, 4-20\% linear gradient gel was used since its resolution capacity is high enough to resolve well both RyR2 (560 kDa) and FKBP12.6 $(12 \mathrm{kDa})$, despite huge difference in their electrophoretic mobilities. The use of this system allowed to normalize the densitometrically determined amount of co-immunoprecipitating FKBP12.6 for the amount of RyR2 precipitated. For 
visualization of RyR2 and FKBP12.6, rabbit polyclonal anti-RyR antibody and rabbit polyclonal anti-FKBP12 antibody (SA-169), respectively, were used. Indeed less FKBP12.6 co-immunoprecipitated with RyR2 in failing hearts compared to hearts from sham-operated animals (40\% reduction, $\mathrm{p}<0.05)$ (Fig. 30A, B), indicating that the interaction of RyR2 with its accessory protein FKBP12.6 is altered in the rabbit model of heart failure used for the present study.

A

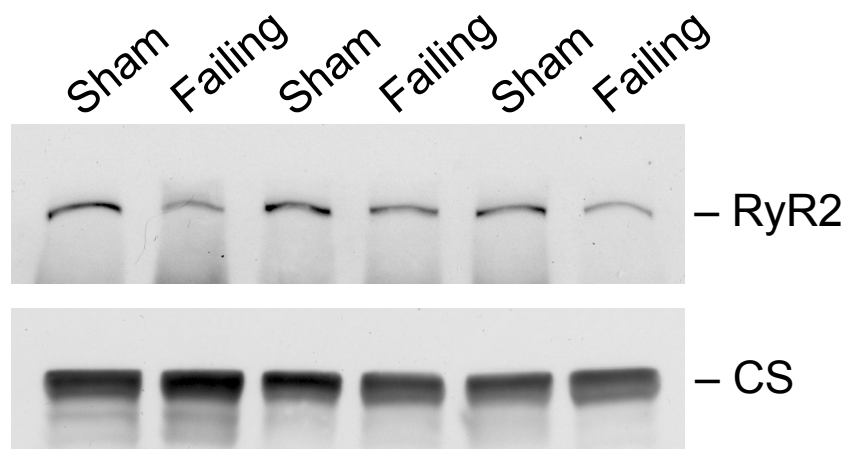

B

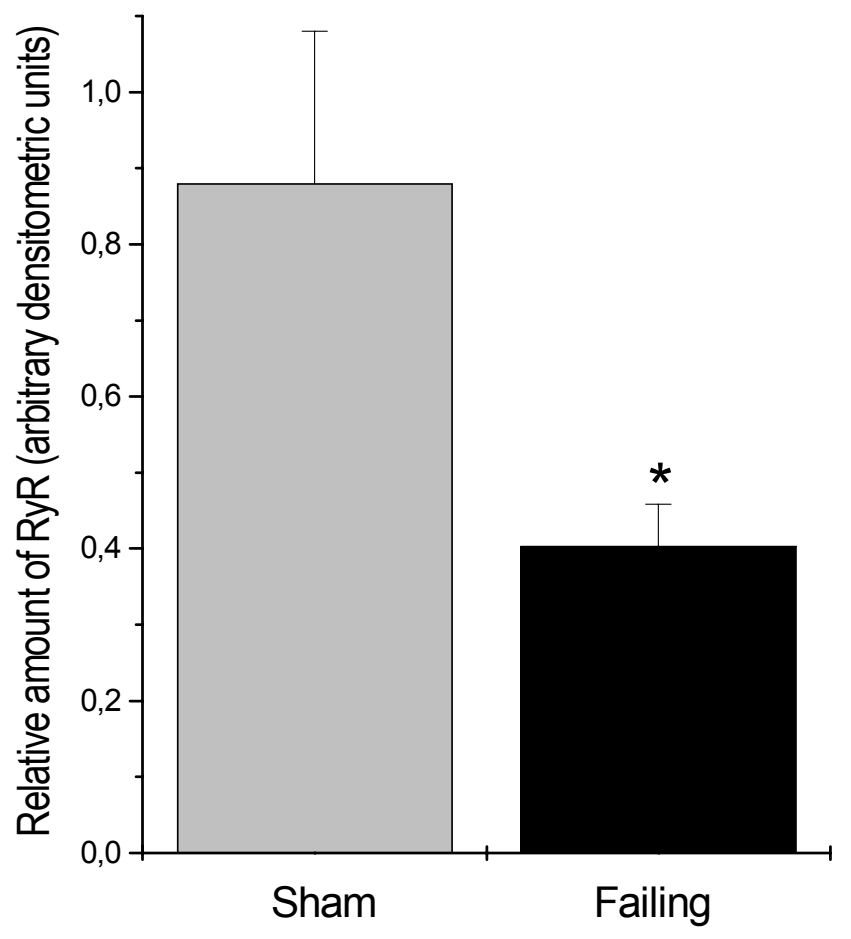

Figure 29. (A) Protein levels of RyR2 in rabbit failing myocardium and in myocardium from sham-operated rabbits. The myocardial homogenates were subjected to SDS-PAGE on $4-20 \%$ linear gradient gel and blotted with anti-RyR rabbit polyclonal antibody (upper panel). Western blot analysis with anti-CS antibody (bottom panel) using the same probes indicates equal protein load in each well. RyR2 and CS are indicated in the right margin. (B) Statistical comparison of RyR2 levels in myocardium from sham-operated and failing-heart rabbits. RyR2 protein levels normalized per calsequestrin were significantly reduced (by $\left.54 \%,{ }^{*} p<0.05\right)$ in failing myocardium $(n=4)$ compared to sham-operated animals $(n=3)$. Each individual value, given as relative amount of RyR, represents the mean of two independent determinations. Data are presented as mean \pm sem; comparison between sham and failing myocardium was performed by Student's $t$-test for unpaired values. 


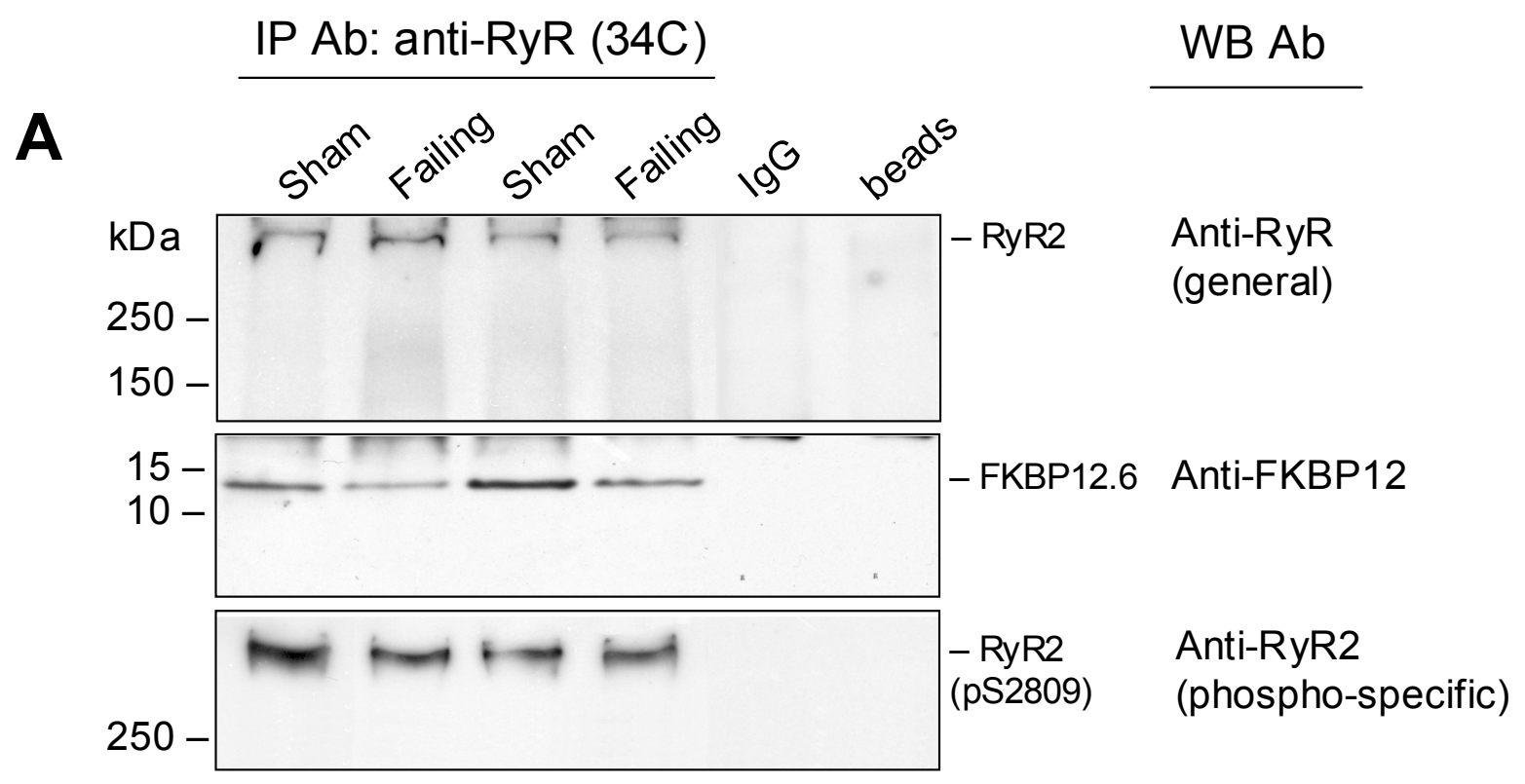

B

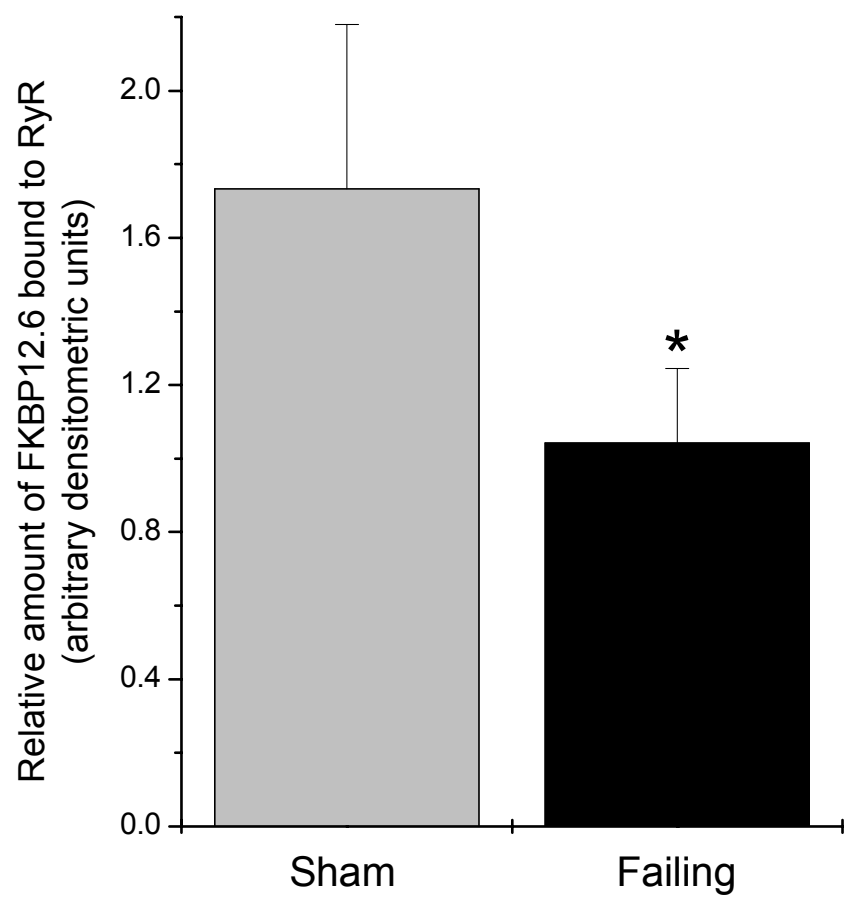

Figure 30. (A) Representative co-immunoprecipitation of RyR2 and FKBP12.6 from cardiac homogenates prepared from hearts of sham-operated and failing-heart rabbits. RyR2-FKBP12.6 complexes were immunoprecipitated and blotted with anti-RyR (upper panel), anti-FKBP12 (middle panel) and anti-phospho-RyR2 (S2809) (bottom panel) antibodies. (B) Quantification of FKBP12.6 associated with RyR2 in sham and failing hearts. There was significantly less FKBP12.6 (by $40 \%$, * $p<0.05$ ) co-immunoprecipitated with RyR2 from each of the failing hearts $(n=4)$ compared to sham controls $(n=4)$. The amount of FKBP12.6 was determined densitometrically and normalized for the amount of RyR2 precipitated. Data were analyzed by Student's $t$-test for unpaired values; error bars represent standard deviation of the mean. 


\subsubsection{Overexpression of FKBP12 and FKBP12.6 in cardiomyocytes isolated from rabbit failing hearts}

In order to assess the effect of overexpression, cardiomyocytes, isolated from rabbit failing hearts and subsequently infected with adenovirus, were cultured for only 24 hours, in contrast to non-failing cells which were maintained in culture for 48 hours prior to contractility measurements. This reduction of culture time was a compromise between time needed for transgene overexpression and cell quality, which becomes progressively impared during prolonged period of culturing up to 48 hours. For that reason, prior to contractility measurements, transgene expression at the protein level 24 hours post transfection was examined by immunoblotting. The cells were transfected with Ad-FKBP12 and Ad-FKBP12.6, both at MOI of 1, 1050 and 100. Immunoblotting revealed a specific dose-dependent increase of exogenous FKBP12 and FKBP12.6 proteins (Fig. 31A, B).

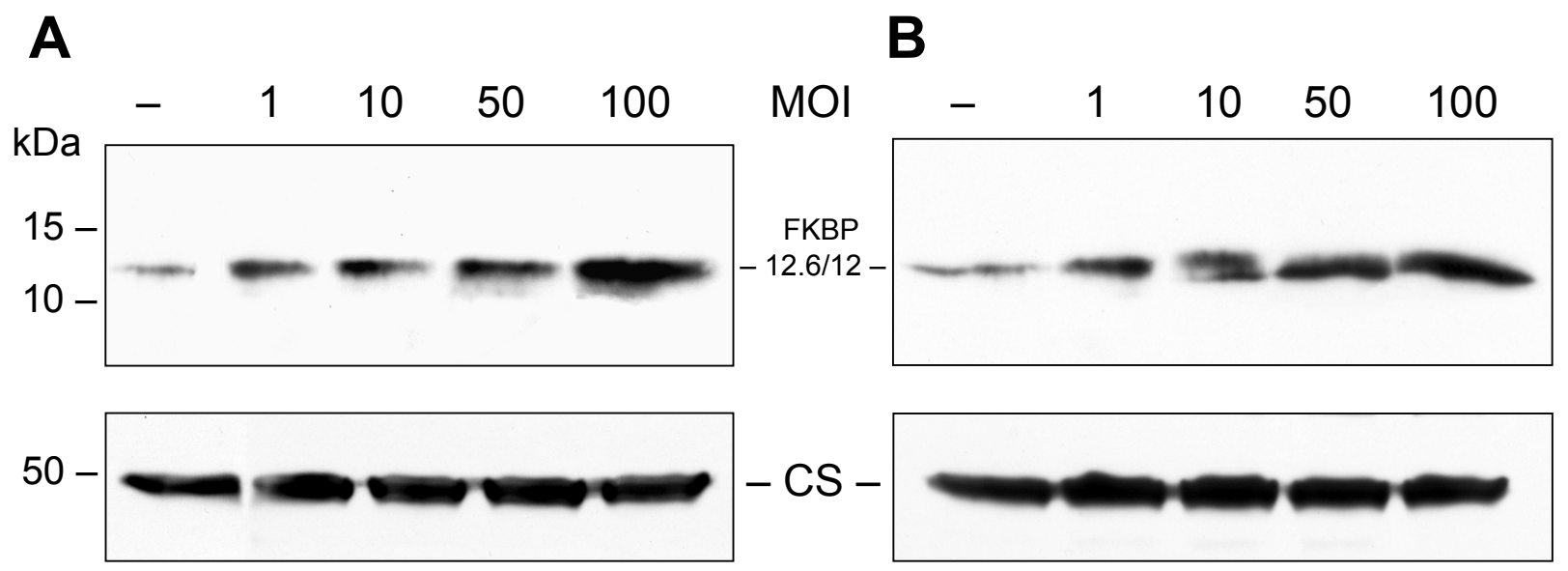

Figure 31. Western blot analysis of Ad-FKBP12.6 (A) and Ad-FKBP12 (B) infected myocytes isolated from rabbit failing heart. Cells were infected at the indicated $\mathrm{MOI}$ and were harvested 24 hours post transfection. Western blot analysis was performed with antiFKBP12 antibody to verify expression of exogenous FKBP12.6 (A, upper panel) and FKBP12 (B, upper panel); immunoblotting with anti-CS antibody (bottom panels) using the same probes indicates equal protein load in each well.

As determined densitometrically, $\mathrm{MOI} 100$ caused considerable but not excessive increase (up to 3 fold) in FKBP12.6 and FKBP12 productions. Therefore, for following physiological measurements, the cells were transfected at MOI of 100. 


\subsubsection{Contractility measurements of Ad-FKBP12 and Ad-FKBP12.6 transfected} cardiomyocytes isolated from rabbit failing hearts and hearts of sham-operated rabbits

The contractility of isolated rabbit cardiomyocytes was measured by video-edge detection 24 hours post transfection. Contractility measurement experiments were designed as follows: two groups of cells were isolated (rabbit failing hearts vs. hearts of sham-operated rabbits); adenoviral infection with an $\mathrm{MOI}$ of 100 was performed within each group to produce three populations of adenovirus transfected cardiomyocytes (i) overexpressing FKBP12 (Ad-FKBP12), (ii) FKBP12.6 (Ad-FKBP12.6) and (iii) expressing $\beta$-galactosidase as control (Ad-LacZ).

To get an idea to what extent contractile function of the heart is depressed during heart failure, values of fractional shortening of Ad-LacZ-transfected cardiomyocytes of both groups were compared (Fig. 32). As shown in Figure 32, fractional shortening of failing cardiomyocytes was significantly reduced (by $25 \%$ ) compared to cardiomyocytes isolated from hearts of sham-operated rabbits $(1.77 \pm 0.1 \%, \mathrm{n}=84$, vs. $2.35 \pm 0.1 \%, \mathrm{n}=101$, respectively; $p<0.001$ ).

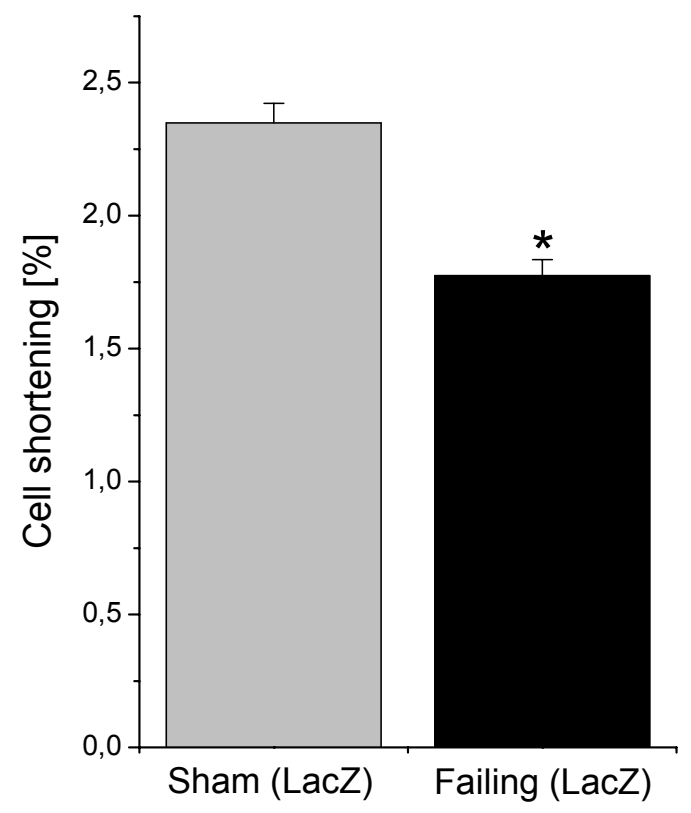

Figure 32. Statistical analysis of fractional shortening of cardiomyocytes isolated from rabbit failing hearts and hearts of sham-operated rabbits. Measurements were performed 24 hours post transfection. When compared to cardiomyocytes isolated from sham-operated animals, cell shortening of failing cardiomyocytes was reduced by $25 \%(2.35 \pm 0.1 \%, n=101$ vs. $1.77 \pm 0.1 \%, n=84$, respectively, $\left.{ }^{*} p<0.001\right)$. Mean \pm sem values average the fractional shortening of the cells $(n)$, comprising one population. Value of fractional shortening obtained for each cell is the average of 8 beatings. Data were analyzed by Student's $t$-test for unpaired values.

To investigate whether FKBP12 and/or FKBP12.6 may restore, at least in part, the impaired contractile function of failing cardiomyocytes, FKBP12 and FKBP12.6 were 
overexpressed by adenovirus-mediated gene transfer in rabbit myocytes isolated from failing hearts. In the failing-heart group, cardiomyocytes overexpressing FKBP12.6 showed a statistically significant increase in fractional shortening in comparison with LacZ transfected cells $(1.96 \pm 0.1 \%, n=102$ vs. $1.77 \pm 0.1 \%, n=84$, respectively; $p<0.05)$ (Fig. 33), indicating a partial restoration of contractile function. In the FKBP12overexpressing group, the trend towards improved contractility did not reach statistical significance $(1.90 \pm 0.1 \%, n=87$ vs. $1.77 \pm 0.1 \%$ of LacZ control, $n=84, p=0.2)$ (Fig. 33).

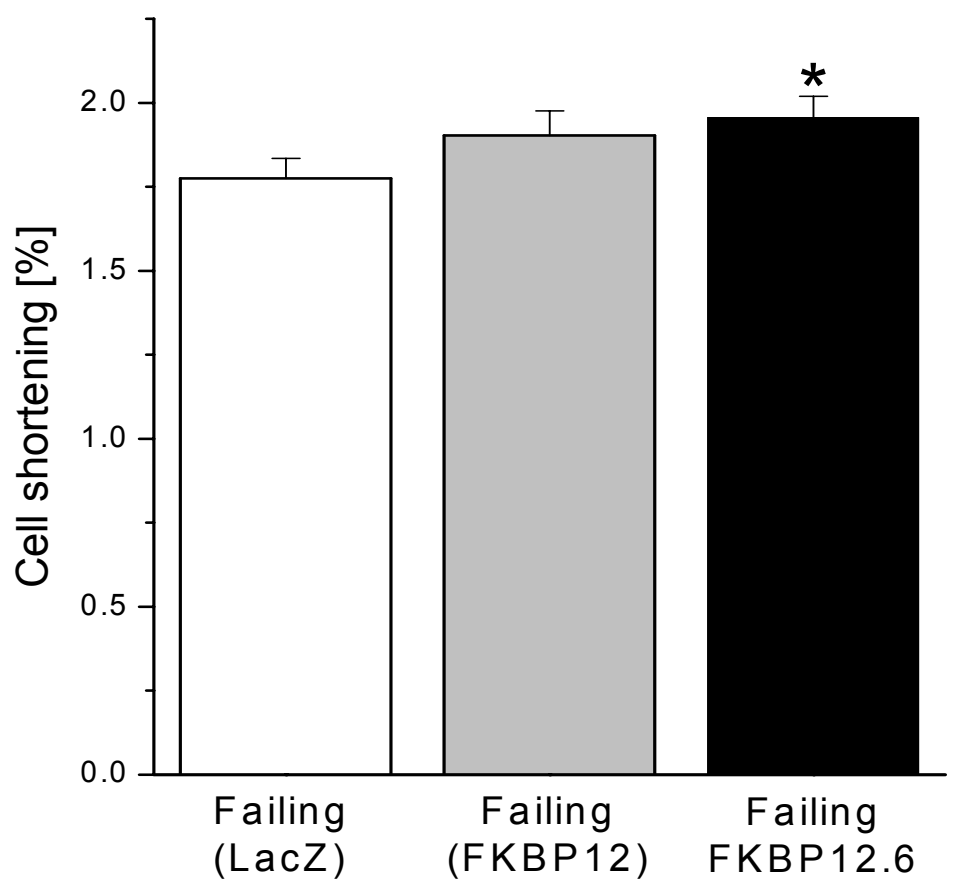

Figure 33. Statistical analysis of fractional shortening of rabbit failing cardiomyocytes overexpressing FKBP12 and FKBP12.6. Measurements were performed 24 hours post transfection. Cell shortening expressed in percentage of diastolic cell length was higher in AdFKBP12.6 infected cells compared to cells infected with Ad-LacZ (control) $(1.96 \pm 0.1 \%, n=102$ vs. $1.77 \pm 0.1 \%, n=84$, respectively, $\left.{ }^{*} p<0.05\right)$ as well as in Ad-FKBP12 infected cells when compared to LacZ control, $(1.90 \pm 0.1 \%, n=87 \%$ versus $1.77 \pm 0.1 \%, n=84)$, however in the latter case, the difference did not reach statistical significance $(p=0.2)$. Mean \pm sem values average the fraction shortening of the cells $(n)$, comprising one population. Cells obtained in the course of 7 individual isolations from failing hearts were subjected to contractility measurements. The value of fractional shortening obtained for each cell is the average of 8 beatings. Data were analyzed by Student's $t$-test for unpaired values.

In the sham group, a significant increase in contractility of cardiomyocytes overexpressing FKBP12.6 was observed $(2.64 \pm 0.1 \%, n=109$ vs. $2.35 \pm 0.1 \%$ of LacZ control, $n=101$, respectively) (Fig.34). A similar increase was measured in cells overexpressing FKBP12 $(2.62 \pm 0.1 \%, n=108$ vs. $2.35 \pm 0.1 \%$ of LacZ control $n=101$, $p<0.05)$ (Fig. 34). Results obtained in the sham group are consistent with the positive inotropic effect observed for both FKBP12.6 (data previously reported in our group by Prestle et al.) and FKBP12 (data reported in the present study) in non-failing 
cardiomyocytes. The similarity of the inotropic effects achieved with FKBP12 and FKBP12.6 overexpression in this part of the present study further underlines the equivalence of FKBP12 and FKBP12.6 as regulators of cardiac RyR in rabbit myocardium.

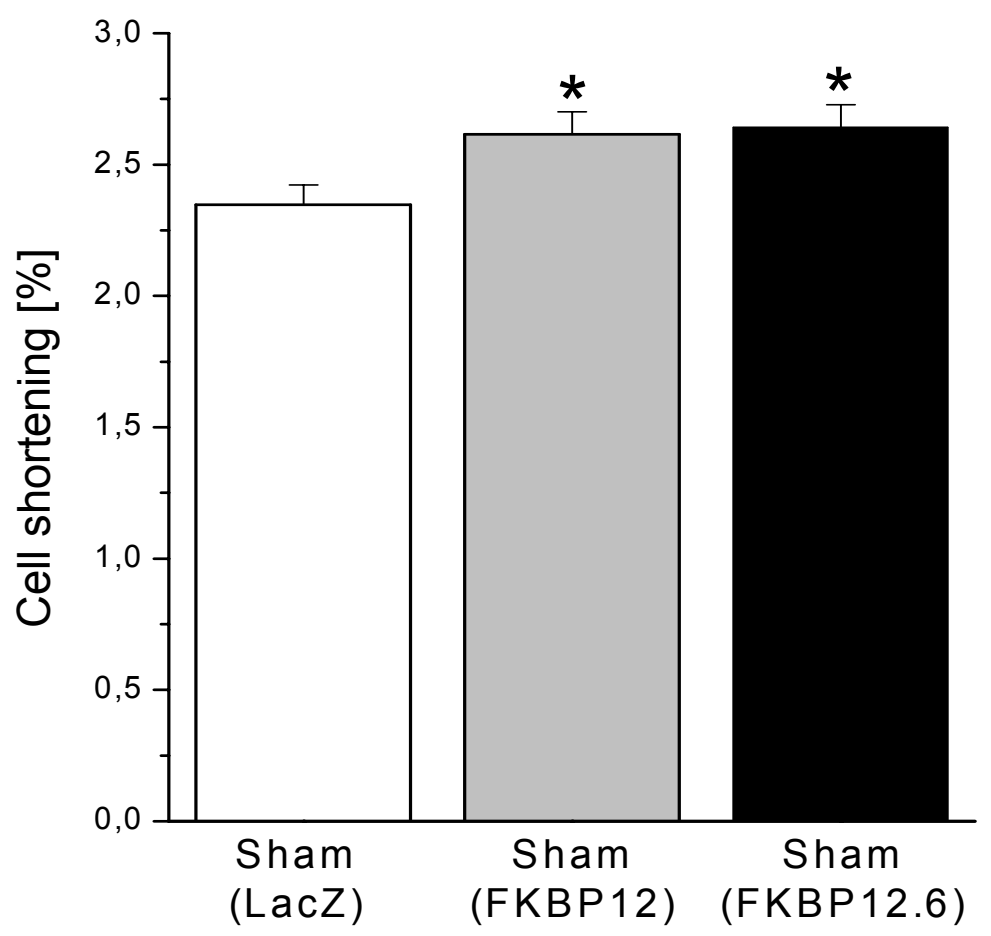

Figure 34. Statistical analysis of fractional shortening of cardiomyocytes, isolated from hearts of sham-operated rabbits, overexpressing FKBP12 and FKBP12.6. Measurements were performed 24 hours post transfection. Cell shortening was $12 \%$ higher in both FKBP12.6 $\left(2.64 \pm 0.1 \%, n=109\right.$ vs. $2.35 \pm 0.1 \%$ of LacZ control, $\left.n=101,{ }^{*} p<0.05\right)$ and FKBP12 $(2.62 \pm 0.1 \%$, $\mathrm{n}=108$ vs. $2.35 \pm 0.1 \%$ of LacZ control $\left.\mathrm{n}=101,{ }^{*} \mathrm{p}<0.05\right)$ overexpressing cardiomyocytes. Mean \pm sem values average the fraction shortening of the cells, comprising one population. Cells obtained in the course of 8 individual isolations from hearts of sham-operated animals were subjected to contractility measurements. The value of fractional shortening obtained for each cell is the average of 8 beatings. Data were analyzed by Student's $t$-test for unpaired values.

\subsubsection{Retrieval of FKBP12.6-RyR2 association upon overexpression}

To investigate whether overexpression of FKBP12.6 really leads to retrieval of FKBP12.6-RyR2 interaction, the levels of FKBP12.6 associated with RyR2 after overexpression were assessed by co-immunoprecipitation. First, it was confirmed that less FKBP12.6 was associated with RyR2 in cardiomyocytes isolated from failing hearts compared to sham controls (Fig. 35A, top and middle). In another experiment, cardiomyocytes isolated from failing hearts were transfected with Ad-FKBP12.6 at different $\mathrm{MOI}(0,10$ and 100) and cultured for 24 hours. Equal amounts of cell homogenates (500 $\mu \mathrm{g}$ protein), prepared from failing cardiomyocytes (non-transfected and transfected) and cardiomyocytes of sham-operated rabbits, were subjected to immunoprecipitation with anti-RyR antibody. At equal amounts of RyR2 precipitated in 
each sample, less FKBP12.6 was associated with RyR2 in non-transfected failing cells compared to sham control, whereas in transfected failing cells, significant and dosedependent retention of FKBP12.6 on RyR2 was observed (Fig. 35B). Interestingly, after FKBP12.6 overexpression, the association of FKBP12.6 with RyR2 not only reached but even exceeded the control level.

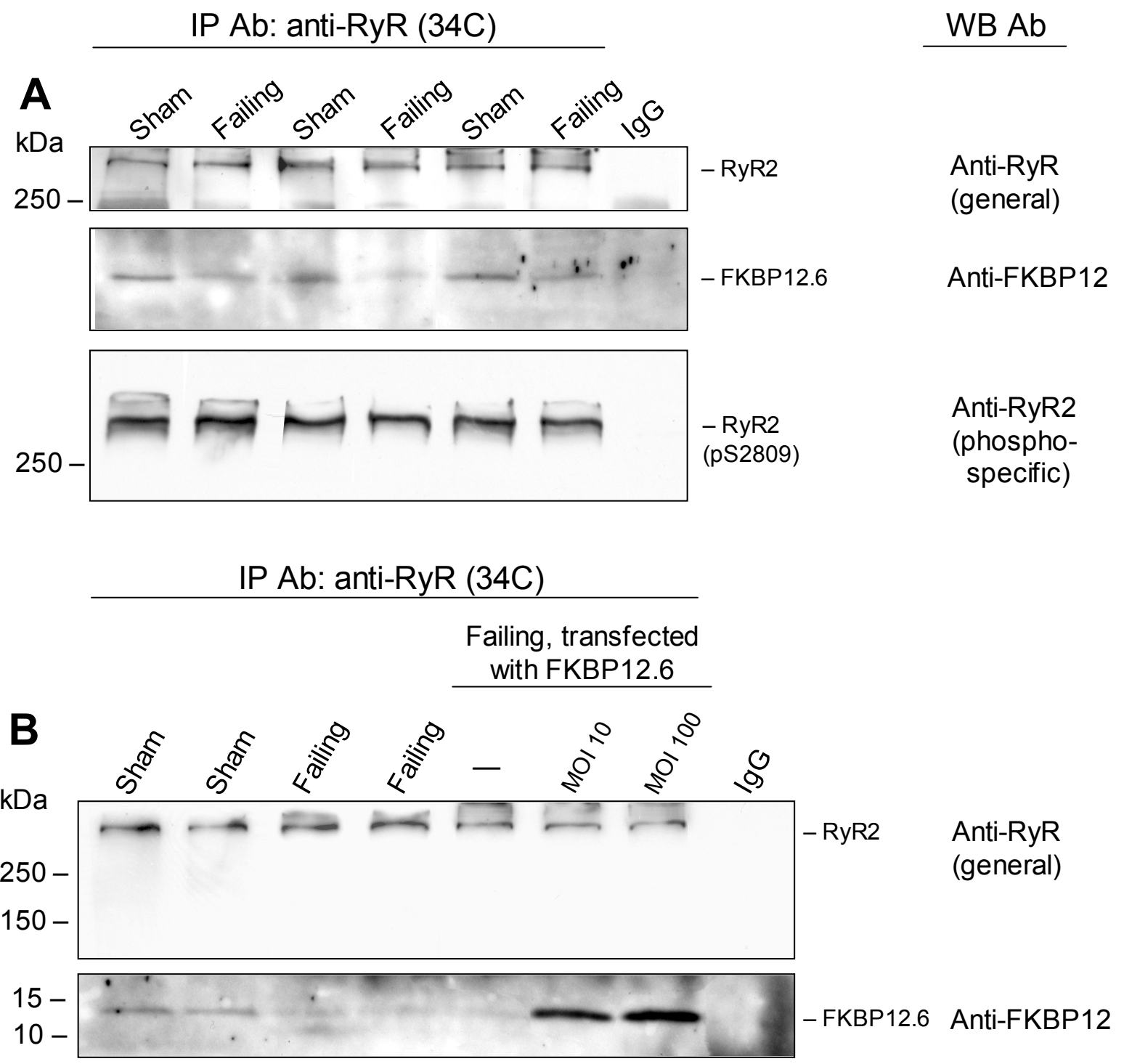

Figure 35. (A) Representative co-immunoprecipitation of RyR2 and FKBP12.6. Cell lysates used for co-immunoprecipitation were prepared from cardiomyocytes isolated from hearts of sham-operated and failing-heart rabbits. The RyR2-FKBP12.6 complexes were immunoprecipitated and blotted with anti-RyR (upper panel), anti-FKBP12 (middle panel) and anti-phospho-RyR2 (S2809) (bottom panel) antibodies. (B) Co-immunoprecipitation of RyR2 and FKBP12.6 demonstrating retention of FKBP12.6 on RyR2 in failing cardiomyocytes after transfection with Ad-FKBP12.6. Cardiomyocytes isolated from rabbit failing heart were transfected with Ad-FKBP12.6 taken at MOI of 10 and 100 and cultured for 24 hours. In immunoprecipitates obtained from transfected failing cells, the level of FKBP12.6 associated with RyR2 was considerably higher compared to non-transfected failing cells and exceeded the amount of FKBP12.6 co-immunoprecipitating with RyR2 in cardiomyocytes of shamoperated animals. 
From the given observations, it was assumed that overexpression of exogenous FKBP12.6 leads to retention of FKBP12.6 associated with RyR2, and, as a physiological consequence, increase of contractility occurs. The fact that the level of FKBP12.6 associated with RyR2 in failing cells upon overexpression exceeds the amount of FKBP12.6 associated with RyR2 under normal conditions implies the availability of free FKBP-binding sites on the RyR2 tetramer in normal heart. Free sites become occupied by exogenous FKBP12.6 during FKBP12.6 overexpression.

\subsection{Phosphorylation status of RyR2 in rabbit failing heart}

Recently, it has been reported that specific phosphorylation of RyR2 by PKA is significantly elevated in failing human and canine hearts. Moreover, it has been shown that phosphorylation of RyR2 by PKA in vitro dissociates FKBP12.6 from RyR2 and FK506-binding protein cannot rebind to PKA-hyperphosphorylated ryanodine receptor. The results, elucidated in 4.4 .3 and 4.4 .4 , constitute certain discrepancy with these observations. The very fact that excess exogenous FKBP12.6 could bind RyR2 under experimental conditions used in our study indicates that the role of RyR2 hyperphosphorylation in the regulation of FKBP12.6-RyR2 association might be overestimated, on one hand and on the other, raises doubts as to the hyperphosphorylation of RyR2 itself during heart failure. As a whole, phosphorylation of ryanodine receptor and its regulation via phosphorylation in heart failure is currently an unresolved issue. Therefore, an attempt to investigate the phosphorylation status of RyR2 in our rabbit model of heart failure was undertaken.

To examine the phosphorylation status of RyR2 in rabbit failing hearts, immunoblotting with anti-RyR2 antibody specific for phosphorylated serine 2809, the site phosphorylated by PKA, was performed. The use of this antibody, which was characterized and shown to recognize phosphorylated RyR2 only, made possible the direct assessment of phosphorylation levels of RyR2 in heart failure. Considering a general decrease of RyR2 levels in failing hearts (Fig. 29), precise estimation of its phosphorylation status using whole cardiac homogenates is difficult. To make the comparison of RyR2 phosphorylation in failing and sham hearts valid, immunoprecipitates of RyR2, obtained in the experiments described in 4.4.1 and 4.4.4, were blotted with both anti-RyR general and anti-RyR phosphospecific antibodies. As depicted in Figure 30A, at equal amounts of RyR2 in each sample (upper panel), there were no changes observed in the phosphorylation level of RyR2 (Fig. 30A, bottom panel) in failing hearts in comparison with hearts from control sham-operated animals. 
Similar results were obtained when blotting RyR immunoprecipitates from rabbit sham and failing cardiomyocytes (Fig. 35A, bottom panel).

From these results, it was concluded that in rabbit failing heart, RyR2 is not hyperphosphorylated, and if so, then loss of FKBP12.6 associated with RyR2 is independent of the phosphorylation status of RyR channel. 


\section{DISCUSSION}

\subsection{FKBP12 is relevant to the regulation of cardiac E-C coupling: physiological evidence}

FK506-binding protein is a soluble receptor for the immunosuppressant drug FK506. One of the cellular, FK506-independent, functions of FKBP12 and its orthologous isoform FKBP12.6 is coordination of the SR $\mathrm{Ca}^{2+}$-release channel.

According to the current concept based on co-purification and co-immunoprecipitation experiments, FKBP12.6 is tightly bound to cardiac isoform of the ryanodine receptor (RyR2) (Timerman et al., 1994; Lam et al., 1995), whereas FKBP12 associates with the skeletal muscle RyR isoform (RyR1) (Jayaraman et al., 1992; Timerman et al., 1993).

It was observed that FKBP12 is not only present in heart tissue but is much more abundant than FKBP12.6 (Timerman et al., 1994; Lam et al., 1995). In in vitro experiments, Timerman et al. showed that only FKBP12.6 exchanges with endogenously bound FKBP12.6 or rebinds to FKBP-stripped cardiac SR, whereas both FKBP isoforms bind to FKBP-stripped skeletal muscle $\mathrm{SR}$ and exchange with endogenously bound FKBP12 (Timerman et al., 1996). Xin et al. showed that the selectivity of FKBP12.6 binding to RyR2 is determined by 3 out of 18 amino acid residues which differ between FKBP12.6 and FKBP12 (Xin et al., 1999).

These early observations underlie the concept of isoform-specific regulation of RyRs by FKBPs, according to which, FKBP12.6 associates with and regulates cardiac RyR, whereas FKBP12 is associated with skeletal muscle RyR solely and, consequently, plays a role in RyR regulation only in skeletal muscle.

Certainly, the role of FKBP12.6 in the regulation of cardiac SR $\mathrm{Ca}^{2+}$ release is incontestable. However, it may well be that FKBP12 also plays an important role in cardiac E-C coupling, and there are several arguments as well as experimental data to prove that this assumption is not groundless. The fact that the levels of FKBP12 expressed in the heart are considerably higher than those of FKBP12.6 raises the question whether, despite possibly lower affinity, FKBP12 may contribute to the regulation of cardiac RyR. Another point is that in all above mentioned experiments, which demonstrated tight and selective association of FKBP12.6 but not FKBP12 with RyR2, canine heart was used as a prototype for studying the association of RyR2 with FKBPs. However, it was not known whether this selectivity of interaction also holds true for other species. This question was addressed by Jeyakumar et al., who demonstrated that cardiac SR in seven out of eight tested species (including representatives of five 
classes of vertebrates) contains both FKBP12 and FKBP12.6, and RyR2 from all these animals is capable of binding/exchanging with both FKBP12 and FKBP12.6, the only exception being dog (Jeyakumar et al., 2001). Other convincing evidence comes from the physiological studies of Shou et al., who by using FKBP12-knockout mice, showed that FKBP12 modulates calcium release in both skeletal and cardiac RyR (Shou et al., 1998). Since FKBP12 is highly conserved throughout eukaryotic phylogeny (Siekierka et al., 1990; Schreiber, 1991), it is logical to suggest that mouse is not the exclusive species where FKBP12 plays a major role in the heart. This assumption is consistent with findings of Jeyakumar and colleagues, demonstrating that the association of FKBP isoforms with RyR2 from SR of different vertebrates is conserved.

To investigate the role of FKBP12 in cardiac E-C coupling, adenovirus-mediated gene transfer was used in the present study to overexpress FKBP12 in isolated rabbit ventricular myocytes. This approach, previously used in our laboratory to overexpress FKBP12.6 in rabbit cardiomyocytes (Prestle et al., 2000; Prestle et al., 2001), has several advantages over previous experiments using an excess of immunosuppressive drugs (FK506 or rapamycin). When using these drugs for experiments with cardiomyocytes, their concentrations should be taken into consideration, because most of the drug will be buffered by cytosolic FKBP12. This phenomenon may underlie the controversy in literature concerning the effect of immunosuppressant drugs on intact ventricular myocytes (McCall et al., 1996; Xiao et al., 1997; duBell et al., 1997). In addition, when using FK506/rapamycin, it is not possible to discriminate between the effects of the two FKBP isoforms.

Adenoviral vectors are chosen for gene delivery into adult cardiomyocytes in primary culture. It is important that adenovirus infection itself does not affect the contractility of cardiomyocytes (Rust et al., 1998). A recombinant adenovirus that carries the human FKBP12 CDNA under the control of the CMV promoter was generated in our laboratory. An adenovirus carrying the lac $\mathbf{Z}$ gene, coding for $\beta$-galactosidase, served as a control virus.

Prior to physiological measurements, it was important to ensure that transfection and production of the transgene product are efficient. Highly efficient transfection was validated by $\beta$-galactosidase reporter gene assay (Fig. 9), and specific FKBP12 overexpression was confirmed by RT-PCR as well as Western blot assay (Fig. 10A, B). $\mathrm{MOI}$ of 100 was chosen for the physiological measurements, since at this multiplicity of infection, abundant production of transgene was achieved at $100 \%$ transfection 
efficiency. Achievement of a $100 \%$ transfection efficiency is an important factor to guarantee that every cell selected for contractility mearurements is transfected.

Using adenovirus-mediated gene transfer, it was shown that overexpression of FKBP12 in isolated rabbit cardiomyocytes increases the contractility of cardiomyocytes by $14 \%$ (Fig. 12). A similar positive inotropic effect of FKBP12.6 overexpression was reported previously by Prestle et al. (Prestle et al., 2001). It can be speculated that the positive inotropic effect of FKBP12 overexpression might be the result of more coordinated function of RyR2 and/or improved spatial coordination of neighboring channels promoted by FKBP12. The question how the overexpression of FKBP12 alters the activity of RyR2, considering that all FKBP-binding sites are occupied, may arise. Indeed, Timerman et al. estimated that on canine RyR2, only $\sim 17 \%$ of the total FKBP12.6-binding sites were unoccupied. If this were also the case in rabbit cardiomyocytes, that would mean that very few RyR2 are left for interaction with additional exogenous FKBP12. But, in rabbit cardiomyocytes FKBP12.6 is hardly expressed (Prestle et al., 2001), and therefore the stoichiometry of its interaction with RyR2 is, perhaps, by far, less than a ratio of $4: 1$, estimated from the in vitro binding studies (Timerman et al., 1996). Under these conditions, it may well be possible that FKBP12 compensates the low endogenous levels of FKBP12.6 and the overexpression of FKBP12 enhances this compensatory effect.

Timerman et al. showed that in skeletal muscle, the FKBP-RyR complex is in equilibrium with the cytosolic pool of FKBP12 (Timerman et al., 1995). Putative exchange of cytosolic FKBP12 with RyR2-bound FKBP12 is also likely to occur in the heart, where FKBP12 is more abundant than FKBP12.6. One can speculate that overexpression of FKBP12 results in modulation of RyR2 by changing the number of occupied FKBP-binding sites on RyR channels, which would be of relevance for the regulation of $\mathrm{E}-\mathrm{C}$ coupling.

\subsection{FKBP12 is relevant to the regulation of cardiac E-C coupling: molecular biology evidence}

On the basis of the contractility data, it was hypothesized that the possible mechanism underlying the effect of FKBP12 overexpression is FKBP12-RyR2 interaction.

Jeyakumar and colleagues, using the functional methodological approach, provided evidence that RyR2 from cardiac microsomes from representatives of five vertebrate classes (dog being the exception) is capable of exchange/binding to both FKBP 
isoforms. However, this observation was not validated, so far, with direct techniques used for protein-protein interaction studies.

In our attempts to define the mode of FKBP12/FKBP12.6-RyR2 interaction, more direct techniques such as co-immunoprecipitation and GST fusion protein pulldown assay were applied.

The co-immunoprecipitation data of the present study revealed that RyR2 can be coimmunoprecipitated with anti-FKBP12 antibody (Fig. 13A, lane 2). Although anti-FKBP12 antibody does not discriminate between the two FKBP isoforms, due to high homology of FKBP12 and FKBP12.6, these two isoforms are readily distinguished from one another due to difference in their electrophoretic mobilities. In spite of identical number of amino acid residues, the calculated molecular weight of FKBP12.6 is $127 \mathrm{Da}$ less than that of FKBP12, yet FKBP12.6 migrates apparently slower. As proposed by Sewell et al., a possible reason for such electrophoretic peculiarity is post-translational modification of FKBP12.6 (presumably phosphorylation of a serine residue either at position 39 or 40) (Sewell et al., 1994).

To ascertain whether both FKBP isoforms or only one of them (if so, then, which one) contributes to the co-immunoprecipitation of RyR2 with anti-FKBP12 antibody, coimmunoprecipitation with anti-RyR antibody was performed. This reciprocal experiment revealed that only one FKBP isoform, namely FKBP12.6, co-immunoprecipitates with RyR2 (Fig. 13B, C). Since FKBP12 and FKBP12.6 differ only slightly with respect to their electrophoretic mobilities, to ensure that the appearance of only one protein band, co-immunoprecipitated with RyR2, is not the result of insufficient protein separation, both FKBP recombinant isoforms were loaded side by side (or co-loaded in one well) to control the resolution capacity of the system used (Fig. 13C, lanes 3-4, D). Lower sensitivity of anti-FKBP antibody to FKBP12 compared to FKBP12.6 also does not seem to be the reason why only FKBP12.6 is observed in the precipitates, since both recombinant FKBP isoforms are recognized equally (Fig. 13C) and this antibody was used for detection of endogenous rabbit FKBP12 in numerous other cases (not shown here). This outcome was not surprising, for similar results were obtained for human (Marx et al., 2000; Reiken et al., 2003) and rat (Bandyopadhyay et al., 2000) utilizing co-immunoprecipitation approach. In view of observations of Jeyakumar et al., it is appropriate to expect co-immunoprecipitation of both FKBP isoforms with cardiac RyR in both human and rat. Thus, considering this analogy and the physiological evidence provided by the present study, it was supposed that the lack of co-immunoprecipitation of FKBP12 with cardiac RyR2 does not mean the absence of association, which 
prompted us to further investigate the association between FKBP12/12.6 and cardiac RyR utilizing GST fusion protein pulldown assay.

The pulldown assay data showed that in rabbit, GST-FKBP12 demonstrated specific interaction with RyR2 with high affinity and in a FK506 displaceable manner (Fig. 22). Similarly, both GST-FKBPs exhibited comparable interaction with human cardiac RyR (Fig. 23). In the case of human material, two native preparations were used for the interaction studies: a solubilized purified preparation (isolated RyR2) and a crude cardiac homogenate. Notably, both preparations displayed similar behavior with respect to the interaction of RyR2 with FKBP isoforms (Fig. 20A, Fig. 21A, Fig. 23). RyR1 isolated from rabbit skeletal muscle was used to control the binding properties of FKBP12 (Fig. 20B). In addition, this experiment was extended to probe the interaction of RyR1 with FKBP12.6. Under the given conditions, RyR1 was capable of binding to both FKBP12 and FKBP12.6, similar to the observations of Timerman et al. (Timerman et al., 1996), whereas the FKBP12-RyR2 interaction, reported here, is shown for the first time.

A number of procedures have been developed to purify skeletal and cardiac ryanodine receptor, including sequential column chromatography using heparin-agarose, hydroxyapatite and gel permeation chromatography (Inui et al., 1987a; Inui et al., 1987b), sucrose gradient centrifugation (Lai et al., 1988; Lindsay and Williams, 1991) and spermine agarose chromatography (Shoshan-Barmatz and Zarka, 1992). All these laborious techniques are feasible but they necessitate a considerable amount of starting material. GST-FKBP affinity chromatography is an alternative approach to purify RyR channels from limited amounts of biological material, for example from the heart of small animals or from cultured cells. In GST pulldown experiments reported here, raw lysates from rabbit cardiomyocytes and cardiac homogenates prepared from small amounts (up to $1 \mathrm{~g}$ ) of human heart were used as a source of RyR2. Figures 22 and 23 demonstrate that in terms of purity of the obtained RyR2, this approach is absolutely no less effective than conventional sucrose gradient purification, which also was utilized in the present study to isolate RyR (Fig. 15).

In immunoblot analysis that followed GST pulldown, an anti-RyR antibody which does not discriminate between the two RyR isoforms was used. Therefore, there is a risk of detecting RyR1 when using GST-FKBP12 as a ligand. Basing on the current concept, according to which, cardiac tissue is lacking significant amounts of RyR1, this risk is rather small. However, the possibility of trace expression of RyR1 in the heart is not groundless in view of recent data demonstrating the co-expression of three different 
RyR isoforms in both healthy and failing human heart (Munch et al., 2000; Munch et al., 2001). In addition, possible contaminations of starting material with RyR1-containing cells/tissue (for example fibroblasts or smooth muscle cells) may raise some concern. MALDI-TOF mass spectrometry was performed to rule this out. In the case of both rabbit and human, the high molecular weigh proteins precipitated with GST-FKBP12 matched perfect with the cardiac isoform of the ryanodine receptor (Fig. 24-27).

Another concern of the GST pulldown assay is its specificity and reliability. To validate the specificity of the assay described here, canine RyR2 was used as a negative control, since it was expected not to interact with FKBP12. On the other hand, probing interaction of canine RyR2 with both FKBP12 and FKBP12.6 in comparison with other species (rabbit and human) provide a good opportunity to verify the notion of Jeyakumar and colleagues, which was not validated so far with any of the direct techniques used for protein-protein interaction studies. Indeed, when subjected to the GST pulldown assay, canine RyR2 was able to interact with GST-FKBP12.6, but not with GSTFKBP12 (Fig. 28). This result supplements the data reported by Jeyakumar et al., thereby confirming that dog is really an exception in that canine RyR2 interacts with FKBP12.6 exclusively. This observation explains why the role of FKBP12 in the regulation of cardiac $\mathrm{E}-\mathrm{C}$ coupling was not in the focus of investigations for a while. In addition, use of canine cardiac RyR2 as a reliable control enabled us to validate newly acquired observations regarding FKBPs-RyR2 interaction in rabbit and human heart. The question what makes dog different from other species still remains. To answer it, one should look for structural differences between canine RyR2 and RyR2 of other species.

The main question which arises from the present interaction studies is why only FKBP12.6 isoform co-immunoprecipitates with RyR2, whereas, as was unambiguously shown here, both GST-FKBPs are able to pull down RyR2 with equal efficiencies. Several explanations are possible. One, in the solubilized native preparation used for co-immunoprecipitation, an interaction of FKBP12 with RyR2 might be lost in the course of the experiment, whereas in GST pulldown assay, the interaction is allowed to occur after solubilization. This explanation would imply less affinity of FKBP12-RyR2 interaction. The GST pulldown assay used in the present study was not intended for quantitative assessment of the interactions, therefore one of the future directions of FKBPs-RyR2 interaction studies might be the establishment of quantitative GST pulldown assay in order to gain deeper insight into the quantitative aspect of this 
interaction. An alternative explanation would be that the FKBP12-RyR2 interaction might be transient and therefore cannot be detected by co-immunoprecipitation.

\subsection{Levels of FKBP12.6 associated with RyR2 in rabbit model of heart failure}

RyR2 is proposed to be one of the central players in the contractile dysfunction of heart failure. One of the reasons for this consideration is the tight association of RyR2 with FKBP12.6, disruption of which produces unstable channels with subconductance states and increased open probability (Kaftan et al., 1996; Xiao et al., 1997). Similar alterations in RyR channel properties were observed in heart failure (Marx et al., 2000). Another group found abnormal $\mathrm{Ca}^{2+}$ leak in SR vesicles isolated from failing heart (Yano et al., 2000). Both groups showed that the stoichiometry of FKBP12.6 per RyR2 is significantly decreased in failing myocardium of human (Marx et al., 2000) and dog (Yano et al., 2000; Marx et al., 2000). Abnormal function of RyRs as a result of defective regulation by FKBP12.6 has been implicated in the pathogenesis of heart failure. However, some uncertainties in this regard have been mentioned in literature. Thus, in the study of Jiang et al., the effects of rapamycin on single $\mathrm{Ca}^{2+}$-release channels and $\left[{ }^{3} \mathrm{H}\right]$ ryanodine binding were the same for control and failing RyR2, indicating that FKBP12.6 remains associated with RyR2 to a similar extent in both groups (Jiang et al., 2002).

In the present study, a pacing-induced rabbit heart failure model was used. To specify whether FKBP12.6-RyR2 interaction is altered during heart failure, a functional association of FKBP12.6 with RyR2 in failing myocardium was assessed by coimmunoprecipitation. A 40\% reduction in the amount of FKBP12.6 associated with RyR2 from failing hearts compared to RyR2 from hearts of sham-operated animals was revealed (Fig. 30A upper and middle panels, B). This observation is consistent with data obtained using failing hearts from humans (Marx et al., 2000) and dogs with pacinginduced heart failure (Yano et al., 2000; Marx et al., 2000), and demonstrates the presence of a similar mechanism of cardiac dysfunction for these three species at the level of RyR2-FKBP12.6 interaction. Regarding the discrepancy with the results of Jiang et al., a possible explanation may be the utilization of principally different methodological approaches. The use of a straightforward procedure such as coimmunoprecipitation to determine protein association seems to be more advantageous over the functional approach used by Jiang and colleagues.

The most intriguing question remains to be the mechanism underlying the regulation of FKBP12.6-RyR2 association. According to Marks and co-workers, the regulation is realized by phosphorylation of RyR2 by PKA at serine-2809 and overstimulation of this 
process in heart failure strips the RyR2 of FKBP12.6 (Marks, 2000; Marks, 2001). This theory is based on the observations reported by Marx et al.: first, in vitro PKA phosphorylation of RyR2 dissociates FKBP12.6 from RyR2, resulting in altered channel properties; second, PKA-hyperphosphorylated RyR2 channels in failing hearts are depleted of FKBP12.6 and exhibit defects in single-channel properties similar to those observed in RyR2 channels hyperphosphorylated by PKA in vitro (Marx et al., 2000). A basic aspect of this theory, namely the PKA-dependent dissociation of FKBP12.6 from RyR2, was questioned by other groups which showed that PKA phosphorylation of RyR2 does not dissociate FKBP12.6 from the channel (Jiang et al., 2002; Xiao et al., 2004). Moreover, in the studies by Jiang and co-workers, the phosphorylation status of RyR2 from failing canine hearts was indistinguishable from that of RyR2 from normal hearts (Jiang et al., 2002).

In the present study, the phosphorylation levels of RyR2 immunoprecipitated from rabbit failing myocardium were examined using a phospho-serine-2809-specific anti-RyR2 antibody, provided by the group of Marks. This antibody has been reported to recognize only the phosphorylated form of RyR2 in several species including rabbit (A. Marks, personal communication). We found no increase in the phosphorylation status of RyR2 from failing hearts when compared to RyR2 from hearts of sham-operated rabbits (Fig. 30A, bottom panel, Fig. 35A, bottom panel).

To assess the phosphorylation status of RyR2, Jiang and colleagues used RyR channels embedded with SR microsomes, while Marx and co-workers used solubilized and immunoprecipitated RyRs. According to Jiang et al., the use of different RyR preparations might be a potential source of discrepancy concerning the phosphorylation status of RyR2 in failing heart. It is possible that immunoprecipitation concentrates phosphatases or kinases and favors nonphysiological reactions, which would not occur in more intact preparation (Jiang et al., 2002). Even though the experimental conditions employed in the present study were close to those of Marks and coworkers (Marx et al., 2000; Reiken et al., 2001; Reiken et al., 2003), still, the phosphorylation status of RyR2 in failing rabbit hearts was found not to be different from that in the hearts of sham controls. Of course, one can argue that the loss of hyperphosphorylation might occur during the experimental procedure. First, this should be prevented, at least in part, by introducing phosphatase inhibitors during immunoprecipitation procedure. Second, when dephosphorylation happens, being potentially promoted by the experimental conditions, it should equally affect the phosphorylation status of RyR2 in both failing and control hearts. The storage conditions of the tissue and time factor also do not seem to 
be of concern, since similar results were obtained when fresh cellular material from hearts of failing and sham-operated animals was subjected to immunoprecipitation (Fig. 35A). Also, if dephosphorylation of RyR2 at the PKA site really occurred for one or the other reason, it would be reasonable to expect reassociation of FKBP12.6 with dephosphorylated RyR2.

Considering the aforementioned, a partial loss of FKBP12.6 from RyR2 in heart failure is evident; however, in our experiments, it does not correlate with hyperphosphorylation of RyR2 in failing rabbit heart, suggesting that another mechanism, rather than PKA phosphorylation, may underlie the physiological regulation of FKBP12.6-RyR2 interaction.

\subsection{Restoration of contractile function of failing cardiomyocytes by overexpression of FKBP12 and FKBP12.6}

A prominent characteristic of several animal models of heart failure and human failing myocardium is a decreased contractility of individual cardiomyocytes (Beuckelmann et al., 1992; Gomez et al., 1997; Dipla et al., 1999; O'Rourke et al., 1999; Pieske et al., 1999). Several molecular alterations are thought to be relevant to abnormal $\mathrm{Ca}^{2+}$ cycling, thereby contributing to depressed cardiac performance in heart failure (Hasenfuss, 1998; Houser et al., 2000). Defective FKBP12.6-RyR2 interaction, which causes depletion of $\mathrm{SR} \mathrm{Ca}^{2+}$ store, contributes, at least in part, to the reduced contractility of cardiomyocytes in failing heart.

In the present study, it was investigated whether overexpression of exogenous FK506-binding proteins would improve contractility of rabbit failing cardiomyocytes. In the rabbit model used for the present study, the contractility of failing cardiomyocytes was decreased by $25 \%$, when compared to sham control (Fig. 32). In the failing-heart group, the amplitude of single cell shortening was increased in FKBP12.6 overexpressing cells (by 11\%) in comparison with that of LacZ control (Fig. 33); FKBP12 overexpressing cells exhibited a trend towards improvement in contractility (Fig. 33). This study provides the first indication that FKBP12.6 overexpression restores, in part, contractile function of rabbit failing cardiomyocytes.

In the sham group, overexpression of both FKBP12.6 and FKBP12 caused a significant increase in cardiomyocyte contractility (by 12\%) when compared to LacZ control (Fig. 34), this is consistent with the positive inotropic effect of both FKBP12.6 (Prestle et al., 2001) and FKBP12 (observed in the present study) in non-failing rabbit cardiomyocytes. In the current study, the increase in fractional shortening observed 
after overexpression of FKBPs in cardiomyocytes isolated from sham-operated animals was somewhat smaller than that found in non-failing cells (21\% and 14\% for FKBP12.6 and FKBP12 overexpression, respectively) (Prestle et al., 2001; this study). This can be explained by lesser extent of transgene expression 24 hours post transfection. Similarly, in the report by Prestle et al., at a lower level of FKBP12.6 overexpression 24 hours post transfection, fractional shortening measured was only 15\% higher in FKBP12.6 overexpressing cells as compared to LacZ control (Prestle et al., 2001).

The present study provides evidence that FKBP12 is relevant to the regulation of cardiac E-C coupling and is able to interact with RyR2 (see 4.2 and 4.3.2). The interplay between the two FKBP isoforms in the heart, specifically in the failing heart, is of interest. One can speculate that in the heart, where FKBP12.6 expression levels are low, FKBP12 could compensate for these low levels of FKBP12.6 and in the failing heart this compensation appears to be more significant. Under such circumstances, the sensitivity of overexpression approach is not high enough to reveal the functional consequences, which would explain why in our experiments, the trend towards improved contractility in failing cells overexpressing FKBP12 did not reach statistical significance.

FKBP12.6 overexpression restored $44 \%$ of the contractile function. Heart failure is a complex disorder and changes in the expression levels or activity of a multitude of important $\mathrm{Ca}^{2+}$-regulatory molecules contribute to depressed cardiac performance (Houser et al., 2000). Among the most crucial factors are abnormal density/function of $\mathrm{Ca}^{2+}$ uptake (realized by SR Ca ${ }^{2+}-$ ATPase) and extrusion (realized by $\mathrm{Na}^{+}-\mathrm{Ca}^{2+}$ exchanger) (Dipla et al., 1999; Pieske et al., 1999; Hobai and O'Rourke, 2000); downregulation of RyR2 expression [(Cory et al., 1993; Go et al., 1995); present study (Fig. 29)]; decrease of RyR2 activity (O'Brien et al., 1994) and its abnormal regulation (Yano et al., 2000; Marx et al., 2000). Considering this complexity, one can not expect complete compensation of the impaired contractility by modifying only one of the players important for the maintenance of calcium homeostasis.

In the present experiments, the improvement of contractility in failing cardiomyocytes overexpressing FKBP12.6 was most likely attributed to increased binding of FKBP12.6 to RyR2 upon overexpression, since considerably more FKBP12.6 was coimmunoprecipitated with RyR2 in transfected failing cardiomyocytes, in comparison with non-transfected failing cells (Fig. 35B). Moreover, the levels of exogenous FKBP12.6 associated with RyR2 exceeded the intrinsic levels of FKBP12.6 bound to RyR channels (Fig. 35B). This observation implies the availability of unsaturated FKBP12.6- 
binding sites on RyR2 in normal myocardium and suggests that overexpression is a justified approach to improve a function.

To elucidate whether FKBP overexpression really attenuates the abnormal calcium leak, leading consequently to improved contractile performance, analysis of $\mathrm{Ca}^{2+}$-transients and measurement of the SR $\mathrm{Ca}^{2+}$ content are planned.

The interpretation of the overexpression data addresses again the issue of PKA-dependent regulation of FKBP12.6-RyR2 association. Besides the observations that in failing heart RyR2 is hyperphosphorylated and PKA dissociates FKBP12.6 from RyR2, the group of Marks has shown in several studies that FKBP12.6 cannot bind to serine-2809-phosphorylated RyR2 or aspartate mutant (S2809D) of RyR2, which is thought to mimic phosphorylated RyR2 (Marx et al., 2000; Marx et al., 2001b; Wehrens et al., 2003). However, under our experimental conditions, we did observe reassociation of exogenous FKBP12.6 with RyR2, which might mean that either the extent of PKA phosphorylation of RyR2 is low or completely absent (the latter is consistent with the RyR2 phosphorylation data of the present study), enabling some excess FKBP12.6 to reassociate with RyR2, or PKA phosphorylation of RyR2 does not influence (even if it is present) FKBP12.6-RyR2 interaction. The observation of Xiao and co-workers, who showed that PKA phosphorylation of RyR2 at serine-2809 does not disrupt FKBP12.6-RyR2 interaction and that the S2809D mutant of RyR2 does not lose the ability to interact with FKBP12.6 (Xiao et al., 2004), supports the idea that PKA does not affect FKBP12.6-RyR2 interaction.

Considering the divergence of opinions with regard to regulation of RyR2-FKBP12.6 interaction, additional investigations are needed to gain a clearer insight of the mechanisms underlying the regulation of this interaction.

In conclusion, the important novel finding of this study, using a rabbit model of heart failure, is that overexpression of exogenous FKBP12.6 in failing cardiomyocytes restores, in part, their contractile function most probably due to retrieval of FKBP12.6-RyR2 association upon overexpression. This suggests that FKBP12.6 may represent a new molecular target for improvement of cardiac contractile performance in heart failure.

\subsection{Conclusions and future directions}

The present study has demonstrated that FKBP12 has significant effect on the contractility of rabbit cardiomyocytes. Interaction studies revealed that rabbit and human RyR2 interact with both FKBP12.6 and FKBP12, in contrast to canine RyR2 which is 
capable of interaction with FKBP12.6 exclusively. Taken together, this suggests, firstly, that in rabbit heart, FKBP12 is important to $\mathrm{Ca}^{2+}$ cycling and contractility. Secondly, that in both rabbit and human heart, FKBP12.6 is not the only isoform that interacts with RyR2.

The study in rabbit model of heart failure demonstrated that FKBP12.6-RyR2 binding is considerably reduced in rabbit failing heart. Furthermore, contractility of cardiomyocytes isolated from failing hearts is significantly decreased. Overexpression of exogenous FKBP12.6 in failing cardiomyocytes restores, in part, their contractile function as a consequence of increased association between FKBP12.6 and RyR2. These data indicate that rebinding of FKBP12.6 to RyR2 may represent a new therapeutical approach to the treatment of heart failure.

The present work provides the basis for further investigations of the role of FKBP12 in the regulation of $\mathrm{E}-\mathrm{C}$ coupling in the heart. To more fully define the functional relevance of FKBP to cardiac $\mathrm{Ca}^{2+}$ homeostasis, targeting of FKBP12 mRNA in rabbit cardiomyocytes by RNAi technique is planned. Selectivity of the RyR2 association with FKBP12.6 seems to be limited to the canine heart and attributed to the structural differences between canine cardiac RyR and cardiac RyR of other species. To clarify this finally, pinpointing the amino acid residues of canine RyR2 that determine its selective interaction with FKBP12.6 and that make it unable to interact with FKBP12 might be performed.

With regard to the study in rabbit heart failure model, it is planned to look into the mechanistic aspect of the positive inotropic effect of FKBP12.6 overexpression on contractility of failing cardiomyocytes. Therefore, analysis of $\mathrm{Ca}^{2+}$-transients and measurements of the SR $\mathrm{Ca}^{2+}$ content are intended. 


\section{REFERENCES}

1. Abraham R.T. and Wiederrecht G.J. Immunopharmacology of rapamycin. Annu.Rev.Immunol. 14: 483-510, 1996.

2. Arakawa H., Nagase H., Hayashi N., Fujiwara T., Ogawa M., Shin S., and Nakamura Y. Molecular cloning and expression of a novel human gene that is highly homologous to human FK506-binding protein 12kDa (hFKBP-12) and characterization of two alternatively spliced transcripts. Biochem.Biophys.Res.Commun. 200: 836-843, 1994.

3. Atkison P., Joubert G., Barron A., Grant D., Paradis K., Seidman E., Wall W., Rosenberg H., Howard J., Williams S., and . Hypertrophic cardiomyopathy associated with tacrolimus in paediatric transplant patients. Lancet. 345: 894-896, 1995.

4. Bandyopadhyay A., Shin D.W., Ahn J.O., and Kim D.H. Calcineurin regulates ryanodine receptor/Ca(2+)-release channels in rat heart. Biochem.J. 352 Pt 1: 61-70, 2000.

5. Barg S., Copello J.A., and Fleischer S. Different interactions of cardiac and skeletal muscle ryanodine receptors with FK-506 binding protein isoforms. Am.J.Physiol. 272: C1726-C1733, 1997.

6. Bassani R.A., Bassani J.W., and Bers D.M. Mitochondrial and sarcolemmal Ca2+ transport reduce [Ca2+]i during caffeine contractures in rabbit cardiac myocytes. J.Physiol. 453: 591-608, 1992.

7. Bers D.M. Cardiac excitation-contraction coupling. Nature. 415: 198-205, 2002.

8. Bers D.M. Excitation-Contraction Coupling and Cardiac Contractile Force. 2nd ed. Dordrecht, The Netherlands: Kluwer Academic Publishers, 2001: 1-427.

9. Beuckelmann D.J., Nabauer M., and Erdmann E. Intracellular calcium handling in isolated ventricular myocytes from patients with terminal heart failure. Circulation. 85: 1046-1055, 1992.

10. Blum H., Beier H., and Gross H.J. Improved silver staining of plant proteins, RNA and DNA in polyacrylamide gels. Electrophoresis. 8: 93-99, 1987.

11. Bohm M., Reiger B., Schwinger R.H., and Erdmann E. cAMP concentrations, cAMP dependent protein kinase activity, and phospholamban in non-failing and failing myocardium. Cardiovasc.Res. 28: 1713-1719, 1994.

12. Bram R.J., Hung D.T., Martin P.K., Schreiber S.L., and Crabtree G.R. Identification of the immunophilins capable of mediating inhibition of signal transduction by cyclosporin A and FK506: roles of calcineurin binding and cellular location. Mol.Cell Biol. 13: 4760-4769, 1993.

13. Brillantes A.B., Ondrias K., Scott A., Kobrinsky E., Ondriasova E., Moschella M.C., Jayaraman T., Landers M., Ehrlich B.E., and Marks A.R. Stabilization of calcium release channel (ryanodine receptor) function by FK506-binding protein. Cell. 77: 513-523, 1994.

14. Bristow M.R., Minobe W., Rasmussen R., Larrabee P., Skerl L., Klein J.W., Anderson F.L., Murray J., Mestroni L., Karwande S.V., and . Beta-adrenergic neuroeffector 
abnormalities in the failing human heart are produced by local rather than systemic mechanisms. J.Clin.Invest. 89: 803-815, 1992.

15. Bultynck G., De Smet P., Rossi D., Callewaert G., Missiaen L., Sorrentino V., De Smedt H., and Parys J.B. Characterization and mapping of the $12 \mathrm{kDa}$ FK506binding protein (FKBP12)-binding site on different isoforms of the ryanodine receptor and of the inositol 1,4,5-trisphosphate receptor. Biochem.J. 354: 413-422, 2001a.

16. Bultynck G., Rossi D., Callewaert G., Missiaen L., Sorrentino V., Parys J.B., and De Smedt H. The conserved sites for the FK506-binding proteins in ryanodine receptors and inositol 1,4,5-trisphosphate receptors are structurally and functionally different. J.Biol.Chem. 276: 47715-47724, 2001b.

17. Cameron A.M., Nucifora F.C., Jr., Fung E.T., Livingston D.J., Aldape R.A., Ross C.A., and Snyder S.H. FKBP12 binds the inositol 1,4,5-trisphosphate receptor at leucine-proline (1400-1401) and anchors calcineurin to this FK506-like domain. J.Biol.Chem. 272: 27582-27588, 1997.

18. Collins J.H. Sequence analysis of the ryanodine receptor: possible association with a 12K, FK506-binding immunophilin/protein kinase C inhibitor. Biochem.Biophys.Res.Commun. 178: 1288-1290, 1991.

19. Cory C.R., McCutcheon L.J., O'Grady M., Pang A.W., Geiger J.D., and O'Brien P.J. Compensatory downregulation of myocardial $\mathrm{Ca}$ channel in SR from dogs with heart failure. Am.J.Physiol. 264: H926-H937, 1993.

20. Dipla K., Mattiello J.A., Margulies K.B., Jeevanandam V., and Houser S.R. The sarcoplasmic reticulum and the $\mathrm{Na}+\mathrm{Ca} 2+$ exchanger both contribute to the $\mathrm{Ca} 2+$ transient of failing human ventricular myocytes. Circ.Res. 84: 435-444, 1999.

21. duBell W.H., Wright P.A., Lederer W.J., and Rogers T.B. Effect of the immunosupressant FK506 on excitation-contraction coupling and outward $\mathrm{K}+$ currents in rat ventricular myocytes. J.Physiol. 501 ( Pt 3): 509-516, 1997.

22. Flanagan W.M., Corthesy B., Bram R.J., and Crabtree G.R. Nuclear association of a Tcell transcription factor blocked by FK-506 and cyclosporin A. Nature. 352: 803807, 1991.

23. Fulton K.F., Jackson S.E., and Buckle A.M. Energetic and structural analysis of the role of tryptophan 59 in FKBP12. Biochemistry. 42: 2364-2372, 2003.

24. Gaburjakova M., Gaburjakova J., Reiken S., Huang F., Marx S.O., Rosemblit N., and Marks A.R. FKBP12 binding modulates ryanodine receptor channel gating. J.Biol.Chem. 276: 16931-16935, 2001.

25. George C.H., Higgs G.V., and Lai F.A. Ryanodine receptor mutations associated with stress-induced ventricular tachycardia mediate increased calcium release in stimulated cardiomyocytes. Circ.Res. 93: 531-540, 2003.

26. Go L.O., Moschella M.C., Watras J., Handa K.K., Fyfe B.S., and Marks A.R. Differential regulation of two types of intracellular calcium release channels during end-stage heart failure. J.Clin.Invest. 95: 888-894, 1995.

27. Gomez A.M., Valdivia H.H., Cheng H., Lederer M.R., Santana L.F., Cannell M.B., McCune S.A., Altschuld R.A., and Lederer W.J. Defective excitation-contraction coupling in experimental cardiac hypertrophy and heart failure. Science. 276: 800806, 1997. 
28. Hasenfuss G. Alterations of calcium-regulatory proteins in heart failure. Cardiovasc.Res. 37: 279-289, 1998.

29. Hasenfuss G. and Seidler T. Treatment of heart failure through stabilization of the cardiac ryanodine receptor. Circulation. 107: 378-380, 2003.

30. Hobai I.A. and O'Rourke B. Enhanced $\mathrm{Ca}(2+)$-activated $\mathrm{Na}(+)-\mathrm{Ca}(2+)$ exchange activity in canine pacing-induced heart failure. Circ.Res. 87: 690-698, 2000.

31. Houser S.R., Piacentino V., III, and Weisser J. Abnormalities of calcium cycling in the hypertrophied and failing heart. J.Mol.Cell Cardiol. 32: 1595-1607, 2000.

32. Inui M., Saito A., and Fleischer S. Isolation of the ryanodine receptor from cardiac sarcoplasmic reticulum and identity with the feet structures. J.Biol.Chem. 262: 15637-15642, 1987a.

33. Inui M., Saito A., and Fleischer S. Purification of the ryanodine receptor and identity with feet structures of junctional terminal cisternae of sarcoplasmic reticulum from fast skeletal muscle. J.Biol.Chem. 262: 1740-1747, 1987b.

34. Jain A., Mazariegos G., Kashyap R., Green M., Gronsky C., Starzl T.E., Fung J., and Reyes J. Comparative long-term evaluation of tacrolimus and cyclosporine in pediatric liver transplantation. Transplantation. 70: 617-625, 2000.

35. Jayaraman T., Brillantes A.M., Timerman A.P., Fleischer S., Erdjument-Bromage H., Tempst P., and Marks A.R. FK506 binding protein associated with the calcium release channel (ryanodine receptor). J.Biol.Chem. 267: 9474-9477, 1992.

36. Jeyakumar L.H., Ballester L., Cheng D.S., Mclntyre J.O., Chang P., Olivey H.E., Rollins-Smith L., Barnett J.V., Murray K., Xin H.B., and Fleischer S. FKBP binding characteristics of cardiac microsomes from diverse vertebrates. Biochem.Biophys.Res.Commun. 281: 979-986, 2001.

37. Jiang M.T., Lokuta A.J., Farrell E.F., Wolff M.R., Haworth R.A., and Valdivia H.H. Abnormal $\mathrm{Ca} 2+$ release, but normal ryanodine receptors, in canine and human heart failure. Circ.Res. 91: 1015-1022, 2002.

38. Kaftan E., Marks A.R., and Ehrlich B.E. Effects of rapamycin on ryanodine receptor/Ca(2+)-release channels from cardiac muscle. Circ.Res. 78: 990-997, 1996.

39. Kirchhefer U., Schmitz W., Scholz H., and Neumann J. Activity of cAMP-dependent protein kinase and $\mathrm{Ca} 2+/$ calmodulin-dependent protein kinase in failing and nonfailing human hearts. Cardiovasc.Res. 42: 254-261, 1999.

40. Laemmli U.K. Cleavage of structural proteins during the assembly of the head of bacteriophage T4. Nature. 227: 680-685, 1970.

41. Lai F.A., Erickson H.P., Rousseau E., Liu Q.Y., and Meissner G. Purification and reconstitution of the calcium release channel from skeletal muscle. Nature. 331: 315-319, 1988.

42. Lai F.A., Misra M., Xu L., Smith H.A., and Meissner G. The ryanodine receptor-Ca2+ release channel complex of skeletal muscle sarcoplasmic reticulum. Evidence for a cooperatively coupled, negatively charged homotetramer. J.Biol.Chem. 264: 16776-16785, 1989. 
43. Lam E., Martin M.M., Timerman A.P., Sabers C., Fleischer S., Lukas T., Abraham R.T., O'Keefe S.J., O'Neill E.A., and Wiederrecht G.J. A novel FK506 binding protein can mediate the immunosuppressive effects of FK506 and is associated with the cardiac ryanodine receptor. J.Biol.Chem. 270: 26511-26522, 1995.

44. Li Y., Kranias E.G., Mignery G.A., and Bers D.M. Protein kinase A phosphorylation of the ryanodine receptor does not affect calcium sparks in mouse ventricular myocytes. Circ.Res. 90: 309-316, 2002.

45. Lindsay A.R. and Williams A.J. Functional characterisation of the ryanodine receptor purified from sheep cardiac muscle sarcoplasmic reticulum. Biochim.Biophys.Acta. 1064: 89-102, 1991.

46. Liu J., Farmer J.D., Jr., Lane W.S., Friedman J., Weissman I., and Schreiber S.L. Calcineurin is a common target of cyclophilin-cyclosporin A and FKBP-FK506 complexes. Cell. 66: 807-815, 1991.

47. Lokuta A.J., Meyers M.B., Sander P.R., Fishman G.I., and Valdivia H.H. Modulation of cardiac ryanodine receptors by sorcin. J.Biol.Chem. 272: 25333-25338, 1997.

48. Mackrill J.J. Protein-protein interactions in intracellular Ca2+-release channel function. Biochem.J. 337 ( Pt 3): 345-361, 1999.

49. Marks A.R. Cardiac intracellular calcium release channels: role in heart failure. Circ.Res. 87: 8-11, 2000.

50. Marks A.R. Ryanodine receptors/calcium release channels in heart failure and sudden cardiac death. J.Mol.Cell Cardiol. 33: 615-624, 2001.

51. Marx S.O., Gaburjakova J., Gaburjakova M., Henrikson C., Ondrias K., and Marks A.R. Coupled gating between cardiac calcium release channels (ryanodine receptors). Circ.Res. 88: 1151-1158, 2001a.

52. Marx S.O. and Marks A.R. Regulation of the ryanodine receptor in heart failure. Basic Res. Cardiol. 97 Suppl 1: 149-151, 2002.

53. Marx S.O., Ondrias K., and Marks A.R. Coupled gating between individual skeletal muscle Ca2+ release channels (ryanodine receptors). Science. 281: 818-821, 1998.

54. Marx S.O., Reiken S., Hisamatsu Y., Gaburjakova M., Gaburjakova J., Yang Y.M., Rosemblit N., and Marks A.R. Phosphorylation-dependent regulation of ryanodine receptors: a novel role for leucine/isoleucine zippers. J.Cell Biol. 153: 699-708, 2001b.

55. Marx S.O., Reiken S., Hisamatsu Y., Jayaraman T., Burkhoff D., Rosemblit N., and Marks A.R. PKA phosphorylation dissociates FKBP12.6 from the calcium release channel (ryanodine receptor): defective regulation in failing hearts. Cell. 101: 365376, 2000.

56. Masumiya H., Wang R., Zhang J., Xiao B., and Chen S.R. Localization of the 12.6-kDa FK506-binding protein (FKBP12.6) binding site to the NH2-terminal domain of the cardiac Ca2+ release channel (ryanodine receptor). J.Biol.Chem. 278: 3786-3792, 2003.

57. McCall E., Li L., Satoh H., Shannon T.R., Blatter L.A., and Bers D.M. Effects of FK-506 on contraction and $\mathrm{Ca} 2+$ transients in rat cardiac myocytes. Circ.Res. 79: 1110$1121,1996$. 
58. Meissner G. Ryanodine activation and inhibition of the Ca2+ release channel of sarcoplasmic reticulum. J.Biol.Chem. 261: 6300-6306, 1986.

59. Munch G., Bolck B., Sugaru A., Brixius K., Bloch W., and Schwinger R.H. Increased expression of isoform 1 of the sarcoplasmic reticulum $\mathrm{Ca}(2+)$-release channel in failing human heart. Circulation. 103: 2739-2744, 2001.

60. Munch G., Bolck B., Sugaru A., and Schwinger R.H. Isoform expression of the sarcoplasmic reticulum $\mathrm{Ca} 2+$ release channel (ryanodine channel) in human myocardium. J.Mol.Med. 78: 352-360, 2000.

61. Nakai J., Imagawa T., Hakamat Y., Shigekawa M., Takeshima H., and Numa S. Primary structure and functional expression from cDNA of the cardiac ryanodine receptor/calcium release channel. FEBS Lett. 271: 169-177, 1990.

62. Neumann J., Eschenhagen T., Jones L.R., Linck B., Schmitz W., Scholz H., and Zimmermann N. Increased expression of cardiac phosphatases in patients with end-stage heart failure. J.Mol.Cell Cardiol. 29: 265-272, 1997.

63. Noguchi N., Takasawa S., Nata K., Tohgo A., Kato I., Ikehata F., Yonekura H., and Okamoto H. Cyclic ADP-ribose binds to FK506-binding protein 12.6 to release Ca2+ from islet microsomes. J.Biol.Chem. 272: 3133-3136, 1997.

64. O'Brien P.J., Moe G.W., Nowack L.M., Grima E.A., and Armstrong P.W. Sarcoplasmic reticulum Ca-release channel and ATP-synthesis activities are early myocardial markers of heart failure produced by rapid ventricular pacing in dogs. Can.J.Physiol Pharmacol. 72: 999-1006, 1994.

65. O'Rourke B., Kass D.A., Tomaselli G.F., Kaab S., Tunin R., and Marban E. Mechanisms of altered excitation-contraction coupling in canine tachycardiainduced heart failure, I: experimental studies. Circ.Res. 84: 562-570, 1999.

66. Otsu K., Willard H.F., Khanna V.K., Zorzato F., Green N.M., and MacLennan D.H. Molecular cloning of cDNA encoding the $\mathrm{Ca} 2+$ release channel (ryanodine receptor) of rabbit cardiac muscle sarcoplasmic reticulum. J.Biol.Chem. 265: 13472-13483, 1990.

67. Pieske B., Maier L.S., Bers D.M., and Hasenfuss G. Ca2+ handling and sarcoplasmic reticulum $\mathrm{Ca} 2+$ content in isolated failing and nonfailing human myocardium. Circ.Res. 85: 38-46, 1999.

68. Prestle J., Janssen P.M., Janssen A.P., Zeitz O., Lehnart S.E., Bruce L., Smith G.L., and Hasenfuss G. Overexpression of FK506-binding protein FKBP12.6 in cardiomyocytes reduces ryanodine receptor-mediated $\mathrm{Ca}(2+)$ leak from the sarcoplasmic reticulum and increases contractility. Circ.Res. 88: 188-194, 2001.

69. Prestle J., Janssen P.M.L., Janssen A., and Hasenfuss G. Overexpression of FKBP12.6 to influence SR function. In: Hasenfuss G. and Marban E. ed. Molecular Approaches to Heart Failure Therapy. Darmstadt, Germany: Steinkopff Verlag, 2000: 89-99.

70. Protasi F., Franzini-Armstrong C., and Allen P.D. Role of ryanodine receptors in the assembly of calcium release units in skeletal muscle. J.Cell Biol. 140: 831-842, 1998.

71. Qi Y., Ogunbunmi E.M., Freund E.A., Timerman A.P., and Fleischer S. FK-binding protein is associated with the ryanodine receptor of skeletal muscle in vertebrate animals. J.Biol.Chem. 273: 34813-34819, 1998. 
72. Regitz-Zagrosek V., Hertrampf R., Steffen C., Hildebrandt A., and Fleck E. Myocardial cyclic AMP and norepinephrine content in human heart failure. Eur.Heart J. 15 Suppl D: 7-13, 1994.

73. Reiken S., Gaburjakova M., Gaburjakova J., He KI K.L., Prieto A., Becker E., Yi Gh G.H., Wang J., Burkhoff D., and Marks A.R. beta-adrenergic receptor blockers restore cardiac calcium release channel (ryanodine receptor) structure and function in heart failure. Circulation. 104: 2843-2848, 2001.

74. Reiken S., Wehrens X.H., Vest J.A., Barbone A., Klotz S., Mancini D., Burkhoff D., and Marks A.R. Beta-blockers restore calcium release channel function and improve cardiac muscle performance in human heart failure. Circulation. 107: 2459-2466, 2003.

75. Rodriguez P., Bhogal M.S., and Colyer J. Stoichiometric phosphorylation of cardiac ryanodine receptor on serine 2809 by calmodulin-dependent kinase II and protein kinase A. J.Biol.Chem. 278: 38593-38600, 2003.

76. Rust E.M., Westfall M.V., and Metzger J.M. Stability of the contractile assembly and $\mathrm{Ca} 2+-a c t i v a t e d$ tension in adenovirus infected adult cardiac myocytes. Mol.Cell Biochem. 181: 143-155, 1998.

77. Samso M. and Wagenknecht T. Contributions of electron microscopy and single-particle techniques to the determination of the ryanodine receptor three-dimensional structure. J.Struct.Biol. 121: 172-180, 1998.

78. Schreiber S.L. Chemistry and biology of the immunophilins and their immunosuppressive ligands. Science. 251: 283-287, 1991.

79. Sewell T.J., Lam E., Martin M.M., Leszyk J., Weidner J., Calaycay J., Griffin P., Williams H., Hung S., Cryan J., and . Inhibition of calcineurin by a novel FK-506binding protein. J.Biol.Chem. 269: 21094-21102, 1994.

80. Shoshan-Barmatz V. and Zarka A. A simple, fast, one-step method for the purification of the skeletal-muscle ryanodine receptor. Biochem.J. 285 ( Pt 1): 61-64, 1992.

81. Shou W., Aghdasi B., Armstrong D.L., Guo Q., Bao S., Charng M.J., Mathews L.M., Schneider M.D., Hamilton S.L., and Matzuk M.M. Cardiac defects and altered ryanodine receptor function in mice lacking FKBP12. Nature. 391: 489-492, 1998.

82. Siekierka J.J., Wiederrecht G., Greulich H., Boulton D., Hung S.H., Cryan J., Hodges P.J., and Sigal N.H. The cytosolic-binding protein for the immunosuppressant FK506 is both a ubiquitous and highly conserved peptidyl-prolyl cis-trans isomerase. J.Biol.Chem. 265: 21011-21015, 1990.

83. Sorrentino V. and Volpe P. Ryanodine receptors: how many, where and why? Trends Pharmacol.Sci. 14: 98-103, 1993.

84. Takeshima H., Nishimura S., Matsumoto T., Ishida H., Kangawa K., Minamino N., Matsuo H., Ueda M., Hanaoka M., Hirose T., and . Primary structure and expression from complementary DNA of skeletal muscle ryanodine receptor. Nature. 339: 439-445, 1989.

85. Terentyev D., Viatchenko-Karpinski S., Gyorke I., Terentyeva R., and Gyorke S. Protein phosphatases decrease sarcoplasmic reticulum calcium content by stimulating calcium release in cardiac myocytes. J.Physiol. 552: 109-118, 2003. 
86. Timerman A.P., Jayaraman T., Wiederrecht G., Onoue H., Marks A.R., and Fleischer S. The ryanodine receptor from canine heart sarcoplasmic reticulum is associated with a novel FK-506 binding protein. Biochem.Biophys.Res.Commun. 198: 701706, 1994.

87. Timerman A.P., Ogunbumni E., Freund E., Wiederrecht G., Marks A.R., and Fleischer S. The calcium release channel of sarcoplasmic reticulum is modulated by FK-506binding protein. Dissociation and reconstitution of FKBP-12 to the calcium release channel of skeletal muscle sarcoplasmic reticulum. J.Biol.Chem. 268: 2299222999, 1993.

88. Timerman A.P., Onoue H., Xin H.B., Barg S., Copello J., Wiederrecht G., and Fleischer S. Selective binding of FKBP12.6 by the cardiac ryanodine receptor. J.Biol.Chem. 271: 20385-20391, 1996.

89. Timerman A.P., Wiederrecht G., Marcy A., and Fleischer S. Characterization of an exchange reaction between soluble FKBP-12 and the FKBP.ryanodine receptor complex. Modulation by FKBP mutants deficient in peptidyl-prolyl isomerase activity. J.Biol.Chem. 270: 2451-2459, 1995.

90. Towbin H., Staehelin T., and Gordon J. Electrophoretic transfer of proteins from polyacrylamide gels to nitrocellulose sheets: procedure and some applications. Proc.Natl.Acad.Sci.U.S.A. 76: 4350-4354, 1979.

91. Wagenknecht T., Berkowitz J., Grassucci R., Timerman A.P., and Fleischer S. Localization of calmodulin binding sites on the ryanodine receptor from skeletal muscle by electron microscopy. Biophys.J. 67: 2286-2295, 1994.

92. Wagenknecht T., Grassucci R., Berkowitz J., Wiederrecht G.J., Xin H.B., and Fleischer S. Cryoelectron microscopy resolves FK506-binding protein sites on the skeletal muscle ryanodine receptor. Biophys.J. 70: 1709-1715, 1996.

93. Wagenknecht T., Grassucci R., Frank J., Saito A., Inui M., and Fleischer S. Threedimensional architecture of the calcium channel/foot structure of sarcoplasmic reticulum. Nature. 338: 167-170, 1989.

94. Wagenknecht T., Radermacher M., Grassucci R., Berkowitz J., Xin H.B., and Fleischer S. Locations of calmodulin and FK506-binding protein on the threedimensional architecture of the skeletal muscle ryanodine receptor. J.Biol.Chem. 272: 32463-32471, 1997.

95. Wang T., Li B.Y., Danielson P.D., Shah P.C., Rockwell S., Lechleider R.J., Martin J., Manganaro T., and Donahoe P.K. The immunophilin FKBP12 functions as a common inhibitor of the TGF beta family type I receptors. Cell. 86: 435-444, 1996.

96. Wehrens X.H., Lehnart S.E., Huang F., Vest J.A., Reiken S.R., Mohler P.J., Sun J., Guatimosim S., Song L.S., Rosemblit N., D'Armiento J.M., Napolitano C., Memmi M., Priori S.G., Lederer W.J., and Marks A.R. FKBP12.6 deficiency and defective calcium release channel (ryanodine receptor) function linked to exerciseinduced sudden cardiac death. Cell. 113: 829-840, 2003.

97. Witcher D.R., Kovacs R.J., Schulman H., Cefali D.C., and Jones L.R. Unique phosphorylation site on the cardiac ryanodine receptor regulates calcium channel activity. J.Biol.Chem. 266: 11144-11152, 1991.

98. Xiao B., Sutherland C., Walsh M.P., and Chen S.R. Protein kinase A phosphorylation at serine-2808 of the cardiac Ca2+-release channel (ryanodine receptor) does not 
dissociate 12.6-kDa FK506-binding protein (FKBP12.6). Circ.Res. 94: 487-495, 2004.

99. Xiao R.P., Valdivia H.H., Bogdanov K., Valdivia C., Lakatta E.G., and Cheng H. The immunophilin FK506-binding protein modulates $\mathrm{Ca} 2+$ release channel closure in rat heart. J.Physiol. 500 ( Pt 2): 343-354, 1997.

100. Xin H.B., Rogers K., Qi Y., Kanematsu T., and Fleischer S. Three amino acid residues determine selective binding of FK506-binding protein 12.6 to the cardiac ryanodine receptor. J.Biol.Chem. 274: 15315-15319, 1999.

101. Xin H.B., Senbonmatsu T., Cheng D.S., Wang Y.X., Copello J.A., Ji G.J., Collier M.L., Deng K.Y., Jeyakumar L.H., Magnuson M.A., Inagami T., Kotlikoff M.I., and Fleischer S. Oestrogen protects FKBP12.6 null mice from cardiac hypertrophy. Nature. 416: 334-338, 2002.

102. Xin H.B., Timerman A.P., Onoue H., Wiederrecht G.J., and Fleischer S. Affinity purification of the ryanodine receptor/calcium release channel from fast twitch skeletal muscle based on its tight association with FKBP12. Biochem.Biophys.Res.Commun. 214: 263-270, 1995.

103. Yano M., Kobayashi S., Kohno M., Doi M., Tokuhisa T., Okuda S., Suetsugu M., Hisaoka T., Obayashi M., Ohkusa T., Kohno M., and Matsuzaki M. FKBP12.6mediated stabilization of calcium-release channel (ryanodine receptor) as a novel therapeutic strategy against heart failure. Circulation. 107: 477-484, 2003.

104. Yano M., Ono K., Ohkusa T., Suetsugu M., Kohno M., Hisaoka T., Kobayashi S., Hisamatsu Y., Yamamoto T., Kohno M., Noguchi N., Takasawa S., Okamoto H., and Matsuzaki M. Altered stoichiometry of FKBP12.6 versus ryanodine receptor as a cause of abnormal $\mathrm{Ca}(2+)$ leak through ryanodine receptor in heart failure. Circulation. 102: 2131-2136, 2000.

105. Yin C.C. and Lai F.A. Intrinsic lattice formation by the ryanodine receptor calcium-release channel. Nat.Cell Biol. 2: 669-671, 2000.

106. Zhang J., Liu Z., Masumiya H., Wang R., Jiang D., Li F., Wagenknecht T., and Chen S.R. Three-dimensional localization of divergent region 3 of the ryanodine receptor to the clamp-shaped structures adjacent to the FKBP binding sites. J.Biol.Chem. 278: 14211-14218, 2003.

107. Zhang L., Kelley J., Schmeisser G., Kobayashi Y.M., and Jones L.R. Complex formation between junctin, triadin, calsequestrin, and the ryanodine receptor. Proteins of the cardiac junctional sarcoplasmic reticulum membrane. J.Biol.Chem. 272: 23389-23397, 1997.

108. Zhao M., Li P., Li X., Zhang L., Winkfein R.J., and Chen S.R. Molecular identification of the ryanodine receptor pore-forming segment. J.Biol.Chem. 274: 25971-25974, 1999. 


\section{Acknowledgements}

I want to express gratitude to Professor Gerd Hasenfuss for the opportunity he gave me to work in this department and for his encouragement to perform this study.

I am thankful to Professor Kurt von Figura for reviewing my PhD thesis and to Professor Dieter Heineke for being my coreviewer.

I am very grateful to Professor Gerhard Burckhardt, a leader of GRK 335, for giving me the opportunity to be a scholar in the frame of GRK "Clinical, Cellular and Molecular Biology of Internal Organs" and for his warm encouragement and help in every respect.

I thank Dr. Tim Seidler for his support and supervision.

I am grateful to Dr. Wolfgang Schillinger, Nils Teucher and Claus Christians for their tremendous work on generation of animal model of heart failure.

My sincere thanks to Dr. Phuc van Nguyen for his cooperation, practical advices, patient answering my questions and for every kind of support.

I appreciate the help and cooperation of Dr. Lars Maier, who provide me the precious anti-ryanodine receptor antibodies.

I want to give my special thanks to Lisa Barski, from whom I learnt the best laboratory practice, for her help in my work.

I appreciate contribution of Dr. Harald Kögler and Dr. Kaomei Guan to my project by helpful advices and discussions.

I thank Dr. Hassan Dihazi and Silke Singer for performing mass spectrometry analysis of my samples.

I am thankful to Dr. Rebecca Fritz for proof-read and stylistic corrections of the manuscript.

I am thankful to Michael Kothe for the huge yields of the isolated cardiomyocytes and for isolations of precious cardiomyocytes from failing hearts.

Owing to logistical talent of Sandra Ott-Gebauer and Jessica Spitalieri, everything needed for my work was always at the hand.

I thank all my colleagues, with whom I worked side by side and day by day in the department, for the creation of scientific working atmosphere.

My very special thanks I give to you, Kirill, for your wholehearted and active support, patience and understanding. Also I thank you for help in computer design of this work.

Finally, I want to give a very special thanks to my mother and uncle for their moral support that was so necessary for me during this whole period. 


\title{
Curriculum Vitae
}

\author{
Name Darya Zibrova \\ Date of birth \\ 1.12.1977 \\ Place of birth Kremenchug \\ Citizenship Ukraine \\ $1985-1995 \quad$ School education \\ Ukraine \\ $1995-2000 \quad$ University Study \\ Biological faculty \\ Kiev National Taras Shevchenco University \\ Kiev, Ukraine \\ 1999 \\ Bachelor diploma with honors \\ Degree: Bachelor of Science in biology, teacher of biology \\ Defense of Bachelor scientific project "Identification and \\ characterization of $\lg G$ to streptokinase" \\ Master diploma with honors \\ Degree: Master of Science in biology, microbiology and \\ virology with specialization in immunology, University teacher \\ of biology \\ Defense of Master scientific project "Purification of \\ topoisomerase I and its investigation as autoantigen in \\ thyroid cancer" \\ $2000-2001$ \\ PhD Student \\ Department of structure and function of nucleic acids \\ Institute of Molecular Biology and Genetics \\ National Academy of Science \\ Kiev, Ukraine
}

March 2001 - March Experimental work for the present dissertation in Department 2004

of Cardiology and Pneumology of Georg-August University Clinic (Göttingen) in the frame of GRK 335 "Clinical, Cellular and Molecular Biology of Internal Organs" 